\title{
A COLONY \\ IN THE MAKING
}

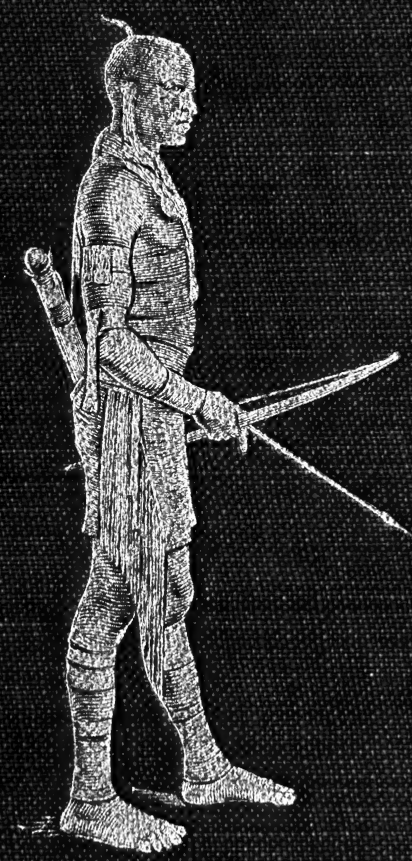

BY I,ORD ORANWORTII 


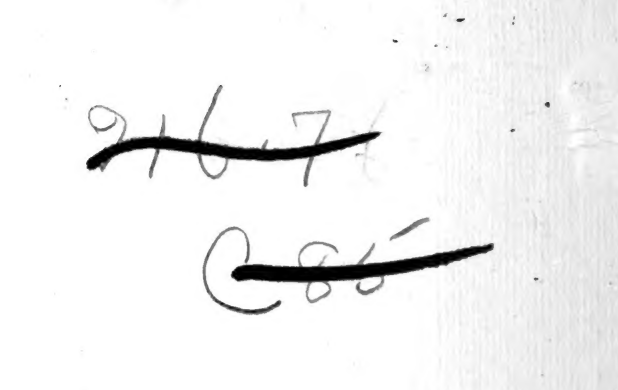




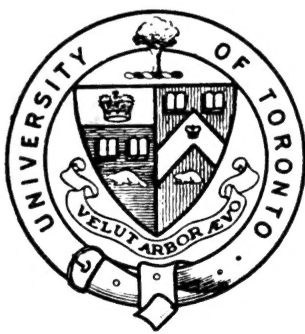

Presented to the

UNIVERSITY OF TORONTO

LIBRARY

by the

ONTARIO LEGISLATIVE

LIBRARY

1980 
Digitized by the Internet Archive in 2008 with funding from Microsoft Corporation 
A COLONY IN THE MAKING 


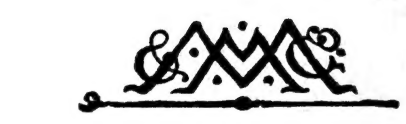

MACMILLAN AND CO., LIMITED

LONDON . BOMBAY . CALCUTTA MELBOURNE

THE MACMILLAN COMPANY

NEW YORK - BOSTON - CHICAGO

DALLAS . SAN FRANCISCO

THE MACMILLAN CO. OF CANADA. L'Td. TORONTO 
(

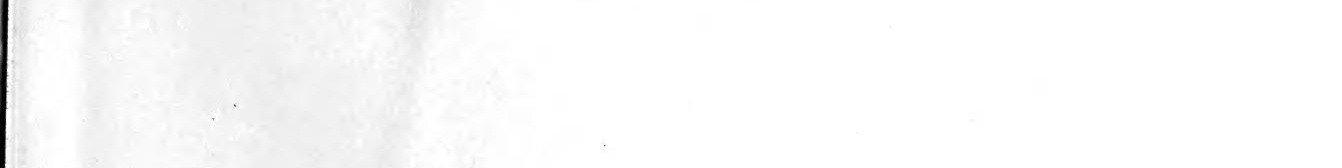




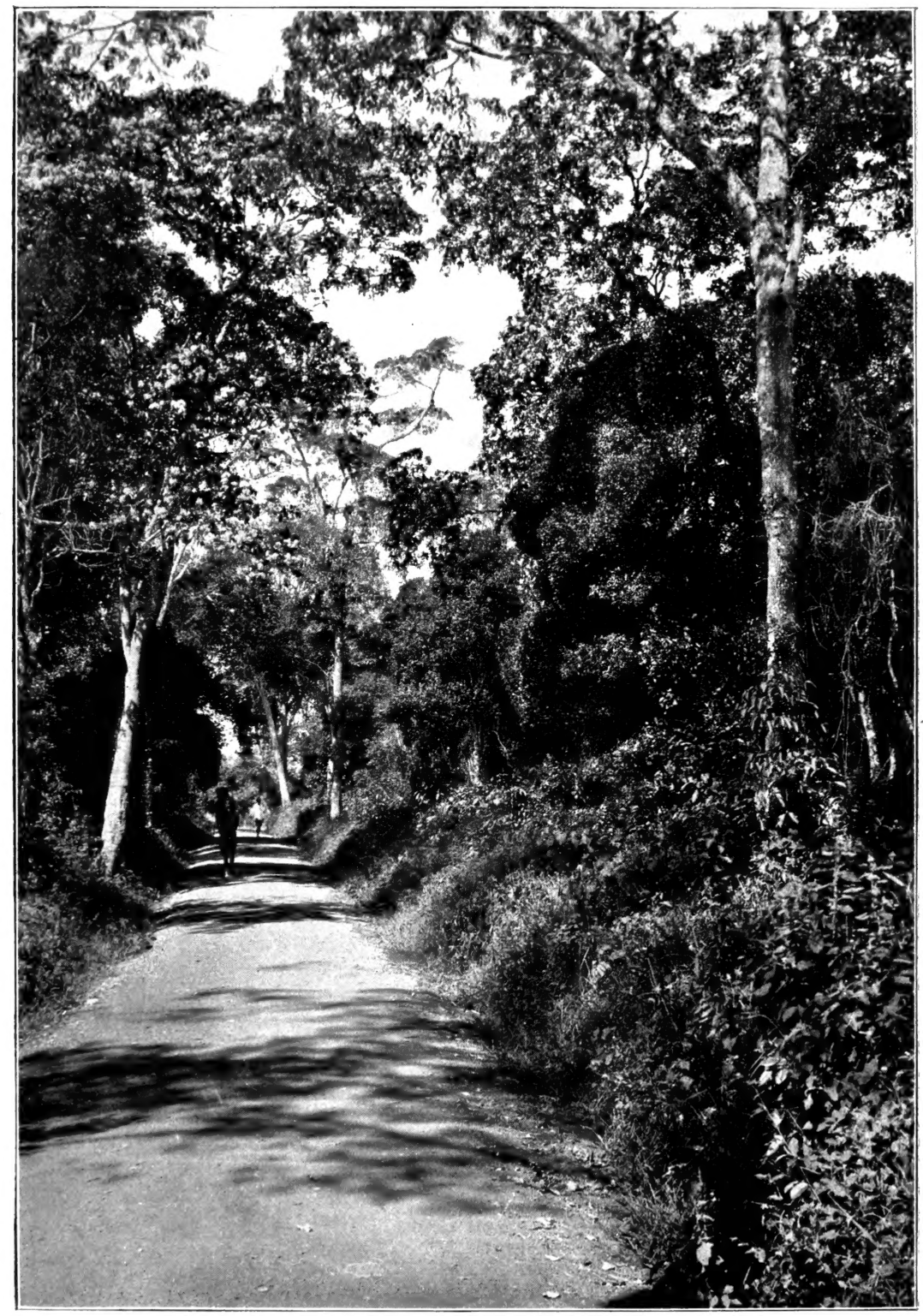

Fron NaIrobi to Kikuyu.

Photoby R. J. Stordy. 
$3110 \%$

A COLONY IN THE MAKING . Or SPORT AND PROFIT IN BRITISH EAST AFRICA By LORD CRANWORTH

WITH MAP AND ILLUSTRATIONS

MACMILLAN AND CO., LIMITED ST. MARTIN'S STREET, LONDON 

TO

LORD DELAMERE

WHO HAS ATTEMPTED AND EFFECTED AS MUCH AS ANY TWO other men For the Good of the Protectorate AND TO

LADY DELAMERE

WHO HAS SHARED HIS WORK AND BRIGHTENED THE PATH OF ALL WHO HAVE MET HER 



\section{PREFACE}

IN producing this small work I am not unmindful of the vast stream of literature that has issued from and flowed about the small Protectorate of British East Africa. I am, however, induced to add one more drop to this volume by the reflection that the great proportion of that stream is tinged by, if indeed not mainly composed of, the blood of slain animals, and that there is not very much recent matter which will afford information, even of the roughest kind, as to the life and opportunities which will await the intending Settler.

This, then, is my hope ; that some slight idea may be obtained herein of the climate, of the sport, of the possibilities of gain and recreation in the Highlands of East Africa.

For many years an ever-increasing body of men, at whose head stands Lord Delamere, have been striving to prove to a sceptical and very faintly interested public that these Highlands of the Protectorate offer the chance of the addition of yet another Colony, small but eminently prosperous, to the Empire. The last year or two has shown that their efforts and sacrifice have not been made in vain.

I hope that my readers will bear in mind two points- 
Firstly, that anything here written applies only to those portions of the Protectorate which are or can be suitable for the permanent home of a white race; secondly, that it is only applicable or approximately correct as up to the end of I9I I. I would like to take this opportunity of returning thanks for all the very great kindness and hospitality I have received while in the country, and to express a hope that the feelings of no inhabitant thereof mentioned in this book may be injured. If any such injury is inflicted I can only say that the laceration is absolutely unintentional, and express my most sincere apologies.

It is quite impossible for me to express adequately my thanks to the numerous people who have directly or indirectly helped me in this publication. To the following among them I owe special acknowledgment; to my wife, to the head of each department and many other officials, to Mr. F. J. Jackson, C.B., C.M.G., Lord Delamere, Mr. A. H. Tompson, Colonel Owen Thomas, Mr. A. Lambert, Mr. J. Stirling, Mr. J. W. Milligan, Mr. H. F. Ward, Mr. R. B. Woosnam, Mr. A. Herz, Colonel Ward, Captain Brown and many others, and not least to Mr. H. J. Read, of the Colonial Office, for his kindness in giving free access to books of reference. The photographs by Mr. R. J. Stordy speak for themselves, and if this work has any merit the main portion of it is due to them. 


\section{CONTENTS}

CHAPTER I

INTRODUCTORY .

PAGE

CHAPTER I

CHAPTER II

RELATING TO HEALTH AND CLIMATE

10

CHAPTER III

RACES AND CLASSES

CHAPTER IV

THE MASAI .

CHAPTER V

THE KIKUYU

CHAPTER VI

THE INDIAN POPULATION

60

CHAPTER VII

THE SWAHILI AND THE SOMALI.

CHAPTER VIII

SETTLERS AND OFFICIALS 75

CHAPTER IX

HINTS FOR A WOMAN IN BRITISH EAST AFRICA. By Lady Cranworth 
CHAPTER XI

AGRICULTURAL PROSPECTS

CHAPTER XII

SISAL HEMP AND BLACK WATTLE

CHAPTER XIII

WHEAT, MAIZE, COFFEE .

\section{CHAPTER XIV}

PIGS, CATTLE, OSTRICHES

CHAPTER XV

SHEEP

CHAPTER XVI

FORESTS

CHAPTER XVII

LABOUR

CHAPTER XVIII

MINERALS

CHAPTER XIX

TYPE OF SETTLER REQUIRED

CHAPTER XX

THE UGANDA RAILWAY

\section{CHAPTER XXI}


CHAPTER XXII

LOCAL POLITICS

\section{CHAPTER XXIII}

EDUCATION

\section{CHAPTER XXIV}

BIG GAME SHOOTING

\section{CHAPTER XXV}

THE GAME ANIMALS OF THE PROTECTORATE.

\section{CHAPTER XXVI}

ANIMALS WHICH PROVIDE SPORT

CHAPTER XXVII

ANIMALS WHICH PROVIDE MEAT OR HIDES 265

\section{CHAPTER XXVIII}

THE BLACK LIST 275

CHAPTER XXIX

ANIMALS OF THE BACK BLOCKS 282

\section{CHAPTER XXX}

GAME BIRDS FOR SPORT AND FOR THE POT

CHAPTER XXXI

GAME RESERVES

\section{CHAPTER XXXII}

FISHING

\section{CHAPTER XXXIII}

HORSE RACING, HUNTING AND POLO . 


\section{CHAPTER XXXIV}

CRICKET, FOOTBALL, LAWN-TENNIS, GOLF, AND HOCKEY $\cdots \quad . \quad 336$

APPENDICES :
A . 345
B. . . . . . . . . 346
C. . . . . . . . . . 346
D . . . . . . . . . . 347
E. . . . . . . . . . . . . . 348 


\section{LIST OF ILLUSTRATIONS}

From Nairobi to Kikuyu . $\quad . \quad$. $\quad . \quad$. . . . Frontispiece

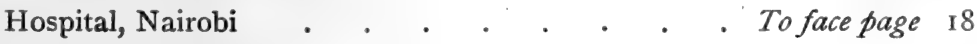

Cave Dwellers on Elgon . . . . . . . ” 26

Masai Warrior . . . . . . . . . $\quad$ ” 34

Kikuyu Maids . . . . . . . . . $\quad$. 34

Superintending the Harvest . . . . . . " " 84

Settlers on the Uasin Guishu Plateau . . . . " , 94

Sisal at Punda-Milia . . . . . . . . "

Ploughing and Reaping on Lord Delamere's Estate at Njoro . . . . . . . . . . ., 122

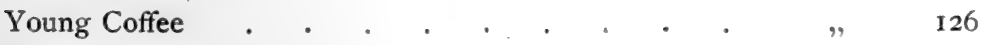

Half-breds . . . . . . . . . . $\quad$ " 134

Young Ostrich Chicks . . . . . . . . .

A Corner of the Farm . . . . . . . . " 146

Graded Sheep . . . . . . . . . $\quad$. 153

Forest behind Naivasha . . . . . . . " 156

Magadi Soda Lake . . . . . . . . $\quad$, 178

Magadi Lake : Digging out the Soda . . . . ” $\quad 178$

Cattle and Sheep on the Morendat River . . . , 186

Kilindini Harbour . . . . . . . . " , 198

King's African Rifles. (The Raw Material) . . . ” 205

King's African Rifles. (The Made Article) . . . " 205

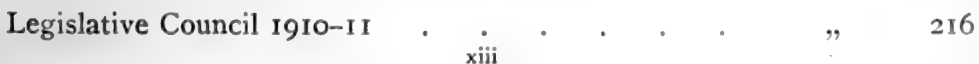


The Second Generation To face page 224

Effect of Impact on Bullets . . . . . . " 2232

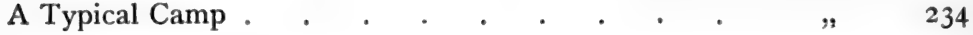

Gerenuk . . . . . . . . . . " . 260

Grant's Gazelle . . . . . . . . . , , 260

Lesser Kudu . . . . . . . . . " 260

Pig-Sticking on the Uasin Guishu Plateau . . . " $\quad 262$

Domesticated Eland in Harness . . . . . " 266

Zebra Feeding with Donkeys . . . . . . " 280

Dead Elephant • . . . . . . . . " 282

The Haunt of the Plain-Dwellers . . . . . " 288

Judging the Sporting Dogs at Nakuru Show . • . " 298

Through the Reserve . . . . . . . . . On page 3 II

The Chania Falls. Famous for their Fishing and Hotel To face page 318

A Trout Stream of the Future . . . . . . " 320

The Masara Hunt. Meet at Government House . " 334

MAP

East Africa Protectorate . . . . . At end of Volume 
A COLONY IN THE MAKING 



\title{
A COLONY IN THE MAKING
}

\author{
CHAPTER I
}

INTRODUCTORY

LESS than a generation ago East Africa was not even a name. Twelve years since, even, the Protectorate was held generally to be some sort of an appendage of South Africa to which portion of the continent indeed letters were generally addressed. Halve this period and it took a more definite shape: "British East Africa, Mombasa and Nairobi? You know, the place where they have a railway and shoot big game!" At the present time the answer given in a general knowledge Paper might be: "The British East African Protectorate is a huge tract of healthy highlands extending from Mombasa to Lake Victoria Nyanza. It is kept as a game reserve for lions and such-like, which millionaires and Americans get shot for them, and write about afterwards. There are some settlers who stone their Governors and shoot natives." Even such a concise answer would not be wholly correct.

British East Africa forms in some respects the most peculiar of his Majesty's Dominions in that within so comparatively small an area it embraces so much

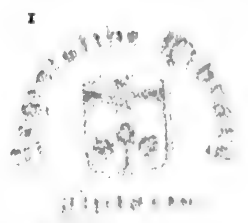


variety; a variety of climate, a variety of soil, of human inhabitant, of flora, of fauna, and finally of possibilities for British enterprise.

It is essential to lay considerable emphasis on the restricted size of our country, more especially with regard to its possibilities of colonisation. A glance at the map reveals the fact that the Protectorate contains a great many square miles. It is, in fact, equal in size to Great Britain and France taken together. The map, however, does not reveal how much of this area is in reality excluded. There are the comparatively unhealthy regions on the coast and round the shores of the Great Lake. There are the huge desert tracts. There are also the reserves for forest, for native, and for game. In none of these, as things stand now, can the white man live and have his home; and if you take them away, the area that is left, and the area on which in the main we base our hopes, is restricted. Ten million acres will swallow up most of it. Ten million acres, even with the fringes and additions of debatable land which will some day be of a certain economic value, do not constitute a large area on which to form a colony. It is absurd to think of it as on the same plane as Canada, Australia or South Africa. Yet such are the advantages that this small area offers, and such are its possibilities, that it is not premature to suppose that on it will live a population comparatively dense and essentially prosperous, forming not the most insignificant portion of the British Empire. One thing is fairly certain, and that is, that at the present day it offers prospects to a certain type of colonist that can be nowhere excelled if indeed they can be equalled.

At present - it is early days yet-the Protectorate 
has hardly found her feet ; though every day she gets a surer foothold. The reason of this is twofold. She suffers as yet from the extraordinary variety and difference of the numerous commodities that offer possibilities, and more than possibilities, of profit. Also, she suffers from the form of Government under which she labours. Both matters will right themselves. At the present day, as each enterprise is proved, it offers a smaller profit than the original speculators anticipated. Except in fairy tales and occasionally in mines, this is the invariable experience throughout the world. As a consequence, the next speculation, as yet untried, finds numerous adherents. Every day, however, certain products get hall-marked as staple industries, and every year it gets more and more realised that in a small country we must stand by the extra fine quality of a few productions rather than by their quantity and variety. With regard to the system of Government, the Protectorate subsists mainly at the present day on faith and hope. The principal ground for complaint lies in the quantity of cooks who contrive to spoil the flavour of so excellent a soup. It is extremely difficult to get an answer, or at any rate a quick, definite answer, to any question or complaint through the long chain of links which separate the settler from the Colonial Office. Thus a small privilege or exemption may be wanted from the District Commissioner. The District Commissioner approves, but must ask the Provincial Commissioner. The Provincial Commissioner, though personally in favour of the request, is somewhat doubtful as to how far native rights will be infringed, and must inquire of the Land Officer and Crown Advocate. Fortune favouring the settler, the Crown

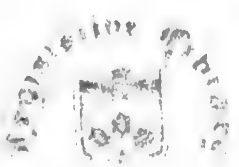


Advocate thinks that all is well. Later on in the year the Land Officer, after many conscientious inquiries and marginal notes, expresses his approval, but has to refer the whole matter to the Governor. From the Governor the matter crosses the seas to the Colonial Office. In this office it rests for a while, to end up finally with the Secretary of State for the Colonies. Here, if it is too trivial, - and that it is trivial indeed God knows-to become a matter of political importance, there is a chance of its final settlement. Now doubtless there is much to be said for such a system, and indeed there must be when the success of our colonial policy as a whole be considered; still the delay is not appreciated by the settler, who, in the main, prefers a link in the chain, overriding tradition, to give him a straight yes or no to his request.

What are the assets of the Highlands of the country? They start with its climate, which is a glorious one. The question of its transcendent health-giving attributes is discussed later, but there can be no question whatever of the pleasure and joy in life which it affords. The next asset lies in the soil, which is rich and abundant. No need here to look for alluvial washings or pockets; all, or nearly all, the soil is good and waiting to be tilled. Another asset is our grazing, which is all that the heart of man can desire. Then there are our rivers, which are abundant, and many of which are clear and beautiful. Again, our forests are almost unsurpassed in Africa, and as they stand are worth many millions of pounds. Labour in the Protectorate is plentiful and intelligent; a fact that not only increases the value of our land a hundred per cent, but adds more than that to the comfort of living thereon. We 
have in most portions two seasons, a fact never to be lost sight of in estimating our prospects. Communication in the country is good, and is increasing in facility every year. Last, but to the Englishman by no means least, the sport of all kinds is not to be surpassed. Drawbacks of course there are, and it is by no means the aim of this book anywhere to conceal the same. Apart from the disadvantages just mentioned, there is the distance of the highland to the coast, and the even more important distance from England. Three weeks from door to door compares badly with the week or so to Canada or British Columbia. Still this distance is one that affects the visitor and tourist more than the settler, though naturally the distance to his principal markets, with the corresponding enhanced freights, is to the latter a serious consideration. The absence of minerals in any quantity is held by many as another drawback, while all admit the seriousness of insect and other plagues. It should be borne in mind, however, that these plagues and pests are not especially numerous. In severity they have been surpassed in many of the most prosperous parts of the globe. What really troubles us is the fact that they are new, and that fresh means of dealing with them must gradually be adopted. Every year sees two or three insect or other pests got in hand, and if another one or two newcomers make their appearance the balance has never yet failed to be on the right side. Another distinct drawback, but one shared by all new colonies, lies in the lack of educational facilities. This is more especially so in secondary or higher education. It is a drawback which was at first inevitable, and 
one which is yearly being remedied by the exertions of the Government.

No account of any country, however new and small that country may be, can hope to be complete. Even if every expert were gathered together for the purpose, they would then only look at each subject from a partial point of view. Moreover, when their work was done it would be already hopelessly behind the times; and that is so more particularly in a country which is changing and growing with such rapidity as our subject. Herein no attempt is made to deal in any but the most superficial manner with a few aspects of the Protectorate. If there is any aim at all beyond the pleasure of writing about a land held in most affectionate remembrance, it is to supply an answer to the more general questions of the ignorant wouldbe settler, and to give him an idea of what he may find, and how he may find it. One thing can be confidently stated: that is, that any newcomer possessed of energy and determination and the requisite amount of capital will make a decent living and may, I think he will, do more. One other thing also may be stated with absolute assurance: that is, that no one who comes out will fail to love the land of his adoption, or be his luck bad or good, his success small, moderate or great, will regret the step that he took, or the day he landed in Mombasa.

Of late the possibility of an amalgamation between the Protectorate of British East Africa and Uganda has been mooted, and in I $19 \mathrm{IO}$, as a preliminary step, Sir Percy Girouard went up to Uganda to report on the advisability or otherwise of the change. Doubtless there are both advantages and disadvantages in 
placing the two Protectorates under one administration; which of these outweighs the other depends on the point of view taken by each man interested. It will be noticed that whenever plans for amalgamation or decentralisation are mooted, a magnificent case is made for them and each is held out as furnishing the one essential for a renewed prosperity. The latest cases of amalgamation in the Empire are the Federation of the South African Colonies, and, in a smaller way, of Northern and Southern Nigeria. With what trumpetings of delight and self-congratulation they were heralded, and what evidence they furnished of advance in civilisation and progress! Great Britain is presumably equally civilised; but here the goal aimed at is its dismemberment. With an outburst of glcrification Home Rule is to be granted to Ireland, and to be followed by the same priceless gift to England, Scotland, and Wales. Next century, in all probability, we shall advance once more. The United Kingdom will be federated once again under some labour or Irish despot, and Home Rule will be granted to the Orange Free State, Cape Colony, the Transvaal, and Natal! To the ordinary individual, therefore, there does not seem to be anything much in it, but one thing at all events is certain. There will be no economy in administration or diminution in the amount of officials employed. Every change means an increase both of expense and of officialdom, however much this fact may surprise the perpetrator of each great reform.

This particular amalgamation may have much to recommend it, but from one point of view at all events I suggest that there is reason for opposition. This is from the point of view of those who see in the Highlands of British East Africa a colony of the future. 
Those men who have this hope and look with every confidence to an ideal which they are sparing no pains to bring about, have one weak point in their programme. The healthy Highlands form, in their full extent, but a portion of the Protectorate. Even that full extent is curtailed by forest, native, and game reserves. The white settlers have task enough as it is if from the small area at their disposal they can hope to leaven the whole mass. What chance they have will be reduced to a minimum if to this mass be added the native kingdoms of Uganda, with their teeming population and all the other areas absolutely unsuitable to white settlement. It is admitted, to be sure, that certain areas in Uganda may support Europeans, but it cannot be denied that the balance is overwhelmingly in the other scale. To take up the burden of sleeping sickness alone would be to shoulder a load which, for many years, must be beyond our strength.

From the point of view of the present administration there may be advantages. Doubtless a strong case could be made by anyone wishing to make it. A strong case can always be produced to justify any change. There are those, however, who think that at the present day the authorities of each Protectorate have cut off fully as much as they can chew. In our Protectorate alone their mouths are fairly full. Capital is driven from the coast by defective and uncertain title, settlers are kept out of the Highlands owing to lack of surveyors to survey farms, and lack of a definite policy on which to allot them when surveyed, and forest and soil of all kind is clamouring to be unlocked for the benefit of settlers in particular, and the British Empire in general.

It is probable that readers of this book may gather the impression that, other things being equal, 
my sympathies are on the side of my fellow-countrymen. To save any misapprehension, it will perhaps be well to confess the worst at once, and plead guilty. For some years there has been a tendency, and an ever-growing one, to decry ourselves and praise foreigners-white, yellow and black. This is the case in art, in sport, or in questions of justice. An Englishman shoots an alien. Let him hang. He flogs a native. To prison with him. An alien shoots an Englishman or a native assaults him. Well, after all, the provocation must have been very great! German methods of warfare, of mechanics, and even of colonisation-save the mark!-arouse our enthusiasm : while, of course, in matters of literature and art we lag woefully behind. As for sport, it is a well-known fact that when we win a series of international encounters, it points only too plainly to our decadence, seeing that we devote ourselves wholly to sport, neglecting meanwhile matters of real and vital importance, such as woman's suffrage or plural voting. On the other hand, should we be beaten, our state is even worse, pointing to nothing else than the rapid deterioration of British physique and pluck. I believe none of it, but rather that the Britisher and American is as superior to the rest of the world, not even excluding the German, as he has been for 300 years. This self-depreciation is only a temporary, if rather loathsome, skin-disease on our naturally healthy skin, and will disappear with the first wash of a national emergency. Consequently, I say that though as a matter of course both the native and the Indian should receive fair and equitable treatment, yet the first and prime consideration of our Government should be the well-being and prosperity of the British colonist. 


\section{CHAPTER II}

RELATING TO HEALTH AND CLIMATE

Naturally the first question asked, if not by the intending settler, at all events by his parents and relations, is, what sort of climate is he going to and whether his health will not be ruined while his purse is being filled? The whole subject of health and climate is generally roughly condensed, into the question: "Is British East Africa a white man's country?" And this is a question which may be met by an indignant affirmative or an enigmatical shake of the head in accordance with the various interpretations that may be put on it. By a white man's country one man means a country in which a white man can go about his ordinary avocations as in England without danger to his health. Another man means by the qualification a country in which it is neither necessary nor advisable for a man to go " home" periodically for a change. Yet another means a country in which not only will children be born and do well, but in which they too will marry and have children who will do equally well and the race be carried on in perpetuo. As will be seen, therefore, the question in itself is one to which a direct affirmative or negative is impossible.

As to how far $\mathrm{a}^{\top}$ man can go about his ordinary 
avocations, the answer must be that it depends on what are those avocations. Roughly speaking, with regard to any but the most severe forms of manual labour not accomplished under cover, there is no doubt whatever that they can be carried out in perfect health and without discomfort. There are, indeed, many who say that there is nothing that a man can do in England that he cannot do equally well in the Protectorate.

To me that seems going rather far. I do not believe that a man could, for instance, go on ploughing or digging all day and day after day without being in danger of falling a victim to nervous collapse. Neither do I believe that he could do so on the high veldt in South Africa; though there the climate is in some respects the finest in the world. Luckily, in East Africa there is no need for a man himself to do the manual work on a farm. It is essentially an overseer's country. Once the oxen are broken and the native taught, continuous manual labour in the sun is no longer necessary. Under cover and out of the sun there is no danger in hard physical work. Thus an engineer or smith can engage in his tasks and suffer no ill effects whatever ; though perhaps he might be well advised in not attempting too long working hours. Except for any heavy continuous work the sun will not affect anyone. A man can walk all day, shoot all day, do mixed tasks all day and be better for the work.

Then as to the necessity for a periodical holiday : we again have a debatable and much debated point. The fact is really that the country is as yet too young in white occupation for an authoritative answer to be given. As each year we get additional evidence it certainly appears more probable that the periodical holiday is more in the nature of a luxury than of a necessity. After the 
first two or three years there seems to come a time when the settler feels used up and longs for a change. If, however, a change is impossible, after a year or so this feeling wears off and the customary health and spirits are regained. The case is probably on all fours with the visit to the sea which is prescribed for the children of the rich. Thus the millionaire's children in Park Lane look a little peaked and run down; so do his chauffeur's children in the mews behind the house. To the former comes the family physician, and after the usual formalities of looking at the tongues and patting the tummies of his little patients, prescribes a change at his favourite watering-place. No one looks at the children in the mews. After a month back come the rich man's children fully recovered, and the doctor receives the congratulations of the parents on his advice and its effect, also incidentally a fat cheque. Oddly enough, however, the children in the mews have also recovered their normal health and spirits, either with no treatment at all or with the assistance of perhaps one unsavoury bolus. Some of those who hold the view of the majority that there is no necessity for a change are for that reason against the periodic holidays received by the servants of the Crown, such as District Commissioners and others. I cannot be in agreement with this view. Not only would the Protectorate be served by an inferior class of official were they deprived of the inducement of the holiday in England, but the complete rest and absence from worry enjoyed at home means that they will return to harness with renewed zest, and more than make up by their zeal for the time that they have missed.

As to the sterility or otherwise of the third genera- 
tion : that generation must come into being to prove the truth or otherwise of pessimistic forebodings. It must be pointed out, however, that British East Africa is not the only high plateau on the Equator which supports a white population.

There is one thing certain about the climate of the country, apart from the question of health, and that is to live in it is ideal. Take Nairobi as a sample of a very considerable proportion of the country. The mean high temperature is about $76^{\circ}$ and the mean low about $50^{\circ}$. What is called the hot weather are the months of January, February, and March. Even then it is rare for the temperature to rise above $80^{\circ}$ or not to fall below $60^{\circ}$ at night. There is, however, an absence of breeze and an increase of dust which makes the inhabitants glad when the first showers herald the long rains, which usually last about six weeks during April and May. This is by no means an unpleasant time. The mornings are nearly always lovely; there is a cool breeze, a bright sun, the young grass is springing up and the flowers are coming out. In the afternoon, usually about 4 o'clock, clouds come up and there is heavy rain for two, three, or more hours. During this month Nairobi used to be one large, muddy morass; but new drains and metalled roads have altered all that. June, July, and August are the glory of the year: usually cool, almost cold, cloudy mornings, breaking out in the afternoon into delicious evenings. September and October are warmer and generally cloudless, and during November and December come the "small" rains, of about a month's duration. At higher elevations it is naturally colder and more rainy and a frost is first met with between 7,500 and 8,000 feet. 
The principal diseases of the country are: Malaria, dysentery, typhoid, sunstroke, lion bites, and whisky.

The settler may avoid the last two by not laying himself open to the one nor indulging in the other, or if so indulging by doing so in moderation and with all due precautions.

Of malaria, without in any way wishing to minimise the seriousness of this scourge, it may be said that it is regarded in a much graver light at home than it really merits. Most of those who have had experience of both would, I venture to say, infinitely prefer an ordinary go of malarial fever to a heavy cold. It is less unpleasant and more easily cured. The danger in malaria lies in neglect. An attack comes and is over in a day; the patient dismisses all thought of it. In a month or so it returns and the same thing happens. It comes again a little sooner, and perhaps in rather a more severe form. At last either through a heavy dose of quinine taken with a rising temperature, or owing to the nature of the beast, the ordinary malaria attack turns to blackwater and heavy trouble ensues. Luckily, in the Highlands themselves malaria is most uncommon and blackwater almost unknown. Still, as long as a large proportion of the white population descend to unhealthy areas either for sport or plantation purposes, so long will there be cases of malarial fever; and so long also will those few specimens of Anopheles mosquitoes which exist in the Highlands be infected. It is well, therefore, to bear in mind that after an attack of fever the blood can and should be completely purged of the disease. On the principle, however, that prevention is better than cure, every farmer should see to it that his house is free from mosquitoes. There 
is, of course, only one way to ensure this; that is by personally seeing to it that the insects have no breeding places near the house. First see that the farm be not built near any shallow, stagnant water. Luckily, there is comparatively little such water in the Highlands. Then see that no water is allowed to collect in any of the gutters; also that the bath-water is emptied where it will be absorbed in the ground or will run clean away. Remember that it is possible to breed 50,000 mosquitoes in one sardine tin filled with water. Have no banana trees near the house and curb your passion for cannas. The first form, perhaps, the most favourite breeding place for mosquitoes, as they invariably provide water where the leaves spring from the stem. Cannas do the same in a lesser degree. The Anopheles may be known by his habit of standing on his head, while his less harmful cousin stands with body parallel to the wall. Although the latter is held guiltless of malaria, he need not be treated with any great degree of trust or friendship. $\mathrm{He}$ is, at all events, a most unpleasant disturber of slumber.

Typhoid is a quite recent arrival in the country. It is at present mostly confined to Nairobi. There is a suspicion among doctors that it may be insect-borne, but the strong probability is that it is due to contaminated water. A good deal of the drinking water in the town is taken from the stream which gives it its name, the Nairobi river. A considerable number of low-class Indian coolies have lately settled along its banks, where they grow vegetables, etc., and incidentally foul the water. A new and first-rate water supply is now being instituted, and there is every reason to hope that this disease will be reduced to a 
minimum. Luckily, although there have been a good many cases in all, fatal or even serious attacks have been few and far between. It is generally held, and there is little reason to doubt, that typhoid in this country is of a far less virulent type than its prototype in Europe.

Dysentery is, of course, fairly prevalent throughout the Protectorate. The climate, however, can hardly be held responsible for this fact, but rather the careless method in which a considerable proportion of the population live. It is generally accepted that dysentery is nearly always contracted through the drinking of infected water. If, therefore, no water be drunk unless it has been boiled for at least ten minutes the chance of an attack of dysentery is reduced to a minimum. In theory, this sounds a simple and easily carried out preventative. As a matter of fact, those who know what it is to walk or hunt all day under a tropical sun and to be suddenly confronted with a deep, clear pool of water know that it is almost impossible to resist its invitation. Such deep, clear, stagnant pools are very often full of germs. Again, although the cook to your "safari" may have been told not once but many times that all drinking water for the camp must be boiled, one may rest assured that it is the exception rather than the rule for such instructions to be carried out. Filtering gives water more attraction to the eye, but is of no great avail for the stomach. There is a possible chance, therefore, that, while shooting or prospecting, an attack of dysentery may be acquired. This should never be the case on a farm, since there the settler can and should make certain of his water supply by sending a sample to be analysed. For dysentery many drugs have their 
uses, such as ipecacuanha, bismuth, or chlorodyne, but the first, and to most people the best, medicine is a very hearty dose of castor oil.

The sun is the great enemy with which the European settler must cope. Not only is there the direct danger of sunstroke, but there is the indirect danger of debility and nervous breakdown induced partly by the sun's rays and partly by the factor which compensates for the same-the elevation. Not only is sunstroke in itself very serious, but the victim of a bad stroke is more often than not incapacitated from ever again standing the tropical sun for any length of time. This being so, each incoming settler can hardly be too careful. Let him wear a sun-helmet from 9 in the morning till 4 in the afternoon, even on a cold, cloudy day. Such helmets are rather disagreeable and uncomfortable at first, but after a few months' hard wear they will gain in comfort what they lose in appearance. Again, if, as is generally the case during the hot weather, no coat is worn, a spine-pad is advisable; further, it may be borne in mind with advantage, that though a hairy chest peeping through an unbuttoned shirt is picturesque and gives the air of a pioneer, in reality the less surface exposed to the sun the better.

With regard to nervous diseases, or, rather, a nervous state induced by the combination of sun and height, there certainly seems a tendency after two or three years' continuous residence towards an irritability and a feeling of alternate elation and depression. A small grievance gets magnified into a deep wrong. A fortune appears in sight at one minute, ruin stares one in the face the next. A longing for England begins to stir-imaginary illnesses and dangers loom large. 
It must not be thought that such a state is inevitable or even common, but it is by no means unknown. For this state the climate should not be unduly blamed. The bulk of such cases are due rather to an attempt to live under conditions, or under a stress of work such as the country does not warrant. As the correct method of living is grasped, so year by year will this very minor ill diminish. Supposing an African race were to try to live in their traditional method in England, even in the most balmy summer, one can imagine what the death rate would be. When the high veldt in South Africa was first peopled by an alien race, there was at least the same tendency to nervous diseases and nervous irritability. A healthy and more phlegmatic race and life than exists there now it would be hard to find.

Lest from this category of ills a false impression as to the real and undoubted healthiness of the Protectorate be obtained, I produce the death rate of Nairobi, far from being the most healthy spot in the country.

The death rate for 1906 was $12 \cdot 5$ per thousand.

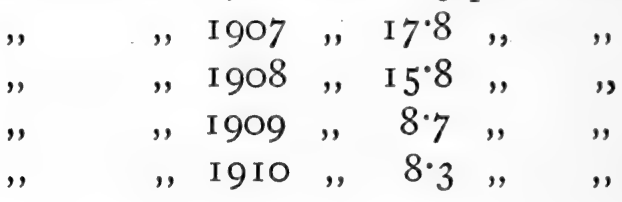

These figures prove beyond any doubt, not only the healthiness of the Protectorate, but its increasing healthiness. True, it may be pointed out that the population of Nairobi consists mainly of adults of from twenty to fifty, and that babies and young children are in less than a normal proportion. Against this, however, stand the counterbalancing fact that on 


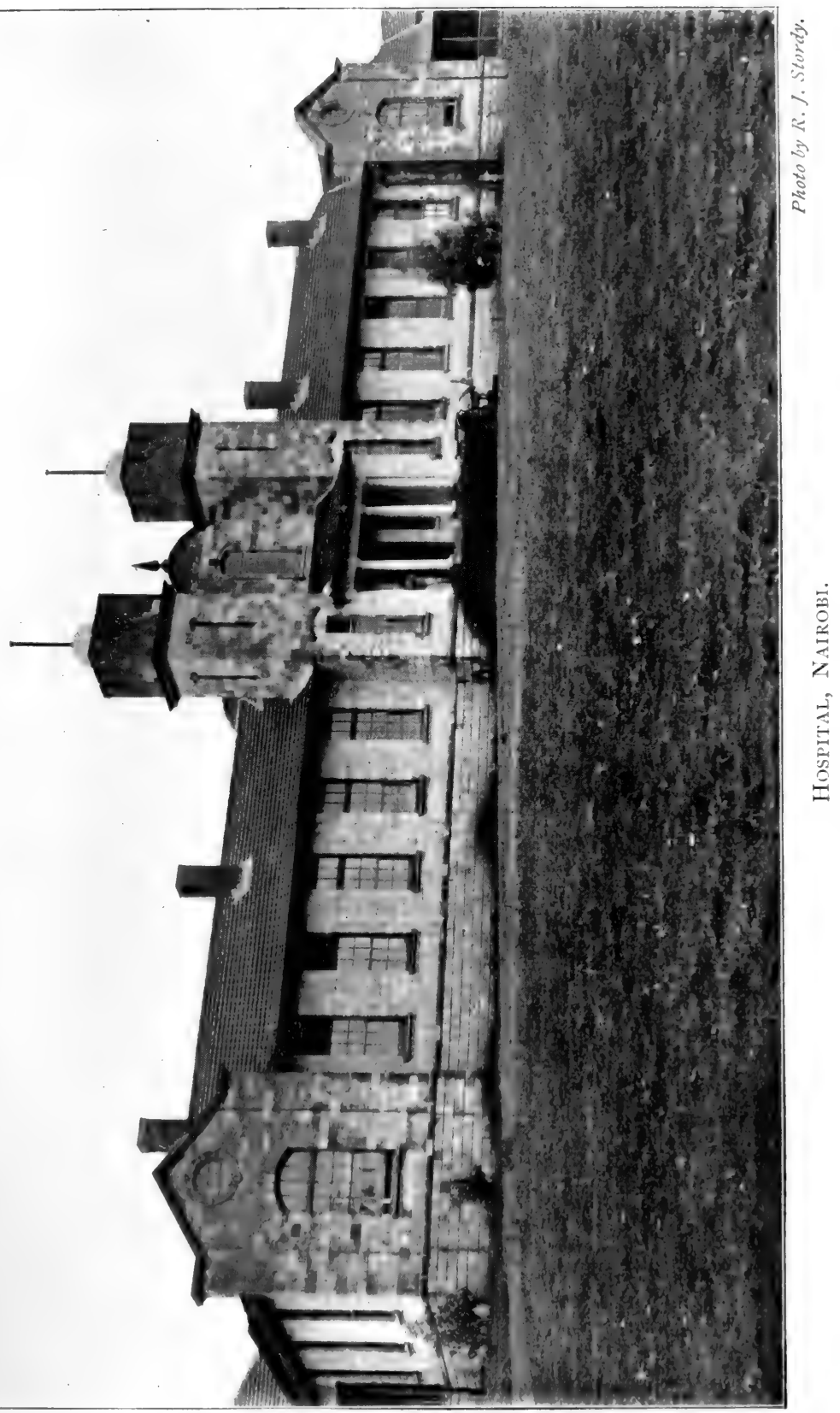


account of its hospital and medical facilities as many as possible of those who are seriously ill are brought into the capital.

Finally, one cannot quit the subject without pointing out how exceedingly well served the country is in its medical staff. Doctors are almost as thick on the ground as members of the legal profession, though, luckily, their practice is less extensive and less expensive. Not only, moreover, is the quantity sufficient, but the quality is excellent ; indeed, it is doubtful if, for knowledge of tropical diseases, the medical profession in Nairobi can be anywhere surpassed. It is only too certain, unfortunately, that with regard to lion wounds this is the case-practice makes perfect.

The European Hospital at Nairobi is a model of cleanliness and comfort, and might well serve as an example to many a larger town. The kindness, skill, and attention to which its inmates are treated can never be forgotten by any who have experienced them.

The following few suggestions as to how to keep fit may or may not suit individuals. They boast, at all events, no pretence to any medical authority.

Do yourself well in the food line. Not only are good breakfasts, luncheons, and dinners attractive in themselves, but they build up the body against the insidious attacks of the sun.

Take no alcohol by day, more especially if going much into the sun.

Take plenty of wine after sunfall, more especially burgundy and port. They enrich the blood and are agreeable to the palate.

If you get the choice, avoid a wood and iron house. Stone is best, and next to that a cedar house with a shingle roof. 
Be very careful what water you drink. If possible, don't yield to temptation, but rather eschew the drink altogether.

Only take quinine if you have fever or there are mosquitoes about. Large quantities affect the hearing, and possibly the eyesight.

If you get malaria don't rest till you have expelled every trace of the infection from your blood. A three weeks' course of quinine is requisite; 20 grains a day for the first week, Io grains every other day the second week, and five the third should absolutely cleanse the blood.

Don't go about with fever on you. Go to bed.

Periodically inspect your kitchen and the pots in which your food is cooked. It is an unpleasant task, and the result usually ends with a feeling of soreness on the part, the posterior part, of your cook. It may, however, save you a considerable doctor's bill.

Avoid chills, especially when travelling.

Always wear a "topee." A double felt hat may be more becoming, but a helmet is the only permanent and satisfactory safeguard against the sun.

Avoid worry, for worry is the root of all nervous diseases.

Bear in mind and act on the old maxim : "Keep the spirits up, the bowels open, and wear flannel next the skin." 


\section{CHAPTER III}

RACES AND CLASSES

FOR a really heterogeneous population the Protectorate of British East Africa is hard to beat.

The great diversity of climate provided by Nature is responsible in the first place for this. In an area of considerably less than a quarter of a million square miles she can produce in one part or another a sample of any kind of day or weather that you may want.

Do you desire the temperature to be warm and moist withal? On the coast or on the shores of the Great Lake we can provide you with it. If a dry heat is wanted, we have the very finest samples. Indeed, if you will cross the North Guaso Nyero, I doubt whether our dry heat can be surpassed.

A perfect balmy climate? Take Nairobi and Kyambu. Something a little more bracing and with a touch of frost? Try Likipia or the Uasin Guishu plateau. Would you have a reminder of the West coast of Scotland with heavy rain, mist and lovely days interspersed? The Mau or the Nandi Escarpment will give it you. A touch of the wind off the North Sea in East Anglia? The West Kenia plains can do that. While for something really cold and bitter you must climb up into Kenia's glaciers. 
This splendid liberality of choice accounts for the great diversity of the native tribes; and as if this were not sufficient, civilisation has added thereto the European, the Indian, the Arab, and the Boer.

For purposes of convenience I propose to divide the population into:
A. Native tribes.
B. Europeans.
C. A polyglot group comprising :
Indians,
Swahilis,
Arabs,
Somalis,

and to deal very briefly with a section of each class.

We will commence with the original inhabitants, and in doing so I shall try to encroach as little as possible on the sphere of Anthropology, but rather to deal with them from the point of view of their contact with the settler, and more especially with regard to the ever present labour question. This being so, it will be necessary to confine our attention entirely to those which inhabit or adjoin the settled areas of the Highlands, and which form almost the entire labour supply, not only for those Highlands, but for the whole Protectorate. At present the coast natives, who number some 500,000, do very little work on European plantations, these plantations being dependent on the supplies they draw from the Highlands.

The Highlands and Nyanza Basin are divided into four Provinces: The Nyanza Province, The Naivasha Province, The Kenia Province and The Ukamba Province. 
The principal tribes in each province are as follows:

In the Nyanza or Kisumu province :-

The Kavirondo Tribe,

The Nandi Tribe,

The Lumbwa Tribe,

The Sotik Tribe.

The native population was estimated at 887,000 in 1909-10, and I, 100,000 in I910-II. Undoubtedly the natives of nearly every tribe are increasing in numbers throughout the Protectorate owing to the cessation of war and the diminution of disease, but a good deal of this apparent increase is due probably to a closer census and supervision. The same cause is also partially responsible for the increase in the huttax, which has risen from 710,000 rupees in 1909-10 to 802,000 rupees in $1910-\mathrm{I}$.

The approximate numbers of the various tribes are: the Sotik 30,000, the Nandi 35,000, the Lumbwa 50,000 , and the Kavirondo close on a million.

In the Naivasha province.

We have the tribes of the

Masai,

Turkana,

Suk,

Kamasia.

Of these the Masai are, both historically and politically, by far the most important. The total native population of the province is recorded as 55,000 in 1909-10 and II 3,000 in I910-11. The Masai are probably increasing faster than any other tribe, but undoubtedly the former estimate was very 
much below the mark. The approximate numbers at the present day are: the Masai 75,000, the Turkana 25,000 , the Suk 10,000, and the Kamasia 5,000 or perhaps a few more all round. I am inclined to think that the numbers of the Masai have always been under-estimated.

The hut-tax was increased from 38,000 rupees in I 909-10 to 50,000 rupees in I910-II.

\section{In the Kenia Province.}

The native population is almost entirely Kikuyu. Its numbers are shown to be almost stationary during the last two years, according to Government Reports. Probably, however, the Kikuyu are increasing fast; the relatively small rise in population being in reality due to the fact that larger gangs of labourers leave the province every year to work elsewhere. I should put their numbers at approximately I, 200,000.

Hut-tax in the province has shown a much larger growth proportionately during the same period, namely from about $4 \mathrm{I} 7,000$ rupees to 600,000 .

\section{In the Ukamba Province.}

We have the remainder of the Wa-Kikuyu and also the Wa-Kamba. The native population is said to have been 288,000 in $1909-10$ and 320,000 in I9IO-II. But, necessarily, the census of the Wa-Kamba is by no means accurate. I should imagine that they alone number considerably over a quarter of a million.

Hut-tax has increased during the same period from 253,000 rupees to 340,000 rupees.

Of these various tribes the Kikuyu and Kavirondo supply practically the whole of the labour utilised by Government or settlers, the Kikuyu in far the larger 
share; they are therefore, for our purpose, the most important. The Masai, however, have both historically and politically been such an important factor, not to say stumbling-block, in the development of the country that they too demand and deserve considerable notice.

The Kikuyu and Kavirondo on the one hand, and the Masai with to a lesser degree the Nandi, Lumbwa and Sotik, on the other, seem to show the distinct characteristics presented to us in Jacob and Esau. The difference is most marked if we take the Kikuyu and the Masai. The former, as I shall show, are sly, cunning, deceitful, cowardly, and devoid of all sense of honour, yet through their brains and numbers economically useful. As a tribe they seem to resemble the character which is depicted to us in the person of Jacob. The Masai are picturesque, brave to a degree, boastful, quarrelsome, comparatively faithful and honourable, and yet economically useless. They represent Esau, and as far as anything can be humanly certain, it is certain that they too will lose their birthright.

These two, the leading types, will therefore be taken at more length and we will dismiss the remainder shortly.

The Kavirondo-form the second largest source from which labour can be drawn, and for agricultural purposes undoubtedly the best. Although they are nearly always alluded to as one tribe, yet Kavirondo in reality are divided very sharply, not only into two tribes, but into two races: the Nilotic Kavirondo and the Bantu Kavirondo. Yet the two sections, though so ethnologically different, have almost exactly similar customs and habits, and, unless expressly stated other- 
wise what applies to the one may be considered as applying to the other. The Nilotic tribe inhabit the east shores of Lake Victoria Nyanza in the region of Kavirondo Bay. The Bantu Kavirondo occupy the district north of the former including the Nzoia valley, of which Mumias is the capital.

Probably the Kavirondo have attracted most attention from one rather curious feature: the fact that neither sex is accustomed to wear a single stitch of clothing. I take it that hardly a tourist or shooter but has returned from the Protectorate the richer by a large bundle of photographs marked "private" depicting adult Kavirondo of either sex in full costume, which consists in the case of the women of as many beads and necklaces as her position warrants, and in the case of the man of a very elaborate head-dress. It is not surprising to find that both sexes are exceedingly moral and respectable. It may be true that beauty unadorned is beauty adorned the most, but it is equally true that female beauty of form concealed, yet hinted at, is more attractive to the male sex. It may be presumed that it was this immoral desire for admiration, mixed with curiosity, that induced Eve to adopt her first petticoat. This immoral desire still lies dormant among the Kavirondo. Apart from, or in addition to, this trait, the Kavirondo have always had much to recommend them. They are peaceful, industrious, and essentially agriculturists. What little fighting they have ever done has been either with the Nandi or the Kisii, with neither of which fighting races could they ever hope to compete on even terms. Luckily for them, in the old days they never possessed a sufficient head of cattle to excite the avarice of their neighbours. Their huts are by no means badly built, 


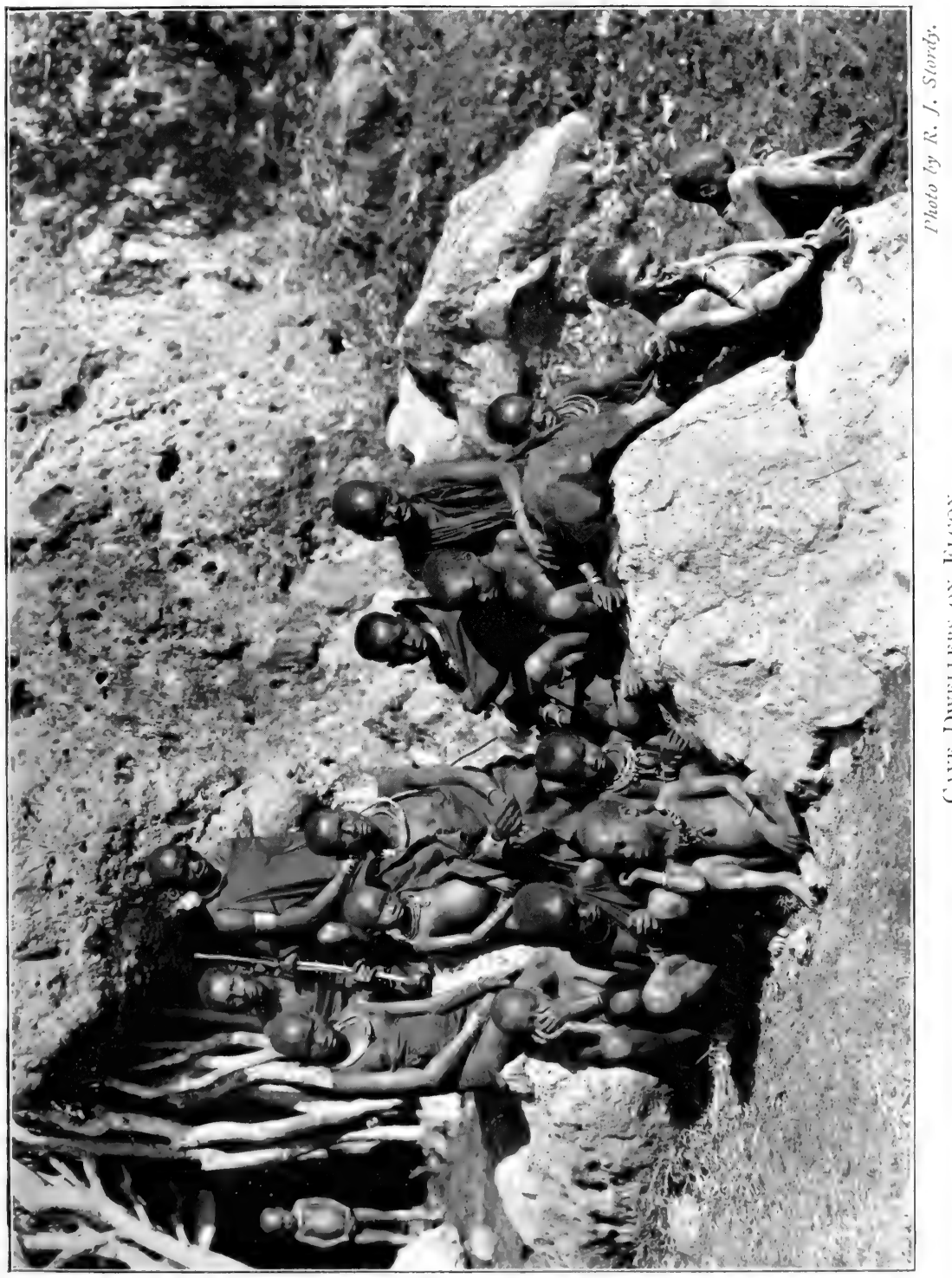



and their villages are usually surrounded by low walls or fences. It is as agriculturists that they shine, and as such are sure to have a considerable influence on our future prosperity. The eastern shores of the lake, if somewhat unhealthy for Europeans, possess a deep, rich, loamy soil that is second to none in the Protectorate. In the past, the Kavirondo has grown naturally only such crops as he has required for his own food, e.g., maize, sorghun, etc. At the present day, however, the soil and his services are being exploited both by Europeans and Indians in the production of more valuable crops, such as rubber, coffee, sim-sim, cotton, etc. More than $£ 44,000$ worth of native produce was despatched by rail in 1909-10, and $£ 66,000$ worth in I910-I I from the district inhabited by the Kavirondo. Seeds of various kinds have been supplied them by the Government, and in this respect it is impossible to speak too highly of the work accomplished for this tribe by the Provincial Commissioner, Mr. John Ainsworth. Whether this exploiting of a tribe to the detriment of the European is quite so satisfactory is another question, and one on which two very diverse opinions may be held.

As a labourer the Kavirondo form without doubt the best material in the country. In numbers they are surpassed by the Wa-Kikuyu, but in nearly every other essential they have the advantage over the latter. Thus, in the first place, the men are physically stronger, this being mainly due to the fact that the male Kavirondo has always been accustomed to do a very considerable proportion of the field-work, instead of leaving the whole of it to the womenfolk, as is the case with most tribes. Then he is a much more cheery individual and also more trusting and trustworthy. 
Thus he does not demand his wages on the day they are due or rather generally two or three days before, as is invariable in the employment of Kikuyu. Very often he will not take his wages until the end of six months, perfectly confident in the honesty of his employer. Although by no means adverse to petty thefts and crimes, he does not, up to the present, at all events, combine to put the screw on his master, but rather accepts just punishment when necessary with complete equanimity.

It must be borne in mind that the natural habitat of the tribe is very warm and moist, and that therefore he cannot be expected to be at his best at first in the cold, dry high plateaus. On the wind-swept Uasin Guishu plateau, for instance, he is at present far from happy, and to induce him to stay there, every facility and help in the way of superior housing is necessary. The next generation will undoubtedly be more inured to the climate. On the other hand, if the exportation of any highland nation to the coast is to be encouraged, the Kavirondo offer the most suitable material.

The tribe, both Nilotic and Bantu, are prolific, but has suffered a great deal in the past from smallpox and sleeping sickness. The former has been held well in check by the Government; the latter seems about stationary. There is a sleeping sickness observation camp in South Kavirondo, but its efforts at effecting a cure have, as elsewhere, been up to the present without avail. At the same time, there can be little doubt that the observations on this scourge are proceeding on the right lines, and that, without being unduly optimistic, one may anticipate the vital discovery within the next two years. One thing is certain, that though prevention may be better than 
cure, the latter is in this case the better if not the only hope.

The natives of both sections are very much given to the excessive use of intoxicants, which fact it is advisable for employers to bear in mind. They are not particular as to whether it be of native or European manufacture.

The Nandi, to whom are allied the Lumbwa and Kamasia tribes, occupy the southern portion of the Uasin Guishu plateau extending from the Nandi escarpment, which runs parallel to the railway line from Kipigori to Londiani, northwards for a distance of thirty miles.

This tribe form the second-most important of those tribes which we describe as of the race of Esau. This importance is partly because the country they inhabit, known as the Nandi plateau, is one of the most beautiful and fertile portions of the Protectorate, and also because, though few in numbers, they have managed to be a very considerable thorn in the side of the Government.

In old days before the completion of the Uganda Railway the caravan road lay through the Nandi country, and certainly in proportion to their numbers this tribe were as great a danger as their more celebrated neighbours the Masai, and through their agency a good many Europeans lost their lives. Later there have been at least three expeditions against the Nandi, one in 1900, another in 1903, and the last in 1905. The first two were moderately and the last eminently successful. The warriors fight with spears and poisoned arrows, the latter a most unpleasant method of warfare. Luckily, in the last expedition we took the tribe unprepared-they had indeed become 
so used to our threats as to treat them entirely as bluff - consequently their poison was for the most part stale and our losses consequently much fewer than they would otherwise have been.

The Nandi are the hereditary enemies of the Masai, and certainly, as far as one can judge, had none the worse of the frequent encounters between the two tribes. On the plains the numbers of the Masai would seem to have given them an advantage in their traditional method of warfare; but where there was cover and the bow could come into use the Nandi at least held their own.

Like the Masai, Turkana, and Suk, the young Nandi men are organised as a special class of warriors ; and in the past they have undoubtedly regarded raiding and war as essentially the business to which they had been born. From a settler's point of view, however, the future of the tribe is less a cause of anxiety than is the case with the Masai. Unlike the latter, this tribe have always had a tendency towards agriculture, and this tendency is growing every day. It is not, perhaps, too much to hope that before long the Nandi may become entirely agricultural and pastoral, and further that when their own Reserve gets filled up, they may provide a further source from which outside labour may be drawn.

The $W a-K a m b a$ form to my mind the intermediate link between the sons of Esau and the sons of Jacob. They inhabit the basin of the Athi and the large Kitui district, and have during the last few years increased in numbers and extended considerably. Apparently the tribe have never been aggressively warlike, but when attacked have defended themselves with success both from the Masai to the north-west and the Gallas 
to the east. They rely principally on poisoned arrows, to which weapon their country, which is very heavily bushed, lends itself admirably. There are probably at the present day at least 350,000 in the tribe, but though they are remote from civilisation and their country is both difficult and unhealthy, yet they have given the British Government very little trouble. The section of the tribe who live round our abandoned station of Mumoni are perhaps not yet thoroughly acquiescent in our rule; but that in so short a time and by such peaceful methods this large tribe should be settling down quietly to accept our administration is a very eloquent testimony to the splendid work done by the small band of officers stationed in Kitui, one of the most depressing and unhealthy spots in the Protectorate. More especially does this apply to the late Mr. J. B. Ainsworth, whose efforts in achieving so satisfactory a result undoubtedly cost him his life.

The Wa-Kamba are somewhat unattractive in appearance and character, very much given to drunkenness, and without morals of any sort. They are both a pastoral and agricultural race. Their cattle have increased in number greatly lately, and as they have not for some time suffered from famine, which from the nature of their country must occur periodically, they are at present very well off. Owing to this fact they have not to any extent augmented the labour market, but it is reasonable to expect that they will do so in the future. There are good hopes that this tribe may prove of very considerable service to the Protectorate. They are by no means unintelligent, and must clearly be amenable to authority. In one respect they surpass any natives with whom I have come in contact, and that is in the extraordinary and intuitive grasp they 
have of machinery. This is a very wonderful trait, and when, as is probable, we shall shortly see a large increase of machinery such as mills, steam-ploughs, motor-ploughs, decorticating machines, etc., it is likely to prove extremely valuable. 


\title{
CHAPTER IV
}

\author{
THE MASAI
}

ThE tribe of the Masai, though comparatively insignificant in numbers, yet merit more than passing interest, if only for the obstacles in the past, the difficulties of the present, and the problem of the future which they present to white civilisation. They stand as a type, the type of Esau. They and the lesser tribes of the same sort have, like Esau, the qualities that attract : courage, straightforwardness, and independence. But, like him, they have the demerits of want of application, dislike of discipline or authority, and contempt of work. They will be fortunate if they do not share his fate. As Sir Charles Eliot so well says: "They resemble the lion and the leopard, strong and beautiful beasts of prey, that please the artistic sense, but are never of any use, and often a very serious danger."

With the early history of the Masai it is not necessary to deal at length, indeed, as is natural with a paramount and exclusive tribe, it is merged in obscurity. From the time when the first explorers penetrated its wilds, up till the time of the occupation of the Protectorate by the British Government, the tribe were the masters of the East African Highlands. 
Whether under some single despotic ruler they sprung into notice is uncertain. The probability is that, like the Zulus, their supremacy was sudden and temporary. Certain is the fact that, in the first half of the nineteenth century, and indeed for the next forty years, theirs was a name to conjure with. North, south, east and west, they raided; to the coast on the east, Lake Victoria on the west, far into German East Africa on the south, and beyond Mt. Kenia on the north. The object of their raids was a lust for fighting and a desire for cattle. Women they never took ; neither male nor female might marry outside the tribe. They attacked Mombasa, they sacked Vanga. Early travellers, European or Arab, were confronted and forced to pay tribute (hongo). To what extent they were feared, a perusal of almost any of the works of early shooters or explorers will show. At the mere mention of the word Masai rifles were loaded, laager was formed, and tribute was to hand! Possibly to a certain extent this universal respect was founded on "omne ignotum pro magnifico"; at all events Mr. F. J. Jackson, formerly an ardent shooter and naturalist, now Governor of Uganda, once stood up to them with no ill effects. Again, as far as we know, they were none the better for their periodical encounters with the Nandi. Still, of their prestige there can be no two questions. Their decline began through natural causes and came so quickly that it is a fair presumption that their rise was equally rapid. Somewhere about I 890 , the Masai were themselves visited by famine and smallpox and their cattle by rinderpest. They suffered enormously, and in the dissensions that inevitably ensued split into two fractions. Their great chief, Mbatian, died, and one portion, remaining in British 

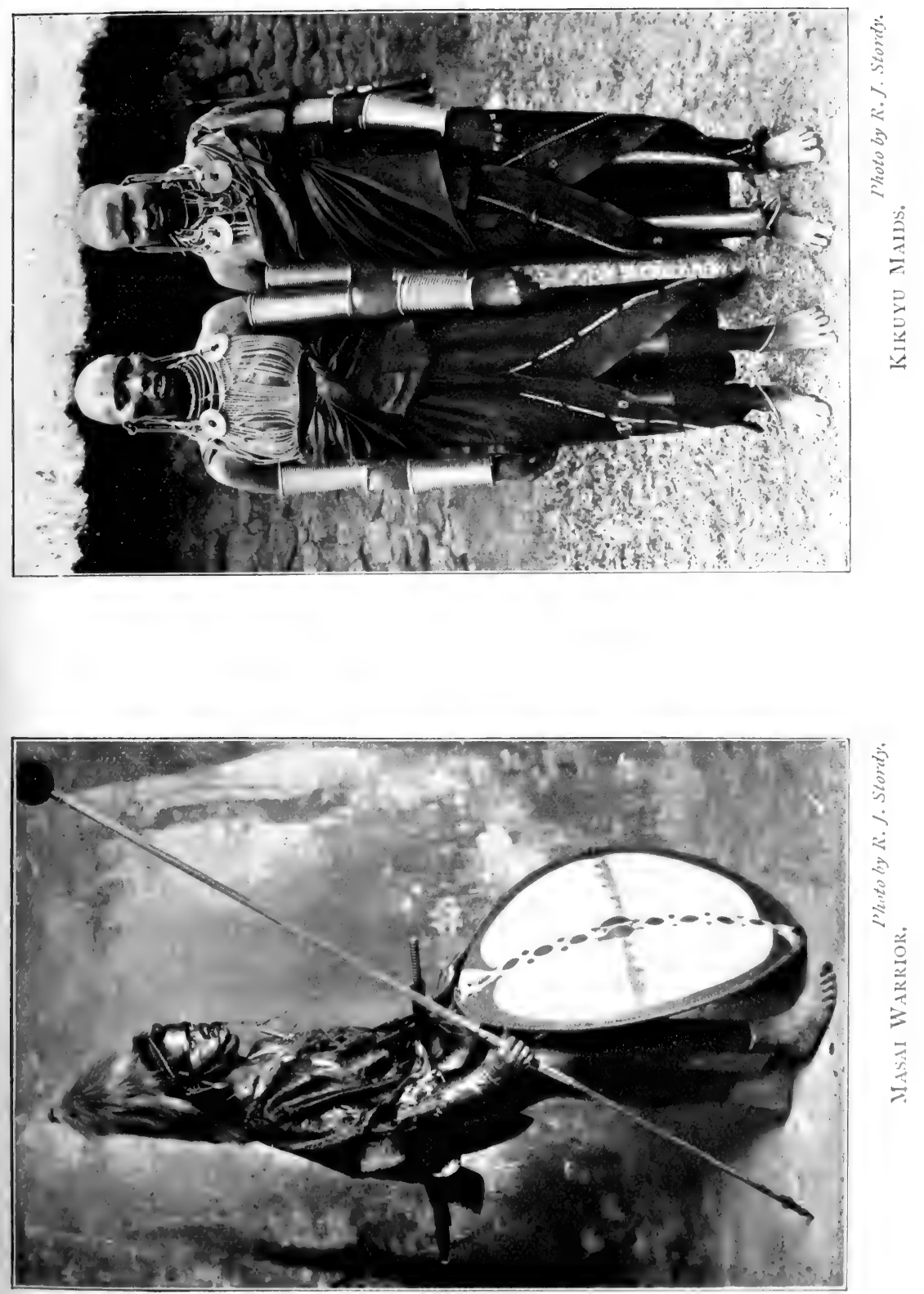

East Africa, acknowledged allegiance to his nominated successor, Lenana, while the other, removing into German East Africa, took as their chief Lenana's brother, Sendeu. The two sections carried on a bitter tribal war till 1902, in the meanwhile more or less suspending their attacks on other tribes. By 1902, Sendeu appears to have had enough, and the whole tribe agreed to acknowledge Lenana as their paramount chief. In the meanwhile was coming the white man, and gradually his influence was being felt. We were unable to control the raiding propensities of the Masai till after 1898 , when the last raid on any large scale took place. That we have been able to do so without bloodshed must always be a feather in the cap of the administration, which feather is largely due to the good influence of Lenana. This chief, enlightened and far-seeing beyond any native representative in East Africa, was always on the side of order and of the British Government. To his good influence the British owe the fact that white blood was not shed, and the Masai that their territories are wide beyond their deserts.

When the first white settlers began to arrive in the years 1901-2-3, the question of what territory the Masai could really lay claim to demanded consideration. The Masai were of course a nomad people, and they drove their flocks over a very large area to wherever the grazing was temporarily the best. If any other natives happened to be in possession, or to want any special area, they were driven out. The ruling Masai maxim was "might is right." The would-be settlers arriving, saw on both sides of the railway large tracts of splendid grazing land, apparently not occupied at all, certainly not utilised to one-tenth 
of their capacity. They applied for farms in these districts. At this time Sir Charles Eliot was H.M.'s Commissioner in the Protectorate. He saw at once the difficulty presented by this fierce nomad race; that not only were they a menace to the prosperity of the country and of its inhabitants, white and black, but also that they themselves must inevitably stand in danger of degeneration if not of extermination. $\mathrm{He}$ realised the two alternatives; the first of giving them a reserve large enough to allow them to carry on their own mode of wandering life, the second to make an attempt to induce them to abandon their habits and gradually to become useful members of society by curtailing their area and interspersing it with European farms and settlements. Realising the inevitable difficulties and dangers it evolved, he chose the latter policy, which policy was immediately reversed by his successor, Sir Donald Stewart, with the connivance, or rather at the instigation of the Home authorities. In considering the two views there is one thing that must not be lost sight of, and that is this-Sir Charles Eliot was an extraordinary man, almost without doubt the ablest and most far-sighted that the Protectorate has seen up to the present date. His book in itself-" The East African Protectorate"-reveals, not only the wonderful knowledge that he had of all sides of the country during the period of his administration, but also an almost uncanny prescience of events that were to come. But Sir Charles Eliot was more. He stands almost unique among Colonial Governors as a man who sacrificed his career rather than give way over a point in which he believed his personal honour to be involved. It is to be hoped, and indeed it is sure, that his name will live as long as 
honesty and honour are held in esteem among his countrymen. On such a question as this such a man was not likely to take the line of least resistance, and indeed it was in pursuance of his policy that his resignation was enforced. Sir Charles Eliot gave out to white applicants certain farms in the district over which the Masai were accustomed to roam. The Home authorities, disregarding the fact that they themselves in the same territory were giving a grant of many times the area to a private company, ordered him to cancel the concessions. Sir Charles, in reply, pointed out that he had given his word in a matter in which he was certainly entitled to pledge it. The Government refused to give way, and sooner than break his promise the Commissioner sent in his resignation. One cannot but feel that when a man sacrifices his career, sooner than a question of principle, his opinion is entitled to more than ordinary respect.

The essence of the problem seems to come to this: here we have a people who, beautiful to look at and in some ways attractive in character, have as far as we know never been of any use to any living soul. Like ravening beasts, they have lived on the weakness of their neighbours, amongst whom they were classed with pestilence, famine, and disease. Have this people any inherent right to be conserved in this condition? Have we not rather a duty to execute by leading them, or forcing them, to be of some economic use, or perish? I conceive that it is some sentimental feeling which says: "You are preserving the wild fauna of the country in its pristine condition; will you withhold the same privilege to the Masai?" If it were possible, which I deny, to treat wild animals on the basis of even the lowest of humanity, one might retort : 
"Is any reserve designed to preserve carnivora alone?"

However, to resume. In 1904 Sir Charles Eliot was banished and Sir Donald Stewart installed in his stead. According to the instructions he had received the latter reported that the only policy was to sequestrate the Masai in an enormous Reserve, and a treaty to effect this object was entered into on August 9th, 1904. In this treaty the Masai was divided into two sections-as far as possible in accordance with their own clans and subdivisions-and these two sections were interned in two areas, known as the Northern and Southern Masai Reserves. The Southern Reserve is a district lying between the Ngong mountains and the German boundary. The Northern Reserve was to be an area on Likipia, North of the Guaso Narok, and was carefully defined. This treaty was drawn up with due solemnity. If the Masai had any idea of what they were signing, certainly the Government had not. Great point and stress were laid on the words that the treaty should hold "for all time." As a matter of fact, it actually held for less than six months, when the Government, finding somewhat late in the day that there was no water in the Northern Reserve, had to delineate fresh boundaries. Furthermore, it has been broken by one side or the other ever since. The Masai, on the one hand, have never made any attempt to keep within their Reserve, while we, on our side, very promptly alienated the road, which, half a mile in width, was to communicate between the two Reserves.

The easier course thus decided on, the Masai moved into their two Reserves and for a time all went comparatively peacefully. True, the Masai never made 
any attempt to keep their side of the bargain. Not only did they at certain seasons of the year move far beyond the bounds marked out for them in both Reserves into territory temporarily unoccupied, but they even spread themselves all over the farms marked out, but not yet given out in holdings, and furthermore, a considerable number broke new ground altogether and settled themselves on the Loieta plains, which lie to the west of the Southern Masai Reserve. Still, for a time, this encroachment gave little more than paper trouble.

During this period, fostered in an unnatural manner the Masai flocks and herds increased abnormally. What head of stock the tribe possessed during its period of ascendancy can only be conjectured; but owing to their perpetual state of warfare it can never have been very large. The outbreak of rinderpest in I89I and the ensuing years reduced the numbers to a very low figure. After the epidemic there was, as usual, a period of exceptional fecundity, and by 1904 a careful estimate gave them in all 50,000 cattle and 600,000 sheep. This total actually grew by the beginning of 1910 to 130,000 head of cattle and 2,230,000 sheep.

Now it must be remembered that not only are the Masai a very small tribe, there being at the most 50,000 souls in all, but that they make no use whatever of their cattle. They simply hoard them as a miser does gold and cannot be induced to sell a single cow or sheep. In these circumstances this excess of wealth is of no benefit to anyone, least of all to themselves ; indeed it may be fairly submitted that we have no right, let alone duty, to supply one single additional acre to pasture herds grown beyond all legitimate bounds. 
Up till 1908 this state of things continued. In that year the objection to the two Reserves seems to have dawned almost simultaneously on the white settlers in the country and on Lenana, paramount Chief of the Masai. The settlers, who, it will be borne in mind, had no share whatever in the former treaty, felt it unfortunate that they should be cut off so far from the railway by a tribe to whom its proximity or use were a matter of complete indifference; while Lenana found that the distance which separated the Northern Reserves from the Southern, in which he personally lived, weakened his authority on the two sections and tended inevitably to split them into two tribes. In I909, a direct proposal was made to remove the Northern Masai to the Loieta plains, adding that area to the Southern Reserve and thus bringing the whole tribe together once more. Such a proposal gave an increased area of good grazing, but with an insufficient supply of water. The next twelve months were occupied with considering the question and in finding out the wishes of the body of the Northern Masai. It was found that these Masai were almost unanimously in favour of the move, and it was proposed to remedy the water question by the expenditure of a large sum of money in irrigation. Early in 1910, the Governor, Sir Percy Girouard, held two meetings with the authorised Chiefs of both Reserves; all were in favour of the move, an agreement was come to, and almost immediately, unexpectedly soon in fact, the move commenced.

Then it was that the official conscience of the British Government, spurred into life by certain somewhat officious vote-controllers, awoke. "What is this fearful thing going on?" they cried, "A treaty made 
' for all time' is being destroyed, and the unfortunate natives are being turned from a paradise into a desert to please our worthless countrymen. Let us stop the move." And stop it they did. The Masai who had already moved were bundled back and the Home Government proceeded to satisfy themselves both of the bona fides of their own agents, and also of the fact that the Masai were genuinely ready to move. The whole process of interrogating the Chiefs was accordingly gone into all over again. Now the Masai, oddly enough, resembles his white brother in one thing, and that is his intense dislike of being, in the language of the East End, "mucked about." This time Legalishu, one of the principal Chiefs in the Northern Masai, said that he had had enough of moving, and that the new area was too small. The whole negotiations therefore fell through.

Early in I9II, by a curious dispensation of Providence, Lenana died and left as his dying wish an instruction that the Northern Masai should come south and that the whole tribe should be once more united. Such dying wishes have great weight with this tribe, and influenced by it, and also possibly having forgotten some of their very justifiable resentment, Legalishu, and the other great Chiefs from the north came in of their own accord and expressed, not only the willingness, but the desire to move. A treaty, safeguarded with every formality, was drawn up and signed, and once again the move commenced.

Such, briefly, has been the history of the relations of this tribe with white settlement and white Government. I find it difficult to believe that an unbiassed perusal can lead anyone to the opinion that the tribe has received any but the fairest treatment from their white 
fellow-subjects or rulers. At all events, with the white settlers themselves the page stands clean. There are those indeed who say emphatically that the Masai are the spoilt child among the native races of the Protectorate.

Individually the Masai are far from unattractive. Both men and women are slight and well made, with pleasing features, though with somewhat high cheek bones. The average height of a man might be ${ }_{5} \mathrm{ft}$. 7in., of a woman $5 \mathrm{ft}$. 4in. They are always spare and one would have to search a long while to find a representative scaling Io stone. The work, what little there is, is always done by young boys or old women. Once every five years a circumcision ceremony is held, and the young men considered fit to bear arms are initiated by circumcision to the rank of warrior. The initiation ceremony over, the warrior should proceed at the earliest opportunity to justify his existence by some deed of arms. If there are plenty of lions handy this justification can be worked off at their expense. If not, there is always a danger of trouble. A warrior may not marry, but lives with one or more concubines of his own age. Traditionally, though these warriors did no work, they kept themselves in the highest state of training for the raids or battles which continually occurred. The warrior marries the lady of his choice after his fighting days are over. A married woman is supposed to remain chaste, but since in the ordinary course of events she has had so much previous experience, this rule is probably more honoured in the breach than in the observance. During the age of childbearing, a woman performs none but light household duties, but when that is over the whole work of the family, added to much of the village work, falls to 
her share. Thus the old women (ditos) build the huts and kraals (manyattas), carry firewood and water and keep guard. The old men are given to intoxication, but all spirits are forbidden to the warrior. The women are very much addicted to adornments of iron or copper wire, and if wealthy enough will encase the whole of their arms and legs with spiral ornaments, adding an enormous frill round their necks. The discomfort experienced by the most wealthy must be almost equivalent to that endured by the most fashionable European lady in full war paint. The demeanour of the Masai is dignified and reserved. They dislike, and to some extent despise, the white man. Still, they are not incapable of gratitude, and exclude certain Europeans from the general throng. Thus they have an esteem for Lord Delamere and his brothers-in-law, Messrs. Galbraith and Berkeley Cole, and will confer favours on them for which anyone else, settler or official alike, might ask in vain.

The bravery of the Masai is proverbial, and among themselves and in their traditional method of warfare or lion-hunting can hardly be exaggerated. If, however, they are taken out of their own country and put to face the unknown in forest or jungle they are capable of showing themselves as human as the rest of us.

As regards the future of the Masai, the outlook can only be described as gloomy. There can be no place eventually in a British Colony for a tribe that will neither work for themselves nor others; who breed cattle but will not sell them; whose militarism is a continual menace to the peaceful population, and who in a word are no credit to encroaching civilisation. As far as one can see, if they are to avoid the degra- 
dation of the North American Indian, their sole hope lies in some internal change of character and habit, whereby they may become useful members of the community. If time or any influence can induce the young men either to cultivate the soil, or to go out as herdsmen or syces, if the tribe can even be taught to regard their surplus cattle as negotiable, there is hope. We may be assured that the Government will spare no pains to attain this end. 


\section{CHAPTER V.}

\section{THE KIKUYU}

THE Kikuyu tribe is, for the purpose of the white settler, undoubtedly the most important in the Protectorate. This is because it provides, and will provide, the greatest proportion of the unskilled labour.

This tribe inhabit a very large tract of country extending to the Equator in the north, the slopes of Kenia to the east, Nairobi and Fort Smith to the south, and the railway line to the west. The plural of the name should be properly Wa-Kikuyu, i.e. a Kikuyu or two Kikuyu, but the Wa-Kikuyu, in referring to the tribe; as a matter of fact, however, they are usually, though ungrammatically, alluded to as "the Kikuyu." Oddly enough, their neighbours, the Wa-Kamba, are usually called Wa-Kamba, both singularly and generically. If the kindred tribes at Meru and Embu be included, the full tribe numbers roughly a million, and is rather more numerous than the Kavirondo and four times as great as any other tribe ; moreover, they are increasing very rapidly.

In point of physique they are poor, the men perhaps averaging $5 \mathrm{ft} 4$ in. and the women $5 \mathrm{ft}$. It must be borne in mind, however, that, if one judges 
solely by the labouring class, one is apt rather to underestimate the male physique. If he can possibly avoid it, the young able-bodied Kikuyu warrior will not condescend to do one stroke of work. The labour in his own fields is done almost exclusively by women, while the men sit on and watch. Mr. Routledge considers that this custom is a survival of the period when the males had to stand armed and ready to protect their wives and families. Myself, I think that it is due to the delightful feeling, so well known to us all, engendered by lying at ease and watching others work. Sentimentalists who see in the trait only the splendid independence and glorious freedom of the savage would find very different names if our own able-bodied young men sat all day in the public house while they left the whole work of the country to be done by their wives, children, and parents.

It must be confessed that a young warrior is rather an imposing sight with his long spear in hand and his sword girt to his side, his hair picturesquely tied, wire ornaments round neck and arms, his goat skin thrown over one shoulder and Collobus monkey skin around his ankles. His courage, however, has always been in inverse ratio to his attire.

The women, however, are much better developed than the men-indeed for their size they are extraordinarily muscular, especially in regard to the carrying of loads. Brought up from the very earliest age to the bearing of burdens such as water, fuel, grain, etc., they become capable of absolutely surprising feats in this direction. Whereas the male Kikuyu porter grumbles at, and indeed is generally physically incapable of, carrying more than $50 \mathrm{lb}$., a 
woman will think nothing of roo lb. In a certain privately owned forest near Nairobi it is, or was, customary to allow the women to cut and take away for the sum of half a rupee as much dead wood as they could carry. This involves the ascent of quite a steep hill. Yet one bundle, being weighed, turned the scale at $\mathrm{I} 8 \mathrm{O} \mathrm{lb}$., and $\mathrm{I}_{5} \mathrm{O} \mathrm{lb}$. would be by no means unusual. The weight of the damsel herself would very rarely exceed $100 \mathrm{lb}$. It is probable that it is this excess of physical strength over the male which accounts for the very fair proportion of women's rights that they possess. The load is always carried on the back supported by a strap round the forehead. This method dates from the time, of which indeed it is a proof, when they lived mainly in the woods. The Wa-Kikuyu were originally almost entirely a forest-inhabiting race. Until quite recent times nearly the whole of the tract they inhabit was one vast forest. The amount of destruction they have accomplished in this forest ever since it has been under our protection is almost appalling. It is rather difficult to understand how or why a tribe which, from time immemorial, has existed in and through the agency of forest, should suddenly commence to destroy the same wholesale, but I imagine the answer lies in the altered conditions wrought by the introduction of the Pax Britannica. The Kikuyu were always a most miserable, cowardly race, preyed upon by their neighbours on all sides, but more especially by the Masai. This wholesale spoliation both kept their numbers down, and made a forest into which they could flee and hide a matter of necessity for their existence. Now that they live in peace and without fear, they have increased and are 
increasing enormously, and find that a large area of cleared land is essential for their maintenance. The fact that this tribe, at all events, owes, not only its property, but almost its very existence to our rule should be borne in mind in their administration.

In appearance they are ugly, without being repulsive, though the horrible distortion practised on the lobes of the ear bring some of the plainer specimens almost into the latter category. Here the men have the advantage of the "fair" sex, as many of the young males have decidedly graceful carriage, while the continual hard work undertaken by the females, and more especially the carrying of loads on the back, destroys any pretensions to a good figure. There is among the Wa-Kikuyu themselves no further standard for female beauty than physical strength and the capacity for hard work.

The tribe have always been and are an entirely agricultural one, and though their methods are very primitive, the richness of the soil gives them an ample return. Their principal crops are beans, maize, millet, sweet potatoes, tobacco, and castor oil. For food they eat meat, honey, and flour, the two former being luxuries, the latter their staple diet. They keep both cattle and goats, but rather as a standard of wealth than for any practical use. The unit of wealth is a goat. Thus a native field or "Shamba" is said to be a one, two, or three goat shamba. Cows, heifers, and bullocks are worth each so many goats. The average price for an average wife would be about 35 goats, or say two cows and ten goats.

Their huts are rather above the average native type. It is advisable, however, not to visit the interiors, as, in addition to sheltering sheep, goats, and chickens, 
they have a wonderfully fine stock of the jumping flea and the burrowing jigger.

The Wa-Kikuyu are fond of dancing. Some of their dances, such as those given at the circumcision festivities, are peculiar, but their usual dances have little besides indecency to distinguish them. Very little inducement will set them off dancing, and both officials, from the Governor downwards and also shooters and globe-trotters, are pretty sure to be regaled with an "Ngoma" at any native centre. The object of such an Ngoma is partly to work off their animal spirits and to display their finery and partly in expectation of favours to come; and in this spirit it is usually understood. One youthful big game shooter, however, received their advances in a different spirit. $\mathrm{He}$, with his wife and party, were encamped within a few miles of Fort Hall. Towards dusk the usual procession of greased and painted warriors and maidens appeared. Hastily our young friend formed his delighted porters into a square and received the flabbergasted dancers not with the customary rupee but with shots over their heads. They fled in dismay. I was pleased to see from a review that appeared in a fashionable paper that the party while travelling an unexplored part of darkest Africa had been assailed by a savage tribe, which, however, was repulsed by their coolness and courage.

They die principally from old age, starvation, pneumonia, and venereal disease. When, as occasionally happens, the crops fail entirely, the improvident native suffers heavily from famine, and in the past the mortality has been dreadful. At the present time, the Government take the matter in hand and minimise the death-rate as far as possible by importing 
food. I have always thought that it would be a matter of common fairness at such times to levy a tax on the native-owned cattle to pay for this relief. A Kikuyu, though not so certainly as a Masai, would generally prefer to die than to part with a head of stock.

The tribe suffers dreadfully from venereal disease, and terrible sights are to be seen throughout their territory. It is sad to reflect that before the coming of civilisation they were absolutely clean of this scourge. They owe its ravages entirely to the Indians, by whom it was introduced.

After death, except in the case of the upper ten, the disposal of the bodies is left entirely to the hyænas; in my opinion rather a nasty form of funeral.

The Kikuyu arts and crafts consist of a little rough pottery and iron work.

I notice that when an ethnologist describes a tribe with which he has made himself personally acqainted, he is apt to follow Mr. Jorrocks' advice with regard to horses and be "to their faults a little blind and to their virtues ever kind." He will generally have you believe that a native's faults are all on the surface, and when after much search you get to know him he, the native, is one solid mass of virtues. Thus $\mathrm{Mr}$. Routledge, who has written the standard work on this tribe, and a most excellent book it is, has discovered that really the Kikuyu is practically without fault. I think most employers of labour will agree with me that the skill with which these merits are concealed is worthy of a better cause. To speak candidly, they are a most unattractive race, and with the exception of their fecundity and a certain amount 
of intelligence their merits are mainly negative. They lie, they steal, they poison; they conspire, they are intensely lazy, and they are callously cruel. Still, there they are, and such as they are we must make the best of them. Taking first his virtues: The Kikuyu does not fight, and unless in overpowering numbers would never dream of disputing the authority of the white man, whether his master or otherwise. This virtue, though eminently commendable, is not a very attractive one, since it arises solely through fear. The Kikuyu always has been and always will be an arrant coward. Then again he has been described as, and to a certain extent is, comparatively sober. This virtue is due to the fact that he has very seldom sufficient money to buy, or sufficient energy to make, enough liquor to produce intoxication. Provided he can steal a bottle of spirits his moral scruples will not prevent his having a glorious carouse. The one real good quality possessed by the Kikuyu lies in the fact that he has quite a respectable quantity of brains, more especially with regard to agriculture. This talent he shows both in regard to his own fields and also in the intelligent way in which he picks up and grasps European methods. An instance of the latter is shown in the way in which he picks up ploughing. The Kikuyu method of breaking land is about as primitive as can well be conceived, a long pole with a firehardened point being poked into the ground, and a very small spoonful of earth overturned. Neither has he any experience of working bullocks in any form. Yet in a few months we found that many natives are able to drive and work a team of fourteen bullocks, and hold a straight furrow as well as the man who taught him. They are, moreover, quite able to 
appreciate the advantage of the method, and several ploughs are already at work in their own Reserve.

Now we will deal with his faults, not in any missionising spirit, but merely from the point of view of the settler. Firstly, our friend is an inveterate liar. This delightful trait arises from the usual causes: a desire to give information pleasing to his questioner, laziness which forbids his verifying any information, or an immoral desire for gain. The first two causes are probably common to all natives; in the last, in my experience, he stands facile princeps. Where mendacity is so ingrained a remedy is very hard to find, but the evil may be mitigated by never believing a word he says. I must confess that, where a boy continually attempts to extract money by lies, e.g., says that he has completed his task when as a matter of fact he has not been near it, I believe that the "kiboko" has a somewhat salutary effect. Then this tribe are great at conspiracy; they are, in fact, born trade unionists. Thus has a labourer a grievance, it is not his habit to bring it up at once, but rather will he conspire with his mates till such a time as he thinks that his master is in a fix, when he will, if possible, whet his revenge and avarice at the same time. Thus, on a farm the bullock boys think that their rate of pay is insufficient or that one of them has been unfairly treated. Will they complain at once? Not so. Rather will they wait until such a time as their wages have just been paid and when it is absolutely essential for some ploughing or cross-ploughing to be done. Then will they come up in a body and announce their intention of deserting en masse unless their demands are instantly fulfilled. To safeguard against this absolutely is impossible, but it is well to provide against it as far as possible by trying 
never to let any native have a legitimate grievance, by attempting to keep in touch with any possible desires or complaints, and by preventing as far as possible any labourer or body of labourers from becoming indispensable. Remember that towards the end of the month you have the whip-hand of your labourer, but at the beginning of the month, when he has your money and you want his services, he has the whip-hand of you. Again, they are intensely lazy and cunning withal. Thus, should they be engaged on a piece of work such as weeding and be left without supervision, they will station a couple of their number on posts of observation, probably up trees, and sleep, smoke, or eat until such time as he cries, in schoolboy language, "cave." To cope with this it is necessary whenever possible to use task work, and I believe that there are very few kinds of work to which the system cannot be applied. Moreover, they are able to see and appreciate the justice of it. Their use of poison is not endearing; but the strong measures taken by the Government are bearing fruit, and it is to be hoped that as a crime a few years may see the end of it. As poisoners they are extremely expert and brew of the same more than one kind. In common with other forest tribes, the shooting of poisoned arrows was the traditional method of warfare. The poison used is obtained from a small bush-like tree, which is fairly common throughout Kikuyu, and is generally given a "sweetener" by the addition of poison obtained from snakes and spiders. When fresh, it is extremely deadly, and experiments have proved that the minutest prick will kill a sheep in from two to ten minutes. There have undoubtedly been cases of both cattle and 
ostriches being wantonly destroyed. Now, however, it has very rightly been made a punishable offence for a native to have such poison in his possession, and it is hoped before long definitely to stamp out this crime. The Kikuyu is also well versed in the manufacture of poison to be taken internally. There have been one or two instances in which Europeans, and I fear a good many in which natives who were loyal to their white employers, have been made away with by this method. I have come across more than one instance in which the threat of poisoning a Kikuyu foreman was made, and undoubtedly one in which the threat was carried out. It is, unfortunately, extremely difficult to prove, both because all Kikuyu evidence is unreliable, and because the hyæna offers the customary mode of burial, a mode prejudicial to post-mortems. With regard to their cruelty, I will give one very common offence which has apparently escaped $\mathrm{Mr}$. Routledge's observation, when enumerating the Kikuyu's virtues. When a desire for meat seizes the Kikuyu herdsman and he thinks that the chance of detection is slight, he will select his opportunity and force a sharp-pointed stick or a cleft-stick with a stone in the cleft up the anus of an unfortunate animal, until the bowels are pierced. The stick is then broken off short and left in. In a day or two the animal dies a death of frightful agony. The herd then reports that a bullock has died of disease, and if the owner is young and ignorant the carcase is thrown away, and the revels commence. As a word of advice, let me suggest that in the case of the death of any head of stock the owner thoroughly satisfy himself as to the cause, and having done so let him see that the carcase is entirely destroyed. 
Lastly, we come to the most serious defect in the Kikuyu character, and that is his extraordinary dishonesty. The Kikuyu will steal any mortal thing he can. I believe that beside him even the famous ${ }^{1}$ Welshman is immaculate! He will take the crops from your fields, the stores from your storeroom, the fruit from your trees, and the cattle from your yard. With it all he is so cunning. The settler has a heap of firewood neatly cut and stacked. It stands behind his house and having finished the supply that he has within the same he goes to his stack to replenish it; seizing a $\log$ he pulls and to his astonishment and disgust the whole edifice collapses! His Kikuyu boys have very carefully abstracted the whole of the interior, leaving merely sufficient outer crust to keep a semblance of the original heap. I have seen the same thing with regard to maize stored on a platform with thin-meshed wire walls. The mesh has been very carefully cut and then replaced so that the removed square cannot be noticed, and then night by night cobs have been removed from the interior and the wall of grain built up again and the square of wire replaced. Again, a tunnel has with infinite trouble been dug beneath the wall of a shed and a calf contained within removed!

However, with regard to petty thefts, vigilance and severe punishment will do much; but the serious problem is with regard to the theft of cattle, and more especially of sheep. Where flocks and herds are large it is almost impossible to detect or prevent this form of crime, which, I fear, is on the increase. The police have proved powerless to deal with it, and farmers have considered the advisability of taking the

1 Reference is made to one "Taffy" and not to any later prototype. 
law into their own hands and even gone further than mere thought. I fear that it is impossible to consider the question without, at the same time, considering the case of the deportation of the Hon. Galbraith Cole, which excited such deep indignation in the Protectorate, and even a certain mild wonder at home. The facts were shortly these. Mr. Cole was a pioneer sheep-farmer, a man who devoted himself to his business and left politics and agitation alone. He was, perhaps, the man most universally respected by farmers and natives alike in the country. Mr. Cole began to suffer from sheep-theft, and informed the police; they proved powerless. The thefts increased; he vainly tried to protect himself by legal means; but finally gave fair warning that unless he could get adequate protection he must take the law into his own hands. A little later he caught two Kikuyus red-handed with the skin of one of his freshly-killed sheep; this being the third occasion on which these self-same men had been detected. They attempted to escape and he called on them to stop. They refused to do so and he fired at one, killing him. He then made an undoubted error of judgment in not reporting the matter to the authorities. The Kikuyu who escaped did report the matter, and Mr. Cole was arrested and tried for murder. The jury without leaving the box found him not guilty.

A month or two later Mr. Cole was deported as being dangerous to the peace of the country, nominally by order of the Governor, actually by order of Mr. Harcourt, Secretary of State for the Colonies.

Now, for the benefit of those who sit at home at 
ease and so glibly order the affairs of better men, I would submit the following arguments.

The police and Law Courts exist to maintain the law of the land. In any old-established country they have the ability and power to do the same. While they have this power and ability it is the duty of every citizen to leave the maintenance of law and order to them. But in undeveloped countries, and in special circumstances, the Law Courts and the police are powerless to administer justice. In such circumstances it is not human nature, nor is it right and proper, that citizens should sit still and allow lawlessness to run riot and the efforts of honest toil to become fruitless. In every savage country it has been proved that up to a certain point it is absolutely necessary for settlers in certain cases to take the law into their own hands for the protection of themselves and their property. Among such cases the case of cattle theft has always been pre-eminent.

Among the tribes of British East Africa, and more especially among the Kikuyu themselves, the penalty for a stock thief caught red-handed is death; consequently, when the penalty is inflicted by a white man, no sense of injury or injustice is felt. It is such considerations as these that moved, and I submit not unreasonably, the jury in considering their verdict.

One thing is certain, and that is that practically every settler in the country was in agreement with the verdict; further that had destiny called out $\mathrm{Mr}$. Harcourt and his colleagues to East Africa instead of guiding their steps to the Front Bench, in all human probability they too would have been in complete concurrence. 
Let us take now the action of Mr. Harcourt and his sympathisers. They disagreed with the verdict, and with the considerations that moved the jury who found that verdict. They might have taken two courses; either on some technical grounds they might have annulled the trial and had another, or else they might have decided that the settlers were unfit to have any share in the administration of justice and have done away for a time with trial by jury. For either decision, although extreme, it would have been possible to find some justification. Neither course, however, was taken but a man who was found innocent in a court of justice was condemned out of hand on evidence which he had no opportunity of hearing, and awarded a heavier sentence than he would have incurred if he had been legally condemned. How does this accord with the British sense of justice or the maxim that "every man is innocent till he is proved guilty"? The hypocrisy of the action of the Colonial Office is brought out in the reason assigned for Mr. Cole's deportation, namely, that his presence was a menace to the peace of the Protectorate. Mr. Harcourt must have known very well that Mr. Cole was one of the most popular, if not actually the most popular, settler with the native population. If it had been possible to utilise his advice and good offices, the muddle effected over the movement of the Masai would almost certainly have been averted. $\mathrm{Mr}$. Cole was well- or ill-advised enough to accept quietly the punishment imposed upon him. Possibly the fact that he was in poor health at the time had much to do with his decision; but it is to be hoped that the Home authorities will not be led on by this acquiescence to repeat the experiment. If there is one thing more than another 
which is likely to lead to dissatisfaction, to use a mild term, it is a feeling that the interests of a small and at present powerless Colony are being sacrificed for the sake of the acquisition of a few Party votes.

This unfortunate case illustrates only too clearly the difficulties caused and likely to be caused by this penchant for stealing among the tribe. That it will be stamped out before long there can be no doubt; settlers, officials, police, and justices alike are determined on this, and no efforts are being spared by one or other of them to bring it about.

I fear the reader will think that I take a somewhat pessimistic view of this tribe. Perhaps I do. Let us therefore "be to his faults a little blind" and fix our gaze on his good qualities, which I take to be fecundity and intelligence. 


\section{CHAPTER VI}

\section{THE INDIAN POPULATION}

Perhaps the most difficult and at the same time the most pressing problem at present in the Protectorate is that afforded by the Indian population. Hard as this problem would be to settle if left entirely to the discretion of those on the spot and who see and know the special conditions existing, it is rendered even harder by those at home who meddle, with insufficient knowledge though no doubt with the best intentions.

If you divide the population of British East Africa roughly into three classes: Europeans, Indians, and Native population, one would have thought that logically, other things being equal, on general questions the sympathy of educated classes in England should have lain in the first place with the native population, secondly with the European, and, lastly, with the Indian. The reason that I should have expected the natives to have first claim is because of the consideration that he is the original occupier and owner. Countless centuries have seen no change in his condition. From time immemorial he has fought and worked, fed and starved, married and died, undisturbed, as far as we know, by any outside influence. Then suddenly appeared the white man, and in the twinkling 
of an eye change faced him in every direction. Moreover, I fear that, do what one will, never again will the native see as much happiness in the future as he has enjoyed in the past. Second to them in popular sympathy one would have anticipated that the European population would have ranked. Why? Because after all he is of the same flesh and blood as his critic and because too he has done his best, and a good best at that, to improve the condition both of the land itself and of the population that land contained. And, last, one would have said should have stood the Indian. $\mathrm{He}$, like the European, is an interloper, but unlike the latter he has done nothing to ameliorate the lot of the native, but, on the contrary, has done much to degrade it. Where the European has given better clothing, better and more regular food, education and medical attendance, the Indian has given disease, drink and crime.

As a matter of fact, however, as far as one can judge, the sympathies of both the home Government and of those comparatively few of the public who are interested in the subject rest in the first place with the Indians, secondly with the natives, and, "longo intervallo," with the white population. What is the reason of this curious preference? I suggest that it is made up partly of ignorance, partly of our traditional love of fair play, and partly of the growing tendency and indeed readiness to depreciate our own race in every sphere of action. The general idea of the Indian, as known to the majority of politicans and to the upper class specialists, is a courtly, cultivated gentleman living in a cool, delightful climate in the North of India. $\mathrm{He}$ is polite, clean, patriotic, and in every way desirable. The idea takes 
root and is carefully tended by pro-Indian legislators that this delightful member of the Empire is being kept out of equal rights and indeed persecuted for the colour of his skin by British colonists, who as a class are far less desirable, respectable, or polite.

Now what are the facts? The origin of the Indian population lies in the employment of some 25,000 coolies of the lowest type in the construction of the Uganda Railway. When the railway was completed, this large body of men, the riff-raff of a nation, remained, with a few exceptions, in the country. They form the basis of the Indian population therein and their numbers are increased by nearly every boat that comes from India, and unfortunately with much the same class as themselves, because the respectable Indian would be at least as loath to mix with them as is the European.

The original stock therefore was bad. And herein is no question of colour or race. If the original band of British settlers had been composed of, say, ticketof-leave men, hooligans, and militant suffragettes, it would hardly have been an incentive to respectable colonists to follow.

This large body of men set themselves to the natural task of making money. To this end they have applied themselves, not as is the British habit by developing the natural resources of the country, but rather by the draining dry of the sources already in existence.

In furtherance of this object they have exploited trade with the native, and never is a station so distant or so unhealthy but a small Indian store will make its appearance. Herein I must confess that I find grounds to admire even our present debased type 
of Indian trader. His manners and morals may be nil and his customs beastly, he may and nearly always does cheat and debase the native, but for his enterprise I have nothing but praise. There is many an outlying station in which the presence of an Indian store is almost invaluable. The money obtained is nearly all sent out of the country, usually by a "sure hand"; which trait is not one to endear the race to those who believe in the future of our country.

The settlers in the Protectorate object to the Indian under present conditions for two reasons. The first may be selfish, but is extremely natural. It is that they object to being undersold in nearly every branch of trade. It may be said, and indeed has been said, that this underselling is fair trade and fair competition and cannot be objected to. But is it fair trade and fair competition? Is the Indian a better trader or better worker than his European competitor? Certainly not ; it could not be contended that he is by his staunchest adherent. Why, then, does he undersell him? Because, as the saying is, he can live on the smell of an oil-rag. Because he eats food that the European could not touch. Because he lives in sanitary conditions under which no English farmer would dream of keeping his pigs. Because he can do without what the European considers the ordinary necessities of life, such as soap or a change of clothes. Finally, because he often sells his goods below cost price, and makes his profit by some illicit trade.

The second reason why the settler dislikes the Indian as a class is an entirely unselfish one, and I venture to say that it rouses his resentment to an even greater degree than the former. It is because of the harm, both moral and physical, that is done through 
his agency to the unfortunate native population. The settler knows, the missionaries and the police know, too, who keep the brothels, who the illicit stills, who the gambling dens, and who are the receivers of stolen property. It is hardly too much to say that in Nairobi there is hardly a crime among natives which is not directly traceable to the Indian. Then there is disease. Venereal and plague are directly traceable to the Indian by whom they were introduced. The "jigger," or burrowing flea, has caused both suffering, loss of limb, and occasionally of life among the native, and also great discomfort and loss of profit to the European. We owe this pleasant little fellow to the Indian. Before the coming of the Indian typhoid was unknown, while his filthy and insanitary mode of living is responsible for much of the ophthalmia and minor diseases in Nairobi.

These are the complaints that the settler brings against the Indian, and it must be confessed that they form a very grave indictment. It will be seen that the whole gravamen of the charge is not against the Indian as an Indian but against the Indian as a man. If the Indian in the Protectorate were represented by the type so dear to authors and tourists, we would welcome him with open arms. It is not because his skin is black that he is unpopular; it is because he is a foul liver, a drunkard, and a thief. These are hard words to write deliberately of any class, but I submit that they are justified. There are, of course, exceptions, not many but a few, worthy honest cleanly citizens, a credit to any State. Such men are welcome and would be popular, were it not that the virtues of so small a minority are overshadowed by the crimes of the vast majority. With every ill it is always easy to 
find fault, but difficult to find a remedy, still perhaps in this case the lines on which the remedy should run seem fairly clear.

The Indian says daily, and writes the same in his newspapers, that he is as good a man as the European and demands equal treatment with the same. By this he means presumably that he would take any advantages that the European may have which he, the Indian, has not, but would not incur any of the liabilities and responsibilities of the latter. I would suggest that our answer to him should be: "Very well, you say that you are equal to a European, you shall in future incur his responsibilities and live like a man and not like a beast." Thus it would be pointed out that any European entering the country has to show means of $£ 50$ or else evidence that he is going direct into some situation, and this liability would in future be incurred by our Indian subjects as well. Then I should point to his miserable hovels and say that the lowest Europeans would not be allowed to live in such as these, but must inhabit decent sanitary buildings and that this privilege would be his also. Finally, I would put forward every possible effort, and would rout out every brothel, every illicit still, every receiver of stolen property. If the owners of these "businesses" had been Europeans they would long ago have had short shrift, and the Indian claims to be at least as good as the European.

I firmly believe that by such means a plague-spot, a great and damning reproach, may be removed, and that in time the word Indian may be no longer a term of reproach but even of congratulation throughout the Protectorate. 


\section{CHAPTER VII}

THE SWAHILI AND THE SOMALI

Though not forming numerically any very considerable feature of the Highlands, these two races have managed to impress themselves very markedly thereon. The Swahili owes this impression to his language, which is the universal medium of conversation with the natives of the Protectorate, the Somali to his own dominant and acquisitive personality.

The genuine Swahili is the product of a cross between the Arab and the coast native, and should probably have a distinct trace of Arab ancestry in his features and complexion. Less correctly, any native who lives in or round Mombasa calls himself and is called a Swahili; while up country any native who has the language and has been in European employ, makes haste to lay claim to the title. This is so naturally, since Swahilis ask for and obtain a higher rate of wages than other natives.

I cannot claim to be wrapped up in any of the coloured races of the Protectorate, but of all such the genuine inhabitants of Mombasa and its neighbourhood are without doubt the best, and have often much to commend them. To take their virtues; they are firstly most distinctly clean, which is a virtue of a very 
high order. The majority of Swahilis wash pretty thoroughly every day, and are also particular as to their clothes; neither do they smear themselves, to any extent, with unsavoury unguents. As a consequence they are devoid of the noisome odour which everyone except the missionaries associates with the up-country native. Secondly, they are comparatively honest as a class, though of course there are exceptions. Perhaps I have been lucky, but I have found that if one hands over money to a Swahili for his safe keeping, one may look forward to the result with equanimity. Usually speaking, they have no exaggerated idea of the honesty of their fellows, more especially of Somalis. A Swahili who has been with me some five years is accustomed whenever he finds that I have left valuables lying about, to conceal the same in some most cunning hiding-place. Thus any rupee notes discovered will be stowed for safety in the interior of a boot, while a watch he holds it safest, if there are any suspicious characters about, to conceal within a sock or stocking which in its turn is thrust into the inner recesses of a pillow. Thirdly, the Swahili is clever, and picks up English ways, virtues, and vices with great success. $\mathrm{He}$ is most observant, and learns such things as waiting at table, cleaning pistols and guns of new pattern, bicycles, or any mechanism with the utmost despatch. Don't think because your Swahili only addresses you in his own tongue or responds to that language, that it necessarily follows that he has no knowledge of English. Many such understand every word you say.

Finally he is generally cheerful, which is, perhaps, the best trait of all. He will always see the comic side of anything - even of his own misfortunes, though 
naturally those of others and especially of his master appear to him more truly humorous. He is sublimely happy with a little music and dancing, but failing this is content to sit and gossip for hours, as will invariably be observed round a camp fire. Newcomers often wonder what all the talk is about. The answer is that, as in our Clubs, the bulk of conversation consists of indecent stories and experiences, the second favourite topic being the iniquities of his masters and superiors, which topic takes the place with us of the defects of the Government of the day.

As to his faults-laziness is one; though when there is any special occasion or any unwonted call on his energies, he may be relied on. Thus your Swahili butler will be at his best when a large and unexpected party is suddenly thrust on him; or on Safari your Swahili headman or gunbearer shines when there is an unusually long march under depressing circumstances, or the caravan has to be transported across a rainswollen torrent. It is in the ordinary wear and tear of everyday life that his laziness shows itself, or perhaps rather that he becomes bored. Dusting, sweeping, gun-cleaning, etc., require constant supervision, and in fact he will fail in any daily task after about a week, unless an eye is on him. Drunkenness is, and always has been, another failing in the equipment of the Swahili. In his own country he makes a villainous concoction, "tembo," from tapping cocoanut trees, but in the Highlands he is not averse to any reasonable substitute, such as can always be provided by the nearest Indian. Usually speaking, he does not let his love of spirits interfere to any great extent with his work. There are, however, exceptions. I recollect one dinner party at the inception of which 
the headboy was unaccountably absent. The meal, however, commenced under the supervision of his underlings and proceeded satisfactorily. Some bright sally produced a loud outburst of laughter, which was followed by the most frightful mumblings and groans from under the table. A moment later a black face with bloodshot eyes and vinous breath appeared over the lap of the staidest matron of the party. The butler had returned! The race is singularly immoral, and this applies to either sex. The ladies can be confidently expected to find husbands and the men wives in every port or station to which they may happen to come. It is unfair, however, to mark this entirely to their discredit, since it is possibly the result of their long acquaintance with European civilisation.

Swahilis are excellent agriculturists, and many of them own nice little plantations on the coast. Both Indians and Arabs have, perhaps unfortunately, dispossessed them of a good deal of land, which is probably theirs by right. This fact, however, is not an unmixed disadvantage, since it means that a larger proportion come up country in search of employment. They are not a long-lived race, but one may still come across some of the fine old fellows who knew the country before the railway, men who for a wage that would be sneezed at by their more luxurious descendants went cheerily up into the unexplored Highlands for a space of two years at a stretch, ready to face the perils of the Masai, wild beasts, hunger, and exposure, with all the uncertain terrors of the unknown. Such men must have our heartiest admiration; and as I have said, many of their good qualities are retained to the present day. 
With the Somalis in the Jubaland Province we are not here immediately concerned when we consider the white colony on the Highlands. They have in the past afforded our Government some considerable trouble, and still further cause for anxiety, but for the present give comparatively little of either. Many who should know consider that both the evil propensities and the warlike powers of the Somali have been exaggerated in the past, and that there is reason to hope that this section at all events will merge gradually and quietly into the civilisation alongside of them.

The Somali with whom the settler is more immediately acquainted is a very different and probably less attractive individual. The faction consists for the most part of men of no particular account in their own country, but full of ambition and a spirit of adventure, who have travelled into our Protectorate for one purpose only, the acquisition of money. As far as the Protectorate is concerned, the sole object of every Somali is to make as much money and in as short a time as possible, and as to the method he adopts for that purpose he is completely indifferent. It must not be thought that I impute this in any way as a crime to the Somali. On the contrary, I admire him heartily for the characteristic. As is a matter of common knowledge, the acquisition of money is the principal object of life, and if only a man obtains enough the manner in which he acquires it is really not a matter of much importance. If only Englishmen invaded Germany with the same object, and the same success, that Somalis invade British East Africa, they would meet with and deserve from our point of view nothing but praise. All I would point out is 
that from the point of view of the dwellers in and owners of the country, the trait is not quite so desirable.

Money being the objective of the Somali, two classes through which that end can be attained lie open for exploitation: the European and the native. And buth will serve the purpose according to the taste and individual characteristics of each man; the native being despoiled by means of trade, and the European through some menial occupation such as headboy, leader of a "Safari" or caravan, or as gunbearer. As a trader of sheep or stock from the natives, the Somali stands facile princeps and his success can only be compared to that of the Indian in store-keeping. No journey is too hard, no privation too great, and, I regret to add, no expedient too mean by which sheep or stock can be obtained at a quarter their true value from the unsophisticated savage. In the central portions of the country this cozening of the native will soon right itself; the latter is no fool at bottom, and is rapidly learning that there is not really any adequate reason for the enormous profit obtained by this species of middleman. It is in the out-districts that the trading Somali requires more careful watching, since to safeguard his own obvious interests he fills the minds of the natives of those parts with contempt and distrust of any white men who might be inclined to follow in his footsteps. Thus in I9Io Somalis penetrated over the Southern Abyssinian frontier and brought back very considerable mobs of Boran cattle and horses in strict defiance of the so-called Government of Abyssinia. An expedition, sent up to the same place by our Government in the following year for the purpose of putting this same trading on a proper basis, 
found that their arrival had been forestalled by the Somali-spread report that the sole object of the expedition was to poison all the scanty wells and watering places.

To understand the points whereby the Somali obtains his object through the agency of the European, the personal characteristics of the former must be considered. To start with, it cannot be denied that both in appearance and in many of his qualities he is one of nature's gentlemen. Both men and women are tall and most gracefully and symmetrically fashioned. Their features are beautifully chiselled and refined, and their voices low and melodious. Again, they are clean, and their manners, deferential without being cringing, are almost perfect; they are always courteous and ever ready to oblige. In sport they are generally both keen and tireless; though I recall two Somalis, who went as headman and hunter to a rich merchant of Semitic extraction, and during the course of a considerable expedition gammoned him that it was quite out of the question to start shooting before ro a.m., as up to that hour the game was inconceivably wild! Finally, it is as of the creed of a Somali to stand by his employer in a tight place, and he literally does not know the meaning of the word fear. There is, I believe, hardly a single recorded instance of a Somali deserting his master when attacked by elephant, buffalo, or lion; and on the contrary many and many an instance of the most desperate gallantry stands out. Cases of unarmed gunbearers flinging themselves on lions which have got the white man down will occur to many hunters. In one particular case a Somali thrust his hand into a lion's mouth and twisted the tongue of the beast to induce him to leave off savaging his master, and to turn its 
attention to himself. The Swahili, however, is staunch enough for any moderate man, and without making the same parade of heroism will invariably be found ready to place a rifle in his master's hand at the right moment, whereas the Somali has not inconceivably fired it off on his own accord and contrary to order. These, then, are his valuable qualities, and them he takes to the best market, which he usually finds in the person of those big game shooters and tourists to whom expense is no object.

In making up one's mind whether to take Somalis or Swahilis as gunbearers or in some other capacity on an expedition, the drawbacks as well as the advantages of the former must be considered. In the first place his bump of avarice and extortion is developed to the maximum degree. Not only will the Somali demand wages at least double those of the Swahili, but he will be insistent for every kind of extra clothes, boots, putties, special tents, special plates, knives, and indeed any mortal thing that he can extract. Then, of course, he must have extra food such as tea, rice, and ghee, till finally, unless one is careful, each Somali will mean an addition of two extra porters to himself, requiring of course further food and wages. Once you have got him away he will, as I have said, work well and hard, but generally speaking he will not be able to enforce anything like equal efficiency in the porters and boys, as will a Swahili of the old caravan days. Again, directly the "Safari" approaches civilisation even of the most modest order, his rapacious demands commence again; he will have lost his knife or finished his rice or tea, and will approach asking for more with a pathetic expression on his face and in his eyes like a replete spaniel begging for a piece of 
cake. The greatest drawback, however, to the race in this capacity is this, that practically without exception no Somali can spoor or understands the elements of hunting.

In the Highlands those Somalis who are temporarily taking a rest from their life's work live in a large village on the outskirts of Nairobi, while in the town itself they have their own club, wherein they are waited on by natives of base degree. Many of those who are rather pleased to observe the contempt with which the Somalis look down on all the natives of the country would be less pleased if they realised that they also class the European on a hardly higher plane and certainly as immeasurably inferior to themselves. If the confidence of a specimen of this class be obtained, as it may be, he will converse freely and most courteously on the subject. He is ready to admit that owing to a certain monkey-like cunning the European nations are richer, and in a sense more powerful than the leading African races. Intrinsically, however, Europeans are neither so brave, so enduring, nor so clever as either Abyssinians or his own people; indeed that after a while the two latter may find it worth their while to combine and expel the European from the whole of Africa, if indeed it may not prove desirable to go further than that.

It may be submitted that, with all his good qualities and personal attractions, the Protectorate would be the better for the total extinction of this in many respects charming race. 


\section{CHAPTER VIII}

\section{SETTLERS AND OFFICIALS}

Up to quite recent times the white population in the Protectorate was divided into two sharply defined camps-settlers and officials. These two classes, while each individually worked earnestly and heartily for the good of the country, had an unfortunate distrust of each other. Now while this sharp distinction, and I fear distrust, between the official and non-official classes seems growing in intensity in England, it is, I would venture to say, a matter for congratulation that it is fast disappearing in our little Protectorate.

The old unfortunate cleavage was an extremely natural outcome of the almost unnaturally sudden evolution of the country. When the British Government first took in hand the administration of the interior there was no white population at all, and the idea of white settlement had not even been mooted; indeed the very suggestion would have been received with ridicule. The original officials were a very fine class of men of the pioneer type. Their pay was never good, and their hardships were very great. They suffered danger and discomfort from wild beasts, from savages, from disease, and through the agency of one or the 
other many a good man went out. Gradually they made some order where there had been none, gradually they evolved a semblance of authority and rule where was but tribal war and anarchy, gradually they inspired respect for the British race by the best and only means they could employ, that is, by inspiring respect for themselves. Is it to be wondered at if they became somewhat swollen in the head? No men ever had a better right. Admittedly, of course, there were occasional lapses - here and there a native roughly used or advantage taken of his credulity, here and there, and in the rarest instances, money or ivory finding its way into channels other than legitimate. Still, taken as a whole, no country was ever given a better chance by its early administrators, and the work of these earlier officials was as fine as it was arduous. Well, upon these officials, who were looked upon by the natives, and to some extent perhaps by themselves, as Little Tin Gods, came the first trickle of the tide of settlers. And what manner of men were they? Why, roughly speaking, they were just the same manner of men as those in opposition to whom force of circumstances had thrust them. Traders, prospectors, shooters, they wandered into the new country and found it good. Struck by the beauty of scenery and climate and by the obvious fertility of the soil and abundance of labour, they thought to make it their home. They too were men of their hands, men who had worked hard and lived hard; they were probably, I speak of the very earliest pioneers, nearly all good men - the inferior had gone under-and they knew it. Well when Tin God meets Tin God there is bound to be trouble. On the one hand, there was the official firm in the educated opinion that the Protectorate 
was not a white man's country, proud of the condition to which he had brought it, happy in his own position there, and most distinctly and righteously opposed to anyone who proposed to disturb either the one or the other. On the other hand, you had the settler, firm in the common-sense opinion that it could and would be a white man's country, and bitterly resenting the opinion and attitude of those who said otherwise.

At first the inevitable struggle was an unequal one. Strong in numbers and authority, the officials gave the first few settlers an extremely nasty time. Probably they, the officials in question, would be the first to admit it. However, where a country is desirable mere red tape may hinder but cannot kill white immigration, and so the settler element grew. As the sides became more equal, though actually bitterness decreased, the clamour increased, and culminated under the late Governor in certain incidents neither wholly creditable nor wholly discreditable to either side. Sir James Sadler was a kind, able, and courteous gentleman, and personally popular both with settler and official alike. There was, however, a want of breadth about his administration and an inability to recognise or even to consider the views of the non-official portion of the community which aroused intense hostility, not to the Governor himself, but to his policy. This antagonism was fed by what the People, who had taken already somewhat prematurely a big $\mathrm{P}$, considered, rightly or wrongly, to be a certain ambiguity or want of clearness in every direct pronouncement. The result was that the original and inevitable breach, which was fast healing, was rudely torn open and a series of unfortunate episodes occurred. These incidents, 
grossly exaggerated at home, did the country no good. Luckily, they are now dead and forgotten.

Under the present Governor the healing process was resumed, and at an even faster rate. Indeed, now it may be said that ill-feeling is almost if not entirely obliterated. Perhaps one thing has done as much as anything else to wipe out the memory of the past; that is the bi-annual series of games instituted by Mr. Humphrey, District Commissioner of Nairobi, between the two classes. It is manifestly impossible to feel a lasting rancour against a man with whom you have but lately fought out an enjoyable game of football or polo.

The type of the two classes may be said nowadays to have very materially changed. The day of the pioneer has gone, the day of the farmer has come. There is therefore need of a majority at least of less masterful but more intellectual and refined officials. This type we are now getting; indeed it is a matter not only of congratulation but of surprise to see the extremely high class of gentlemen who apply for the Government posts. The initial salary, $£ 250$, is very small, ridiculously so, in my opinion, when you compare the responsibilities, dangers, and discomforts which earn it. The prospects are none too good. Should the Assistant District Commissioner be spared to reach the highest honour, he may aspire to the position of Provincial Commissioner with the princely salary of $£ 650$, and if extremely lucky the pension of $£ 300$ ! Now I would urge as strongly as it is possible that these salaries be reconsidered. To raise the whole scale is perhaps too much to ask; but surely it is not too much to suggest that the Provincial Commissioner's pay should 
be at least $£$ IOOO to $£$ I 500 . Such a man is the pick of the service, and he has done 20 years' work in the tropics to reach his position. If he has married he probably has children to educate at home. Consider the work that is expected of him - the Provincial Commissioner is judge, tax-collector, military adviser, minister of education, Ambassador-extraordinary, and combines every other possible office in a territory perhaps as big as Wales and with a population of a million. From the point of view of the country is $£ 5000$ a year additional expenditure too much if it is to add the spur of ambition and hope to every official from the newest joined A.D.C. upwards in the country? From the point of view of the settler there is one thing which it is not unreasonable to ask, and that is that in a more or less entirely agricultural and pastoral country like British East Africa each newly joining official, and I here would include the very highest, should have at all events an elementary knowledge of agriculture. It does not inspire respect or confidence when an official asks what curious manner of machinery a churn may be, or calls a field of oats an unnecessarily large lawn!

I cannot leave the subject without calling attention to the universal and most generous hospitality which is extended by the officials in British East Africa to all they come across. I do not remember ever passing through a Station without being fed, put up for the night, or being offered every assistance possible by those in charge; kindnesses which can never be forgotten. Such hospitality has always been one of the most pleasant features of the country, but must, I fear, soon become too great a tax on such an underpaid class. 
Would it be too much to suggest that an entertaining allowance should be added to a salary which hardly errs on the generous side? Possibly also a free shooting licence, not to include elephants, would continue to keep up the supply of sportsmen which is so eminently desirable. On the other hand, there is an item-i.e., travelling allowance-which always seems rather in the nature of a farce, seeing that all travelling expenses are paid, and the allowance, which varies from $£ 3$ a day in the case of the Governor to Rs. 5 a day in the lower grades, is given for those very periods when the recipient is already saving money. It certainly offers a temptation to abuse.

Settlers consist naturally of many grades, classes, and races. There is the rich shooter who takes up a farm, and there is the farmer or bailiff he sends out to farm it. The first is to be welcomed for the capital he sends out, the second for himself. There is the large farming occupier like Lord Delamere. There is the small squatter. There is the sheep farmer. There is the market-gardener. There are the employers and the employees. There are the shop-keepers and the farmers. There are the British and the Boer. All are welcome.

There is only one class against whom everyone's hand is turned, and even he has his uses; I mean the land speculator. Such a one is he who, having obtained as big a block as possible, holds on with a view to the ultimate sale at an enhanced price, due principally to the labours of others. Against this man everyone's wit and energy, official and settler, are turned. It must, however, be borne in mind that in a new country like this practically everyone to a greater or smaller degree is a land speculator, and that 
the greatest offender of all is possibly the Government.

Leaving out the planters, who are a class in themselves, the great variety of settlers is due to the great variety of soil and climatic conditions. Thus round Nairobi, and in the Kiambu and Limoru districts, we have a very rich soil, well watered and timbered and having two distinct seasons, which forms an ideal block for small farmers, fruit-growers, coffee-planters, and market-gardeners. This small homestead area will increase year by year as transport facilities increase, though it is very unfortunate that it should be so largely curtailed by the unnecessarily large Kikuyu Reserve. Then there is the considerable block of country round Naivasha Lake, which, owing to its comparatively scanty rainfall, is at present only suitable, and admirably so suitable, for sheep farms. Further north again is Nakuru which is at present, perhaps, the headquarters of the cattle industry, and then again Njoro with a greater rainfall and better soil, at present the headquarters of the wheat-growers. All these changes are in a very small portion of the country and are repeated almost ad libitum throughout the Highlands.

With all this variety of occupation there are naturally an extraordinary variety of immigrants. Thus in a small population we have the public schoolboy hailing from Eton downwards (please excuse an old Etonian), the crofter, the farmer from all parts of England, the townsmen, the planter, the Canadian, the Australian, the Africander, and the Boer. It is wonderful how well they fit in. As in older colonies, there are no class distinctions. Jack is as good as his master, and thinks himself better. But perhaps we 
must make one partial exception to this general goodwill-the Boer. Now the Boer, as a Boer, is no more unacceptable in the Protectorate than in other parts of the Empire. Throughout the whole of that Empire the fight that he put up and the sacrifices that he made ere he joined it gave him a free pass to its good-fellowship. The country numbers many Boers who are not only respected but most popular. Unfortunately, owing to mischance, and I fear I must add mismanagement, they are in a minority. In 1908 there was an influx of Boers, of whom it would not be too much to say that they left their country for their country's good. They arrived pretty well destitute. Probably $£ 2000$ would have covered the worldly wealth of the whole 300 or 400. They applied for farms. Now the land regulations say, and rightly so, that any applicant should be possessed of $£ 400$ at least before he be allotted a farm. This regulation would have cut out some 95 per cent. of these applicants ; and I venture to say that, had they been Englishmen, they would have been refused. An innate sense of chivalry-and, might I add, a policy of laissez-faire?-caused their applications to be accepted and they were one and all granted farms. Even so, it might not have been a serious matter had they been scattered throughout the country, but, alas! they were all granted farms in one block in the newly opened Uasin Guishu Plateau. This plateau forms in some ways the keystone of the whole Protectorate. This is due not so much to its fertility and climate, though both are excellent, but to the fact that it is by far the largest tract of country at present opened which is not subdivided either naturally or artificially; for here we have at least two million acres of splendid land undivided by native, forest, or 
game reserves. Well, the great bulk of this splendid country was placed in the hands of a crowd of indigent Dutch, with two natural results. First, all development has been practically at a standstill, not one-tenth of the prescribed minimum of development having been done. As a proof of this statement is the fact that in IgI I there were less than I800 acres under cultivation throughout the whole plateau, a very large proportion of this being on two farms. The bulk of the inhabitants have supported themselves by the unlicensed slaughter of the once numerous game. The second ill-effect is the formation in our midst of a solid mass of utterly disloyal colonists, speaking their own language and having their own Church and who now have the insolence to demand a Dutch education at Government expense. Next to our Indian friends they form the most difficult problem in the Protectorate. Apart from this one dark spot, the future of white colonisation looks bright, and an extremely pleasant feature is to note the self-satisfaction of all and sundry. The farmer has a bad crop. All the more chance of a good one next season, says he. His flocks and herds have an outbreak of disease. $\mathrm{He}$ simply points to the inevitability of this in a new country and buys some more. Moreover, whether his farm be in the dry Kedong, on the rainy Mau escarpment, on the wind-swept Uasin Guishu, or on any other spot throughout the Highlands, he is firmly convinced and prepared to back his opinion that it is the finest and most valuable in the whole Protectorate. 


\section{CHAPTER IX}

HINTS FOR A WOMAN IN BRITISH EAST AFRICA

\section{By Lady Cranworth}

THE woman who makes up her mind that she will share the life of a settler in East Africa will still have many vicissitudes to face. Danger is no longer one of them, and discomfort, though at first one cannot fail to feel the altered conditions, is not nowadays, a very serious item. It is the third $\mathrm{D}$, however, dullness, that causes the chief worry to newcomers, or rather I would say to newcomers who have not resources in themselves. Nearly every settler is a busy man, and if, as is almost certain, he is farming, planting, or developing property, in some form or another, his whole day is occupied, and when he is not working, he is planning the next step to prosperity. This absorption in his pursuits is, I am told, a feature of all Colonial life, and is in itself a proof of the prosperity of that life. In East Africa one is lucky in that there are work and interests ready to hand, in which not only can the woman share, but which, as a rule, she can do much better than her menkind. Among such pursuits are cooking, washing, poultry-farming, gardening, household pursuits, and, in modern days, the care of the stables. There are also many matters on the farm 


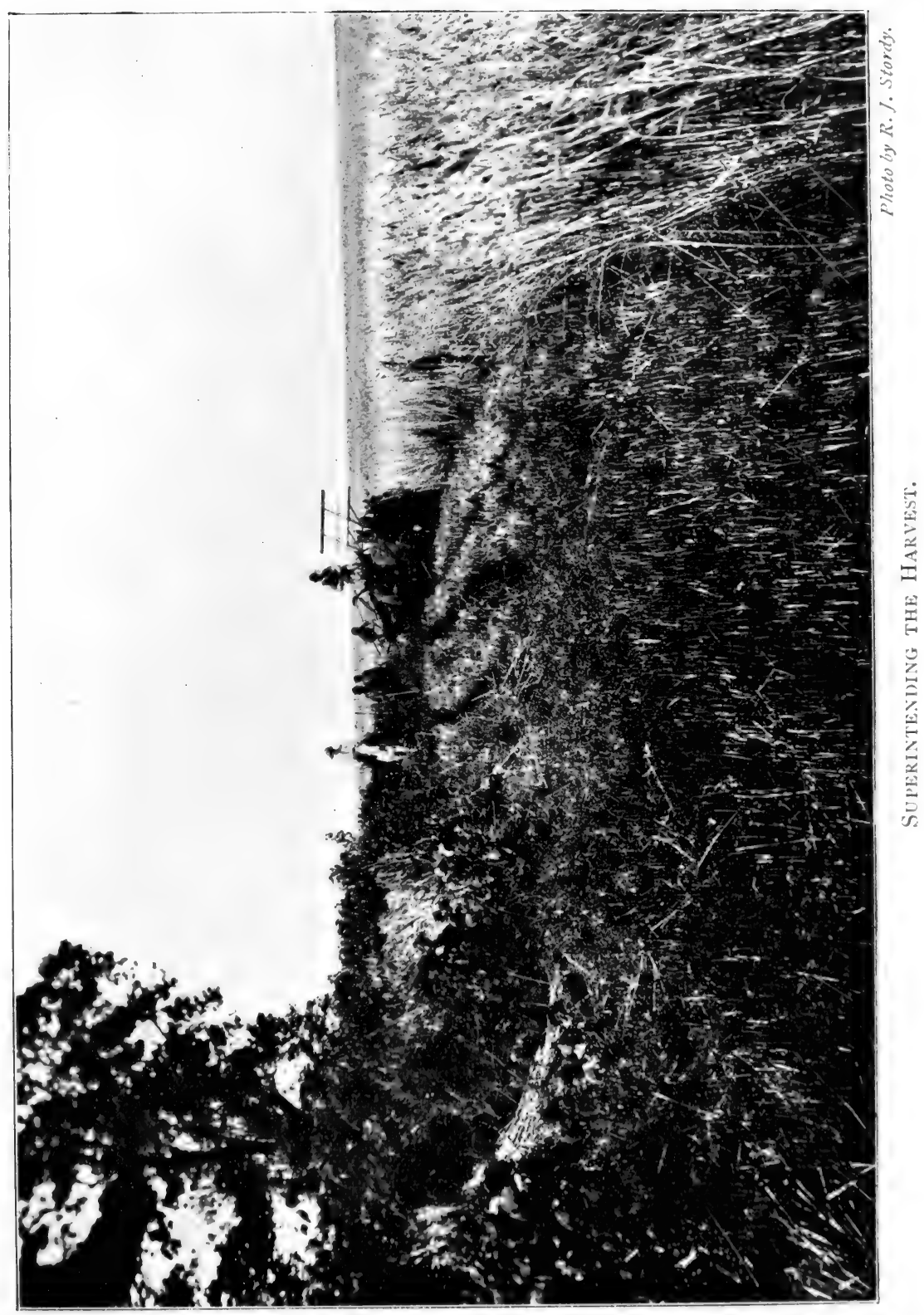



itself acquaintance with which on the part of the farmer's wife will do no harm. It will, at all events, serve to show the farm labourers that the time of the master's absence is not one which can be exclusively devoted to food and sleep. This being so, any girl who determines to try the life of a settler in the Protectorate-a decision which it is unlikely that she will ever regret-had better fit herself for that life by learning the first elements of cooking, gardening, stable management, and, if possible, a few of the simplest rules of farming. I would add house-management, were it not that the supervision of native servants is an art in itself, and one in which the qualities which make success or failure seem ingrained. One could not, for instance, learn by experience in England when is the right time to have a servant beaten for rubbing silver plate on the gravel path to clean it, and that after several previous warnings.

We will suppose that a girl is coming to settle in the country. The first question that she will ask is, "What ought I to bring out?" The answer to which, of course, depends a good deal on where she is going. Every year, however, the shops in Nairobi improve in excellence, and every year therefore the necessity to take out any special outfit either in clothes or provisions becomes less pressing.

The first point to be remembered is that although the Protectorate lies astride the Equator, it is not for the most part really a hot climate. In the Highlands the mean maximum temperature is only about $75^{\circ}$, while the nights are often quite cold ; indeed in most parts a wood fire in the evening throughout the greater portion of the year is distinctly comforting. This being so, one is far more likely to make the mistake of taking too 
many summer clothes as being suitable to the Tropics, and too few of such things as tweed skirts, shooting clothes, and thick boots, as well as a good aquascutum. It will be borne in mind that nowadays Nairobi is no longer a tumble-down collection of tin shanties, where there are but few necessities and no comforts to be bought and where prices are ruinous. It is to-day an up-to-date and thoroughly well equipped town, where there are all the modern luxuries. Nairobi has electric light, telephones, motor garages, fairly decent hotels, and, more important still, most excellent stores and shops. There is no need, therefore, to make any special preparations of any sort. Possibly the prices will seem somewhat stiff to the newcomer, but this is accounted for by the 10 per cent. ad valorem duty on imports. It must be borne in mind, too, that most of these clothes, hats, stores, etc., which one can obtain are those which experience has shown to be the best. Therefore, even supposing, as is doubtful, that one pays rather more than by importing direct, one is at all events certain of getting something suitable.

I suggest that the following might constitute a useful outfit :

Plenty of cotton and muslin frocks.

Linen coats and skirts.

Two khaki-coloured coats and skirts.

A simple divided skirt for riding about the farm.

Tussore silk shirts.

A thin riding-habit for Nairobi.

Plenty of brown boots and shoes.

Tweed coats and skirts for the rainy season.

An aquascutum. 
A large double Terrai hat or Pith Helmet-the latter can be got better and cheaper at Port Said than in London.

Two or three evening dresses of crêpe de chine, satin, or velvet.

One or two smart hats. It will be quite safe to wear these after 4 o'clock, when the sun will have lost its chief power.

Having arrived up country, about the first operation will be to collect one's staff of servants. When once one becomes accustomed to the sight of black faces, native servants will be found very fairly good. They are quite intelligent and soon assimilate any knowledge that one is in a position to impart. Unfortunately, as they learn the virtues of English domestics, they attain the drawbacks of the same with equal celerity. They have been known to sample the whiskey or to retire beneath the floor of the house with a full jam pot, there to lie perdu until it is empty; and a course of training will enable them to vie with any parlourmaid in crockery smashing. Of servants, naturally the cook is most important ; good food is at least as much appreciated and even more necessary here than in more civilised parts. Of cooks there are three varieties: the Indian or Goanese, the Swahili, and the native, whose merits come in the same order. A Goanese cook can be quite good, often with a light hand for soufflées and pastry. His tendency in the kitchen is very often also towards cleanliness. A further tendency, not so desirable, is towards drink. Experience has caused me to regard this delinquency in a somewhat broad-minded-or shall I say resigned? -spirit. As long as a cook does his work, keeps 
clean and doesn't make a habit of it, I would commend a little short-sightedness to this amiable weakness. Swahilis sometimes cook quite fairly. Natives are nearly always villainous, their repertoire being mainly confined to "roasti" and "chopsi," and their kitchens are generally in a state of filth such as makes one shudder to contemplate. The wages of a Goanese cook vary from $\ell_{3}$ to $\ell_{5}$ a month. A Swahili would be about $£ 2$, and a native anything between ros. and a sovereign. While well aware that one must cut one's coat according to one's cloth, I would suggest that cooking is one of the least desirable expenses in which to economise; a statement in which, I believe, the male sex will usually concur. The desirability of the settler's wife having herself a knowledge of cooking cannot be too strongly pointed out.

The next servant wanted will be the butler or head houseboy, on whom, to a great extent, the ordinary comfort of the home will depend. Here we are faced with the same choice, with the addition of Somalis. I would suggest that an Indian is extravagant ; moreover, one Indian in the kitchen may be good, but two Indians about the place are a nuisance. Some Somalis are good, and are essentially clean and nice-looking. Against this, however, they are certain to quarrel with the other servants; nor is honesty by any means their strong card. Let us therefore plump for a Swahili whom we ought to obtain for about zos. per month.

The cook will probably have a lad or "toto" under him, and the butler one or two, as the case may be. These three will average $10 /-$ a month.

Here, then, is a comfortable establishment for a man and his wife :- 


$\begin{array}{ll}\text { A Goanese cook } & =£ 3 \text { per month. } \\ \text { Cook's boy (native) } & =\text { IO } /-, ", \\ \text { Head boy (Swahili) } & =30 /-,, \quad, \\ \text { Two under boys (natives) } & =£ \mathrm{I},, \quad,\end{array}$

or, altogether, a total of $£ 6$ per month. This may seem a large total, and it is one that can be, and is, easily reducible by a half. It will, however, be remembered that this sum will probably represent half the total expenses of the house books, and as such is not very unreasonable.

Having got the staff together and presumably the house, furniture and stores are the next consideration. Both of the items are obtainable locally. There are both English and Indian carpenters. The latter are cheap and excellent at imitation, but there their merits end. For anything of decent workmanship and which has any last in it, it is always best and cheapest in the long run to go to the British workman. Two or three comfortable chairs are an absolute necessity, and here I would be inclined to recommend that they be brought out. Naturally also, if one has in stock such things as beds, china, linen, or plate, these had also better be brought, though they are always obtainable in Nairobi. With regard to all stores, they can be obtained locally of excellent quality and variety at little if any greater expense and with infinitely less trouble than by ordering, or even by bringing them out from home.

It is advisable to keep all stores and wines under lock and key, giving out what is required in the morning.

Gardens in East Africa become things of joy with wonderfully little effort. Certain English flowers, 
such as roses, carnations, irises, and cannas, flourish in a way unknown in these islands, and in addition many semi-tropical plants, flowering shrubs, and creepers give an added variety. Labour also is so cheap that a beautiful garden is within the reach of everyone. During the two summer seasons in Nairobi the whole of the residential quarters of the town are a blaze of colour, such as the most expensively kept up seat in England could hardly match.

It is not flowers and shrubs only that do well. Anyone situated near enough to Nairobi, any of the lesser towns, or the railway line, could make a very tidy little income from market gardening, as the demand for fresh fruit and vegetables still very largely exceeds the supply. With a minimum of skill or knowledge, good crops of peas, beans, vegetable marrows, potatoes, onions, cucumbers, asparagus, spinach, etc., can be obtained right through the year. The same applies to fruit, though these do not apparently grow so ubiquitously well and perhaps require rather more expert knowledge. Still, in many parts excellent crops of apples, plums, grapes, peaches, oranges, lemons, limes, loquharts, strawberries, and wine berries are obtainable.

I hope that I have shown enough to prove that the keen gardener need never know a dull moment, and, what is more, can actually make her hobby profitable.

Poultry farming is another branch of the farm which may very well be in charge of a woman. English fowls and English eggs are in great demand, and have risen very considerably in price during the last few years. There is something most satis- 
factory about an English egg, after the miserable apologies for the same laid by the native fowl. These latter are very little larger than a marble and are generally bad-almost invariably so when brought as a gift.

One of the first questions which any woman going out is sure to ask is to what extent the climate is suitable to European children. Well, Colonel Roosevelt laid down with the utmost assurance that children would thrive and flourish, and on the whole most people seem inclined to agree with him. One thing is certain, and that is that young children up to, say, seven or eight do remarkably well. Chubbier and healthier babies and infants than are seen in the streets of Nairobi and on many a settler's farm it would be difficult to imagine. After that age it is not safe yet to speak quite so definitely, if only for the reason that there have hardly been enough children of that age and upwards to make positive proof. There was undoubtedly a fear that the altitude combined with the heat of the sun would both tend to develop children too young, would render them nervous, and might be prejudicial to their later mental progress. Experience, however, does not bear this out, and I am certainly of opinion that, provided they be properly housed and clad, no one need be afraid of the progress of their children from a health point of view.

In nearly every settled portion of the Protectorate there is a doctor, and a good one at that, within hail. In Nairobi itself there is a beautiful European hospital fitted with every modern convenience and improvement. Still, naturally, every farm will have its medicine chest of ordinary remedies, and more 
especially such things as quinine, asperin, phenacetin, castor oil, boracic, and some good disinfectant such as lysol; also all necessary antiseptic and other bandages. A good grounding in "first aid" is almost certain to come in handy.

Finally, any woman going out to East Africa need no longer feel that she is going into a strange, wild, unhealthy country. Those days are all past. She will find friends new and old, occupations and amusements of all kinds, and if she be one of the modern out-of-door, practical girls that are fortunately becoming so common, may look forward to a thoroughly good time. 


\section{CHAPTER $\mathrm{X}$}

\section{LAND AND THE LAND LAWS}

UnTIL the last two or three years, if it was desired to bring an execration into the mouth of a settler, of course an unlikely contingency, it was only necessary to mention the Land Office.

No doubt the average settler did not, and does not yet, make sufficient allowance for the extreme difficulty of the task of fair and equitable land settlement in this country. The extra difficulty of the task may be taken as due to the extraordinary difference in quality and condition of land in every portion of the Protectorate. This divergence is so wide that it is absolutely impossible to lay down any definite code of rules that will apply to one small district or area even, let alone to the whole Protectorate.

Thus the same conditions that apply to land on the coast suitable to rubber could not possibly be made to apply to a sheep-farming area round Lake Naivasha. Yet if, as has been tried, a different set of rules entirely for coastlands and highlands be drawn up, it will prove almost impossible to say where the line of division is to be drawn, and furthermore the land on 
the shore of Lake Victoria Nyanza is at least as suitable for plantation land as any on the coast. Moreover, even if it were possible to separate entirely plantation land and agricultural land, it is hardly possible to find an area on the Highlands as small even as 100,000 acres in which the land is of so similar a character that the same legal conditions can be tortured into applying to the whole block.

It is undoubtedly this extraordinary diversity of land that proved in the past the great stumbling block to a satisfactory and uniform code of land laws; and no one can deny the very great difficulty the problem presented. At the same time, even when every allowance is made, it is to be feared that no unprejudiced person can deny that, until the appointment of the present land officer, the land laws were both conceived and administered in such a way as to delay very seriously the advance of the Protectorate. The reason of this faulty administration in the past is not far to seek. The officers in charge of the land department were not selected for their knowledge of either land conditions or even of agriculture in its simplest forms, but for proved ability in some other sphere. The heads of the Land Office were in a word absolutely ignorant of what they were expected to do or how to do it. This ignorance caused the deepest suspicion of every candidate who applied for land. $\mathrm{He}$ was at once looked on as a criminal in disguise, and the crime of which he was suspected was a desire to make money! It may not receive credence but many will bear me out that some five or six years ago or even later the suspicion that an applicant had the audacity to hope to make his holding pay would have very seriously prejudiced his chance of obtaining the 


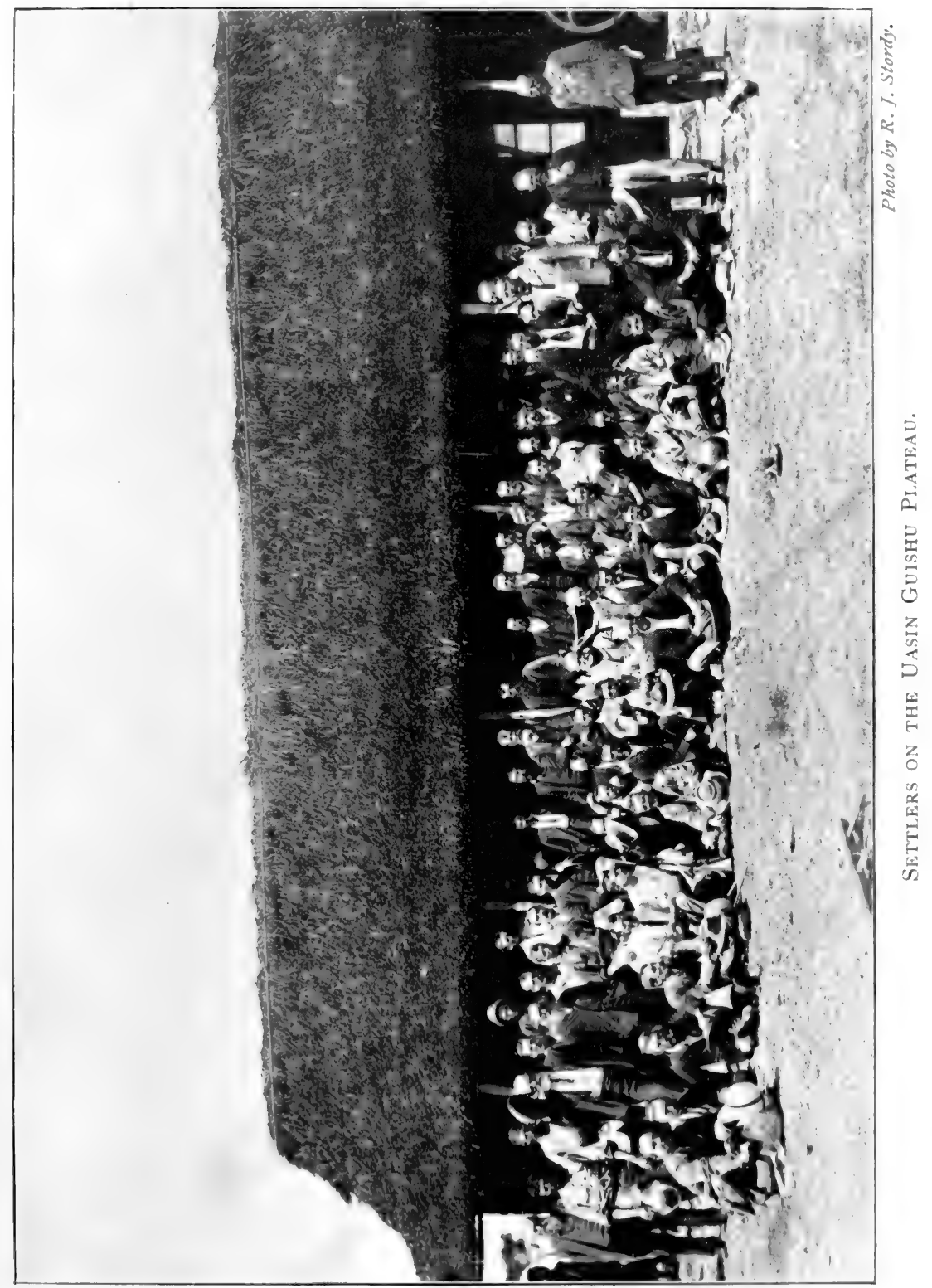



same. As a result of this ignorance and suspicion the two crying needs of the Protectorate, Capital and Colonists, were lost sight of, and the bulk of the best land, escaping the grasp of the genuine settler and investor, fell into the hands of his more specious competitor, the land speculator. As a clear proof of this, it was only necessary some twelve months back to ride down the Fort Hall Road. For the first thirty miles along this road the land has for many years been subdivided into farms; yet practically the only sign of occupation or settlement was an occasional notice warning the passer-by from shooting game. The so-called settlers, seated comfortably either "at home" or in the local hotel bar, waited for their unearned increment; while the genuine settler was forced to go and develop land and induce that increment forty miles from his market. Luckily, we have altered all that, and the administration, helped by the local Land Board, though perhaps not too kindly treated by the Colonial Office, are steadily doing their best to repair the blunders of the past.

Roughly, the conditions under which land may be obtained at present are as follows :-

As soon as an area has been surveyed, it is divided into farms ; such farms are numbered and are opened to application.

The great diversity of land is now met by subdividing it into four classes.

The area in one farm of what is termed first-class land does not exceed 900 acres.

In the case of second-class land, the maximum shall not exceed I 400 acres.

In the case of third-class land 2600 acres, and in the case of land of the fourth class 5000 acres. 
The task of classifying this land is solely that of the land-officer, and may truly be held invidious.

Every applicant, who must be twenty-one years old, must make his application in writing and must accompany the same by a deposit of $£ 5$.

Every applicant is required to prove that he is possessed of means sufficient to develop the farm applied for.

Every licence granted reserves an annual rent at the following rates :-

For land of the first class, 18 cents an acre $(3 d$.$) .$

For land of the second class, 12 cents an acre $(2 d$.$) .$

For land of the third class, 6 cents an acre ( $\mathrm{I} d$.).

For land of the fourth class, 3 cents an acre $\left(\frac{1}{2} d.\right)$.

The applicant, having applied for a farm, receives, if he is fortunate, an occupation licence for two years. This is a temporary licence, and while it runs the farm must be occupied by the applicant himself or his white agent for eighteen months out of the two years. Further, during this period of probation the farm allotted must be developed by permanent improvements to the value of twenty times the rent.

The following are the items which officially constitute improvements :-

Farm buildings, fencings, furrows, planted trees or hedges, walls, wells, drains, roads, bridges, cleared land, gardens or nurseries, water boring or water races, sheep or cattle dips, embankment or protective works, permanent crops, water tanks, fixed machinery, irrigation works. At the expiration of this probationary period, the applicant is, provided he has complied with the conditions of white occupation and development, entitled to a lease of the farm for 99 years. 
During this lease the occupant will pay for the first 33 years the rent that I have indicated; after the 33 years he will pay for the next 33 years a rent at the rate of 5 per cent. on the unimproved value of the farm ; the farm will then be revalued and he will pay in the same ratio on the new valuation for the remainder of his tenancy.

Directly an applicant has been allotted a farm, he shall pay on demand the survey dues thereon. These survey dues vary in a peculiar way from $£_{4} 6 s$. $8 d$. on 50 acres and $£ 94 s$. od. on 100 acres to about $£ 50$ on 6,000 acres. (It would apparently, therefore, be considerably cheaper to have a 100 acre farm surveyed in two 50-acre blocks!)

The British East African Government has the power of conferring a grant, at its discretion, to an individual or Company up to 15,000 acres, but the grant of a larger area must be referred home.

Moreover, an individual possessed of 15,000 acres may not acquire, by purchase or otherwise, any further area in the Protectorate.

Now on these regulations a little comment is perhaps justifiable; and if such comments are not entirely laudatory, it should be borne in mind that these conditions are the result of a Land Bill introduced in the Legislative Council of 1908 and repudiated by 99 per cent. of the agricultural population in East Africa, but nevertheless insisted on by the Secretary of State for the Colonies.

The first point to be made lies in the fact that application must be made in person for a definitely defined and numbered farm. On the face of it this is fair enough ; but where, owing, not to lack of suitable land, but of sufficient surveyors, the applicants are considerably in 
excess of the farms to be allotted, it is apt to lead either to a scrimmage at the land office doors with the object of being first applicant, as happened once to the destruction of decorum, or to the use of a lottery such as occurred on the occasion of the Londiani Allotment, a system which, besides corrupting the morals of the community by inciting to gambling, seems somewhat unfair on those who have taken the trouble to make a personal inspection and selection.

With regard to proof of means: this desirable precaution takes rather careful handling. The writer recollects a certain $£ \mathrm{I}, 000$, which, lent for one day at $\frac{1}{2}$ p. c. interest, yielded not only proof of means to many applicants but a desirable income to the fortunate owner. It would be interesting to learn on what basis was estimated the means of the destitute gang of Boers who were permitted to take up the bulk of the Uasin Guishu plateau.

As to the area of farms. In all humility I submit that they are not very fairly apportioned. The very best land is presumably that suitable for coffee and wattle. Seeing that 900 acres of such land may already be worth $£ 4,000$, it is not unreasonable to anticipate that in the course of a year or two they may well be worth $£ 8,000$. The worst class of land is presumably that fit only for sheep-grazing. Such land is unlikely to be ever worth more than IOs. an acre, and 5,000 acres is altogether insufficient for a sheep farm. Taking the first three classes, therefore, a smaller grant and a better title would probably attract more settlers, while with the last the grant might certainly be increased.

The temporary occupation licence represents an 
earnest and sustained effort to meet a difficult problem, i.e., how to regain possession of land which has fallen into what are held to be the wrong hands. There seem, however, certain unsatisfactory contingencies that are likely to arise. Thus at the end of six months and one day it is obvious that the holder of the licence, if not already in actual occupation, cannot fulfil conditions. At the same time, the Government, having given a two years' licence, cannot regain possession. The land, therefore, will lie waste for two years, or the licencee will attempt development confident in the belief that any considerable improvements effected will be a source of such embarrassment to the authorities that they will not dare to enforce a summary eviction.

With regard to the minimum amount of development required, no one can reasonably say that it is unnecessarily high; indeed a desirable or suitable settler could not very well spend less. At the same time, where so large a proportion of land-holders, possibly a majority, have not complied with this condition and have failed to do so with impunity, it is not surprising that the condition is usually regarded as somewhat of a dead letter. The majority of settlers would like to see flocks and herds included in the schedule of improvements, and on the face of it the man who keeps 400 head of cattle or 2,000 sheep is a more genuine man than he who puts up some miles of unnecessary fencing. The Government, however, urge that this form of development would lead to abuse and that the same herd of cattle would do duty on many farms. Most of those interested consider this argument unsound.

The revisal of rent is to the settler the most unpopular proviso in the lease. In their antagonism to 
this point the farmers and townsmen are for once unanimous; and it must be confessed that it is almost incomprehensible that the opinion of those who have special knowledge, and who alone are affected, should be held absolutely valueless.

The argument of the farmer is this: I take up 5,000 acres of land, the possibilities of which are unknown and which is accordingly valueless. My neighbours and I spend time and money in experiment and find out that it will grow coffee, wattle, or sisal. By our efforts the unimproved value of this land becomes $£ 2$ an acre. As a reward for my efforts I am to be fined $£ 500$ per annum! It is pointed out that when unearned increment was introduced into England, on not one but on a thousand Radical platforms it was argued that the duty was only fair where it arose from extraneous circumstances, and that to penalise a man for the improvements his own industry had effected would be grossly unjust. What was grossly unfair to the voting community in England is good enough for the voteless people of British East Africa.

The only two arguments in favour of this revisal of rent that I have heard from the British East African officials are :-Firstly, that long before the end of the thirty-three years the Protectorate will be in a position to make or repeal any land laws it may choose.

To which the answer is that it seems a pity to impose a regulation with the anticipation that it will be repealed, but which in the meantime undoubtedly repels the influx both of settlers and capital.

Secondly, that as the Ordinance is not retrospective, it actually increases the values of those farms held under the older and better conditions.

This argument is as immoral as it is unsound and 
should never have been uttered by any responsible servant of the Crown.

Then what does the settler want, if he is not in love with those regulations which exist at present? Here one must tread delicately: for obviously it is easier to be unanimous in opposition to a system which has been tried and found wanting, than in support of one which has yet to be tried.

It is pretty certain, however, that the bulk of the population would welcome the following :-

That increased precautions should be taken that grants of land should only be made to genuine settlers and investors.

That when once the grant was completed, such grant should be on the terms of freehold or perpetual quit-rent.

That the main object of the land laws should be to encourage an influx both of colonists and capital.

That white occupation should be the most stringent of all conditions.

That while grants should in the main be restricted in size, large grants could be made to companies or capitalists.

Provided-that white occupation be not diminished thereby and that an increased minimum of capital be required.

Thus if 5,000 acres demanded a minimum expenditure of $\Varangle 500$, Io,000 acres should require a minimum of $£ 2,000,20,000$ acres an expenditure of say $£ 6,000$, and so on.

That all such cases should be judged on their merits and that as far as possible the aim should be to prevent too rigid a code prejudicing the development of the country. 
That once a grant has been made it should be completely negotiable, and that as far as Europeans or Americans are concerned there should be no restrictions either on seller or buyer.

That there should be a large increase of surveyors, and that the system of rapid allotment should be employed as far and as fast as possible with a view to settling up the whole habitable portion of the Highlands.

These, as far as one can judge both from hearing set speeches and informal conversations, form the basis of a system which would be generally acceptable. A by no means negligible minority would perhaps be opposed to large grants in any shape or form. The reason of this opposition I take to be the scant measure of progress or development undertaken by two large companies already in existence. No one wishes to defend the companies in question, and indeed it has always been felt to have been a curious if not an extraordinary thing that a Government which always set itself against any but the minimum grants and turned away many thousands of pounds of capital which would have come into the country with a slight elasticity of the regulations, should have given away I,O00 square miles of splendid land with most inadequate security for any reasonable development. At the same time, I believe that a majority do not wish to banish entirely the goose, but rather to make certain that she shall lay a satisfactory supply of golden eggs.

I hope that nothing said in this chapter will be taken as a reflection on the present land officer or his staff. Indeed, I cannot express too highly the admiration with which the sincerity, ability, and patience exercised by them have always filled me. 
If, as I have suggested before, some of the earlier land officers were ignorant of the first elements of land, land settlement, and land tenure, they might well retort that this ignorance was shared to at least an equal degree by the majority of the earlier settlers.

The buildings occupied by the land officers are most insanitary, and the heat in the corrugated iron hut that does duty for a land office is at certain seasons of the year most oppressive. The class of questions dealt with in this office are not only most perplexing and difficult themselves, but are often presented in person by an angry, incoherent, and perspiring applicant. Yet I have never known or heard of anything but the utmost civility accorded to the applicant, and the utmost pains taken to find a loophole in the law which will give a fair solution to his case. 


\section{CHAPTER XI}

AGRICULTURAL PROSPECTS

THE three prime questions that most would-be settlers have to ask consist of: What of the climate? What of the sport? What of the possibilities of making money? It is here that we would deal briefly with the last question. Up to the last three or four years, it was necessary to merge the direct answer in a golden mist of future speculation. A great many projects looked favourable, and there were endless possibilities about others; but of a probable fortune and an assured income there was no certainty, the truth being that there was no great amount of capital invested in the Protectorate, and very little produce was being grown and exported. As a consequence, every man lived on his neighbour, and it tended rather to take the gloss off a successful sale or deal to feel that it was done at the expense of a personal friend or perhaps rather one who should have been of that category.

Luckily, in the last few years this has all been changed. Capital is flowing in, and, better still, exports are flowing out. Land is going up every day and has now an actual and negotiable value, and not one existing solely in the mind of the proprietor. It is nowadays possible to say to the intending settler: 
"This will grow and that will grow. You can send them to such and such a country and sell them for such and such a price; and the cost of production should be roughly so much." This admirable result is due partly to the patient and persevering efforts of the Government -more especially perhaps of the Agricultural department, who have quietly and steadily worked and experimented, often in the most disheartening conditions and with a minimum expenditure, to achieve this end. But still more is it due to all the first-comers, those who sowed where others will reap, who worked and experimented with their money and with their own hands, who faced cheerfully each new disease, each new pestilence with but small hope of success, and who undeniably, until the last few years, did not receive the right support and encouragement from those who should have given it. Of such men Lord Delamere comes undeniably first.

Those settlers who have arrived in the last few brighter years are apt to take exception to the large grants of land obtained and still larger areas possessed by some of the first arrivals. They are apt to forget that these men have done the spadework, or rather represent the survivors of those who have done the spadework, and without their efforts there would have been little chance for the fortunes which later-comers like myself hope soon to obtain. The first comers all sacrificed money and comfort, many sacrificed health, and more than a few life. Those who have stuck on are now beginning to see some slight return in the increased value of their holdings. It ill becomes us to grudge it them. There are, however, one or two large early grants and concessions to companies which hardly stand on the same plane. 
The agricultural portion of the Protectorate may be divided into the temperate and tropical parts, the former consisting of the bracing and breezy Highlands, the latter of the fertile but unhealthy - that is, comparatively speaking-areas along the shores of the great lake, along the coast and on the banks of the Tana and Juba rivers. With the latter, want of knowledge and want of time will prevent our dealing. Suffice it to say that much of such land will compare in fertility with any part of the globe, that over a considerable proportion of it labour is reasonably plentiful, reasonably good, and reasonably cheap, and that for a planting country the conditions of health are distinctly favourable. Should a settler have any spare cash to invest outside the work under his immediate control he might do worse than invest it in some rubber, cotton, or perhaps preferably cocoanut plantation. He will be able to pay periodic visits from his healthy home and see that operations are being honestly and methodically carried out. Undeniably a fortune can be made, or lost, quicker in plantation produce than in more temperate crops.

In the Highlands, which may be said, in the roughest and broadest sense, to comprise all land above an elevation of $4,000 \mathrm{ft}$., farming prospects may be divided into those of livestock and of agriculture ; and the latter may again be subdivided into those of seasonal and permanent crops. Into which the intending settler had best be advised to enter depends on his inclination and knowledge, on the amount of capital that he has available, and in what area he finds it practicable or possible to get land.

The more important and proved lines that the Highlands afford are: 
A. Permanent Crops.

Timber.

Sisal.

Coffee.

Wattle.

Fruit.

B. Seasonal Crops.

Wheat.

Beans.

Maize.

Barley.

Oats.
Linseed.

Potatoes.

Tobacco.

Ground-nuts.

Chillies.

C. Livestock.

Horses.

Ostriches.
Cattle.

Sheep.

Pigs.

And of these the settler can take his choice, selecting one or more or else contenting himself with a mixed farm.

From a colonising point of view the ultimate aim of the Protectorate must be, not only to get the highest possible value in the annual production, but to carry the largest possible white population that can be supported with a reasonable average prosperity. This goal is generally recognised as desirable; but as to the steps that should lead towards it there is great diversity of opinion. Possibly the future will shape itself on the same lines as in the best portions of our Australian Colonies. Holdings on the line and round townships will tend to be small and agricultural. Land of similar quality but remote from railways or commercial centres will be subdivided into larger blocks for cattle or sheep. Provided that all goes well, the success of the sheep and cattle will justify the extension of branch lines; 
and as these lines go forward the large blocks will be voluntarily or even compulsorily cut up into small and agricultural holdings. I do not think that the alienation of large tracts in the out-districts need raise too much apprehension in the minds of the more radically inclined, or too high hopes in the minds of the more conservative or acquisitive; provided always that proper precautions for adequate development be taken.

Such considerations for another generation need not affect the settler of the present day. At the present time, he has his choice. $\mathrm{He}$ can acquire a small agricultural holding near Nairobi, and besides making a nice and comfortable living without any very great exertion, can enjoy all the comforts of civilisation. Such small holdings in favoured places are perhaps the most certain of any to show an increased value. Four years ago the average price of land within ten miles of Nairobi was not more than ten shillings an acre; now it is certainly not less than three pounds. Perhaps, however, the intending settler has no use for civilisation, and has developed in him that desire for the possession of mud in large quantities which is so marked a characteristic of Englishmen, not only as a race, but as individuals. If so, he can still buy or take up a large block where his nearest neighbour will be ten miles off and the nearest apology for a town fifty. His profits will take longer to acquire, and his setbacks will be frequent; in the end, however, success is certain and assuredly he will have earned it. If, again, he has capital, a thirst for wealth, and a talent for organisation, he will be well advised to embark in the growing of some such permanent crop as sisal or wattle. These crops take both time and money to 
put on the market, but after some six years will, or should, well repay the investor.

The great and outstanding advantage which distinguishes the Highlands of the. Protectorate lies in the fact that, generally speaking, there are two seasons. This circumstance is of even more value than the deep and splendid soil, which is almost ubiquitous. It helps both the annual and permanent crops. Growers of the former can anticipate the double harvest, with its added work and added profit. Should one crop fail there is not the same long, dreary period of waiting to recoup losses. Permanent crops, such as wattle, are helped by the double growth and the consequent early maturing of the product.

The great disadvantage with which we contend lies in the variation of the rainfall, not only as regards quantity but as regards period. The rains hardly ever fail. Indeed, I believe that during the last twenty years there is only one instance in which the long rains practically failed altogether; and during that period there is no recorded instance of the total failure of the short rains. There have, however, been numerous instances of the rains being too light to ensure any but the shortest of crops, and also others when the rain has come prematurely and in such heavy quantities that it has been impossible to sow the whole areas prepared. It is this uncertainty-although even this compares favourably enough with the vagaries of our English climate-that is tending to the increased proportion of long or permanent crops.

In the short and by no means comprehensive list which is dealt with it must by no means be thought that the industries touched on in any way exhaust even the assured products of the Highlands. And as I 
have said of unassured and speculative crops or products their name is legion. With regard to the many attractive and speculative projects to which each and every newcomer will certainly be introduced, I can only pass on a piece of advice given to me, and which I believe to be no bad guide. Take a piece of paper and jot down the incomings and outgoings which appear likely to occur in the suggested scheme, stating them as severely against the success of the venture as seems possible. Then multiply the outgoings and divide the incomings by two. If the scheme still shows a substantial profit, it may be worth while going into carefully. In some ways it would be by no means to be regretted were our assured successes less numerous. Delightful as is the great variety of products that do well, it would in so small a country be not entirely to the bad could the whole of our energies be focussed on some few definite lines. 


\section{CHAPTER XII}

SISAL HEMP AND BLACK WATTLE

Sisal Hemp.- The cultivation of sisal in the Protectorate may at last be said to have become one of the proved industries of the Highlands. Messrs. Swift and Rutherford, the pioneers of sisal planting in the Highlands, erected their machinery during the course of the last twelve months, and are now turning out about two tons of fibre daily. The price realised is a satisfactory one, and leaves a very good margin of profit indeed. It may be said without cavil from any quarter that success was never better earned than in the case of these two gentlemen.

As this book has no pretence whatever to be a scientific work, it is not the place to enter on a dissertation as to the best methods of planting, growing, or decorticating the fibre. The subject is, moreover, an extremely thorny one, since sisal grows in such very different circumstances and climatic conditions that no definite rule for any but the most circumscribed locality can be laid down. It stands to reason that any man or company prepared to risk a considerable amount of capital would before so doing carefully study the conditions on the spot.

There are certain great advantages in the Highlands 
which enable sisal growers to compete on singularly favourable terms with their rivals, not only on the coast, but in German East Africa, and this notwithstanding the extra freight with which they have to contend, both on the fibre which is sent down and also on the machinery which is brought up. The first of these advantages is cheap and comparatively abundant labour. In the Highlands labour varies from 3 to 7 rupees a month as against io to 16 rupees on the coast or in German East Africa, and when the very large amount required is considered it will be realised that the saving under this head alone should more than counterbalance the difference in freight. Again, in the Highlands oxen can be freely used for ploughing, another very considerable saving both in time and expense. The third, and perhaps outstanding, advantage, lies in the catch-crops, more especially of beans, that can be produced. Rose cocoa or Canadian Wonder beans can be grown between the rows of plants for the first two years and can not only be sold at a very good figure, but also serve to keep the ground clean and free from weeds. Thus an acre of sisal will be actually brought to a producing stage in the Highlands entirely free of cost instead of having incurred, as elsewhere, an expenditure of two, three or even four pounds. Again, though hardly capable of being expressed in pounds, shillings, and pence, the advantage of a healthy climate for the white overseers is difficult to over-estimate. It tells a tale both in hours of labour and in rate of pay, and in quality of the brainwork expended.

In selecting a suitable area for sisal growing several considerations will affect the settler : such as proximity to the railway, presence of water, suitable site and 


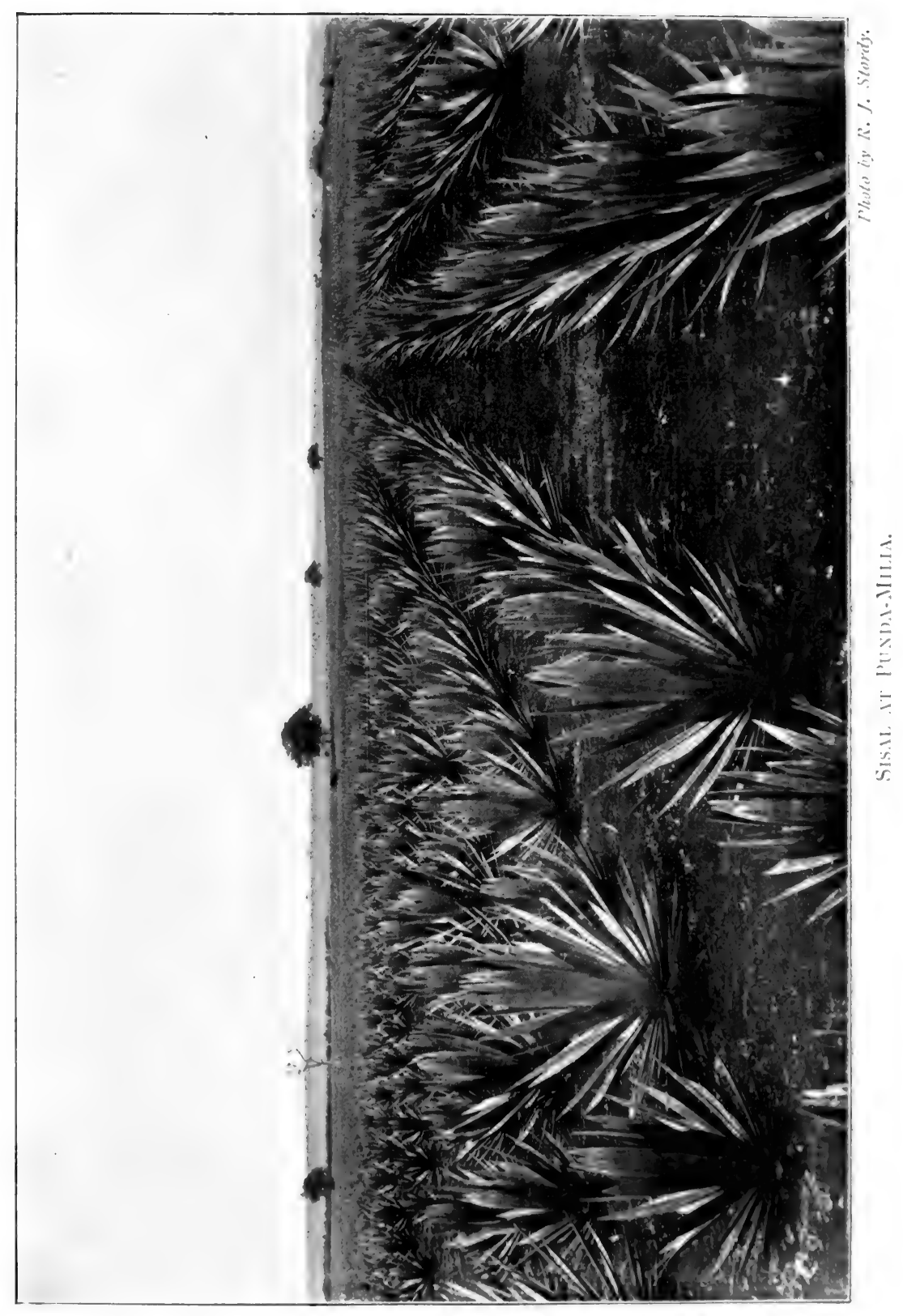



soil, and, most important of all, a good supply of local labour. An ideal spot would be three or four thousand acres of red soil, with little clearing required, sloping gradually down to a stream, with possibly a small waterfall thereon. This area would touch the line on one side and be bounded on the other with a native reserve. If I had to distinguish, I would suggest that labour is the most essential consideration, and a compact configuration of ground with gradual and easy slopes the second.

In British East Africa, sisal poles sooner than in the Bahamas or Yucatan, from five to five and a half years being the accepted period. This fact, though at first the premature poles caused somewhat of a panic among planters, is in reality all to the good. The effect is that all the leaves must be cleared from the plants in two and a half to three years instead of in a longer period. Provided, therefore, that the leaves have arrived at a marketable length, which is in fact the case, it means economy in space, a great desideratum. The number of leaves number between 200 and 220 , which is an unusually good average; indeed in German East Africa 160 is held to be more than respectable.

The principal point that has worried sisal growers has been the best distance between each planted sucker or bulbil. The original idea was to plant sufficiently far apart to enable the crop to be renewed by the growth of suckers between the original rows. To attain this result 6 feet by 9 feet or an even greater interval was desirable. It was found, however, that the second or intermediate crop was short of fibre, owing presumably to the exhaustion of the ground. Nowadays, therefore, it is held desirable to plant as 
closely as possible without interfering with the working of the cutters, and when the crop is completely harvested to allow the ground to fallow for one year at least. For such a purpose 6 feet by 6 feet, or possibly closer, is to be recommended. This plan, of course, necessitates the taking in of an increased area, a fact to be borne in mind in selection of site. Obviously this latest method is to the comparative advantage of British East Africa, where the actual production of a full-grown sisal plant on fresh ground implies no additional expenditure (i.e., will be paid for by the catch crops).

The amount of water necessary for the efficient washing and decortication of fibre is another debatable point. It may be said, however, I hope without fear of contradiction, that 2,000 gallons a day is ample for an output of two tons, and without doubt there are methods by which this amount may be very materially reduced. Machinery is both cheapened and improved nowadays, but is still the principal outlay to be faced. To deal with the produce of 300 acres annually a total initial cost of say $£_{3}, 000$ must be faced. A thousand acres is about the smallest area which will economically support a factory, bearing in mind a possible drop of prices in the future. For such an area a capital of $£ 5$, 000 would not come amiss, though some of the best authorities place it at a considerably lower figure.

Under present conditions, sisal fibre can be placed on the market from suitable localities at about $£ \mathrm{I} 3$ per ton, including interest on capital and any and every contingency and there seems no real reason to suppose that the price will drop below $£ 20$. It cannot too strongly be insisted that organisation or the lack of it spells success or failure, and that 
attention to this end means everything. A strong point in favour of the industry lies in the fact that a regular and constant supply of labour is required. This fact places it at an advantage with those industries which require a lot of labour at one season only. The prospects of sisal in British East Africa look singularly rosy.

Black Wattle.-The cultivation of Black Wattle (Acacia decurrens) has in the last two or three years received much attention, and bids fair to supply one of the premier products of the country. As is, of course, well known, black wattle is grown partly for the timber but mainly for the bark, from which a high percentage of tannin can be extracted. The source from which the bulk of the bark imported into Europe came was originally Australia; but nowadays this country has been, to a large extent, superseded by Natal. The exports from this country have risen from $£ 89,000$ in 1906 to $£ 192,000$ in 1909 , with a much greater increase during the last few years.

Among the various questions that must be asked with reference to the economic cultivation of wattle in the Protectorate are emphatically the following: (I) Are there areas in which wattle will grow and come to maturity, and if so, where and in how long? (2) Will the bark contain an adequate percentage of tannin, and will it be of marketable quality? (3) Is there a ready and certain market for the bark? (4) Does the same apply to the timber? (5) Is there any fear of over-production?

The first question can at once be answered in the affirmative. There is a very considerable extent of country over which wattle will grow and grow well. In Natal wattle grows best in what is known as the 
mist belt, a stretch of country some $6,000 \mathrm{ft}$. high with a rainfall of about 60 inches per annum, and a long period of dull misty weather, and the tree especially favours light, well-drained loams. Such conditions are found with us, more especially at Londiani, Limoru, and parts of Kyambu, and it is possibly here that wattle grows the best. At the same time, with us, the tree is not so particular. It is growing splendidly on the plains at Njoro at a height of 6,000 ft., and again with Mr. Dickinson on the Ndarugo river towards Fort $\mathrm{Hall}$ at a height of 5,000 ft., while the bark from trees in Nairobi itself, and growing in shallow soil, has at $3 \frac{1}{2}$ years of age shown a percentage (over 43) of tannin which surpasses anything in the Protectorate or elsewherethis too with an average rainfall of less than 40 inches. Growth in the Protectorate is very rapid, owing both to the soil and to the double season; and trees are ready for stripping in five or six years at the most, as against six or seven in Natal, and seven or eight or even longer in the Transvaal. The percentage of tannin in the bark has proved equally admirable. The average throughout Natal is about $34-36$ per cent. ; in Australia it is about $38-40$ per cent. In February, 1909, Mr. D. E. Hutchins, Conservator of Forests, and one of the first to realise the possibilities of wattle culture in the Protectorate, sent five samples of bark to the Imperial Institute for analysis. The highest percentage, as mentioned, came from $3 \frac{1}{2}$ years old trees in Nairobi, while the lowest, which came from a height of $7,500 \mathrm{ft}$. on the Aberdares, showed 35.8 . Nor was the quality otherwise than good. Prices of from $£ 8$ to $£ 8$ i 5 s. per ton were quoted, a price which must be regarded 
as eminently satisfactory, more especially as some of the samples suffered in preparation. With regard to the yield per acre, it is early yet to speak with any certainty. In the Transvaal the yield of bark is put at from four to six tons. In Natal the average is somewhat higher. Mr. W. B. Jackson considers that a low estimate of our crop would be seven tons to the acre. Let us hope that he is not unduly sanguine.

Before entering on a crop which requires so long a period to bring to maturity, the settler will naturally want to know what chance there is of over-production and. consequent fluctuation of price. To this question it is not possible to return so positive an answer as to the previous two. An answer received early in I9I I from the Imperial Institute, in response to a query from our Agricultural Department, was guarded in tone, and showed a natural disinclination to indulge in prophecy. Two reasons for this reluctance are given, the former that chemical substitutes can be and are used if there is a shortage of bark, the latter that Germany is our principal customer, and that extensive plantations are in process of formation in German East Africa, to which preference will naturally be given. One significant fact stands out, however, and that is, that the increased production from $\mathrm{Natal}$ has had no effect whatever on the price, which has remained for five years at a very steady figure. A consideration of all the circumstances tends to the opinion that the larger the area under wattle, the more certain will be the demand, though conceivably there will be considerable fluctuations in the price.

As regards the sale of timber, we look like being at a distinct disadvantage compared with Natal, since 
there wattle timber has a ready sale, being used for props in mines; further, the wood is used for fuel by the railway, for which purpose it is reported excellent. In British East Africa we have as yet no mines, and the railway reports unfavourably on wattle fuel. It may be assumed, however, with confidence that a State-owned railway will see their way, and indeed must see their way, to utilise the timber, even if it be inferior, which is itself an extremely doubtful point. It is possible that it will make the whole difference between the success and failure of the industry.

The man, or company, who determines to go in for wattle will proceed to choose his ground. And here it may be said, as is so often said of farming land in England, that the best land is generally the cheapest. In the long run it will be found best to pay a high price for an area which has all the essentials highly developed than to pay a reduced, even a considerably reduced, price for that which is deficient in some or other desired characteristic.

The ideal situation would be an area of, say, 4,000 acres at an elevation of $7,000 \mathrm{ft}$. where there are considerable periods of mist. It would lie alongside the line. This is a vital consideration in a bulky crop of comparatively low value; and, indeed, unless in exceptional circumstances, the cultivation of wattle at a greater distance from the line than twelve miles could not be recommended. The soil would be deep, loamy, and nicely drained. The rainfall would be between 50 and 70 inches. Clearing would be an easy task. Labour would be plentiful in the vicinity. There would be water-power, fuel, and an absence of the mischievous species of game or mosquitoes. For 
such a piece of land, if procurable, $£ 5$ an acre would be no excessive price.

The site selected, an area will be ploughed annually, off which a crop will be taken. The wattle will then be sown in situ, filling up failures from a nursery. In Natal the rows are usually I $2 \mathrm{ft}$. apart with $3 \mathrm{ft}$. between the seedlings in the row. Possibly $8 \mathrm{ft}$. by $8 \mathrm{ft}$. will answer better in this Protectorate, or even $6 \mathrm{ft}$. by $6 \mathrm{ft}$., though the latter system necessitates thinning. Before sowing, the seed should be placed in a bucket, boiling water poured on it and allowed to stand for 24 hours. It will then be apt to stick together, but can be separated, if necessary, by washing in cold water or mixing with sand. The bed for the seed is made with a sharp stick, a hole a couple of inches deep being made into which three seeds are dropped. If two or three seedlings make their appearance, only the strongest is allowed to stand. One pound of seed per acre should be sufficient.

The trees will probably be stripped after four years' growth, and for the stripping several methods are adopted. That recommended nowadays is to ring the tree as high as the stripper can reach, and tear the bark downwards. This system ensures that the bark be taken right down to the roots where it is richest in tannin. The trunk is then cut, the branches are trimmed, and the bark is then obtained from the higher portions.

The proper drying and preparation of the bark is all essential. If the weather be set fair it may be dried out of doors, but in our country it will probably answer best in the long run to erect sheds of sufficient size to enable all drying to take place under cover.

After the stripping, and when all the serviceable 
timber has been removed, the brushwood, etc., may be placed round the old stumps and fired. This will prevent the cut stumps shooting. As the seedlings grow up they will again be thinned out into rows and the process repeated. The variety of black wattle which is apparently best suited to British East Africa is var. Mollis. Care should be taken not to have any ornamental Silver wattles (var. dealbata) in the neighbourhood of plantations.

$U_{p}$ to the present wattle has been satisfactorily free from disease or pests. A small nocturnal beetle has made periodic attacks on the foliage ; but, luckily without lasting effect. A serious danger lies, as elsewhere, in grass fires. A sufficient clearing should be made not only all round the plantation, but also between different blocks.

It may be stated with confidence that, in the most favourable portions of the Protectorate, wattle growers need not fear competition from any portion of the world. 


\section{CHAPTER XIII}

WHEAT, MAIZE, COFFEE

Wheat has been in the past both a considerable success and a considerable disappointment, and to what extent the amount to be exported will increase is at the present moment a matter of doubt. But for one drawback, the crop in certain districts is eminently desirable. It is cheap to sow and to harvest, and with the use of modern machinery requires comparatively little native labour. The crop under normal conditions is a heavy one, and is readily disposed of either at Nairobi for local consumption or for export. The great deterrent, as in many other parts of the world, is rust, which to a greater or lesser degree has attacked every one of the hundred varieties of wheat experimented with.

Njoro, on Lord Delamere's and the neighbouring estates, has been the chief centre of the wheat-growing industry, there being some 5,000 acres under wheat in the neighbourhood of the station. The course of wheat-growing in this district has run somewhat as follows. The first areas ploughed up were planted with two or three different varieties of wheat, of which "Gluyas" formed the principal. The first crops were excellent, in some cases more than 30 bushels to the 
acre were obtained, yielding a net profit of over $£_{3}$ an acre. There was little, if any, sign of rust. The next year a considerably larger area was put in, and one or two new varieties of rust-resistants, notably Bobs and Rietti, were put in in small portions. This year the Gluyas was considerably affected by rust, the Bobs hardly injured, and the Rietti untouched. The crop as a whole yielded another satisfactory profit. The third year the area was planted principally with Rietti, partially with Bobs and Gluyas. The Gluyas was very badly affected and the Bobs considerably damaged, while even on the Rietti spots of rust began to appear. This history, though not a definite one, illustrates the course the disease appears to take. Each new resistant holds out for a period and then finally succumbs. The following theory has been propounded to me by perhaps the best practical authority in the Protectorate. A particular variety of wheat has especial rust-resisting qualities. It is sown, and with a favourable season resists the insidious advances of the rust fiend. After one or more seasons, a time comes when its inherent robustness is weakened either by an unsuitable season, or by the attacks of some insect pest or by the exhaustion of the phosphates in the soil. It can then no longer successfully combat the assaults which always continue. The resistance breaks down in certain plants, and they act as stepping-stones to enable the rust-spores to accustom themselves to the normal sap of all the plants of that variety of wheat. When this process is thoroughly accomplished, the variety of wheat in question becomes worthless in the Protectorate. Up to the present the wheat which has made the longest and most successful defence is Rietti, which, unfortunately, is not a very high-class wheat or one 


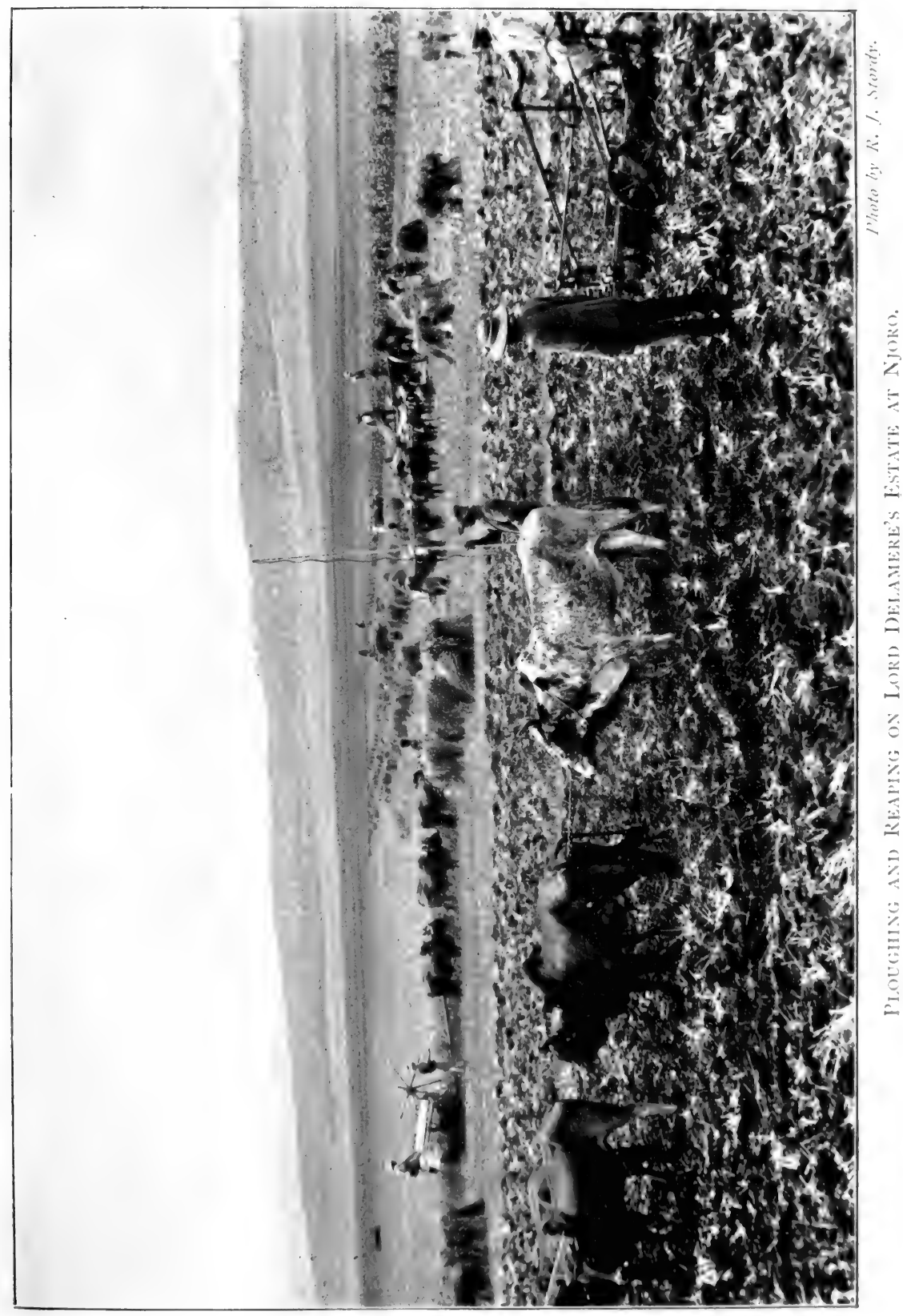



essentially suited to our requirements. Rietti does not give a very high yield, nor do the reports from England speak too highly of its milling qualities; though locally it is considered excellent. The way to fight and finally defeat rust lies obviously in breeding a wheat which will prove resistant in the local conditions, and it may even prove necessary to breed a succession of varieties so that a new variety will be ready to replace the last should it succumb. On this work Mr. G. W. Evans of the Agricultural Department has been busily employed for two years; and it will be borne in mind that owing to the existence of the double season this is equivalent to four years. It is reported that there is already one rust-proof hybrid in existence, a matter of congratulation both to Mr. Evans and the wheatgrowing settler.

In a very minor degree insect pests have caused trouble-two varieties in particular being responsible for considerable damage. The first is a small variety of beetle which attacks the young wheat and chews or sucks the sap just below the ground level. The beetle, lying concealed by day, emerges in countless numbers by night and in one case destroyed 200 acres in a few days. In this case they were tackled with singular energy and skill by Mr. Anderson, chief entomologist to the Agricultural Department, and completely demolished. This end was accomplished by the broad-casting of poisoned bait (Paris green, bran, and sugar). It was estimated that over two million beetles to the acre were destroyed. The second pest was a species of green fly which attacked the young plants. The damage, though serious, was not so disastrous as in the case of the beetle. Unfortunately, no absolute means of annihilation has yet 
been discovered, though bush-harrowing has proved a considerable mitigation. It is not unlikely that the pests in question are the result of two or three seasons of unusual drought and will not recur in years of more normal rainfall.

It need not be thought from these somewhat gloomy remarks that for the newcomer to embark in wheat-growing would be an act of folly. That is not so. Nearly every farmer who has grown wheat in suitable localities and on a sufficient scale has done so at a profit. Even under present conditions there is every probability of two or three good crops when new land is broken up. Such crops will pay for all the labour involved and give a satisfactory profit in addition. After this, should rust occur to such a degree as to prohibit another wheat-crop, even with a change of seed, the land will be in excellent condition for an alternative crop.

Maize Growing.-During the years 1909-10 the idea of growing maize for export was promulgated and for a period flourished exceedingly. It is well known that the export of maize has done a great deal, in fact nearly everything, to increase the prosperity of South African farmers, and those who hoped most from the effects of organised export from the Protectorate, and indeed were responsible for the maize boom, based their expectations on their experiences in the south. As so often happens, in deducing an analogy from the different country certain factors were left out. South Africa is a huge, and with certain notable exceptions not very fertile, stretch of country none too well watered. Instead, therefore, of having to choose, as in British East Africa, from a variety of products that all grow well, farmers generally speaking are only too 
thankful to find anything that will grow at all. This product they get in maize. Take the Transvaal. Generally speaking, a maize crop can be grown on new land for four or five years and will yield during the same period an average crop of between four and five bags. There is nothing very great about that, but the crop is certain and diseases are very few. Consequently, the Transvaal Government determined to use every power of organisation and management to ensure the farmer a small but certain profit on his crop at an average price. Accordingly, arrangements were made and contracts entered into whereby the railway freight was reduced to I Is. $4 d$., and the sea freight to I $4 s$. a ton. All other charges, including ordinary insurance, were effected at $4 s .6 d$. This in all makes a total charge of 2s. $8 d$. a bag, for which sum also Government undertook to collect payment. Thus all the farmer had, and has, to do was to turn up at the station and hand in his bag of maize, to receive the market price less 2s. $8 d$.

Now in British East Africa the average crop is more like eight bags than five, and, moreover, in many parts we get two crops in the year. It was therefore felt, and rightly so, that though our freights would always be higher than theirs, yet our farmers could still compete on favourable terms with those in South Africa taken as a whole. Two points, however, were temporarily lost sight of. The first is that we have not the scope of ground available to provide a sufficient surplus stock of maize to induce ship-owners to lower their freights to a reasonable figure. The second and perhaps more obvious consideration is that we can grow a variety of very much more valuable crops.

The local demand for maize is so great that large 
areas, comparatively speaking, more especially of native land, will always be under maize. When this crop is above the average, there will be a considerable surplus to export. Further than this, maize export is hardly likely to become a great factor in the prosperity of the country. Our land is too valuable. According to Mr. A. C. Macdonald, in a very lucid and interesting lecture given in 1910 , the average price to be anticipated in London is about $£ 53$ s. a ton, though of course it has often been higher. The farmer can grow maize and deliver it at Kilindini, including a reasonable profit, for $£_{3} 16 s$. The matter of freight, therefore, is still one of adjustment.

There is no great secret with regard to maize growing beyond the usual maxim of plant early and cultivate well. Maize is a surface plant and is best suited by a good deep loam. While it likes plenty of moisture, it cannot stand being waterlogged. It is fairly greedy in the soil and after a certain period must or had better be grown in rotation with some leguminous crop. In those parts of the Protectorate where it is possible to get two crops, it stands to reason to plant an early ripening variety during the short hot season succeeding the little rains. Such a variety would be the Champion White Pearl. During the long mild period succeeding the big rains Hickory King is usually grown.

Coffee.-Every year it becomes more apparent that the cultivation of coffee will prove one of the chief sources of the Protectorate's wealth. There are several localities where coffee grows well and crops heavily, and as yet the Protectorate has not been visited by disease. Further, the quality is good and the price shows a steady upward tendency. From $£_{4} 45$ 


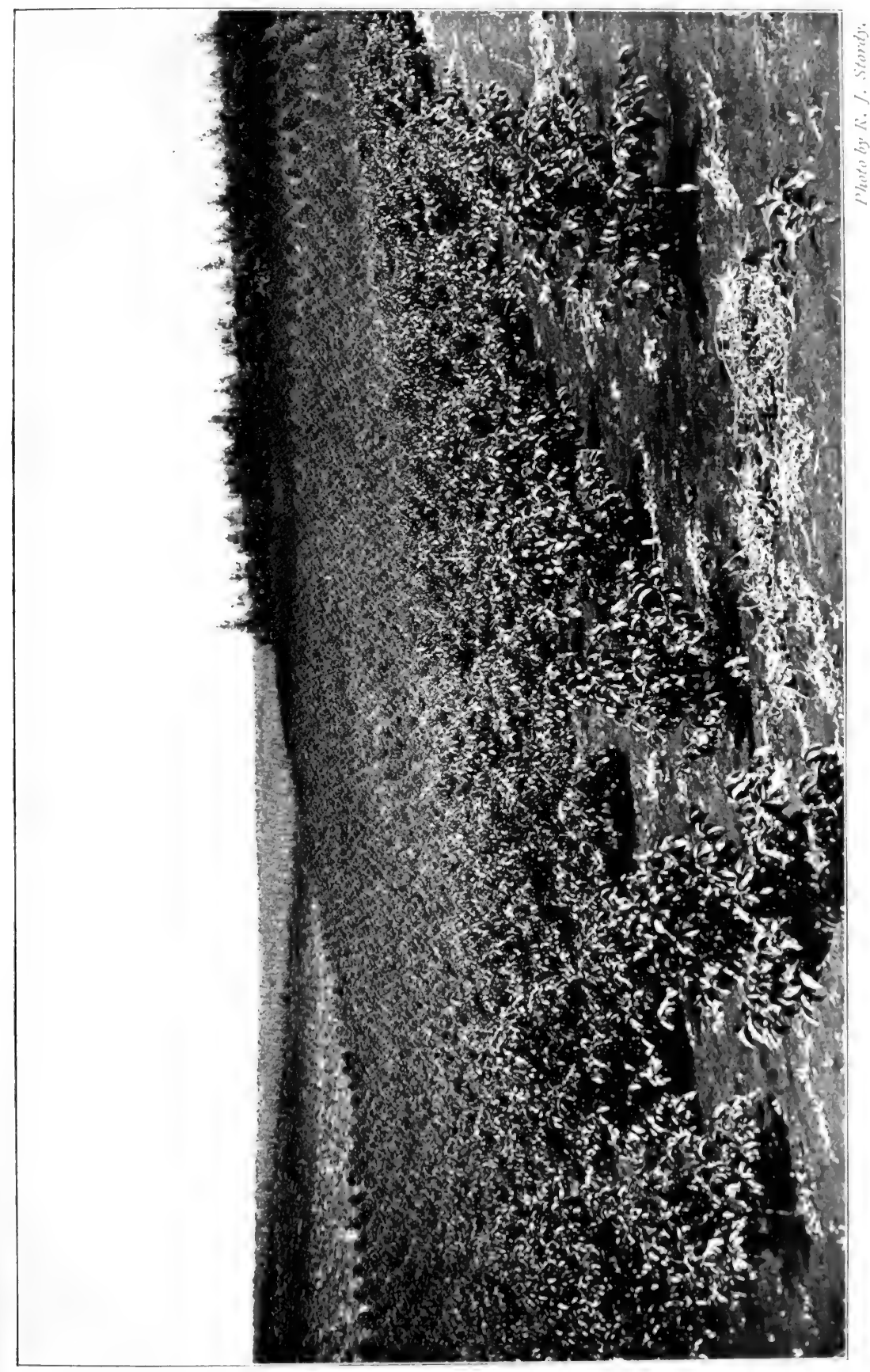



to $£ 55$ in 1909, it rose in I9I0-I I to as high as $£ 68$ per ton; while in the present year it has actually touched $£ 80$ to $£ 83$. There seems no risk whatever of over-production, and though the present price seems too good to last, and will probably not be maintained, there seems no reason to fear any considerable drop for very many years. There are very few parts of the Empire where coffee-growing prospects are as rosy as with us. Deep soil, sufficient rainfall, an abundance of little rivulets giving water both for washing the beans and also if necessary for irrigation, and an ample if somewhat capricious supply of labour are all ours. Uganda is perhaps the one place where prospects are even brighter. Rich as our soil is, hers is richer. Plentiful as is our labour, hers is equally so and, moreover, of a higher quality. The rainfall in Uganda, too, is both heavier and better distributed throughout the year; and this gives the result of a longer period both for picking and planting out and consequently the necessity for a more level supply of labour. On the other hand, East Africa has the advantage of a perfect climate as against an only fairly healthy one, an advantage which may be incalculable. Except for the initial expense in land, coffee-growing gives one of the best openings for a man of moderate means. The machinery required is cheap and a comparatively small area gives a good income. After three years' growth, and from that period onwards for at least six years, a profit of upwards of $£$ I 5 per acre can with decent management be confidently expected.

In selecting land, the very first essential to be considered is labour. The work of picking is not hard, and can for the most part be well performed by women and children; but, on the other hand, a great quantity

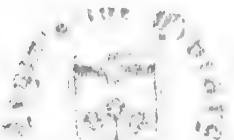


is required for a relatively short harvest and berries picked a week too soon or a week too late are seriously damaged, if not irretrievably ruined. One is here dealing with a valuable crop and one that can accordingly pay a substantial sum for transport. There is no necessity, therefore, to consider the proximity of the railway to anything like the same degree as with lower-priced crops. Indeed, if the competition for labour in the more easily accessible parts is considered, it will probably prove desirable to select one's area in a district where the native population is dense and not overtapped. For the soil, a deep rich loam of the red, or, better still, of the chocolate, variety is the best. A certain amount of water is essential, and it must be ascertained that the average rainfall is at least forty inches. For the best situations the intending planter must be prepared to pay. It will here, as in most crops, prove the cheapest investment to buy the best land even if $£ 4, £ 5$, or even $£ 6$ be paid per acrecheaper than paying $£_{2}$ for the second best or than taking the third best as a gift.

Having chosen his area of two, three or 500 acres, the planter will make and sow his seed-beds, and at the same time will prepare the first field for the reception of the young plants, and will take off it an initial crop of beans, mealies, wheat, etc. In the interim he will be well advised to prepare his mind by a thorough study of works relating to coffee generally and more especially to any hints that he can get as to local conditions. The seed beds can hardly be too carefully prepared. They must be of the best soil available and handy to water. Also they will require head-cover of banana-leaves or something similar. If the young plants are put out at the right season and at 
the right size they will not require any protection, but will go straight ahead. The ground must be kept thoroughly free from weeds. The young trees may attempt, but should not be allowed, to fruit before the third year. In this year the first crop will be taken and the income will commence. The fourth year, under favourable circumstances, $3 \mathrm{lb}$. per tree may be obtained, though this will prove rath er exceptional.

Both picking and pulping, especially the latter, are operations which require considerable care. The berries must be picked when they are "cherry-ripe," i.e., at that stage when the coffee gets bright red like a cherry and the skin is soft and easy to remove. The berry does not remain long at this stage, and must be picked then or not at all. The admixture of unripe or overripe berries will spoil the whole sample. The coffee must be pulped the same day that it is picked or at the very latest within 36 hours. A level and well cured sample is most desirable and more than pays for the extra care and attention. To this end it is essential that the pulper must be in perfect order; and a good supply of water is absolutely necessary.

At present there is no disease in the Protectorate, though the trees suffer periodically from the visits of the cutworm. The Agricultural Department are fully alive to the necessity of preserving our clean sheet with regard to disease, and in 1910 an Ordinance was issued absolutely prohibiting the importation of coffee beans and plants-only ground and roasted coffee being allowed to be introduced. 


\section{CHAPTER XIV}

PIGS, CATTLE, OSTRICHES

Pigs.-For the genuine settler, whether he be farming either on a small or large scale, the pig is almost a necessity; provided of course that he, the farmer, be within reasonable access of the railway. The great attractions of pigs to farmers in the Protectorate are afforded by three facts. He requires little labour. He eats food much of which is useless for any other purpose, and all of which is cheap. $\mathrm{He}$ is always readily marketable, and produces a profit at an early date. These qualities are, of course, the same essential ones which render the pig popular wherever he is bred; but they are especially commendable in a country where labour tends to be uncertain both in quantity and quality, where food stuffs either grow wild or are produced at a minimum of cost, and where a quick return of cash profits is continually required during the period of development. While some farmers, then, will keep swine as their principal products and will grow feeding stuffs to this end alone, many others will keep a sow or two more as a byproduct and to help defray the cost of living.

At the present time the Protectorate is equipped with an up-to-date bacon curing factory. To-day the 
local demand exceeds the supply, but an export trade is in the near future assured, and both the factory itself and also pig-breeders are preparing for this end by the production of pigs of a type which will cause British East Africa bacon to be hall-marked. When the industry first started and the factory was erected, the company, in order to encourage the enterprise, agreed to and did accept at a fixed price every pig that was brought to them. The result was bacon of an inferior or indifferent stamp. So long as the local market only was catered for, this was comparatively immaterial, but the moment that export was contemplated it was rightly decided either to refuse pigs of inferior stamp or to grade the price. Farmers have naturally been rather indignant at finding themselves with a quantity of unsaleable or unremunerative animals on their hands, and indeed the company would have been better advised to decide and advertise their policy at an earlier date. Still, the inconvenience is merely temporary, and there can be little doubt as to the correctness of the present policy.

The pigs known favourably in the country are the Large Black, the Berkshire, the Large White Yorkshire, the Tamworth, and the Middle White Yorkshire. Possibly their popularity comes in the order I have stated. Mr. E. J. Prosser, the wellknown expert, for some time resident in the Protectorate, states that the best cross for the country is formed by crossing a Berkshire sow with a Large White Yorkshire. Other practical farmers dissent, pointing out that Berkshires notoriously give small litters, and also that any white pig is more susceptible to the heat than his black brother. Large Blacks, either as sows or boars, are proving very popular. A 
good cross might be a Large Black crossed by a Berkshire, but there is no unanimity of opinion, and Large White Yorkshires have many adherents, more especially at the higher elevations where the temperature is cooler.

Pens and styes are easily and cheaply put up. They should therefore be large and roomy and opening into a paddock fenced in with sheep netting. In this paddock there should be plenty of overhead shelter in the way of trees or bushes, and also access to water.

The usual process adopted by the farmer is to buy two or more sows at an early age. Sows should not be bred from till ten months old. Economy of food and increased growth can be obtained by running them over stubbles or on swamps during the day. A few maize stalks or sweet potatoes thrown to them in the evening will be sufficient, and will expedite their return from the grazing grounds. Up to six months old, the young pigs can be run in the same way, though their evening meal should be rather more substantial-one pound per head, or more according to the natural feed obtainable at the time, of soaked mealies, barley, boiled potatoes, and separated milk, as available. Mixed food is always best, but naturally they must take what is to hand. If there is plenty of feed on the stubbles, a few sweet potatoes or green mealie tops may be sufficient. Pigs must have green food in some form.

After six months store pigs will be penned. For the seventh month they will get two good feeds daily, and for the eighth and onwards three at least, possibly four, care being taken to vary the diet. Barley is usually held to give the best and cheapest results, and is considered the most valuable pig feed. 
Good bred pigs should in theory weigh $160-200 \mathrm{lb}$. after eight months and be ready for the butcher, but in practice another month or even more will probably be found necessary.

Pigs in the Protectorate may be said to be in the main satisfactorily immune from disease. Naturally, it could not be supposed that they could be so entirely; and, unfortunately, in May, I907, the first outbreak of swine fever occurred. There seems little doubt that the disease was contracted from wart-hogs or bush pigs, more probably the latter. Since that time, although the disease has not been at all widespread, there have been several outbreaks. Scientific investigation has taken place, and two or three conclusions have been arrived at. It is, unfortunately, certain that at present the disease is more virulent than in England, only one animal out of 300 attacked in a series of outbreaks having been saved. It is also probable that immunity to ordinary swine fever does not imply immunity to the East African variety. This latter fact necessitates the establishment of a new serum for inoculation. In the meanwhile, as observed, outbreaks are by no means widespread, and there is no reason why, with proper precautions, any such should occur. The greatest care must obviously be taken to prevent the contagion being acquired from wild swine, which contagion is probably usually passed when herds are grazing round the edges of forest. Should an outbreak occur, there remain nothing but the usual and Spartan measures-All ailing animals slaughtered and their carcases burnt; also all litter and houses inhabited by the same. It is, indeed, probably better and cheaper in the long run to slaughter all animals which have been in contact with 
those affected. It must be borne in mind that not only is there no effective treatment for the disease, but that a post-mortem affords the only sure evidence of its existence. Finally, it may be said definitely that there is no portion of the Empire where pig-breeding has better prospects.

Cattle.-British East Africa possesses great stretches of country which, for cattle-grazing, can scarcely be surpassed. The grasses are for the most part sweet, good, and nutritious, and the double season ensures the continuance of good feed over the greater part of the year. Naturally as the grass gets thoroughly grazed down it becomes shorter, thicker, and sweeter, with plenty of clover springing up and becomes capable of carrying an astonishing head of stock. The Northern Masai in Likipia showed an instance of this. It has been estimated that in this district, on a grazing area of considerably less than a million acres, the Masai kept at least half a million sheep and 100,000 head of stock. Certainly the pasturage in Likipia is good, especially at the present time; but with an even amount of grazing it can be equalled, if not excelled, in many parts of the Protectorate. Cattle-raising is certain to play a great part in the history of the country. Every year the demand for bullocks and dairy cows increases, and the supply fails to keep pace with the demand. Owing to the enterprise of Lord Delamere, a refrigerating plant has been established in Mombasa, and when once the local demand is satisfied the home and foreign markets lie open.

Both the Government and private owners have given much attention to stock-breeding and grading, and there have been importations of pure-bred animals in good numbers. Among others, the following 


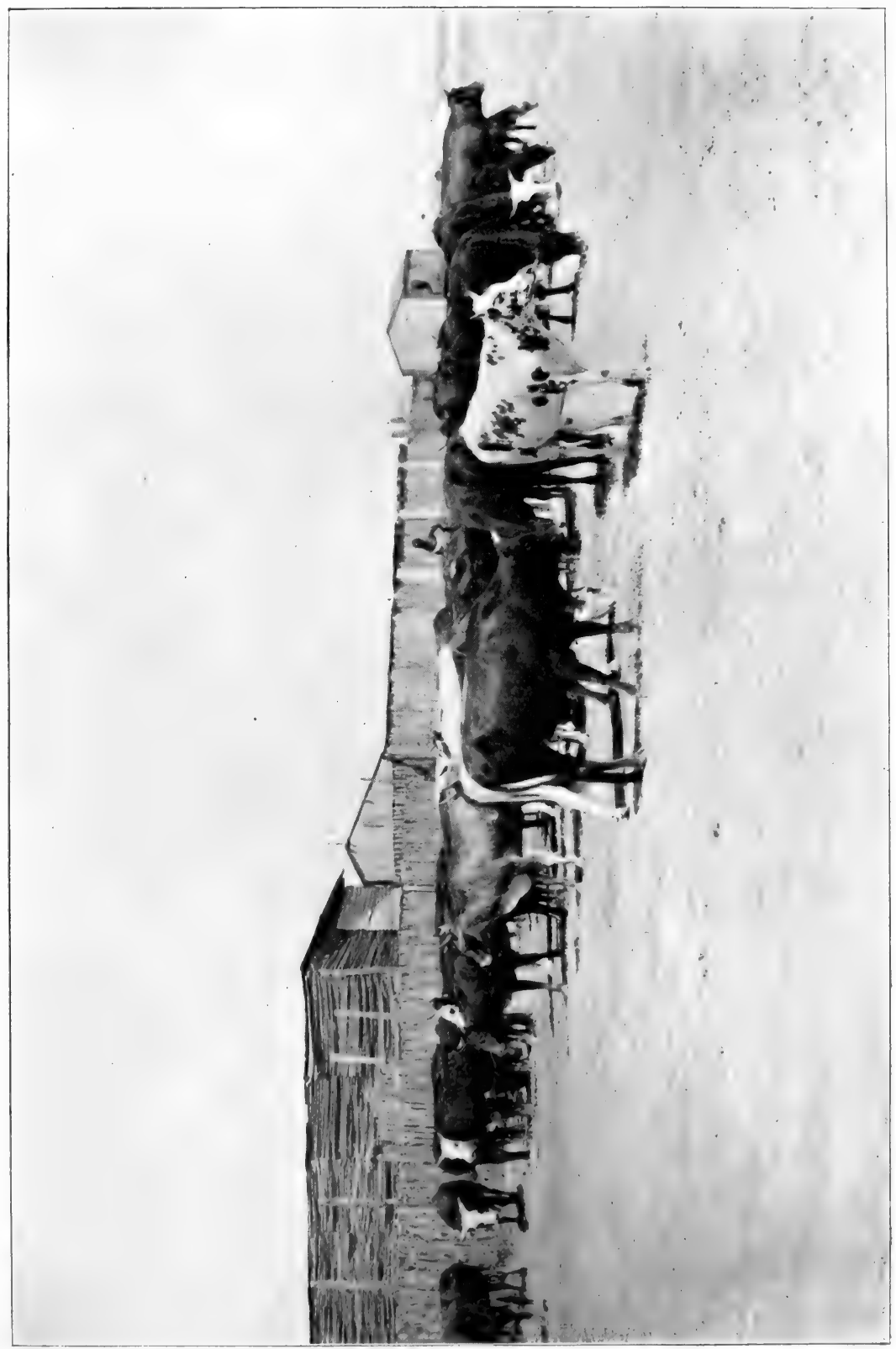

$=$ 

breeds have found favour: Shorthorns, Ayrshires, Herefords, Frieslands, Guernseys, South Devons, and Red Polls. All these breeds may be said to have done well, and their special characteristics have been introduced into their offspring. Where the grazing is less good and heat especially severe, the Ayrshires and Frieslands seem to have done best. The pure-bred Friesland calves have proved a great success, and up to date have developed as fast as, if not faster than, any others. South Africans have a special fancy for this breed, which has done so well in their own country, more especially where the grazing is of an inferior quality. The Hereford is essentially a beef-producer, and for this single quality has no superior. $\mathrm{He}$ is a hardy beast as regards heat, cold, and exposure, but up to date has proved susceptible to disease and not too vigorous in casting off ailments. Shorthorns have done extremely well, and the half-breds are making most excellent progress. The size, the high average excellence of shape, and the good milking qualities of the breed ensure their popularity here as elsewhere. The milking qualities of the Guernsey are notorious, and though he is too delicate an animal to provide a satisfactory pure herd, he forms a most desirable cross. Perhaps the grade of cattle that compares favourably with any is the three-quarter bred Guernsey-Shorthorn, which is hard to distinguish from the pure-bred. The Norfolk Red Poll cattle have always aimed at being dual purpose animals. Their beef has for many years fetched top price with the butcher, and for their size their milk compares in quantity as well as quality with any breed. Red Polls are also extremely healthy, almost entirely free from tuberculosis and stand both heat and flies well. I 
am naturally prejudiced in favour of the breed of my own country, but it seems to me that its record in similar countries proves it eminently suitable to this Protectorate, and I cannot help being delighted to see the young stock and half-breds looking so well. South Devons have many of the good qualities of the Red Poll, though their milking qualities are somewhat inferior. The breed has proved a very great success in South Africa, which should ensure our giving to it an extended trial.

For the settler who starts in on cattle raising, the best course is no doubt to grade up the native stock. To start a pure-bred herd will be for some years both expensive and extremely risky; such a policy, indeed, would be only likely to be justified were there an immediate prospect of obtaining high prices for the young bulls. Good native cows have gone up considerably in price during the last few years, partly owing to the increased demand and partly owing to several outbreaks of disease and subsequent quarantine regulations. A good native cow can hardly be bought under $£$ Io nowadays, and few tribes will part with their best. The Masai, indeed, hoard their stock in a way that is distinctly detrimental to the general prosperity, and, generally speaking, would rather starve than sell. An expedition sent up under the chief veterinary officer in the autumn of I9I I to examine the prospects of opening up cattle trade in South Abyssinia and the Abyssinian Boran found the cattle extremely plentiful and of fine quality; the natives, moreover, seemed anxious to trade. A purebred bull born in the Protectorate can be obtained at a local sale, or an animal can be obtained from England at a very moderate cost. Native cows breed freely, 
averaging over a cow a year, but pure-bred importations will probably only average four to five years. The bull should be kept in good condition; the extra cost will be many times repaid in the improvement of calves. Overhead protection in yards is desirable, though not absolutely essential; otherwise the greater the freedom and absence of pampering given to the animals the better for their general health.

Three diseases in particular have, up to the present, militated against the success of stock-breeders : rinderpest, East Coast fever and gastro-enteritis. Of these rinderpest is the most virulent. In countries where it has not previously existed the mortality on its introduction reaches 90 or 95 per cent. Where, however, the disease is endemic it sometimes falls as low as Io per cent. Rinderpest first visited British East Africa in 1892 , and for the next two or three years caused enormous damage, not only to cattle, but also to wild game. Rinderpest is an inoculable disease, which happy circumstance we owe to the discoveries of Koch in I897. In I9IO-I I rinderpest reappeared in the Protectorate, and was met at once by the introduction of serum, of which nearly 24,000 doses were issued. Generally speaking, such inoculations were successful, but in some cases large mortality ensued. There is little doubt that this latter result was due to the depreciation of the serum. It may be stated nowadays with some confidence that settlers need no longer look on this disease with excessive dread.

East Coast fever is a tick-born disease, being carried by two or more varieties of tick, the chief offender being the common brown variety. The difference of mortality is very great, but in the more serious 
outbreaks goes up to 80 per cent. Animals which have had the disease and recover are immune. Ticks which, having satiated themselves with blood, drop off are thereby purged of the disease, and the eggs of that insect cannot produce progeny which can themselves at first directly impart the same. Game form a suitable host to these ticks, since, though immune themselves to the disease, they purge every tick which gorges herself at their expense. Those people, therefore, who would find in an outbreak of East Coast fever an excuse for the destruction of the game, do so in ignorance of the real facts. Prevention lies in fencing, in dipping, or by obtaining a serum with which to inoculate. To attain this last end-obviously the best method of the three, if practicable-the disease had to be transmitted by inoculation from a sick to a healthy beast. After defying research for eight years, this stage was reached in I909. It is now reported that the requisite serum has been discovered. If this proves correct, the greatest, one might almost say the only, deterrent to stock raising in the Protectorate has disappeared.

Gastro-enteritis (Coccidiosis) was first definitely known in the Protectorate in 1908, but the symptoms and post-mortem appearances are so similar to those of rinderpest that there is little doubt that the two diseases have existed side by side for, at all events, some years. It differs from the latter-according to Mr. D. R. Brandt in the Agricultural Journal -in that: (I) Full-grown animals frequently recover ; (2) it is the young stock that die, and in them anæmia is nearly always present; (3) the rinderpest odour is absent ; (4) diarrhœa is not so severe; (5) the speed of the disease is slower. The best treatment is a purgative given early in the attack. Prevention is 
best obtained, according to Mr. E. R. Montgomerie, veterinary pathologist to the Protectorate, by segregating all new purchases for at least six weeks before allowing them the run of the usual grazing grounds.

Ostriches.-As regards ostriches the Protectorate is yet in its infancy, but there is every reason to hope that it is the infancy of a very lusty child. The main ground for this optimism lies in the fact that the wild birds, which form the foundation on which the industry is being built, are of altogether superior stamp to those which were the original stock of South Africa. Professor T. E. Duerdon, one of the most eminent authorities on ostrich breeding, in the course of a series of most interesting articles published in South Africa, makes some noteworthy admissions. He states therein that all the many years of selection and breeding, and the expenditure of enormous sums of money, have not tended to raise the individual desirable qualities of individual feathers. Furthermore, that it is impossible to do so. The professor states with authority that the original wild stock of South Africa possessed occasional feathers of equal length to any now grown, occasional feathers of equal shape, others of equal density, hardness, or gloss. All that the science of breeding has been able to effect has been to combine the various highest qualities into one feather, and gradually to ensure the fixity of such feathers and complete crops of the highest class. Thus a single one of the finest plumes of the modern bird could not be matched by a wild bird in the combined essentials of size, shape, density, hardness, and gloss ; still less could he be matched with regard to the complete crop. In one point it is indeed admitted that the domesticated ostrich has actually deteriorated, and that is in the 
hardness and firmness of the flue, these qualities being desirable from the point of view of the trade. Soft living and luxury have induced softness and woolliness of flue, and to restore the original quality some of the best breeders in South Africa are desiring a re-introduction of wild blood and are turning their eyes towards the wild stock of British East Africa.

Now these statements, made with so great authority and in so convincing a manner, must be a source of the utmost gratification to all ostrich breeders in the Protectorate. It is universally admitted by those who have had an opportunity of judging that our wild birds are superior both in size and feather to those of South Africa. If, therefore, we choose or are forced to start at the bottom and evolve our breed of ostriches by selection from the local stock solely, we shall in all probability, in the course of ten, fifteen, or twenty years, produce a sample which the south cannot match. One thing seems fairly obvious. South African breeders have already approached us with a view to obtaining cock birds. Unless they are prepared to treat us in the fairest and most reciprocal manner by exchanging breeding birds of the highest quality that they have evolved, we should be extremely chary of parting with our tangible asset.

In the meanwhile, progress is steady, and it need not be thought, because the prices obtained by our feathers are at present comparatively small, that even these prices are such as will not pay the settler who, starting from the beginning, determines to make ostrich-breeding his staple industry. On the contrary, there is no reason whatever why a settler starting with a capital of $£ 800$ or even lower should not find himself at the end of five years with an income as large as 


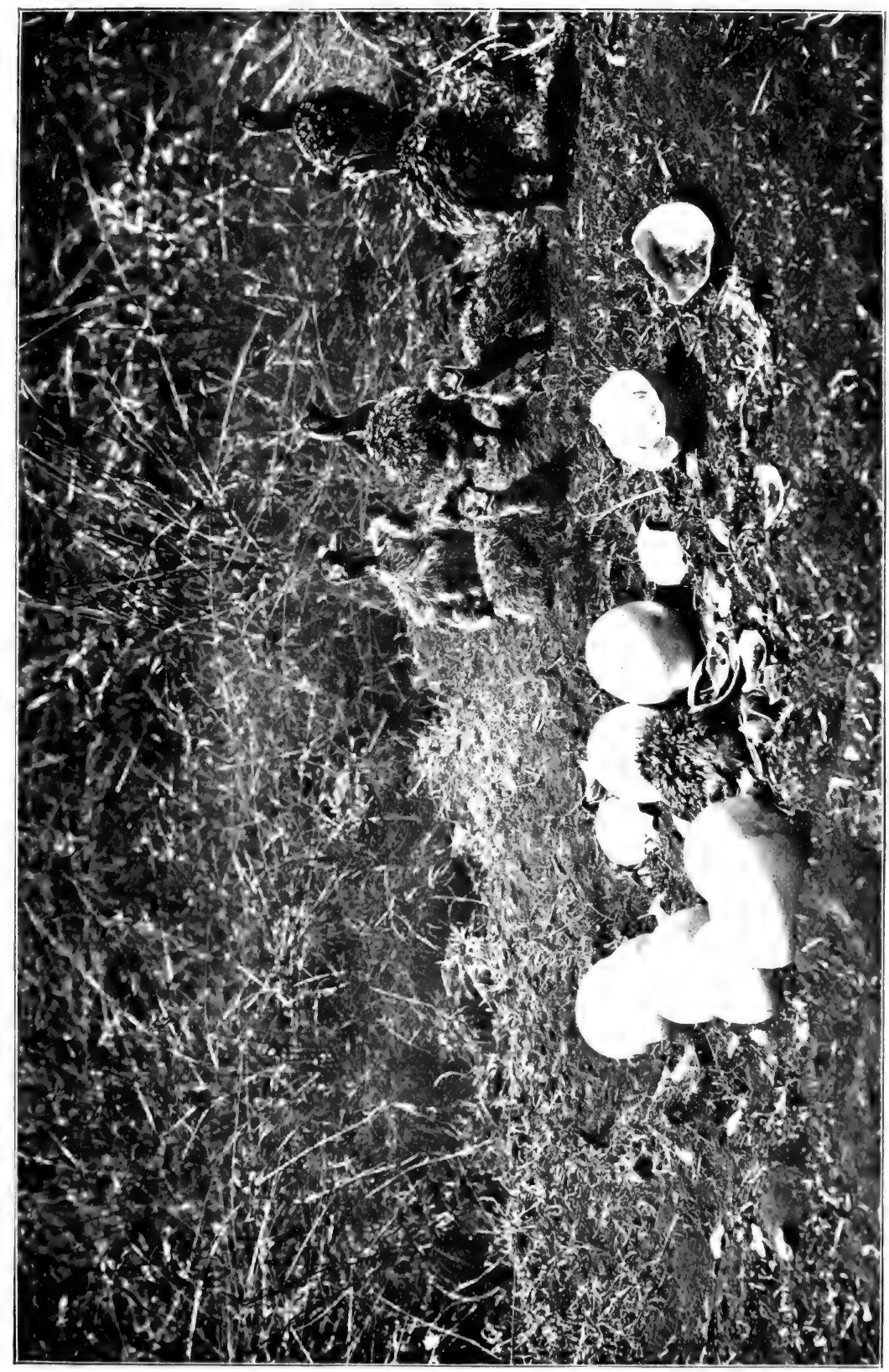



his present capital, and one, moreover, which will show every sign of further growth.

The area to be selected should be chosen for the natural feed thereon; for the number of wild birds who frequent, or have in the past frequented it, thereby furnishing evidence of its suitability; for the lack of lions, leopards, cheetahs, or other vermin, and for the possibility of irrigation. The last item is on a small scale almost essential, since a certain quantity of lucerne throughout the year is necessary to keep the birds in a thoroughly healthy condition. The flock may be started by buying breeding birds, young chicks or eggs, or by the capture of young chicks and the discovery of wild nests. On the score of expense, the latter method is to be recommended. Up to the age of a fortnight or rather more, wild chicks can be ridden down and a most entertaining pastime it is ; but the better way is to watch for the nest with glasses from a likely hill-top. When the cock and hen change, which they do generally about ten in the forenoon and four in the afternoon, is the most likely time to locate the nest. In approaching, care should be taken not to go too close, since a hyæna is fully capable of following up the human trail to obtain his favourite meal, with the result that the next morning inspection will reveal a scene of devastation. It is sometimes said than an old hoop or a piece of iron will keep off the vermin in the same way that a partridge's nest may be preserved from the attacks of the fox.

Among the best portions of the Protectorate from which eggs or young birds may be obtained are the Southern Game Reserve and adjoining areas and the Loieta, Lemmik, Sotik, and Yatta plains. Eggs are, 
nowadays, nearly always hatched out in incubators, for, as an authority has said, "the birds are too valuable to be wasting their time."

The incubation of ostrich eggs is a very expert task. A level temperature of $98^{\circ}$ or $99^{\circ}$ is essential, and any great variation is generally fatal ; however, occasionally the eggs will hatch under the most unlikely conditions.

The rearing, keeping, feeding, and selection of birds is an extremely fine art, and expert knowledge is eminently desirable. British East Africa has certainly not suffered from a plethora of experts in this line, and the comparatively slow progress made must in the main be attributed to the existing ignorance. When one considers the abstruseness of the questions connected with the effect of feeding on feathers, of plucking before the quill is ripe, of the effects of cold and rain, of the selection of birds and of the desirability of weeding out inferior specimens, one cannot help being astonished at the results that have been obtained with the limited knowledge at our disposal. It must not be thought that we are altogether without our experts, but rather that, although some breeders have knowledge, the majority have entered on the task light-heartedly and with a lack of knowledge which experience, however dearly bought, can never wholly rectify. Ostrich breeding seems one of those industries with regard to which the Agricultural Department might with advantage issue a short, concise and authoritative pamphlet.

Ostriches are, generally speaking, healthy, though liable to the attacks of a worm in the intestines. Though this parasite occasionally causes death, far more damage is suffered from extraneous marauders, of whom lions and leopards come first, with native thieves a good second. The young ostrich is to the lion a 
delicacy, even as is the oyster to the gourmet. Curiously enough, so shrewd an observer as Mr. Stigand comments in his book, "To Abyssinia through an Unknown Land," on the peculiarity of finding an ostrich recently killed by a lion, since it is extremely rarely that they will touch them. Had he been an ostrich breeder he would have found it far from unusual. The length to which lions and leopards will go to obtain a good tuck in among young ostriches is extraordinary. Last year, two breeders completed an ostrich enclosure which they felt was so secure that they might rest happy in their beds. The boma was perhaps 40 yards square, and consisted of huge posts some $10 \mathrm{ft}$. high and was bound together by strands of barbed wire within and without at intervals of three or four inches. In all there were more than seven miles of barbed wire around it. Outside, again, was a fence of thorns, in itself almost impenetrable. Nevertheless, the settlers' confidence was misplaced. One morning they were roused with the unwelcome tidings that five lions had visited the enclosure, had slain fifty odd out of seventy ostriches contained therein, and had then decamped-all save one, who was too swollen to retreat through the gap by which he entered. The captive dispatched, an inspection was made, and the fury with which the lions had made their attack on the boma was evidenced by the blood and fur strewn about. The gap had been formed by literally tearing with teeth and claws the wire from its supports and eventually forcing open a narrow hole. Nor was this all. Next morning the boy who brought the early tea remarked, "Tea, sir, and another big lion in the boma!" Running out in pyjamas, another fine male was found unable to locate the means of egress and was shot, which experi- 
ence was repeated on two subsequent days! The skins of the dead beasts were found torn and scratched in every direction by the barbs. Hardly less pertinacious, and more difficult to bring to justice, are the native thieves. The fact that the birds must be enclosed at night renders the theft of feathers easy and in certain districts a great deal of loss has been suffered. The authorities have undoubtedly done their best to stamp out the evil, but their efforts have not up to date been crowned with any conspicuous success. Some of the heaviest sufferers are undoubtedly and naturally getting exasperated, and there is always the fear least they may take the law into their own hands. We may anticipate that there will be legislation of a more drastic nature in the near future.

Smarting from the ill effects of one or other species of marauder, breeders from time to time take a pessimistic view of their prospects. Thus one of the foremost ostrich farmers in the Protectorate writes that, as being the result of personal experience, the following pithy article on the ostrich may be of value :-

"The ostrich is, as is well known, a beautiful bird of enormous value on account of its priceless feathers, which are universally worn by the fairest of the fairincluding the natives of East Africa-more especially as a head-dress. Unlike other birds, he has six toes, and although two useful legs, generally prefers to roost on one. It is a bird of abnormal intelligence, as may be grasped from its reputation of employing the very cute ruse, when attacked by an enemy, of burying its head in the sand to avoid recognition. As regards diet it is equally remarkable, and in this country it seems to thrive best on hard, sharp, and as a rule shining objects, such as empty cartridge cases (more especially of the 450 brand), staples, long nails, 
blocks of white quartz about the size of a cricket ball, but the more angular the better, broken china plates, glass bottles, lids of jam tins, door hinges, etc. It may be as well to dispel any illusion that may be entertained by the ignorant in England that ostriches are bred and kept in this country on account of the marketable value of their feathers. This is far from being the case. They are farmed and fattened in large quantities solely and entirely as food for lions. Indeed were it not for the truly altruistic spirit of the egg-catching company of ostrich farmers in the Protectorate, who are here to spend money and not to make it, it would, I think, be quite safe to say that this happily numerous species of giant cat would have long ere this become extinct."

This bitter and sarcastic lament was, I imagine, induced partly by recent losses and partly by a deranged liver. 


\section{CHAPTER XV}

\section{SHEEP}

Sheep.- The earliest experiments in sheep-farming in British East Africa clearly demonstrated one important fact-that certain qualifications and local knowledge must be acquired by the farmer before a successful result could be obtained. Even to-day the characteristics and requirements of a large proportion of the Protectorate as a sheep-raising country are very little known; this being so in view of the fact that fashion to a great extent has allocated the various districts to various industries, and that newcomers have hitherto been inclined to follow the footsteps of the earlier settlers who have established positions which indicate success. However, in those parts, and more especially in the Rift valley, where the sheep industry has attained a considerable scale, history has shown that the amateur, as well as the professional, shepherd who has had some months' experience on an established farm can safely count on a satisfactory return from his flock; provided always that his constant attention is devoted to its supervision. Whatever may be a man's previous experience with sheep, and however well such experience may serve him later when questions of type and selection arise, a period or 


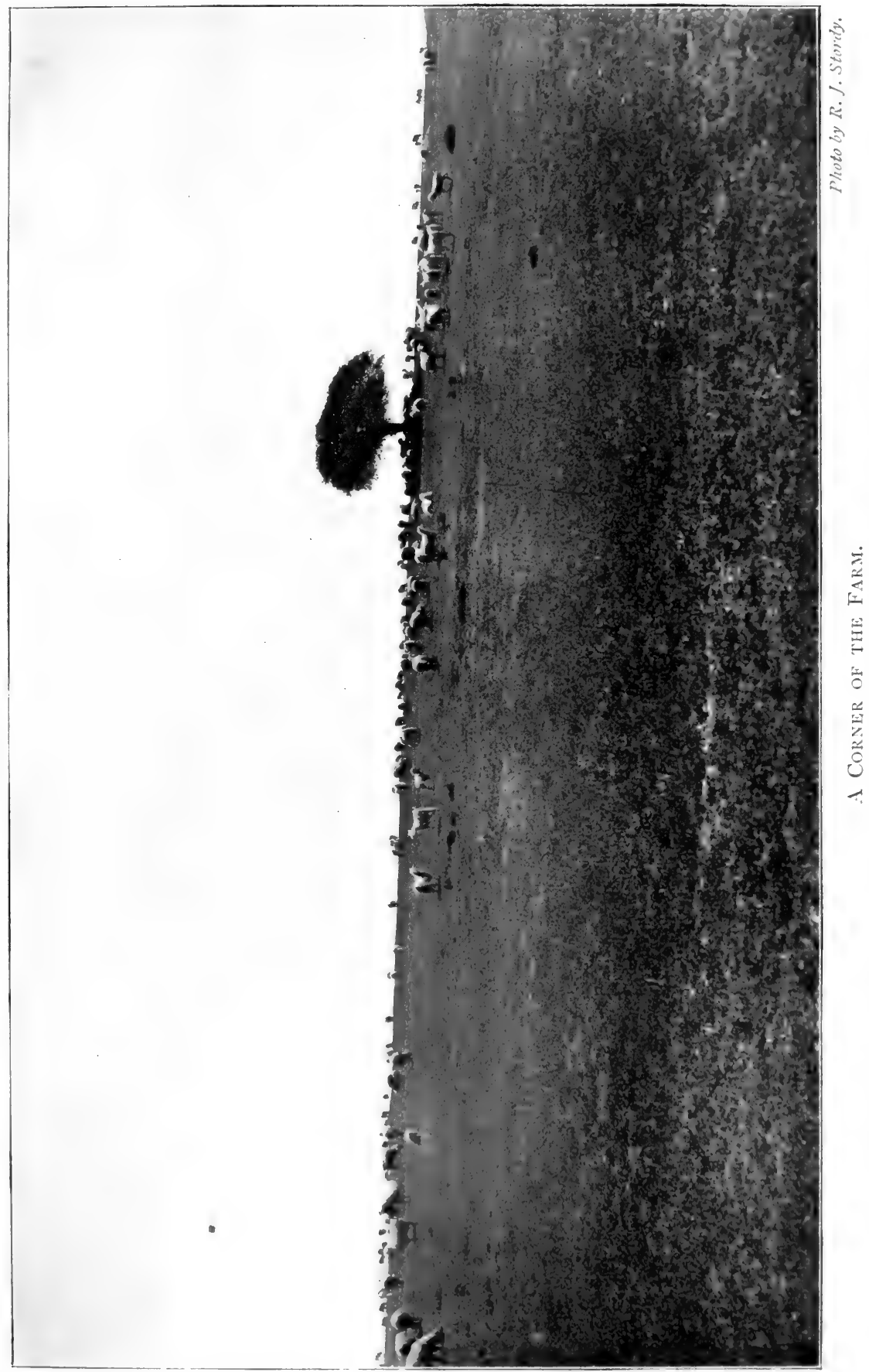



apprenticeship must be served by all. This applies to every man, Englishman, Australian, or New Zealander, who wishes to avoid an inevitable loss and delay. The South African farmer alone will find conditions of disease and herding more or less similar to his own; and even he has much to learn.

The settler who arrives with the intention of sheepfarming has to-day a far larger field from which to select a site for his operations than the man to whom immediate means of communication and a plentiful supply of labour are essential. And here it may be emphasised that already people are beginning to realise that, large though our supply of native labour is, it is yet totally inadequate to put under the more valuable crops, such as coffee, sisal, and wattle, the total area which might otherwise be developed in this way. If, as appears likely, free grants on a sufficient scale may be no longer obtainable from Government, he, the settler, may yet acquire tracts of country at nominal prices which are well suited to his purpose. Moreover, such areas will tend consistently to increase in value as communications improve and closer settlement becomes feasible. The Uasin Guishu Hinterland and West Kenia contain areas which at the present prices of six to ten shillings an acre offer exceptional facilities for the purpose, and when the long-delayed and extremely mismanaged movement of the Masai is an accomplished fact the Likipia plateau will offer areas at least as good as any now available.

The farmer who has secured his land has next to decide between two courses : whether to acquire a mob of native ewes and from them to grade up to the pure sheep, or to import a pure-bred flock and establish himself immediately in the position which by the other method 
he will not attain for many years. This choice will be influenced by two prime considerations, the length of his purse and the size of his holding. If a man has a limited purse and a large run, anything over 30,000 acres, he almost must of necessity stock his land with native ewes which will cost him from $5^{s}$. to $7 s$. $6 d$. per head rather than import a pure bred flock at an average price of $£^{2}$. On the other hand, if he has a run of but 5,000 acres, and also a well-filled pocket, he will get the best and quickest results of full development by importation. With pure bred merinos there is no question of deterioration ; on the contrary, they more than maintain their vigour, and the wool improves both in weight and quality. It has already fetched II $\frac{1}{2} d$. a pound. $U_{p}$ to the present date almost without exception the pockets of our sheepfarmers have not been lined in full proportion to their acreage; they have had, in fact, more mud than money. Without attempting to offer a table of comparative results from these two methods, which would be affected by the price of wool in the home market, by the local price for ram lambs and still more by the capacity and value of the farm, the fact remains that in almost every case farmers have been content to use the native ewe as their basis, relying on their wethers to pay expenses, and anticipating in the ultimate wool clip from the graded ewe flock the profit which previous results have indicated. Their reasons have been that the small capital available for stock was more safely invested over a large number of animals at the lower price acclimatised to the country than in imported stock. Grazing cost practically nothing and herd boys could be trusted more safely with the lower priced animals. In any case there 
could have been no appreciable difference in profit, and for the man with cheap land and limited capital the native ewe may still prove the best friend.

Now supposing that our settler has decided on grading up the native sheep, the next question to be settled is the type to be acquired. At present the Masai ewe has proved herself the most adaptable; she has a strong constitution, and though flat-sided is of considerable size. Three parts of the trading stock in circulation in the Protectorate came from the Masai and at prices of from six to eight shillings breeders will not go far wrong with them. A type the true value of which is hardly yet appreciated is the Samburu, a breed of Persian sheep, on the small side, but well shaped, with fine bone, and excellent mothers. The cross-bred lambs from this type show a better staple and less kemp in the wool than any others. Unfortunately, they are drawn from a low, dry country, and the percentage lost in acclimatisation is considerable, though this is discounted to a great extent by the lower cost, approximately one-third below that of Masai ewes. Karamojo and Turkhana sheep, which also show Persian breeding, suffer from the same disadvantages and are in addition materially smaller, while sheep from the Suk valley, though larger, appear almost impossible to acclimatise.

In most cases the settler will purchase his breeding stock at auction or from trading Somalis, but he may economise to some extent by taking trading stock and proceeding into the native Reserve himself, in which case he will do well to take also with him some trustworthy Somali or Swahili, if such there be, as the necessary bartering is a slow business and apt to tax the patience of the European. 
After the ewes have arrived on a farm, some time must elapse before they are ready to receive the tups, for the native owner has rams running continuously with his ewes, and it is advisable for all the resulting lambs to be dropped before a regular lambing season is instituted. This season usually takes place in the months of April and May, and of October, November, and December, when the grazing should be in the best condition for milking ewes.

It will be observed that the farmer can make use of two seasons within the one year; and while dealing with his native and initial crosses he will probably decide to do so. There has been no sign as yet that constitution suffers in any way, though there certainly is a presumption that in pure breds or advanced grades the quality of wool will tend to deteriorate. In any case, the larger increase is too attractive to miss, and the practice even of the Government experimental farms is to take two crops of lambs from grade ewes. In order to maintain the two seasons, they must be very carefully regulated. Ewes with lambs at foot will take the tup at a month to six weeks after lambs have been dropped. In order to carry out the system of two seasons, such season cannot extend over a longer period than six or seven weeks; the tup must accordingly be working among the ewes a clear fortnight at least before the end of the season. These regulated seasons must never be altered, and therefore the temptation to continue the tupping season another week at a time when the ewes are taking freely and well must be firmly resisted. Newly-imported rams are, more especially during their first season, uncertain stock-getters. It is therefore a desirable practice to run reliable rams with the ewes during the last week of 
the tupping season. Lambs should be docked at the age of three weeks and castrated at six.

For some years the most desirable type of ram to introduce among the native ewe flock was a matter of considerable controversy. Mr. J. K. Hill, formerly head of the Government stock farm and one of the soundest and best informed farmers in the country and others argued that a ram from one of the larger grown breeds, such as Suffolk or Lincoln, would be liable to get as the first cross a larger framed progeny than could be obtained by direct merino cross. However, in addition to comparative failure in its main object, such grades have the disadvantage of being considerably more liable to disease than the direct merino, and of a less hardy constitution in every way. In introducing a breed a sound maxim is to introduce it into conditions more favourable than those to which it has been accustomed. This maxim accounts, no doubt, for the greater success of merinos than of the larger breeds. It must not be thought however, that mutton sheep cannot be bred successfully, for the crosses, and more especially grades of Shropshire, are exceptionally promising both as regards shape and early maturing qualities; but indications point to wool as the most necessary and more lucrative side.

A year or two ago the second cross merino was held to have done well if the flock averaged $5 \mathrm{lb}$. to the clip ; later results, however, have far exceeded this, and 6 to $8 \mathrm{lb}$. is not unusual. The wool itself is comparatively free from kemp, and should be worth at least $8 d$. in the London market. Third crosses give from 7 to Io lb. of proportionately improved quality, which wool has already realised $\mathrm{I} d$. per $\mathrm{lb}$., while pure merino 
country breds average from 9 to $2 \mathrm{lb}$. and has already fetched II $\frac{1}{2} d$. Too much care in preparing and sorting wool can hardly be taken. In this direction South Africa furnished an example and a warning to sheep farmers. Writing in the Cape Journal for August, 1909, Mr. Price, one of the largest exporters of wool in South Africa, complains that South African wool has so bad a name that were the very best Australian wool exported from South Africa it would not fetch within $3 d$. of its true market value. This bad name he attributes almost entirely to the fact that the early wool-growers of the Colony paid such scant attention to the get-up of the clip.

During his pupilage or educationary period the intending sheep farmer will naturally spare no pains to make himself familiar with as many forms of disease as possible. Besides scab and footrot, the latter usually the result of yarding at night in wet weather, the only disease which is likely seriously to trouble him is one known to the Masai as Ngaaruti. The mortality, however, even from this has not up to date proved severe; further, the results from the pathological laboratory now show that it is inoculable, and that there is every hope that by the end of the year an effective antidote will be available. Worms are constantly in evidence, especially among the young stock, but regular dosing is an insurance. Mild outbreaks of Variola and Blue Tongue have been attended by a negligible mortality. A very much heavier loss than from each and every form of disease may be, unfortunately, anticipated from the depredations of vermin, both of the four-legged and two-legged varieties.

A most satisfactory portent to flock masters lies in 


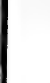




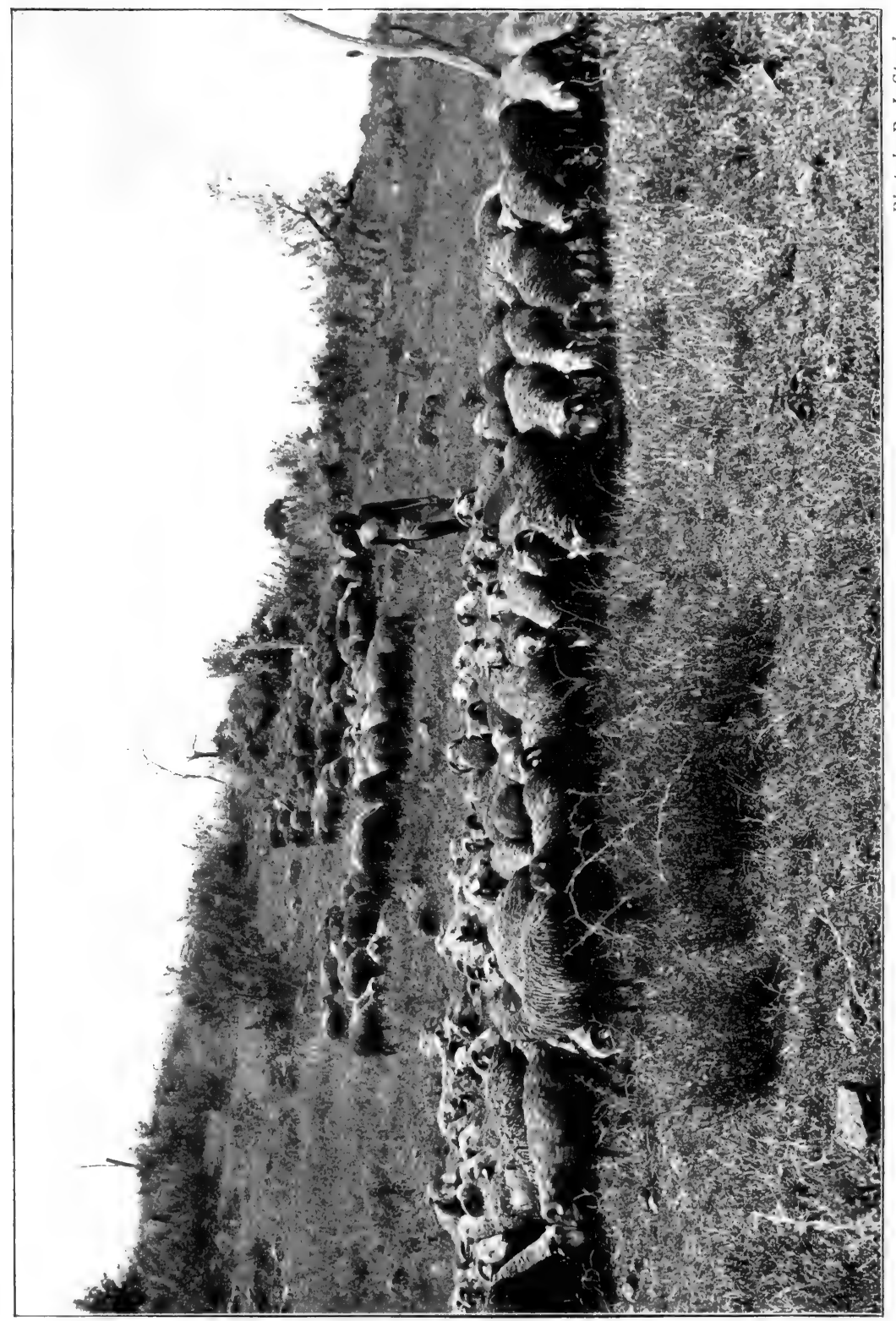

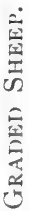


the fact that it has been shown in Australia that as the merino travels inland towards the Equator so does the quality of his wool improve instead of degenerating according to anticipation.

Private owners, as well as the Government, are now importing high-quality rams freely, and in a very short time the intending farmer will be able to purchase all the best blood of Bonooke or of Wanganella at a very moderate price.

When the cost of maintaining a flock in the Protectorate is considered, it will be seen that prospects could hardly be brighter. We have the best of grazing, carrying often two or even more sheep to the acre; and this, moreover, without anything in the way of improvements such as paddocks or increased water supply. We have native herds who, in spite of a penchant for mutton, will shepherd, shear, or dose under reasonable supervision for the princely sum of ten shillings a month. We require the minimum of capital expenditure in the way of sheds and yards. With the exception of a dip, a drafting yard, and a few cheap sheds for valuable rams, nothing of a permanent nature is required for the use of the sheep.

With these considerations, viz., land, labour, and equipment, on a minimum basis, it can well be understood that the annual cost per head may be reduced below one rupee, which sum the pioneers of the industry considered the reasonable limit. On the other hand, the corresponding revenue can only be determined by the capacity of the farm and the enterprise of its owner.

When one considers what they have done in Australia, where there are now more than 50 million 
of sheep, but where it took fourteen years to increase the head from 29 in 1778 to 105 in 1792 , it must be held that our progress has been phenomenal ; and it cannot be denied that in sheep farming at all events prospects are of the brightest. 


\section{CHAPTER XVI}

FORESTS

IN her forests, and more especially in her Highland forests, British East Africa possesses an asset of the very utmost value. An authority, and perhaps the authority best calculated to judge, has said that the timber of the Protectorate is worth twice as much as the whole of the rest of the country put together. Of this asset no reasonable man can say that we have as yet made the best use. There are, as I shall show, at the present day at least two million acres of valuable timber in the Highlands. Of that amount, during the whole period of our administration, less than 200,000 acres have come into private ownership for purposes of development, or have been leased for the same purpose; and of this 200,000 acres about 20,000 escaped the talons of the Government by pure inadvertence on their part, while no stone has been left unturned and no process of law or bluff omitted to re-obtain possession of another and much larger portion. During this same period the entire destruction of at least 200,000 acres of good forest at the hands of natives has occurred in the Government area. The reason of this ghastly hoarding, not to say waste, of our most valuable possession lies in the fear lest private individuals or companies, or, worse still, a 
speculator should make a profit, and also, no doubt, by the feeling that every year the forests get an enhanced value. One hears a lot about the iniquity of the holding up of such possessions on the part of private individuals, and a tax on unearned increment has very rightly been invented in England to cope with the abuse. There must surely come a period when even on the part of Government this same clinging to possessions which cry for development ceases to be commendable.

The main extra-tropical forests in the Highlands consist of :-

The Mau Forests

The Aberdare Forests

The Kenia Forest

Forests near Nairobi

Mount Elgon Forests

Forests on the

$\begin{array}{rr}= & 768,379 \text { acres. } \\ = & 477,440, \\ = & 400,000, \\ = & 6 \mathrm{I}, 440, \\ = & 32,000,\end{array}$

32,000 ",

Unexplored and small Forests 200 or 300 square miles.

It is the three greater forests which form the most valuable portion of our timber; this is so not only because of their superior size, but because, being on a higher zone, they contain, as a whole, a more valuable class of tree. There is one exception to this statement; the Ibean Sandal (M'hugu) which grows freely in the forest round Nairobi, being one of the most valuable trees in the Protectorate. Not only for sandal work, but for sleepers, fencing posts, and firewood, it is not to be surpassed. It does not grow freely on the higher zone. The forests of the upper zone contain, not only all the largest trees, but practically all the conifers. The four chief timbers are two forms of Yellow-wood (Podocarpus gracilior and Podocarpus 


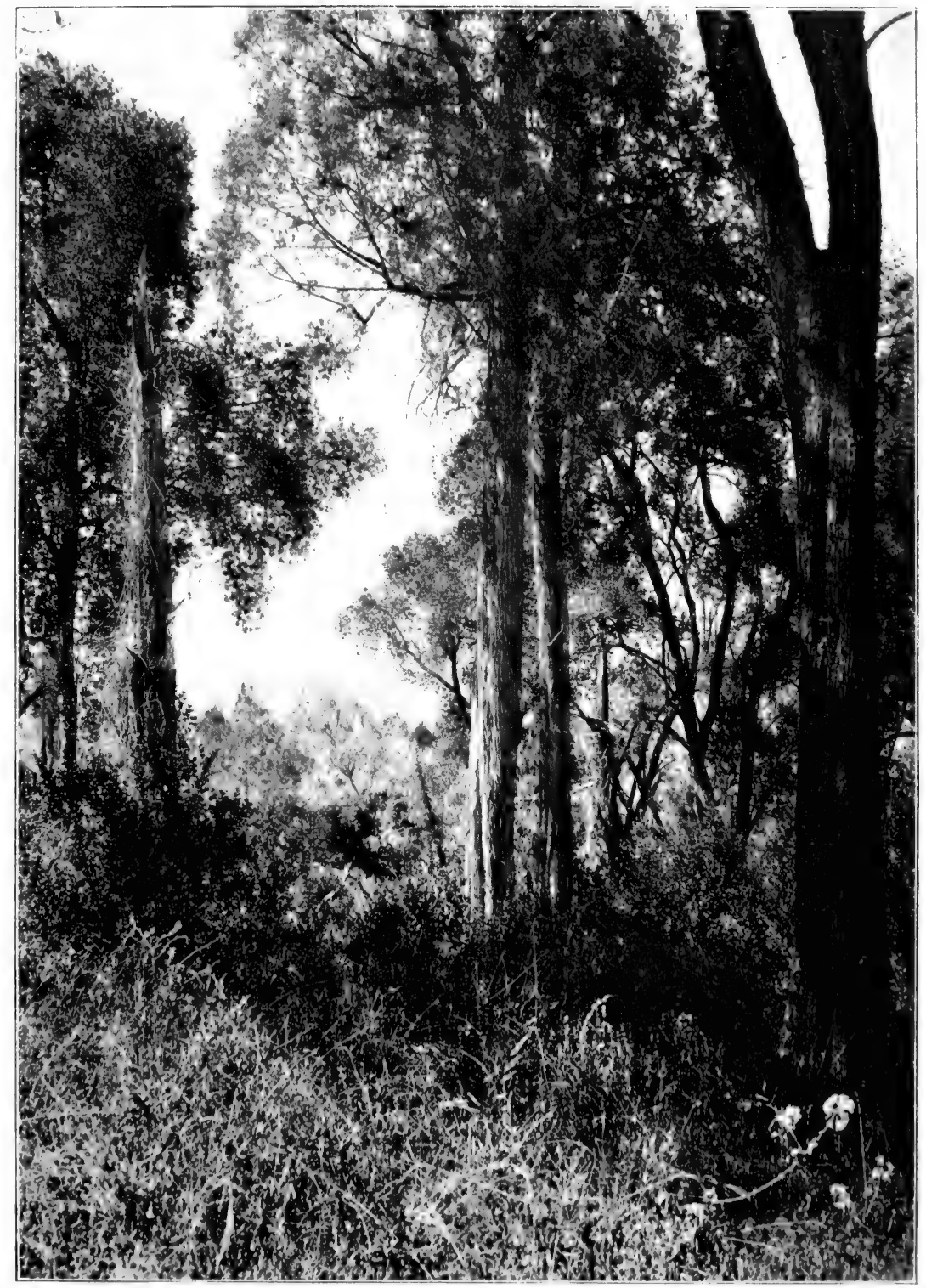

Ploto by R. J. Stordy. 

Thunbergii), Cedar (Juniperus procera), and Ibean Camphor (Ocotea usambarensis). Of the two latter, cedar is the commonest in the drier portions of the forest, while camphor is confined to those that are more damp. Next to these four, comes olive (Olea chrysophylla). Of the three great forests, the Aberdare forest is considerably the least valuable, and has also suffered by far the most from grass fires and native destruction. Mr. D. E. Hutchins, late forest officer, computes in his most excellent blue book that in this forest alone the Kikuyu have within recent years destroyed no fewer than 350 square miles of valuable timber. If a considerable portion of the sums expended in preventing a comparatively few acres from being utilised by settlers had been used to conserve our timber from destruction by natives, we should have been better off to the extent of millions of pounds.

The total Aberdare forests consist of :-

Eastern Aberdare $\left\{\begin{array}{l}\text { Southern forest }=96,000 \text { acres } \\ \text { Bamboo forestwith } \\ \text { interspersed Yel- } \\ \text { low-wood }=124,800 \text { acres } \\ \text { Northern forest }=228,480 \text { acres } \\ =28,160 \text { acres }\end{array}\right.$

Of this the Bamboo forest has no commercial value, and of the rest the finest portion is what is known as the Thomson forest, which represents an area of about IOO square miles of good timber. A considerable proportion of the forest on Western Kenia has been granted to the East African Syndicate.

The Mau Forests, though in no solid continuous block, like the Kenia forest, comprise the largest area of timber in the Protectorate. Taken as a whole, it is 
not so good as the Kenia forest and nothing like so easily worked, yet much of it is very valuable. Portions of this forest have been leased to Messrs. Lingham and Grogan, and some 30,000 acres have been alienated partly to Lord Delamere and partly to $\mathrm{Mr}$. Atkinson. The area which belongs to $\mathrm{Mr}$. Atkinson is perhaps the only area of the two million acres of forest land in the Protectorate which has been systematically and properly worked. It is now understood to have been sold. The large area leased to Messrs. Grogan and Lingham contains perhaps in one portion the heaviest stock of timber per acre in any part of the country, though it is run hard by part of the Sotik forest, where the cedar is close, straight, and often sound, and also by portions of the Camphor forest on Kenia. Messrs. Lingham and Grant, men of considerable experience, estimated that on the Elgeyo escarpment there were a great many acres which averaged more than 15,000 cubic feet of coniferous timber.

The total area is made up as follows:-

Elgeyo forest, stretching towards

Nandi-Approximate area of good forest $=60,000$ acres

Sotik to Naivasha, the largest

of the forests

Elgeyo escarpment forest

$=240,000$,

$=89,600$,

Londiani, Mau, from Mt. Blackett $=20,480$ ",

Ravine, Khamasia (very poor

forest)

$=80,420$,

Scattered forest in Nandi country $=160,000 "$

Sotik, Lumbwa forests

Mt. Londiani forests

$$
\begin{aligned}
& =32,000 " \\
& =85,879 "
\end{aligned}
$$


The Kenia forest is, without doubt, the most valuable forest in the Protectorate. This is so, not only on account of the average density and excellence of the trees, but also on account of the peculiar conditions which will render the export of the timber both easy and profitable. The bulk of the trees are of the usual four varieties, the two yellow-woods, cedar and camphor, but the hard woods are here present in a greater proportion to the soft. A general average of areas measured showed 3,625 cubic feet to the acre, though of course this is in many parts far exceeded. The finest timbered parts of the forest are the southeast portion of the crescent, where there is a belt of huge camphor trees growing at a height of between 6,000 and 7,500 feet. The average cubic contents per acre of this area are certainly in excess of 7,000 , while in some patches they probably reach 9,000-and also the almost pure cedar portion to the north-west corner.

It is not, however, only the amount and value of the timber which must be considered in appreciating this forest, but also the comparative ease with which this timber can be removed. In the first place, unlike the forests on the Mau, and indeed in most other parts of the continent, this forest is not to any great extent intersected by ravines or gullies. Mr. Hutchins, by far the first authority on African timbers, though holding opinions possibly open to criticism on the administrative and economic side, points out that the general shape of Kenia is like an inverted saucer, with a snowy, tooth-like ridge in the middle. The ground rises slowly and imperceptibly up to the forest, and for the most part slowly and gradually through the timber belt. This easy gradient is of the utmost value 
for enabling the timber to be moved, either to the local saw-mill or farther. Then again, the country lying immediately beneath the forest line contains some of the finest, if not the very finest, agricultural land in the Protectorate. Along the southern slopes it is densely populated by natives, and that by a people who have carried native cultivation to a very high state of efficiency. If the neighbourhood of Njoro, and also of Pundamilia be left out, there is possibly as much cultivation on these slopes as in the whole of the rest of the Highlands. On the Western slopes there is a grand soil and climate, with a rapidly increasing white population. Even if there were no forests at all a railway to these parts would probably prove a sound commercial undertaking. When the value of the forest is added, this presumption becomes a certainty. At the present moment the British East African Government is engaged in building a railway-called a tramway, as being a name more acceptable to the Colonial Office-towards Fort Hall. At present it is projected some thirty miles through an undeveloped and sparsely populated district. All things are possible, but it is barely credible that this short branch has been initiated without the further intention of proceeding to tap those districts and those industries which are the real justification for such a line. The dealings of the Government with this magnificent property have up to the present been somewhat peculiar, or, at all events, shrouded in mystery. In 1905-6, the whole forest appears to have been alienated or leased to a syndicate consisting of Lord Warwick, Mr. Moreton Freuen and others. What their position is no one appears to know, but certainly in all this time no 
steps have been taken by them to develop their concession, if concession there be. It is by no means improbable that no definite proposals have ever been put before them to accept or decline. They appear, however, to answer the same useful purpose as $\mathrm{Mr}$. Jorkins in choking off others who are genuinely anxious to develop. Some two years ago there was a somewhat foolish and quite impracticable scheme for floating logs, or, rather, apparently sawn timber, down into the Tana; and at this time a local syndicate was approached with the offer of a concession. Since then it is understood that further negotiations with other parties have taken place. Mr. Jorkins, however, still hovers, Sphinx-like, in the background. It is seriously hoped that in the near future a definite understanding may be arrived at with one or other of the interested parties, and that work of some sort may be initiated.

The following are the characteristics of our principal timbers :-

Podocarpus Thunbergii and $P$. gracilior, the former of which is much the more common, are hardly distinguishable from the yellow-wood of South Africa. It is first-class wood for house building, and also, when creosoted, for sleepers, while it is unsurpassed as a flooring board. It must, however, be treated to last out of doors, and is not a resistant to white ants.

Cedar (Juniperus procera) is probably the most valuable tree that grows naturally in the Protectorate. It is first-class for house building, floors, roofs, \&c. It lasts both indoors and out, is disliked by all insects and more especially by white ants. It is easily worked and is splendid fuel. As, further, it is practically indistinguishable from the cedar that supplies our 
wood-pencils, it is possible that it has a further commercial use. Cedar lasts an immense time in and on the ground, and both on Kenia and elsewhere nearly as much sound timber is lying on the ground as is actually growing. Unsoundness is, however, the great drawback to the tree, and in many parts there are not 2 per cent. of sound growing trees. The trees on Kenia, and more especially on the north-west corner of the crescent, are, however, very much superior in this respect to those on the Mau.

The Kenia Camphor Tree (Ocotea usambarensis) is a splendid wood and apparently fully equal to teak. It does not, of course, follow that it would for many years command the same price, and estimates based on such an anticipation would probably prove disappointing. As in so many things, the name is everything, and merchants who want teak are not likely to be put off with a substitute, which they are told is "equally good," at anything like an equivalent price. However, up to the present no one has had an opportunity of proving or disproving their market value. These trees have been to the authorities even as an only child to its mother. A somewhat unsophisticated settler applied for a little concession in the camphor belt. A fairly high rent was proposed, but otherwise, to his surprise and gratification, the interview went smoothly enough. Not until he was leaving the door did any remark occur to damp his ardour. As he made his exit, however, a few disconcerting words reached him: "Of course we shouldn't let you cut the trees"! I must confess that my sympathies are always somewhat with the Forest Department. A great old tree is a magnificent object and irreplaceable. Every landlord knows how hard it is to sacrifice one, however 
necessary that sacrifice. When a forest of such trees is concerned the wrench must be doubly severe.

Olive (Olea chrysophylla) is a very hard, durable wood, excellent for fencing, firewood, and sleepers. It has been suggested that it may be possible to bud the cultivated variety of olive on to this tree. This has been done, not only on the Mediterranean, but also in South Africa.

According to Mr. Hutchins, in various most interesting tabulations prepared by him, the following are the estimated cubic feet of timber carried by different forests.

Timber in a normal forest of Scots Pine in MidEurope at 120 years :-

$$
\begin{aligned}
\text { Ist Class } & =9,060 \text { feet } \\
3^{\text {rd Class }} & =5,340, "
\end{aligned}
$$

The same at the age of ninety years :

$$
\begin{aligned}
\text { Ist Class } & =7,950, \\
\text { 2nd Class } & =6,100,
\end{aligned}
$$

Maximum of the South African

Yellow-wood Forests :

$$
=\mathrm{I} 0,000,
$$

Mature forest of Aleppo Pine, Cyprus = 2,02 ",

Heaviest timber areas known, e.g., Red

Wood-California, Douglas Pine--

Oregon, Blue Gum-Tasmania = 100,000 ,

These are of course all forests of great and proved value.

Against these compare the East African forests.

Southern Kenia forest

$=2,100$ feet

W. Kenia forest

$=3,265$,

Mabira (Uganda) average sample area $=4, \mathrm{IO} 2$,

Average area "Eldoma Ravine" = 6,160 "

Camphor forest, South-East Kenia = 7,945 "

Elgeyo escarpment maximum area coniferous timber

$$
\begin{gathered}
=\text { I } 5,000, \\
\text { M } 2
\end{gathered}
$$


What the value of these forests is at the present day is, of course, a matter almost impossible to estimate. Comparisons with forests of other countries are the only possible means of arriving at any result, and such comparisons are more than usually odious. One would, however, be on absolutely the safe side in saying that there exist on the Highlands one million acres of timber, worth to-day $£_{\text {io }}$ per acre. It stands to reason that the sooner this vast capital is unlocked the better it will be for every interest in the Protectorate. 


\section{CHAPTER XVII}

\section{LABOUR}

IT is not too much to say that the prosperity of a country depends almost as much on a numerous, prosperous, and efficient labour supply as on the natural resources that it can command. Though possibly the question may not be quite so acute in a Protectorate such as this as it is in a European country, yet perhaps it is an even more perplexing one owing to the many factors involved. The position is, shortly, that the employers are practically all alien, and the unskilled labourers are the original inhabitants of the land. This position gives rise to a three-sided point of view. Firstly, from what we will call the Humanitarian point of view-that is from the point of view of the man who, seated in a comfortable arm-chair in his smoking-room at home says, plausibly enough, "What a shame it is to disturb the splendid indolence of the peaceful savage! $\mathrm{He}$ is the possessor, the European merely an interloper. To allow any hardship to be borne by the former to benefit the latter, would be an act of injustice. Let us see to it that no such injustice is done." Then there is the point of view of the settler- " Here am I, a settler in this countryyou, the Government, invited me-presumably you 
knew, as I did, that I should want labour. Now I ask you to help me get it." And thirdly, we have the view of the native himself. What that view is it would take a wise man indeed to discover.

Now, of course, speaking as a settler, I am prejudiced. I hold most strongly the second view. I cannot argue with the native and therefore I must do so with the humanitarian, and to him I will put the following points :-

It is generally conceded that when we take over the government of an erstwhile savage State we confer a benefit. Any missionary will tell you that! And the man who has the votes will probably agree with him. We give peace where war was. We give justice where injustice ruled. We give law and order where the only law was the law of strength. We give Christianity, or a chance of it, where Paganism ruled. Whether the native looks on it in that light is another matter. I am afraid that possibly he doesn't as yet truly appreciate his benefits. Even in Uganda, where evidences of present prosperity jostle with the patent mutilations of the past; where the native, minus a hand or an ear severed by the order of his late sovereign, rides on the bicycle obtained through the missionary, I fear that a huge majority would, given a chance, vote for a return to past conditions. But, sir-the personal predilection of the savage is nothing to us, we stand by the deeds and opinions of missionary and Government. We have conferred a benefit on the native, now what is he going to do in return? The wishes of the People in England, as interpreted by Parliament and instructed by Government, have laid down that the native is not to be forced to work against his will-to do so would, in their opinion, 
amount to slavery, or would, at all events, inflict unparalleled hardship. In this connection it strikes one as somewhat curious that when work is mentioned as touching our fellow citizens in England, it brings up such phrases as "the dignity of honest toil," "the joy of achievement," or, in contempt, " the idle rich," "the Do-nothing Duke"; indicating, one would presume, that work is praiseworthy, idleness contemptible. On the other hand, in connection with our black brother, the former becomes slavery, the latter ideal. Surely we are getting fairly close to humbug! Does anyone suppose that the mass of our own people work for love? Of course not. They work because they are forced to work-not, certainly, by direct fear of whip or prison, but through keener incentives. The spur of actual hunger urges on the main body, while the comparative few whom good fortune-or their own efforts-have made independent work to keep the position they have acquired or to retain the respect of their fellows. This state of things is the result of the highest civilisation we know ; that civilisation must and will see to it that the native does his fair share of work with the rest of humanity.

Probably at the present time our Protectorate stands in as good a position for native labour as any part of Africa. In the Highlands alone, as we have seen, there are $2 \frac{1}{2}$ millions of natives, and considered as a whole they are strong and intelligent. . It may be taken as quite certain that if the adult population worked for three months in every year, it would be many years before the labour supply could be insufficient. Nevertheless, in the past we have had our labour difficulties, and one may be quite certain that they are not yet over. Many causes naturally contribute to this, but 
the main one is the old law of supply and demand. Firstly, the demand is not regular. Certain crops, such as coffee, require for harvest large gangs of labourers, but during the rest of the year comparatively few. Then again the Public Works Department or some large private enterprise may make an extraordinary demand on the resources to hand. Such cases would be the construction of the Fort Hall tramway by the Government or of the Magadi Railway by a public company. The supply also is not constant. The various labour-supplying tribes have large Reserves allotted to them-perhaps too large. In these the natives cultivate crops. When these crops are good, they produce a considerable surplus of food, which is sold and goes towards paying the taxes imposed; consequently, the labour supply is less when the crop is heavy than when it is light. Every year a greater area of these Reserves is put under cultivation and that under a more valuable crop, and though the native population is also increasing, probably the labour supply tends at present to get smaller. It will not be until these Reserves are either completely filled up, or else reduced in area, that anything like a constant labour supply can be calculated on.

Some five years ago, owing to various causes-the principal one being a very heavy native crop-there was a considerable shortage of labour. The settlers held various meetings and expressed their views in the loud and indignant manner that is common to all Colonials, and indeed not unknown at home. Naturally the Government came in for abuse and the very generally expressed sentiment was this: "The native won't work; he must be made to work, 
and anyone but a fool knows that the only way to get the native to work is to raise his hut- or poll-tax." Almost directly afterwards I had occasion to pass through Rhodesia. There I attended a mass meeting of farmers called with respect to labour, which was then both scanty and expensive. This meeting was equally heated and indignant with the authorities. They almost unanimously expressed this sentiment: "Anyone but a fool would know that to increase the hut- or poll-tax will not increase the supply of labour, but only the rate of wages!" It would seem, therefore, that there is no royal road to control the supply of labour. The East African native is at present an improvident creature and his wants are simple. All he wants is enough money to buy food to eat and enough to pay the light taxes imposed on him. Therefore when he has made what he can out of his crops, a certain surplus remains to be found and that represents the available labour supply. Thus we will say that in a certain area to supply the simple wants of the native population and to pay his taxes Rs. 200,000 are required. Of this sum Rs. 50,000 are found by the sale of surplus crops, etc. This will leave Rs. 150,000 which has to be earned by manual labour, or, at Rs. 3 a month, 30,000 men working one month. If this supply more or less corresponds with the demands of adjacent employers, all is well. If, however, the demand is insufficient, either the price of labour will go up, or, as is probable, the surplus labour will go further afield. If, on the other hand, more labour is required, the employers must either themselves go further afield or find some inducement to increase the local supply. One thing seems certain at present, and that is from that district you 
will get during that season 150,000 rupees' worth of labour, neither more nor less. As time goes on the native will get to appreciate luxuries, such as better clothes, better food, etc., and then it would seem that the labour supply will be more elastic. Certain points strike one as giving proof that the present large Reserve system is not entirely satisfactory. The whole manual work inside the Reserves is done by women and children. Nearly the whole labour supply outside is done by the sickly, the undersized, or the old men. The class which in a civilised State would be regarded as the bread-winners, are here represented by brawny savages, covered with grease and oil and carrying enormous spears. This very large body do nothing, and exist on the efforts of their women-kind and weaker brethren. They offer a certain menace to the prosperity of the country. It is this class who ought and some day will be made to do their fair share of work.

Again there are certain districts where various crops grow well, but where there is little local labour available. This is the case on the Uasin Guishu plateau and on many parts of the coast. Here labour has to be imported, and that it may be induced to come, various attractions, monetary and otherwise, are held out. On this imported labour the Government keep, and rightly so, a very careful watch. Those portions of the Protectorate which were originally not inhabited by natives were left barren for definite causes; in some instances it might be for fear of warlike and aggressive neighbours, in some perhaps through fear of wild beasts, but in some in all probability because the climate was found prejudicial to health. The question is a delicate one, but at all events it may be said that the movement of natives, like the Kikuyu, from the cool uplands to 
the hot and feverish coastlands, requires very careful watching. There has already, unfortunately, been a considerable mortality.

There is not in the country at the present day any labour bureau on any co-operative basis. In 1909 and I9I0, Mr. T. R. Swift brought forward a scheme for instituting such an organisation. The scheme was well received, but fell through owing to various causes. Mr. Owen Grant subsequently drafted a similar scheme, but it shared the fate of its predecessor. The reasons which have militated against the successful formation of any such organisation are probably as follows: Firstly, the labour crisis has never yet been sufficiently acute to stimulate united efforts. Good masters have, except in rare instances, been able to obtain the labour they require. There has been a lack of sufficient funds to start a bureau on permanent and satisfactory lines. Until the necessity is imperative every available penny of capital is required for development. Finally, many of the up-country settlers felt that they would be forging a weapon which the planters on the coast might use against them. Conditions are so very different on the unhealthy coastlands where money can be made and quickly made, but where no Englishman can make a home, from those on the Highlands, which it is now safe to assume will form the habitation of a permanent white population, that there is bound to be acute competition between the two. The argument that because we are one Protectorate our interests are indivisible does not seem to me a sound one. I confess that I hope to see before long an institution to protect the labour interests of the upland farmers and also another to uphold those of the planters. Finally, I would draw 
attention to the fact that there are some employers who can always obtain and keep labour, while others can never do so. What is the secret of this ? I must always confess that it is an absolute mystery to me, and that I know of no golden rule. One man will tell you that the great secret is to keep one's temper. It is not so. We all know cases of men of ungovernable temper who are yet most popular with the natives; of others, again, possessing most equable tempers, who are equally disliked. One employer, a successful one, will tell you that the great thing is to talk and joke with his men, get interested in their wives and children, and learn their personal feelings. His equally successful neighbour swears by the policy of holding religiously aloof from all personal intercourse. This man says it is a fatal thing ever to strike or beat a native. That man, that a wholesome use of the "Kiboko" is essential, and, in fact, adds his black brother to the category of the spaniel, the wife and the walnut-tree. There is, I believe, only one point on which all are agreed, and that is that what the native really appreciates is a sense of justice, and that if he once thoroughly grasps the fact that you are really trying to deal with him fairly and impartially, he will stand a good deal. On this point, I think, all successful masters are agreed, and I think that a majority would agree on the following points: That it is essential to pay up wages on the very day they become due. You may be sure that the native knows the exact day on which they are due, and appreciates being paid on that day. That where possible piece work is desirable, failing that, task work. That labour living on a farm is preferable to that imported. That where possible it pays to see that your labour is 
properly housed and fed. That fines are not desirable unless the fine imposed on a delinquent is handed over to the other labourers. That repeated beatings have a bad effect, but that when it becomes necessary the beating imposed shall be thorough. I am well aware that this view is not popular at home, but am personally convinced that for certain crimes, such as lying, petty stealing and more especially cruelty to children or animals, the whip is the best and kindest preventive and cure, and that the native labour should participate to some extent in a successful crop. A plan has been adopted by Messrs. Swift and Rutherford, of Punda-nulia, and by their neighbours, Sisal, Ltd., which has much to recommend it. The white employer breaks up and thoroughly cultivates a field. He then supplies natives with seed, which they plant, keep clean, and reap. The employer then buys back the crop at a price agreed. The advantage to the employer is that he is saved the supervision of gangs of labourers. The advantage to the native is that he participates in the fruits of his successful work. The disadvantage to both is that the temptation to steal the crop and sell it for its full value elsewhere is unduly great.

Taking the labour question as a whole, I believe that, though undoubtedly the Protectorate has certainly both trials to go through and difficulties to overcome in the immediate future, there is no part of Africa in which the ultimate outlook is better or more assured. 


\title{
CHAPTER XVIII
}

\author{
MINERALS
}

Any notice of the Minerals in the Protectorate must necessarily be a short and inadequate one, because up to the present date it may roughly be said that, like snakes in Ireland, there are none.

This is not to say that there are no minerals, which would be a bold statement to make in a country which is as yet so far from being thoroughly explored, and in which prospecting has been done only in the most amateur and unsystematic fashion. It is true that the Government has in the past had a Department devoted entirely to the subject of mines and minerals; but the efforts of the office appeared, of course to the uninitiated, to be devoted mainly to devising penalties and spoliations for the benefit of anyone who might be unfortunate enough to discover a paying deposit. At all events, either fear of the results or a patent unlikelihood of workable gold has prevented the arrival of any quantity of skilled prospectors. It is therefore impossible to speak with any certainty as to the possibilities of paying minerals outside the settled area. In the settled and healthy Highlands it is, however, probably safe to say that judging both from the volcanic nature of the formation and from the 
discoveries, or rather lack of discoveries, of prospectors and farmers, there are unlikely to be any of the more common minerals in payable condition and quantity. There are many who will be inclined to agree that this is very far from being a misfortune. Most mines, and more especially gold and diamond mines, though adding revenue, bring a class of immigrants who are not likely to add to the peace and happiness of an agricultural country. There is, moreover, every probability that the Protectorate will show once again that agriculture, under the best conditions, will prove the surest and most satisfactory source of wealth and prosperity that exists.

As in most parts of Africa, there are many traces of gold in the Protectorate and the presence of these and also of diamonds, very small and very scarce, have raised the hopes of many a settler. Well do I recollect seeing a well-known professional hunter of elephants and other big game spurring a dripping horse up to our farm. Pouring with sweat and inarticulate with excitement, he assured us that he had found gold. It appeared that while hunting in a range of hills some twelve miles off he had been overcome with thirst and vainly sought water for some hours. At last, to his joy, he found a little pool and put his head down to drink; no sooner had his lips touched the water than, in his own words, "I saw that the pool was paved with gold, all gold! it was like drinking gold!" In the usual generous fashion of his type, he promised us all a share of his colossal fortune, and, hardly waiting for a drink, was off at a gallop to register his claim in Nairobi, some forty miles off. Alas! our old friend once again : Iron pyrites. Such is an instance of one of the many disappointments that have befallen 
the optimistic and ignorant, and even the common ant's egg shining in the clay has raised the hopes of the tiller of the soil, only to be ignominiously squashed in the office of the mining expert. In cases where the discovery has had better grounds to justify it, it has usually been followed by a rush to the scene of the find, where a day or two's search, a night or two's jollification, a good deal of claim-pegging, and a small amount of disappointment, have sent the would-be capitalists back to the less exciting but surer occupations in which they were previously engaged. The most famous of such rushes was that following the discovery of one or two very minute but genuine diamonds along the N'darugu river on the way to Fort Hall. The whole population of Nairobi left shop, office, field, or forge, and on horses, mules, bicycles, carts, or even on foot, migrated as fast as possible to the scene of the discovery. On arrival they pegged out claims for a distance of many miles north and south along the road; though why along the road I can't say. Little serious work was done, indeed it is doubtful whether five per cent. of the crowd would have recognised a diamond had they been fortunate enough to find one. But one eminent citizen did well, and it is his example that I would 'most earnestly commend to the young settler. Wasting no time over claims and peg-driving, this practical soul filled a waggon with beer and proceeding to the scene of the mining operations sold the contents at a profit of several hundred per cent. The proceeds of his enterprise, great as they were, would have been finer still had his friends been fewer and his heart less generous.

Next to the gold and diamonds, coal has proved the most alluring Will-o'-the-Wisp. Rumours of magni- 
ficent finds arrive periodically, usually from the coastlands, presumably because they are less easily verified in these districts; and more than one company has been formed to acquire and float the splendid properties. Gentle settler, beware of these companies! The origin of one discovery does more credit to the brains of the down-country native than to those of the upcountry Englishman. A smart Swahili, having acquired a chunk of coal in the neighbourhood of the Docks, retired with it into the bush. Some days later a travel-worn native, scratched by thorns and limping sadly, reached Mombasa. On his head was a black lump wrapped in grass. He had knocked it off a huge uncovered mass of the same substance, and thinking that it looked like the stuff the Mzungus (Europeans) burn on the big boats, he had brought it in. The Englishmen to whom he showed it looked, and lo! it was coal! Their fortune was made! Would he with the utmost secrecy show them where he had made the great discovery? For a consideration he would. A fair sum now, and more later? Yes, if in addition there was a further sum to buy an outfit. The money passed hands. The native went to procure the outfit. Presumably he is still looking for it.

While, however, no minerals have as yet proved workable in paying quantities, there is one substance which is already proving of great commercial value to the Protectorate. This substance is, I presume, more chemical than mineral, but may nevertheless well be included here. I refer to the great deposit of crystalline soda in Lake Magadi, by far the finest known soda lake in the world. Though for many years the presence of this lake has been known, and 
though it lies near Nairobi--only some 60 miles to the south-west-it had until recently been comparatively little explored. (To whom the original discovery was due I am not sure, but among the first to visit it were Mr. V. M. Newland and Captain Riddell.) The reason of this is that not only is there no surface water within many miles of the lake, but the approach to it in every direction is through singularly barren, difficult, and waterless country. The value of the soda has long been realised in the country and more than one option has been taken on it, but until I 909 the great cost connected with extracting and transporting the soda to the coast had prevented its exploitation. In that year a large expedition was formed under the auspices of Messrs. M. Samuel \& Co. to examine the commercial properties of the soda, with a view to its acquisition. The principals of the party were Messrs. W. H. Levy and A. E. Herz, with Captain Shelford as consulting engineer and $\mathrm{Mr}$. A. Trobridge as chemical expert, the whole being under the guidance and organisation of Mr. H. F. Ward. The results of the expedition, which was splendidly managed, exceeded all expectations. Captain Shelford discovered a route for the railway in which the engineering difficulties were comparatively few ; $\mathrm{Mr}$. Trobridge reported that at a low estimate there were 200 million tons of crystalline soda of extraordinary purity, and that moreover this soda might by a very simple process be converted into a soda ash equal in chemical purity to any on the market. The result has been the formation of a huge company with splendid prospects before it. The branch railway is already under construction.

The lake itself merits a word or two of description. It is some 15 miles long and has a total area of more 


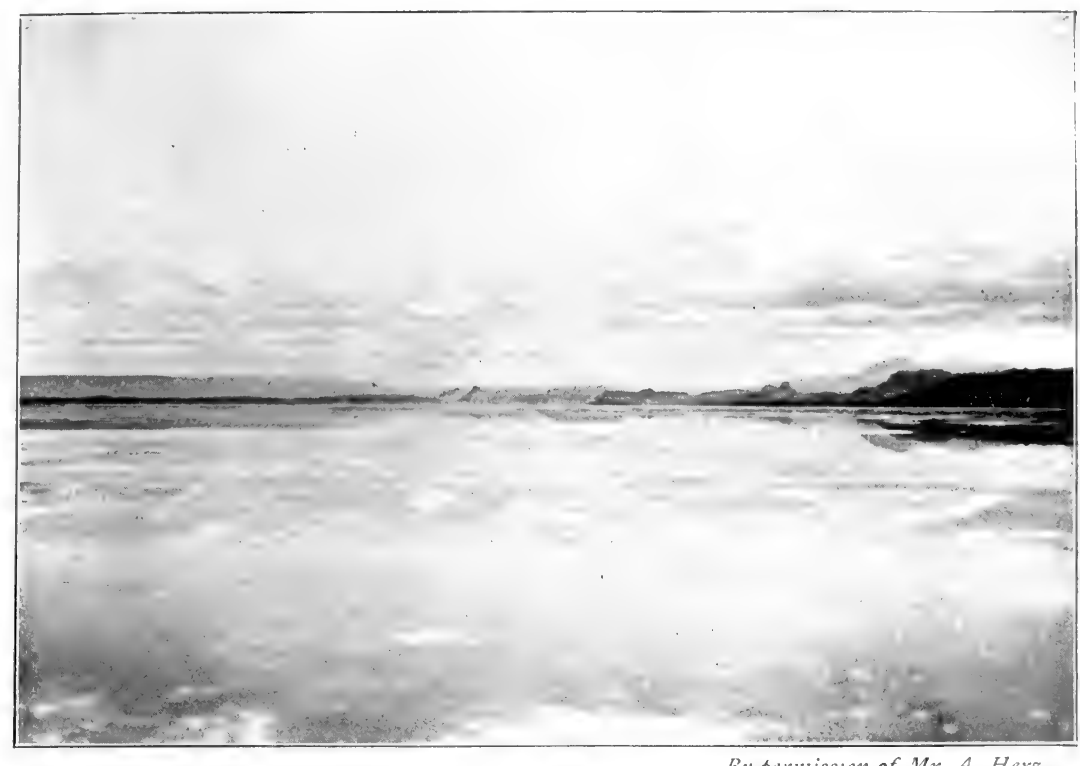

MAGADI SODA LAKE.

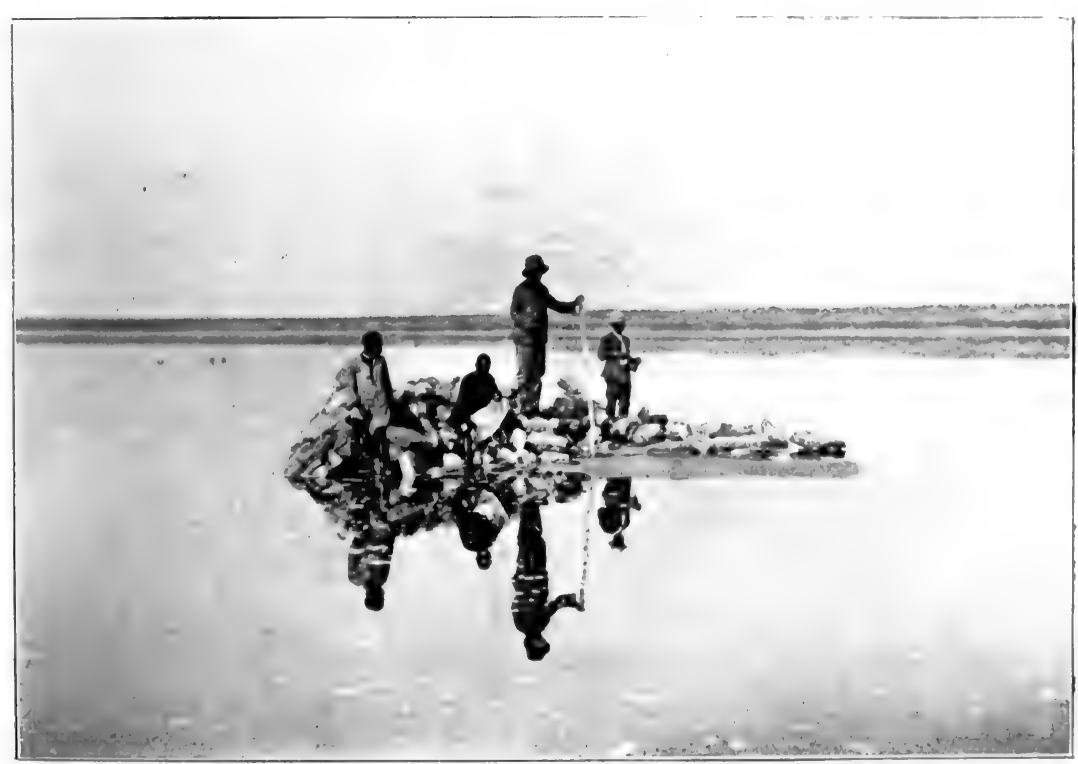

By permission of Mr. A. Her.

Magadi Lake: Digging out the Soda. 

than 30 square miles. In a normal condition it appear as if it has frozen, and that then snow has fallen, that the snow has then partially thawed and frozen solid again, giving that surface which all English skaters know to their disgust. The temperature gives the lie to this appearance of ice, as the heat is extreme, and on the lake in mid-day almost unbearable. The soda burns the feet right through a boot, and the crystalline spikes, for all the world like hoar-frost, will pierce any but the thickest sole. After the rains there is a layer of water over the greater part of the lake which turns a lovely pink colour, giving the whole a wonderfully beautiful appearance. By moonlight the scene is most weird and never to be forgotten. It appears at such a time as if one was looking at an arm of the sea on which one can almost swear to a gentle swell.

Another 60 miles further to the east is another and much larger soda lake, Lake Natron, the great bulk of which is in German territory. The soda deposit in this is of a very inferior quality, and there is a much greater proportion of mud and water. At the time I visited it, its shores were the haunt of almost innumerable buffalo, lion, and antelope, and its waters of quite innumerable flamingoes, herons, ibis, and other birds. 


\section{CHAPTER XIX}

TYPE OF SETTLER REQUIRED

An attempt has been made to show some of the possibilities and prospects which British East Africa affords. Now we would ask what qualities and accomplishments the Protectorate in return demands.

At once it may be said that with the exception of the wastrel and the degenerate all are welcome. We want the capitalist, we want the skilled workman, most of all perhaps we want the man with a small capital who will bring out his wife and make a home.

To those who mean to work, most branches of life are already open. In the towns, and more especially in Nairobi, most European shopkeepers and merchants do well. It is true that there is the competition of the Indian to be faced, a competition which, as I have shown elsewhere, is at present an unfair one. Still, even now if shopkeepers will supply the best goods, employ the best business methods, and ensure politeness, prompt delivery, and reliability, they need not fear the shoddy goods, the sweated labour, and the small margin of profit with which they are met by the lower race.

All skilled artizans do well and the supply is by no 
means equal to the growing demand. This more especially applies to skilled mechanics and engineers, for the latter of whom there is at the moment an exceptionally fine opening.

Here as elsewhere the legal profession fatten on the folly of the litigious; indeed it would be hard to find a corner of the globe in which so large a proportion of savings and earnings finds its way into the cashboxes of the lawyer. I always put down a great deal of this spirit of litigiousness to the tropical sun, which causes tempers to run high and men to see offence where none was meant. The sun, tropical and otherwise, cannot, however, be held responsible for the extraordinary muddle into which land-titles both in the Highlands and more especially on the coast have been allowed to lapse.

But it is to the farming class that British East Africa makes its strongest appeal. Here again, as long as the candidates are genuine, all are wanted and will find their niche. The big capitalist is wanted to stock and develop those stretches of country which do not as yet, if they ever will, lend themselves to closer settlement. Where he is especially needed is for plantations, forests, sheep, and cattle ranches. With the capitalist we want his bailiffs, his foremen, and his employees; the more the merrier. There are some who dislike the capitalist or company, as the case may be ; and would seem to assert that the man who works for another is not so good a man or such a credit to the State as one who works for himself. This is a small view, and certainly contrary to experience. I have found, and it is a matter of common knowledge, that those who are, so to speak, "in employ" and earning salaries or wages are every bit as good, 
honourable and independent men as those who are resident proprietors.

Again, we want the small farmer badly, and perhaps, where conditions suit, his is the most desirable position of any. What his social class or position was when he left England matters not a jot. On his arrival he takes rank solely as a man. What is wanted is industry, honesty, and the more capital the better. For this position there is one class at home to whom this country seems especially suited and that is to the public-school boy.

We who are living out in this Protectorate have read with mingled disappointment and satisfaction a considerable flood of articles in various magazines giving expression to the opinion that our muchvaunted public-school boy is little better than a drug in the market, and, to speak plainly, not wanted in our older Colonies, more especially in Canada and Australia. The disappointment has been caused by the shattering of the illusion that, in spite of a thoroughly unsuitable education, our public-school product was fit to go anywhere and do anything. Our satisfaction is the result of the feeling that we have here at the present moment a practically unlimited field for this surplus class which the older Colonies despise. In fact, one might go almost so far as to say that those very qualities which render him superfluous and antagonistic to our Canadian and Australian cousins are the very ones which cause him and this Protectorate to be almost ideally suited to each other.

That the product of our great public schools is not in the main suitable to the more advanced of our colonies is a statement that one fears it is impossible to deny (though Mr. Lloyd George's opinion that in 
Australia they hang the scions of our upper classes to the nearest tree is, one hopes, merely another political exaggeration). Why is this? As I read them the charges against our friend amount to these :-

That he arrives out from home with a great and entirely unjustified opinion of himself.

That, though keen, active, and tireless at games or sport, he is physically incapable of and unwilling to do continuous manual labour.

That his ignorance of all farming and practical matters is colossal and complete.

That he holds certain kinds of work menial and objectionable, more especially the cooking of food and making of beds after the day's work is finished.

That he is not companionable and makes no attempt to throw himself into the conditions of life in which he finds himself.

To this the public-school boy retorts :

That he has been taught, and he believes rightly, to hold himself the salt of the earth, and that from his inspection of the colonist he sees no reason to change that opinion.

That the life offered in these Colonies is one long drudgery, relieved by very few attractions in the way of sport or amusement.

That on his return from a long day's labour the worst task remains to be done in preparing his lodging and cooking his food; with the result that he frequently goes to bed insufficiently, or rather unsuitably, fed.

That, though he freely admits that the native-born with whom he associates are first-class fellows, he nevertheless has little common ground with them, and that from his point of view they are imperfectly educated. 
These would appear to be the main charges and counter-charges. As to their respective merits, it is not for us to say, probably there is an element of truth in each. At all events, the result is, with, thank heaven! many an exception, the comparative unsuitability of the class for our older Colonies. Nor is the reason of this far to seek. For three hundred years or more the whole aim of a public-school education has been to fit a boy, not for work, but for the overseeing of work. Until comparatively recent times, for the sons of gentlemen, and more especially of country squires (which class formed the huge bulk of the public school), there were but three careers: the overseeing of the estate itself for the eldest son; the Army, which then demanded little or no expert knowledge; and the Church, which amounted to the overseeing of the parish and the position of the squire's right-hand man. Even when, say about the middle of the last century, the merchant class began to invade the public school, it was customary, after a very brief period of probation, for the merchant's son to take up the position of partner rather than apprentice. To this end, therefore, i.e. that the finished product might become an efficient overseer of labour -was the whole system of education directed. And well, indeed, it served its purpose. I venture to say that never again will England see such good landlords, such good magistrates, such good clergymen, or such splendid leaders of soldiery, as she saw last century. But times have inevitably changed, and in the main, of course, for the better ; at all events, the design of giving a more equal chance to every human being born into the world is a great one. To be a landlord at all now is next door to a criminal offence, 
while in every profession the tendency is rapidly growing to have at the head of affairs those who have been through the mill from the very bottom. But, one would ask, how far has the curriculum afforded by our great public schools been altered to meet this change? In the main hardly a jot, and it is almost a truism to say that an ordinary grammar school education fits a boy for the struggle of life better than six years at Eton. Here, then, we see turned out year by year a large and ever-increasing class, containing in many ways the very cream of our manhood, for which there is at home an ever-decreasing demand, and which, moreover, we find to our dismay our oldest and finest Colonies do not appreciate.

Luckily, the world is large and opportunities are great, and there still remain vast tracts of country where what are held to be the very faults of his education will prove to be valuable assets. Of such countries, second to none rank the Highlands of British East Africa. And why? Because it is, I venture to affirm, in the face of inevitable criticism, essentially an overseer's country. In saying this I have no wish whatever to deter any class of skilled labour from entering the country. On the contrary, I doubt if there is any country in the world where the skilled workman or mechanic is more sure of a good living. We have here a great stretch of splendidly healthy country. There is thereon a large and rapidly increasing native population, who always have done and always will do the actual manual labour connected with a farm. Most of these natives are moderately lazy, barely moderately honest, and decidedly intelligent. With a good master they form distinctly good servants; and I think that undoubtedly the best 
master and the one whom they prefer is the old publicschool boy. His very faults, as I have said, are in his favour. Thus, he has a great, perhaps an exaggerated, opinion of himself; this opinion is apt soon to be shared by his natives, ever prone to take a man at his own valuation. Again, he spends, perhaps wastes, much of his time at sport, but this is appreciated on the farm, where many of the labourers are, when they get the chance, hunters themselves and practically all are voracious eaters of fish, flesh, and fowl. His very ignorance of farming is far from an unmixed evil in a land where conditions are so new, where so much has to be learnt afresh, and so many old theories are absolutely discarded. And then those virtues which furnish the hall-mark of his caste-honour, scrupulous fairness, temper well held in check but not dead, and last, but far from least, a sense of humour-endear him most of all, and enable many a man to obtain and hold labour for which his neighbour, perhaps in many respects the better man, offers in vain a higher wage.

Let us map out the opening career of a young man of, say, twenty-one, who on leaving the University decides to come out to the Protectorate. In the first place, I would strongly advise him to continue-and in this case it would really mean continue, and not recommence-his education by entering some large estate or joining some old school friend as a pupil. There are plenty such who would be ready and willing to take him, board him, and teach him at from $£$ IOO to $£ 200$ for a year, which sum the experience gained would far more than repay. He will be wise if he selects as the scene of his pupilage a farm where as many different branches as possible are 


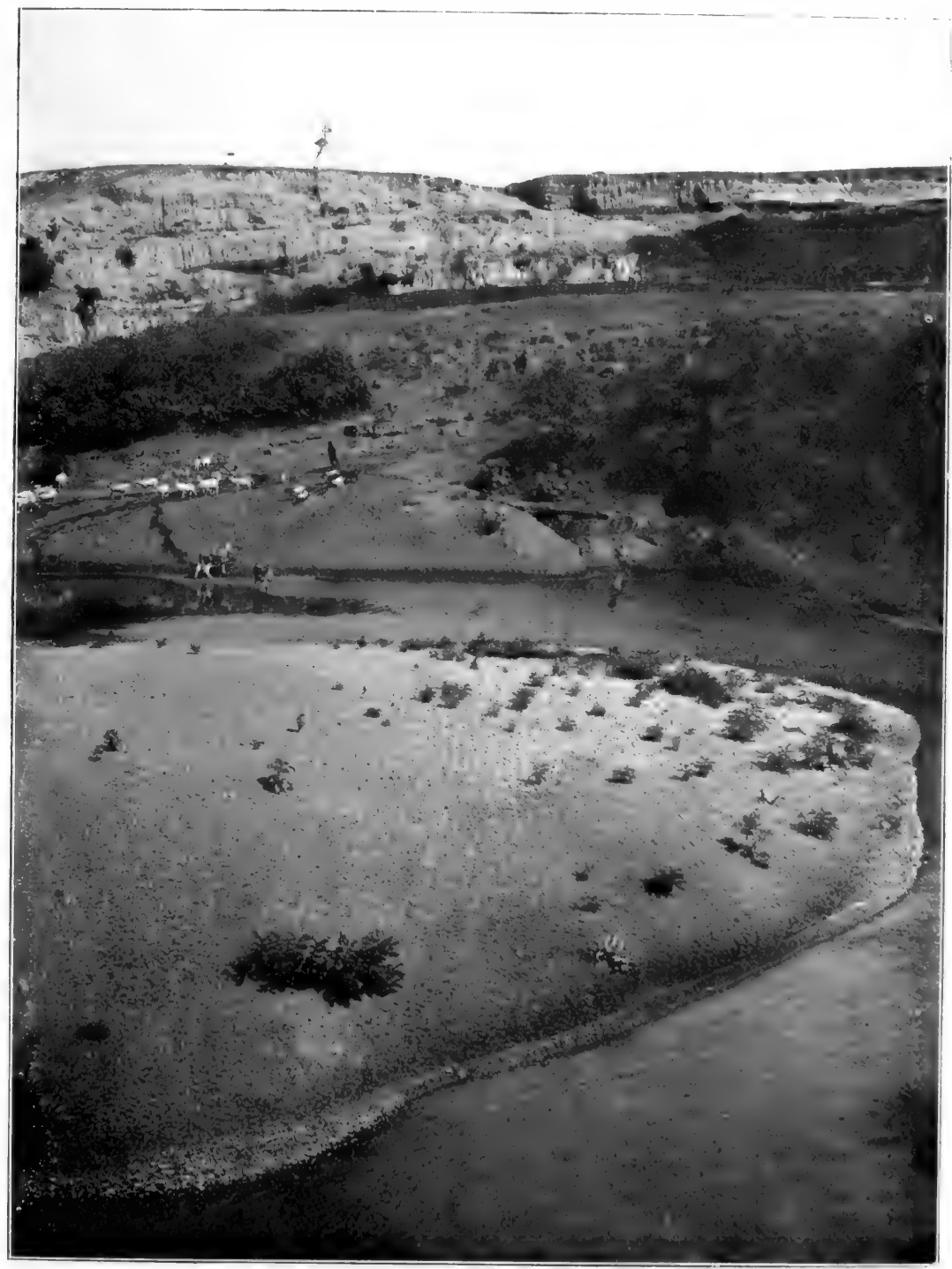

lhoto by R. J. Sterd's.

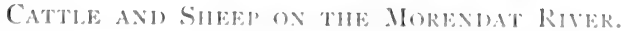



carried on, for though two lines may be equally profitable, a man's bent may lie in one rather than in another. These twelve months should teach much; in addition to actual farming and agricultural knowledge, there is the learning of Swahili, the universal medium of conversation with the natives, there is the management and breaking of oxen, the right method of handling native labour; and, finally, our friend will learn, if ever he is to do so, his own strength as opposed to that of the tropical sun.

At the end of twelve months the pupil should be in a position to start work on his own ; and here I would point out that it is both more economical and more pleasant for two friends to join partnership and work together. Let us imagine two such friends starting together, and see if we cannot give a word or two of advice. First as to capital : I look on $£ \mathrm{I}, 200$ as an irreducible minimum. If the settler or settlers arrive with less let them work or trade until this sum is acquired, but to start farming on any smaller sum means one continual and wearing uphill struggle, with the certainty that a single bad season spells ruin. Next as to land: most Englishmen know what landhunger is, and the pride of possession is no doubt a very fine feeling; but I would warn anyone against acquiring a large tract of country far from the line. For such a one pride of possession and hopes for the future will be the sole sustenance; the very heavy cost of transport both in and out will devour all other profit. Better it is to buy a small area in an easily accessible district; best of all, perhaps, to obtain an area from some large estate on easy terms. Rent could be payable on a percentage of the crop and an option to purchase at any time obtained. We will imagine 
our friends to adopt this last course. They must then have a house; and here to be penny wise is to be pound foolish. A good house is essential to and almost a guarantee of perfect health. If stone is easily available let it be built of stone; if not, of cedar-wood with a shingle roof. In either case a nice little house with a sitting-room, two bed-rooms, and a deep verandah will cost, roughly, $£$ I50. A kitchen, a hut or two, and a rough store will be $£ 50$ more. While the house is going up we will have two hundred acres ploughed up by contract. There are plenty of contractors, both Dutch and English, who will do this, and the cost, unless the clearing is very heavy, to clear, plough, and cross-plough will not exceed $30 s$. an acre, or in all $£ 300$. The advantage of contracting is this : cultivated land should lie fallow through one rainy season, and therefore by contracting a breathing-space is given in which to buy ploughs and implements, break oxen, and obtain labour. Ploughs, implements, and a Scotch cart will come to $£ \mathrm{IOO}$, twenty oxen at $£ 4$ each will be a further $£ 80$, and four good sows, and a boar perhaps $£ 25$ more. A cattle boma and rough pig-styes will bring the capital expenditure to $£ 685$, or, as numerous small items such as furniture, at first necessarily of the roughest, have been omitted, say $£ 730$. We have thus left $£ 470$ for living expenses, twelve months' working expenses, and, if possible, some small insurance against a bad season's crop, a sum just, but barely, sufficient. Living expenses will be managed comfortably, certainly not luxuriously, on $£ 100$; labour I put at $£ 7$ a month, and $£_{23}$ for the harvest month; $£_{200}$ will be kept in reserve; and the remaining $£ 70$ will surely go in repairs and unforeseen contingencies. 
Now as to the return, necessarily small, for the first year. As I have said, for one rainy season the ground should lie fallow ; a few mealies may, indeed, be sown broadcast for pigs or cattle to feed off, but no return can be expected. Before the next rains the ground will be again cross-ploughed, and we would advise, should the land be suitable, that it be planted entirely with either Rose Coco or Canadian Wonder beans. The yield of either variety is up to one ton per acre, but as the soil is not yet thoroughly in order we will not put the whole crop at more than fifty tons, worth on the farm about $£ 7$ per ton, or $£ 350$ in all. Let the rent be taken at $£ 50$, and the net position at the end of the year will be as follows :

The $£ \mathrm{I}, 200$ capital will be reduced to $£ 700$, but our farmers will be in possession of a house and implements, oxen and buildings, we will hope of some twenty or thirty sows and store pigs, and of two hundred acres of thoroughly cultivated land, which should be safe to produce a net income of $£ 600$ per annum. The next year should see the addition of perhaps another hundred acres of cultivation of at least two more teams of oxen, and possibly the nucleus of a small herd of cattle. The alternative crop might be wheat, maize, peas, lucerne, and possibly ten acres put down in black wattle or coffee. At the end of this second year a net income for the ensuing year of $£ 800$ may be confidently anticipated, and at this point we will leave off, I hope well satisfied as to future prospects.

What is the daily life on the ordinary small "mixed" farm? The farmer rises with the first streaks of dawn and hurries out at six o'clock, when the labourers will be mustered and apportioned their allotted task for the 
day. Once out of bed, always a wrench, this is one of the pleasantest hours. The sun has just made his appearance and every blade of grass and twig of tree is clad in diamonds. It is deliciously cool or bracingly cold, according to the season. Those who assert that flowers in Africa cannot smell would soon find out their mistake in the perfume which pours from roses, violets, and mimosa. Partridges are calling in all directions, and the last wail of the hyæna, or, if one is lucky, the deep grunt of a lion may be heard. Unless the view is obscured the heights of Kenya and Kilima-njaro stand clear-cut pink, white or blue. In a word, this is one of those moments, always rare, when it is good to be alive.

A few appreciative sniffs, however, is all that our friend will get, for as he approaches his little knot of "boys," a strong smell of raw Kikuyu and mutton fat dissipates all lesser scents. He therefore as quickly as may be calls up the foremen or "Neoparas" and lays out to each the day's work ; insisting if he is wise as far as is reasonably possible on piecework. Thus, one gang will be employed in cleaning and weeding a certain area, one Scotch cart and three or four boys will be going to collect a fixed amount of firewood, two strips are marked off to be ploughed, and so on. The day's tasks being settled, the farmer sees the oxen harnessed and the various gangs commencing work; he then returns for a wash and a shave and so to breakfast at 7.30. This very solid meal over, one partner will go off to supervise the work and probably take a hand at the ploughing himself; his friend meanwhile will go round the stables, the pigs, and the cattle. There are then assuredly some carpentering jobs to be done, ploughs or carts to be repaired, or a fence to be erected. 
Luncheon will be at noon, and at this meal it is likely that some neighbour may drop in to ask for the loan of some tools or to arrange for some joint wagon to go into town to take in produce or bring out stores or implements, or with news of lion or buffalo for a Sunday's jaunt. At four o'clock the gangs knock off and tools and implements are replaced. Tea is taken and afterwards till dark is the hour for recreation. This may take the form of gardening or a game of lawn tennis. It is not unlikely that there is a pony in training for the farmers' race at the next meeting, perhaps a couple of polo ponies to be exercised, or possibly the larder may want replenishing. Darkness falls all too quickly and at 6.30 a bath and change into pyjamas is the order of the day. At 7 dinner-soup, buck, partridge and pudding, not by any means forgetting whiskey and a glass of port. Then with a pipe comes the writing of a letter or two, the filling in of the day book and possibly the balancing of accounts. At nine o'clock, healthily tired, we call to our dog and turn in.

Not a very exciting day, you may say. Perhaps not, at all events to read of; but entrancing enough to the man who sees his holding steadily grow, watches his crop spring up and grow ripe, struggles monthly with the elements, with insect perils, with possibilities of disease among his stock; struggles and usually wins through. 


\section{CHAPTER XX}

\section{THE UGANDA RAILWAY}

IT may be confidently stated that, in proportion to the goods or passengers that it carries, more has been written about the Uganda Railway than of any railway in the world. The traffic manager must often wish he could charge freight on the amount of literature under which it labours. Nevertheless, in spite of this previous overdose, no work which deals in any way with the Protectorate can be complete without reference to the line, if only for the fact that without it there would have been no Colony.

The construction of the railway itself is owed to the Anglo-German ageement and to the "General Act of the Brussels Conference" in 1890 . When the British East Africa Company in 1892 found that in attempting to administer and occupy Uganda they had, speaking vulgarly, cut off more than they could chew, and requested the British Goverment to relieve them of their obligations, it was absolutely touch and go whether or not we abandoned the whole territory. In all probability we owe our retention of this splendid tract mainly to the missionaries who were then working in the country. As a result of their representations, Sir Gerald Portal was sent from Zanzibar in 1893 to 
make a report, which report led to the formation of the Uganda Protectorate in I894 and of the East Africa Protectorate in 1895 . At the same date, the construction of the railway was decided on "to represent the contribution of this country to the execution of its obligations under the Brussels Act." Seldom has such a lofty moral view prevailed by such a narrow margin, or when it has prevailed been received with such a universal flow of abuse.

The work of construction actually commenced in December, I895, and the first train reached the Lake Victoria in December, I90I. The line was handed over to the Protectorate by the construction committee in October, I903. The railway is Stateowned. The cost was roughly $5 \frac{1}{2}$ millions and was raised on terminable annuities at 3 per cent. which will be all paid off by the year 1929.

With regard to the actual construction and the technical skill with which it was conducted there have never been two opinions. It was a finely conceived and splendidly carried out piece of work. With regard, however, to the cost of the same opinion is diverse. This division of opinion is of recent date, and is satisfactory inasmuch as up to the view stated by the present Governor that the cost of construction was strictly moderate, expert opinion seemed to be pretty well unanimous that it had been excessive. Sir Percy Girouard's reputation and knowledge of railways stands so high that his opinion, even at so late a date, must almost counterbalance the mass of previous expert opinion with which it is in conflict. Certainly the writer has no intention of arguing the point. Three considerations, however, must be borne in mind. Firstly, that the estimate of the cost pre- 
pared by four very able Royal Engineer surveyors was only $£ 2,240$,000, while the actual cost has been more than $5 \frac{1}{2}$ millions. Secondly, that the construction was supervised by a body whose composition cannot possibly have been conducive to economy. This body was composed of representatives of the Foreign Office, Treasury, Crown Agents, an expolitical agent and two retired Indian officials, who, though most distinguished in their own lines, were, with one exception, absolutely ignorant of technical railway work. Moreover, they did not act in conjunction with the Protectorate Administration, but rather to a great extent in direct opposition. Thirdly, a cost of $£ 9,3$ I 4 per mile through country the large bulk of which did not present any exceptional obstacles cannot be prima facie held strictly economical. Sir Charles Eliot, with all the particulars fresh before him, says: "Everyone who has an adequate knowledge both of the country and of the history of the construction is agreed that the line ought really to have cost about four millions sterling."

Whatever may be the exact truth of the economical merits of the original construction, there are no two opinions with respect to the efficiency of the present management. I have often asked various settlers which Government Department they considered the best run in the country-if with a liver temporarily disarranged the question perhaps took the form of "least badly" run-but in either case the answer was almost invariably the same. The railway undoubtedly. No praise can be higher than this; for by its nature the railway must tend to be rather antagonistic to a farming class. That is to say, farmers and exporters must always be trying to get freights cut down 
to a figure below which they cannot be carried at a profit.

It is a truism to say that the success of the railway has altogether exceeded the most sanguine expectations of its projectors; while the opinions of the great majority who condemned it as a regular money-sink have been quickly revolutionised.

Before April, 1903, most of the goods carried consisted of railway material. In $1903-4$ the total earnings of trains and steamers were $\ell_{1} 31,567$, and the year's balance sheet showed a deficit of more than $£ 60,000$. This deficit was decreased during 1904-5 to some $£_{3}$,000.

In $1905^{-6}$ the receipts were in excess of the expenditure by more than $£ 42,000$. At this figure they more or less remained till I9IO-I I when they were increased to more than $£ 73,800$. During this year the total tonnage carried increased to more than 77,000 , being an advance of more than 17,000 on the previous year, which was in itself a record.

This sudden advance, so far from dropping, looks like being increased at an almost more rapid rate during the present year.

Pleased though the average settler is at this sudden access of prosperity to the line, he is even more delighted with the concessions granted to him in the reduced export freights of certain staple crops, namely, maize, beans, and wheat.

During the early days of the railway, and of literature connected with the same, it would seem to have been inseparably connected with lions. Everyone knows that man-eaters held up the construction, terrorised the coolies, and enabled Colonel Patterson to write an intensely interesting book. It is a matter of common 
knowledge how a lion entered a first-class carriage and abstracted an inmate who was lying in wait to demolish the beast himself. The story reads like a romance, but is absolutely authentic. To me the greatest wonder is how the lion sprang through the small square window of the carriage as he did, bearing his prey. Again all recollect the various Babu stationmasters who have wired from time to time: "Lion on platform, me in ticket office, please wire instructions," or "please arrange." Lions are still a great feature and may occasionally be seen from the train. Indeed, when a boat train brings its load of tourists, shooters and settlers, it is usual for a crowd of towzled figures, male and female, to discuss at the early breakfast stop the herd of lions which they saw browsing under the trees at early dawn.

The older hand generally points out that it is a curious fact that, whereas it is the rule rather than the exception for the newcomer to see lots of lions on his first trip up, those who live in the country do not see one once in a hundred journeys. To this the tourist retorts with heat: "That is because you Colonials are sunk in sluggish slumber at lion time."

It is, of course, a matter for regret that the railway happened to hit off so few of the richest agricultural portions of the Protectorate. When the line was built there was no idea that there could ever be created a white colony in the heart of Africa. As far as one can judge, the idea was solely to connect Uganda, the fertility of which country had already been grasped, with the sea. Consequently, to take the shortest and eaisest route was the main object in view. In any case, it is certain that a very small proportion of the richest and most fertile districts is touched; which 
fact makes the pecuniary success of the undertaking all the more wonderful. To increase the traffic on the line, and, what is still more important, to open up and develop the resources of the interior, it has long been recognised that branch feeder lines are essential. Two such feeders are already in course of construction. The first, which is the work of a public company, is to run due west from Ulu to the great lake of Magadi, in order to make use of the wonderful soda deposit of which it is formed. The other, a Government work, runs from Nairobi towards Fort Hall, and opens up what should be one of the most prosperous of the settled areas. At present it is only projected as far as the Thika river, but it is obvious that this is but a stepping-stone, and that it will shortly be extended to Fort Hall and to the western slopes of Kenia with its magnificent forests, fertile soil, and teeming population, who have already many thousand acres under cultivation. The next feeder, in all probability, to be initiated will be either one to tap the Uasin Guishu plateau and all the fine country along the Nzoia river, or else through the rich Kavirondo district up to Mumias. The latter would benefit the native, and would pay from the start. The former would help to develop the Protectorate as a British colony, and would be a boon and eventually a most paying one to our fellowcountrymen.

Before taking leave of the subject, we will hurry the reader briefly over the line from Mombasa to the lake, guaranteeing him that he will wish often during the actual journey that it took as short a time to perform as to read about.

Arriving at Mombasa station, hot and probably rather fussed, we shall at once be faced with the 
problem of which class to travel. The first class carriages are very nice, clean, and empty. For the most part they are long and spacious with seats lengthways, sideways to the engine, and eminently suitable for slumber. But, alas! the price of the ticket is most exorbitant. The second class is an almost precisely similar compartment of a more advanced age, and into it one would at once spring were it not that the next similar compartment is crowded with about six Indians of the usual or baser sort, and that an inspection reveals to our olfactory senses that our compartment has recently had occupants of the same kind. I would like to urge on the management that certain compartments, first and second class, be reserved for Indians only. It is, I believe, recognised that the effluvia of hot Europeans is most offensive to the Asiatic, and in his interest I urge that it is most unfair that he should be subjected to them!

The difficulty of selection solved either by damning the expense or by squaring the guard (a more difficult matter, alas! than at home and only to be attained by an appeal to his patriotism or better feelings), we instruct our boys to arrange rugs and pillows to our liking and settle down. The train starts slap up to time at about I I a.m. and in a few minutes we are at the sea-port of Kilindini, where rows of trucks loaded with produce going out, or of machinery and implements coming in, testify to the agricultural activity of the Colony. Leaving Kilindini, we cross over a fine long bridge separating the island of Mombasa from the mainland. The first twenty miles or so lie through tropical country with plantations of rubber trees and cocoa-nuts on either side. At 


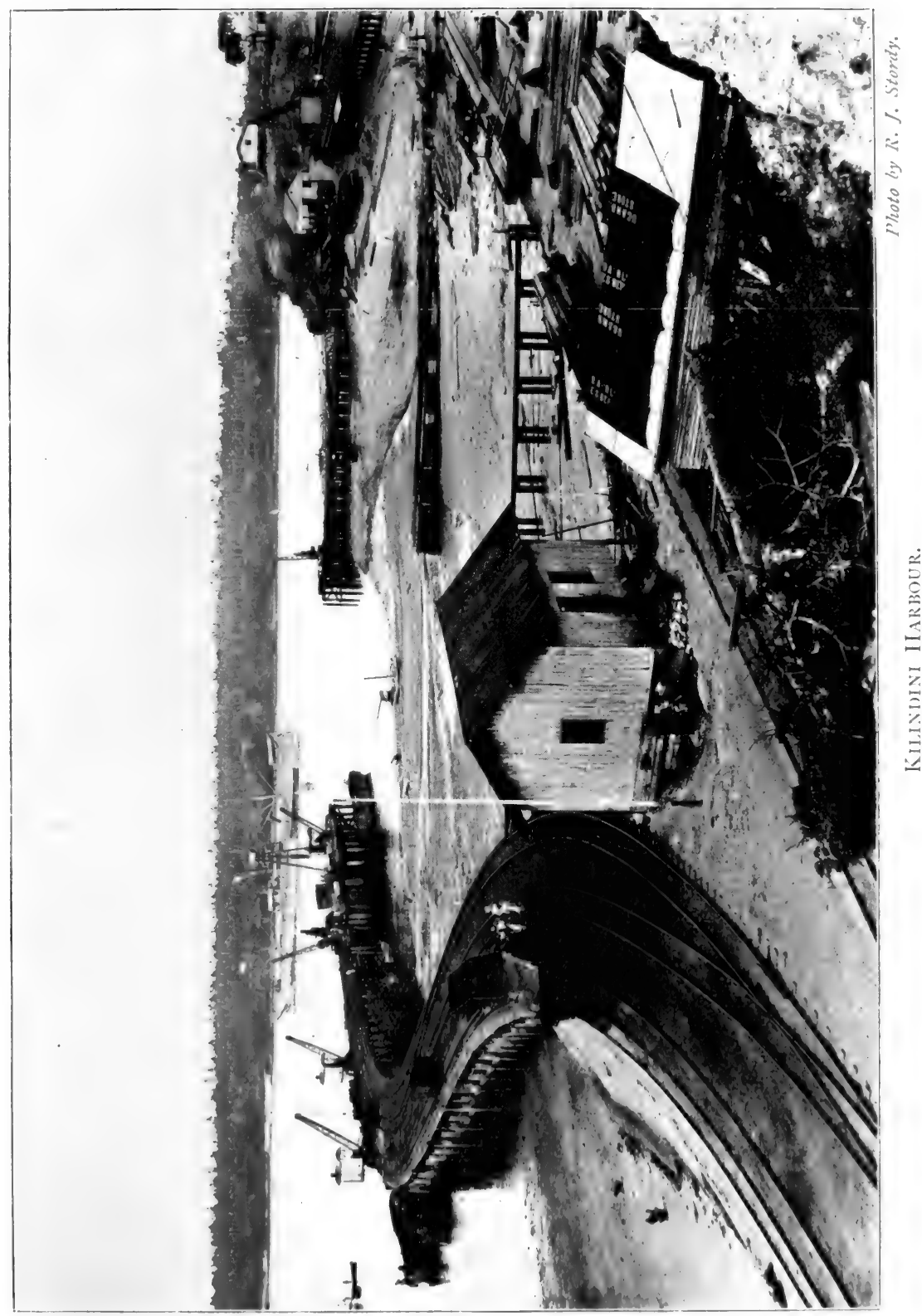



Changamwe or Mazeras, fruit is usually to be bought, and we will lay in a supply of mangoes, bananas, and oranges. A stop is made about 2 p.m. for luncheon, but on the whole it is better to have a well-stocked luncheon basket, in sampling the contents of which much time and provender may be profitably consumed. After twenty miles the dull uninteresting Taru desert is entered on, and affords a period admirably suited to slumber which we will indulge in up to Maungu. Here, as it is getting cool, we sit up and take notice, searching the bush country for a sight of lesser Kudu, oryx or vulturine guinea-fowl. At certain seasons most admirable sport is to be obtained here; which fact the railway officials, with considerable wisdom, kept to themselves as long as possible. About 7 o'clock the train reached Voi and dinner. The fare is clean and ample, if not wonderfully appetising. The consumption of much beer is to be recommended. As an aid to slumber it is not to be surpassed. There are several mosquitos at Voi, and as they are nearly all carriers of malaria, a dose of quinine will not come amiss. While at dinner, our boys will have made up our beds. If there are only two of us in the carriage all is well, but if three a little tact is needed to acquire the bed on the single side, leaving one's companions to sleep one over the other on the seat and the bunk that lets down above it from the roof. Make no mistake now in piling on rugs, as every hour will bring a lower temperature, and the bracing morning will be very different from the moist heat of yesterday. Two or three years ago, on waking up and glancing in a looking glass, one was faced with a brick-red face, and one's hair contained either a couple 
of ounces or half a pound of dust according to one's sex. In the last two years, however, the whole length of the line has been ballasted with granite, and the passenger can contemplate his own visage with his customary equanimity. Dawn finds us at Simba or Sultan Hamoud, and from there to Nairobi we pass through a natural zoological garden. We may see lion and rhinoceros ; we are sure of giraffe, zebra, wildebeeste, and according to the season, thousands or tens of thousands of antelope. Our train will be treated with supreme contempt. The game are certainly no more shy of us than cattle or horses in a paddock; though were we on foot we should find it extremely difficult to get within a quarter of a mile of any but the youngest and least sophisticated. Tea and eggs are provided at Ulu; with regard to the latter, I may have been unfortunate, but to my mina they are to be regarded with caution; and the older traveller usually makes his own provision for this meal. Crossing the stony Athi and the Athi, from the former of which more lions have been killed than from any similar spot in Africa, we soon get a view of Nairobi with its red roofs interspersed with wattle and gum trees. Neat homesteads spring into view, and cattle and wire fences take the place of the primæval veldt. At about I 1.20 we glide into the fine stone built station and draw up along its crowded platform. In addition to those who have come to meet friends or to board the train, there is here, as in South Africa, a considerable crowd who seem to have nothing better to do than to meet each train, drink with acquaintances, and pass the latest scandals. There is a good interval allowed here for luncheon and soon after noon we start North again ; first passing through the Kikuyu native 
Reserve, and then ascending to the very prosperous Limoru district. Here we have essentially the home of small homesteads. Mixed farms, fruit farms, coffee and wattle plantations are intermixed. All do well and as the soil and rainfall are good and the climate glorious, land here is as valuable as any in the Protectorate, being at the average price of from two to four pounds an acre.

After a few miles there is a steep and very beautiful descent through the forests of the Kikuyu escarpment into the great Rift valley, which lies below us in a glorious vista; and in another hour we are in the sheep country. The change comes incredibly quick, for we are now in a dry, warm climate, passing through undulating plains and hills of short, sweet pasture. Homesteads are nestling under hills and great flocks of sheep are grazing far and wide. Tea is at Naivasha station where there is a pretty little town on the lake of that name famous for its ducks and hippopotamus, and erstwhile for the thousands of Grant's gazelle which browsed along its shores and whose place has now to a great extent been usurped by the more profitable sheep. We shall get some splendid English eggs here, about which we need have no suspicions whatever. After tea we shall be passing through the same type of country for two or three hours, while the sun sinks and the wood sparks from the furnace begin to glow. Wood fuel, cut and supplied along the line itself, is now used exclusively. It is likely, however, that, with the traffic increasing daily, a change will be made. Coal or oil may be used as far as Nairobi. Beyond, wood will probably always be used. Not only is there a good natural supply, but the wattle industry will have an ever-increasing quantity to 
dispose of. Wattle timber is excellent fuel, but very hot, and will probably necessitate an increased size of fuel box; but the wattle industry is likely to be such an important one to the Protectorate that to a Stateowned line this is a minor detail.

Nakuru provides us with our dinner, and an excellent one it is; the hotel here being without doubt the best in the country. This town is the centre of the stock-raising district and the scene of the annual agricultural show; it is likely to be a place of some considerable importance.

Night is now upon us, and we shall accordingly pass deep in slumber through perhaps the most interesting as well as almost the richest portions of the line. First comes Njoro with its wheat-fields, some 5,000 acres of which are already under crop, its wattle plantations, its saw-mills, and its pigs. Then we shall run through the glorious cedars of the Mau forests, the haunt of buffalo and elephant and of the mysterious bongo and the giant forest hog. After this we come out into the rolling downs, splendid pasturage, and forest glades of Molo. Once over Mau Summit, 8,300 feet high, we begin to drop towards the lake, passing into forest land again. At Londiani a splendid new and metalled road branches off to the Uasin Guishu plateau, and this place is likely to be one of the most important centres on the line. Not only is it extremely beautiful and healthy enough to be a sanatorium, but the soil, especially suitable for wattle, is second to none. Already an extremely comfortable hotel and other buildings mark its advance. Lumbwa is another centre of a farming community growing wheat and wattle and declaring 
that their locality is the pick of the Protectorate. From Lumbwa we descend into the sub-tropical area bordering Lake Victoria, an area unhealthy; perhaps, but intensely rich; and shall eat a well-earned breakfast at Port Florence, our assumed destination. 


\section{CHAPTER XXI}

THE MILITARY AND POLICE FORCES IN THE PROTECTORATE

For several reasons the military and police forces of the Protectorate are both of interest and importance to the settler. Firstly, he is almost certain to require from them either passive or active assistance. Secondly, he will certainly come into contact, receive and return hospitality, with the exceedingly hospitable and popular white officers connected therewith. And, thirdly, he will, indirectly at present, have to pay for their upkeep.

The military forces of the Protectorate consist of one battalion and two additional companies of the King's African Rifles, the police numbering in all about 1,470 , the volunteers, and legion of frontiersmen. Of these the police are a necessity; the white volunteers, as elsewhere, an obvious desirability; while about the King's African Rifles blazes the fire of debate.

We will start with the police and deal only with the last two years as being essential to the present and future. In 1909-10 the total strength of the force was $\mathrm{I}, 819$; and in I9IO-II this number was reduced to I,470. The reason of this considerable reduction lay in the withdrawal of considerable bodies of men who were employed on garrison duty. These garrisons 

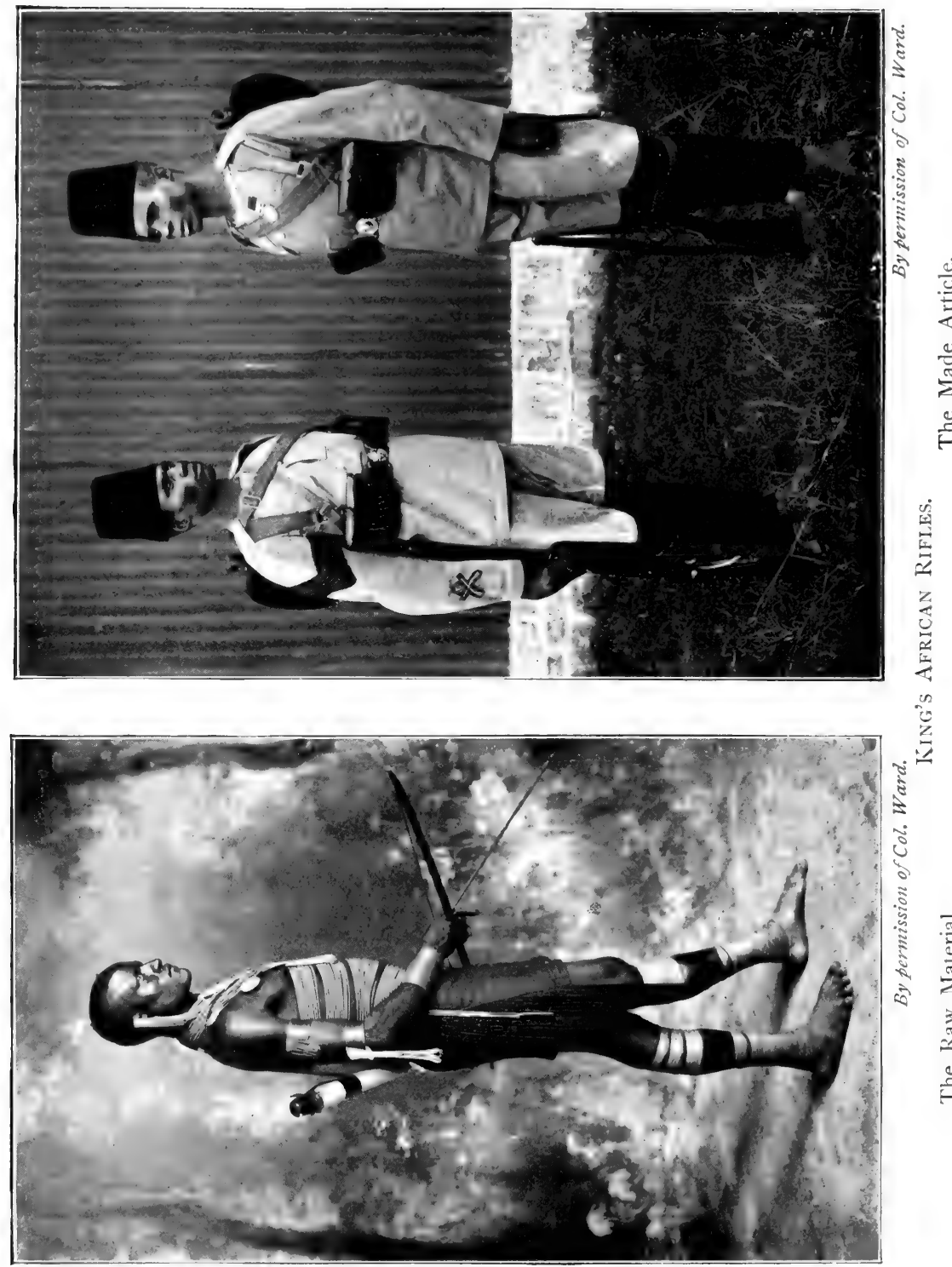

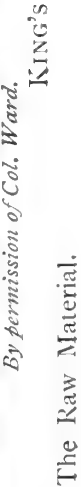


were replaced by the King's African Rifles, who had previously been mainly held in reserve at various centres and used as a striking force.

The discipline of the force leaves little to be desired. A certain amount of dissatisfaction with regard to it certainly exists, but probably this is more comparative than real. The standard maintained by the King's African Rifles is so high that any other body must almost inevitably suffer if judged by the same standard. This superiority of the soldiery is to be accounted for by the high traditions connected with the regiment, the slightly higher scale of pay accorded to the men, and by the splendid type of officer which the prospect of good pay and fine sport attracts. The amount of petty crimes in the police force has undoubtedly been in the past greater than it should have been ; it is, however, steadily diminishing and there can be little doubt that under the sound administration to which the police are now subject it will not be long before these crimes show a satisfactory reduction.

In 1909-10 some 2,400 persons were arrested or summoned, and about I,900 were convicted or permitted to compound their offences. In I9IO-I I the proportion was 5,733 and 4,536 . This is doubtless a fairly satisfactory proportion, but in dealing with natives who have very little regard for truth and very little fear of prison it is unsafe to draw too many conclusions. The police have naturally to employ native detectives, a proportion of whom, at all events, have a personal knowledge of the inside of a cell. There is reason to fear that in their desire to get convictions these gentry are not actuated by quite the same sense of justice as, say, the London police. Possibly I may be slightly prejudiced through having suffered on one occasion 
through the administrations of a native detective. Having been the victim of a petty theft, I duly reported the occurrence. Some days later the head house boy approached me in a state of considerable excitement and reported that there was a detective concealed in a clump of papyrus which stood in the garden next the house. Looking out of the window, I observed a red tam-o'-shanter which bobbed up and down in the centre of the clump, in which position I allowed it to remain. After about two hours the wearer of the hat emerged and proceeded to arrest and handcuff the whole of the coloured portion of the household. Though certainly the accomplishment of this feat by one savage clad mainly in a red tam-o'-shanter and a pair of button boots was in itself admirable, the clues found in the papyrus bed seemed insufficient to cause the arrest of the whole of our staff and the subsequent demoralisation of the midday meal. There is no doubt that this was an extreme case of misdirected zeal.

In 1909-10 the estimated value of stolen property reported was $£ 4,758$, of which property to the value of $\mathscr{L}^{\mathrm{I}, 988}$ was recovered. In 1910-I I the figures were $\ell_{4}, 445$ and $\ell_{1}, 34 \mathrm{I}, \quad$ By no process of imagination can these figures be regarded as satisfactory. Practically all stolen property goes into the hands of Indian "fences," as the police are well aware. These receivers of stolen property are, however, so clever as almost to defy detection; a fact that must be at least as galling to the police as to those who suffer by their depredations.

The total cost of the police fo I 909 was $£ 46,273$, which was reduced in 1910 to $£_{38,923}$.

The prisons in the Protectorate are in a thoroughly satisfactory condition, and prisoners are so well looked 
after that certain irresponsible satirists divide the native population into two classes : those in prison and those who want to be. There are two first class prisons, one at Nairobi and one at Mombasa, into which all long-service prisoners are removed. Here they are taught various industries, such as chairmaking, basket-work, carpentering, etc. ; indeed up to I9I I jail was the only place in which a native could get any technical education. The unfortunate result of this was that a native who had any knowledge of a useful trade was, ipso facto, branded as a criminal. The short service prisoners at the various district lock-ups are very rightly made to do their share of work and are employed in such tasks as road-making, bush-clearing, gardening and generally in keeping clean and tidy the various Government Stations.

Taken as a whole, it cannot be gainsaid that the police force is a fine one and splendidly administered. Those who suffer through various crimes and feel that they do not get sufficient police protection, which is of course more especially the case with regard to stock thefts, are apt to minimise the huge difficulties with which this force is confronted. Rather is it a cause of admiration that they effect as much as they do, and a source of gratification that the grip of law and order over the country increases year by year.

The King's African Rifles merit most attention, not only on account of their splendid record and personnel, but, as I have said, through the questions of expense and distribution to which they give rise.

The ordinary military expenditure in 1908 was $£ 45,387$; in 1909, £46,639; and in 1910, $£_{40,398 .}$ These sums represent, not only a very large figure per head of the military force, but a very large proportion 
of the grant-in-aid received by the Protectorate. This grant-in-aid the majority of settlers in the country would like to reduce to a vanishing point at the earliest possible opportunity. The reason of this sentiment is twofold : the feeling that it is unfair that the taxpayers in England should be mulcted on their behalf a moment longer than necessary, and the more selfish consideration that when they no longer exist on charity the white population are likely to get a more just appreciation from the Colonial Office of their legitimate demands. ${ }^{1}$ Before, however, touching on the question of disbandment, reduction, or redistribution, it may be as well to append a short history of the $3^{\text {rd }}$ or East African Battalion of the King's African Rifles, which form the force with which we are primarily interested.

In July, I895, the Imperial British East Africa Company ceased to exist and the territory ruled over by this Corporation together with its then existing armed forces were taken over by the Imperial Government.

In $1896-7$ the reorganisation of the British East Africa Company's old forces into the East African Rifles was carried out.

In 1899 the establishment of the battalion was raised to nineteen British officers and eight companies.

In I902, the East African Rifles became the 3rd Battalion King's African Rifles, the headquarters were fixed at Nairobi, and the present lines erected.

In 1904, the strength of the battalion was raised to ten companies by the transfer of two companies from Uganda.

1 The grant in aid ceased in the spring of the present year, which fact caused the most widespread satisfaction throughout the Protectorate.-C. 
In 1905, owing to the arrival of a reserve battalion, the Ist King's African Rifles, the strength of the

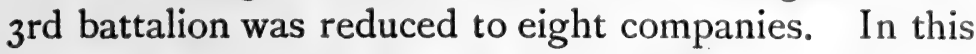
year the battalion was re-armed with 303 Martini Enfield rifles.

In 1907 a further reduction of two companies was effected.

In I9 I the strength of the battalion was raised by the addition of one company.

In 1912 the strength of the battalion is as follows :-

24 British officers.

I Warrant officer.

7 Companies of 125 rank and file.

These are distributed :-
At Nairobi
... 2 companies,
On the Northern Frontier I company,
In Jubaland $\quad \cdots \quad \ldots 4$ companies,

while there are in addition two companies of the first battalion stationed in the Protectorate.

With regard to the Personnel. - The Soudanese have always been looked upon as the mainstay of the battalion, but it becomes every year more difficult to keep them up to strength. The fighting qualities of this race are well known: they form without doubt the finest fighting material in Africa. During times of peace they are somewhat apt to give trouble, to which their womenkind are absolutely certain to add. The latter are of very powerful physique and of villainous temper, and it speaks wonders for the Soudanese men that they are able to impose on their womenkind the amount of subjection that they do. The male Soudanese, though all wire and whipcord, are usually of light build. 
In addition, the following races have been enlisted : Swahili, Masai, Nandi, and Abyssinians. Of these probably the Swahilis are the best. The Abyssinians are intelligent, brave, and when properly taught form good marksmen; although in their own country the usual standard of shooting is execrable. They have, however, a deep-rooted dislike to discipline, and an almost ineradicable contempt for Europeans, which qualities detract from the value of their good points. The Nandi form fair material, but the Masai are disappointing.

The conditions of service are six years, with the privilege of re-engagement for periods of three years. They are liable to serve anywhere in the world.

The rates of pay are:-

\section{Soudanese.}

Colour sergeants...40 rupees per month

Sergeants $\quad \ldots \quad \ldots 34$

Corporals $\quad \ldots \quad \ldots 30$

Lance-corporals ...28

Privates $\quad \ldots \quad \ldots 26$
Local Tribes.

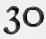

28

24

20

I 6

Reverting again to the retention or otherwise of the regiment, those who are anxious to reduce the large yearly expenditure adduce the following arguments. Firstly, that there is no necessity for a garrison in Nairobi. That the Masai and Kikuyu are now thoroughly peaceable and subdued, and that, moreover, if they did make a sudden and unprovoked attack the small body of troops available would be of no material use. That the troops stationed in the out-districts, and more especially on the northern frontier, are enormously expensive and of no present or prospective use to the Protectorate proper, and that 
the cost of the same, if it be borne at all, should fall on the shoulders of the home Government which enforces their retention.

To these arguments those who are anxious to retain the troops reply: With regard to the safety of Nairobi and of the close white settlement around it, the great probability is that there is no need for alarm. But on this point probability is not enough. Where the safety of white women and children is concerned, not to mention the interests of the whole population, black and white, certainty, humanly speaking, is required. Neither the Kikuyu nor the Masai have ever been subdued by force of arms, and the latter at all events hold Europeans in detestation, if not contempt. It is admitted that, were the native population to make a sudden and treacherous attack on the peaceful inhabitants of the town, the garrison would be powerless to check them. But it is not a defensive force that can anywhere prevent attacks on an undefended town. Such attacks are prevented solely by the fear of reprisal. This fear of reprisal and punishment is kept alive by the sight of a military force which is seen daily and is known to be prepared to inflict instant punishment. Further, that though such a garrison is a certain expense, a considerable proportion of that expense is re-spent in the town, the attractions of which are also incidentally much increased.

I must confess that the latter set of arguments have with me the greater weight. Two companies of native infantry appear to constitute a force dangerously small to guarantee the safety of the white population. Many people would much like to see the addition of a battery of screw guns. It is probable that those of an obsolete pattern could be easily obtained from India. One 
tribe, the Wa-Kamba, at all events, are absolutely precocious at anything connected with machinery; and there is no doubt that the sight of a bursting shell has a wonderfully deterrent influence on the bellicose intentions of the savage. It may be, and is, argued that it would effect a saving if the defence of the country were entrusted solely to an augmented force of police. Perhaps there might be a saving in money, but there are many who think that police work should be entrusted to police, and military or punitive operations to soldiers. Certainly, excellent as the police are in their own sphere, they have much leeway to make up before they can compare in efficiency from a military point of view with the King's African Rifles. Before disbanding or curtailing further the small but highly efficient force that we now possess, it is to be hoped that those who are responsible will take down the map and mark well the various people who form our neighbours.

The question of the troops on the Northern or Abyssinian boundary gives rise to a different class of question. On this boundary we have one company of the King's African Rifles. They are scattered over a series of posts into which they are dug and fortified. Owing to the difficulties of transport across the desert country which separates the frontier from the habitable Highlands, they are admittedly enormously expensive.

Those settlers who are averse to what is called the Frontier policy argue that a very large expense is incurred. That no gain does or is likely to accrue to the Protectorate from the maintenance of these isolated forts. That, on the contrary, the scattering of these isolated baits is liable at any moment to involve us in an expensive war or the sacrifice of what little 
prestige we still maintain. That when the Abyssinian boundary was delineated it was so drawn with a view to interposing the desert as a buffer between ourselves and a warlike and predatory race. That these posts are most unhealthy and disagreeable, and that the loss we suffer through their retention is for this reason not one of money alone.

These arguments are without question true in fact, but the advocates of the wider policy produce as a counter the argument that when we as an Empire undertook the administration of the Protectorate we undertook the liabilities attaching to the worst in addition to the benefits attaching to the best portions of that Protectorate. It is therefore our bounden duty to give adequate protection to even the poorest and meanest tribes which inhabit its furthest boundaries.

As to the weakness or soundness of these conflicting arguments each man must judge for himself. It may, however, be pointed out that the present policy is unlikely to meet with favour with either side, since though the expense is great the garrisons are too meagre to afford protection to our subject races. Moreover, the instructions of those garrisons are, or have been, to suffer any indignity sooner than risk embroiling themselves with our neighbours across the frontier.

It is with the volunteer movement that it is hoped to replace, as time goes on, our professional soldiers. Already we are possessed of a good proportion of keen and genuine volunteers-to take no account of those who have joined the corps for the sake of acquiring a rifle and cartridges wherewithal to replenish the larder. Moreover, there is a stout band of the Legion of Frontiersmen, to say nothing of the Boy Scouts. 
For the present, however, distances are too great and communications too difficult for the volunteer movement to be very general. Also the large proportion of the population are too busy earning a living and developing the resources of their country to have time to acquire even the minimum amount of discipline. 


\section{CHAPTER XXII}

\section{LOCAL POLITICS}

Every Colony in the making, and until such time as it is in a position to manage its internal affairs, passes through periods of political unrest; and such periods do not tend to get less frequent and intense as the country more nearly approaches the time when it may fitly be trusted with such management. To this rule British East Africa is no exception. When the first driblets of pioneer colonists appeared and took root, I think that it may be fairly admitted, without any disparagement to a fine body of men, that the officials as a class resented their presence. This fact rendered the formation of a political situation easy. It was simply a case of a struggle for existence by the colonists and of antagonism to the official element. Elsewhere I have shown how this animosity arose, flourished, and finally died away, its end being almost synchronous with the advent of the present Governor, Sir Percy Girouard. ${ }^{1}$ Since the ending of this first phase politics have taken a much more complex turn and, on the whole, an altogether more satisfactory one. Although on various different points there has and always will be very strong feeling shown, for which, I

1 Sir Percy Girouard resigned his office, to the great regret of the majority of Colonists, July 16th, 1912. 
believe, the strong air is in a great measure responsible, it only arises from different points of view as to what will be for the ultimate good of the country. As is natural, the colonists are anxious to get the control of their internal affairs at as early a date as possible; as to their fitness for such control, they are probably rather prematurely sanguine. As is equally natural, the Government, more especially in Downing Street, are anxious to hold the reins as long as possible. The position of Dictator must naturally be more easy and pleasant to hold than that of salaried servant. The view that they take, therefore, as to the fitness of the inhabitants with respect to each advanced step towards self-government is probably as over-gloomy as that of the colonists is over-sanguine.

The principal points of contention which arise on these lines are the present position of the non-official members of the Legislative Council, the Education and Land Boards, and the desire among the colonists that all such posts should be elective, the question of the system of land tenure, and that of the Asiatic population. Then, again, there are arising a series of questions all leading up to what is certain to be the first cleavage in internal politics, i.e., the town population against the farmers.

At the present day we have under the Governor, who in his turn is of course under, and very much under, the Colonial Office, three advisory bodies. They are the Legislative Council, the Land Board, and the Education Board. The last two have their special functions and really exist to lighten the work of the first named, and as the same remarks apply to the composition of each, it is only necessary to deal here with the first. 


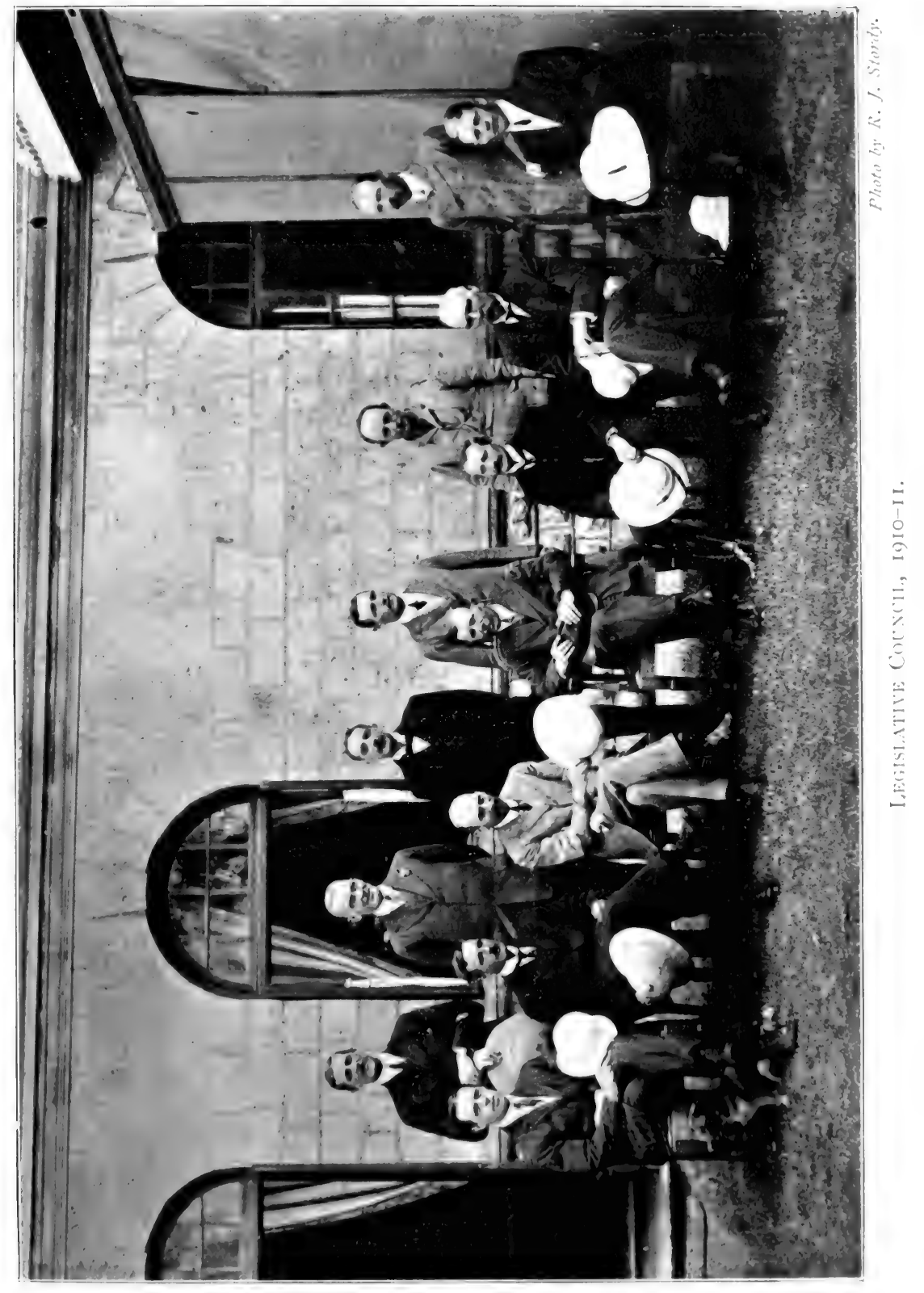



The Legislative Council consists of a majority of official members and a minority of non-official members. The former are chosen by the Governor, and though a certain latitude is given in speech, are only allowed except in the rarest instances to give other than a party vote. The latter were also at first actually, and are now technically, nominated by the Governor, but as a matter of fact they have for some time past been held to represent certain districts or industries and in their nomination the wishes of such interests are very rightly considered. Indeed, for the Land and Education Board various local bodies have been asked to select names.

There is at the present time a growing desire that posts on all these bodies should be entirely elective. I must confess to not sharing this desire, for the present, and until the country has shown further development. Communications are so difficult, and work is being pushed forward so fast on all sides, that the best men would never have the time to undertake contested elections and political campaigns, and there would be a tendency for responsible positions to get into the hands of political agitators. A year or two hence the time for such a change may be ripe. It is, however, with regard to the functions of the non-official members that the principal ground for controversy exists. The view at present held by the Government is that they exist merely for the purpose of helping by the giving of advice when asked ; the view of the members themselves is that they represent to some extent the people and that on their behalf they are not only entitled but bound to criticise and if need be find fault. The first view is probably technically correct, but surely the latter is more logical. 
I submit that the position of the non-official members corresponds with that of the Opposition in Parliament - though here it is a permanent opposition. Even that opposition is, I imagine, really in existence ostensibly for the government of the Empire; but though they are presumably ready to give advice when called on, yet naturally their help is given almost entirely by criticism of, or direct attack on, faulty or unnecessary legislation. I cannot believe that this objection to legitimate criticism is likely to continue long.

The bodies that have in the past and do at the present day represent the purely settler element are many and various. The most notable one in the past, and certainly the body that has done more spade-work than any other, has been undoubtedly the Colonists' Association. This body fought an uphill fight in the settlers' interests during what may be termed their struggle for existence. It was representative of the whole body of settlers, who in those days of course occupied a much smaller tract of country than they do at present. Under the presidency of Lord Delamere and of Mr. Grogan, it placed the settlers' points of view before the Government again and again, and though in the course of events it made a few mistakes, the work it did for the country can never be forgotten. When the recognition of the settler was complete the need for this body diminished. The area under white occupation was growing, the population increasing, and new interests were springing up almost daily. Each of these interests began forming its own association. Perhaps through no fault of its own the Colonists' Association lost touch with these outside bodies, and indeed became somewhat unpopular. The newer and more local bodies resented its assumption of authority, 
and accused the parent body of using its old name for the furtherance of the interests and ambitions of a small clique. By I9 Io the old Colonists' Association could no longer be said to be in any way representative of the farmer's interests, and Lord Delamere and others determined to form another body that should be in a position to speak for the whole country. This body was formed and constituted what is now known as the Convention of Associations, or, more shortly, the Convention. This association, which as far as possible represents every locality and interest in the Protectorate connected with white colonisation, meets, except in urgent circumstances, but twice a year. It is attended by Delegates selected by every Association of any sort whatever. Indeed, the ambition of every class and sect to send such a Delegate was carried at first almost to ludicrous lengths, culminating in a notice, no doubt bogus, in the local paper to something like the following effect :-

The Rat Killers' Association Meets Next WEDNESDAY

Agenda : (I) To kill the rats in my back garden.

(2) To select Delegates for the Convention.

Such Delegates are instructed by their Associations to introduce various matters for consideration. The institution as a whole is an attempt to form a local Parliament on as broad lines as the exigencies of the situation permit. Among various bodies which send Delegates are-The Colonists' Association, the Land-holders' Association, the Pastoralists, the Coffee-planters, Ulu, Limoru, Uasin Guishu, Ndarugu, Kyamba, Lumbwa, etc. 
Topics of local and general interest are discussed. Thus the Uasin Guishu settlers who live very far from the Railway and the Capital might bring through their Delegates a motion advocating increased and improved means of communication. The Pastoralists might have another to discuss Stock thefts. The Colonists' Association will probably bring forward matters of more general interest such as a demand for an Agent-General in London to further the interests of the Colony. The Land-holders' Association are pledged only to bring forward matters connected with land and land tenure. While the Ulu settlers whose district borders the Game Reserve may be confidently expected to bring forward some resolution dealing with the damage which they suffer through the depredations of its inhabitants.

Such matters will be thoroughly discussed and a very fair idea of the popular opinion on them throughout the country gained. The various motions are submitted to the Government, to whom they should be of considerable service.

Yet another body has arisen within the last two years, which bids fair to have a considerable influence on the future of the Colony. This is the Landowners' Association. Its inception is due to the growing and inevitable cleavage between the farmers on the one hand and the townsfolk on the other, and also to the great dissatisfaction to the general policy of land administration which is mentioned elsewhere. Its object is to support the interests of agriculture and of all classes of owners and occupiers of land. It has a large membership and considerable funds. It may be admitted without cavil that the future prosperity of the country is absolutely bound up in the prosperity of its agriculture. Farmers as a class are prohibited by the 
nature of their work and in many cases by lack of communication from direct and regular participation in politics. They found, as we find in England, that this inability is taken advantage of by politicians, and their interests were being subordinated to and made the sport of party politics. They therefore formed this association, which is pledged to have no part or share in such politics, but simply exists to protect the interests of agriculture and agriculturists. Possibly we could do worse than have such an Association at home.

The next step towards self-government will undoubtedly be the division of the country into constituencies, which will each elect a member to form the opposition on the Legislative Council. Such a transition stage on the road to complete self-Government is an extremely disagreeable one both for the Government and for the governed. If this stage came now, it would, I fear, be bound to continue for a good many years. My impression is that the longer the step is delayed the shorter will be this tiresome species of interregnum and the quicker will come the ultimate development and complete self-government of the country. 


\section{CHAPTER XXIII}

\section{EDUCATION}

Education has been and is a source of very considerable perplexity to those responsible for it. It may be presumed that there is nothing very peculiar about this fact. Part of the price that the pioneers in a white colony in process of formation have to pay, lies in the hard choice of either parting from their children or in seeing them grow up but imperfectly educated. In British East Africa the problem is, however, unusually complicated owing to the variety of Residents and their several claims. There are the innumerable native tribes, all with divers tongues. They certainly show no special desire for education, but we have a duty towards them, and possibly that duty includes the putting before them of at least the chance of betterment. Then we have the Indians, who clamour loudly for teaching, and, further, for teaching in the vernacular. For anything which he can get for nothing the Indian is always ready. Then, again, we have the Boer, who firmly and insistently demands to be taught in Dutch. Finally, there is the white Colonist, who wants and must have the best facilities for education which the finances of the Protectorate can afford. The conflicting claims of these various classes is bad enough, 
but it is rendered even more so by the overlapping of two sections and the further and increasingly difficult situation afforded by the half-caste and Eurasian.

For many years the education of the country was entirely in the hands of the Missions, and no one can exaggerate the good work done by them. The first attempt to provide any State-aided education for European children was the Railway School in Nairobi, which school offered for some years in its turn almost the only chance a settler had of educating his family. At the present time the Government have seriously grappled with the problem, and every year sees an improvement in the facilities offered. The Protectorate has now a Director of Education, Mr. R. J. Orr, from whose energy and concentration of purpose much is expected. Under him there is the Board of Education and further on in the chain the various headmasters and their staff.

A sum of $£ 7,000$ a year is at present set aside for educational purposes. This sum forms the basis for a good deal of self-praise from our Government, and is said to compare favourably with any similar grant in any similar colony. For myself I would rather regard it in connection with the work to be done and the various classes to be considered, and if one does so no man can say that it is excessive. This sum covers buildings, repairs, and salaries, besides all incidental expenditure connected with the education of the children of 3,500 Europeans, of 20,000 Indians, and two millions of natives. I cannot see that it is unduly large. Compare it with the vote on military expenditure; or on the public works expenditure. It will stand the comparison. It might reasonably be thought that it would not be an egregious demand to ask that 
this sum should be the minimum allocated solely for the education of the children of white settlers.

This $£ 7$,000 having been allotted for educational purposes, certain portions are subdivided and earmarked for certain definite ends; e.g., for buildings, for the education of the sons of chiefs, for technical education, etc. Certain minor details connected with this expenditure are left to the Education Board. This Board is a rather farcical body, similar in composition to the Land Board. The majority on the Board are official and have to vote according to order, and should, through ignorance of the wishes of their superiors, any instruction or decision get through which is not in accordance with those wishes, it is countermanded without comment or discussion. It may be said, and I fully believe correctly, that the Government are usually better informed and more likely to be in the right than the nominated Board. It is, however, rather a source of wonder that civilians can be found to serve in a situation so thankless and so ignominious.

Amongst the various purposes for which the money is allocated come the European Board School in its various branches, the schools for Indians and Eurasians, and also native education, which includes education for the sons of chiefs and technical education. The High School at Nairobi, under the management of Mr. Turner, formerly headmaster of the Uganda Railway School, is, when everything is taken into consideration, a miracle of efficiency. This efficiency it owes perhaps mainly to Mr. Turner, the headmaster. The buildings are formed by the conversion of the old police barracks, which naturally were not especially suited for the purpose. However, the expenditure of time, thought, and a good deal of money has done 


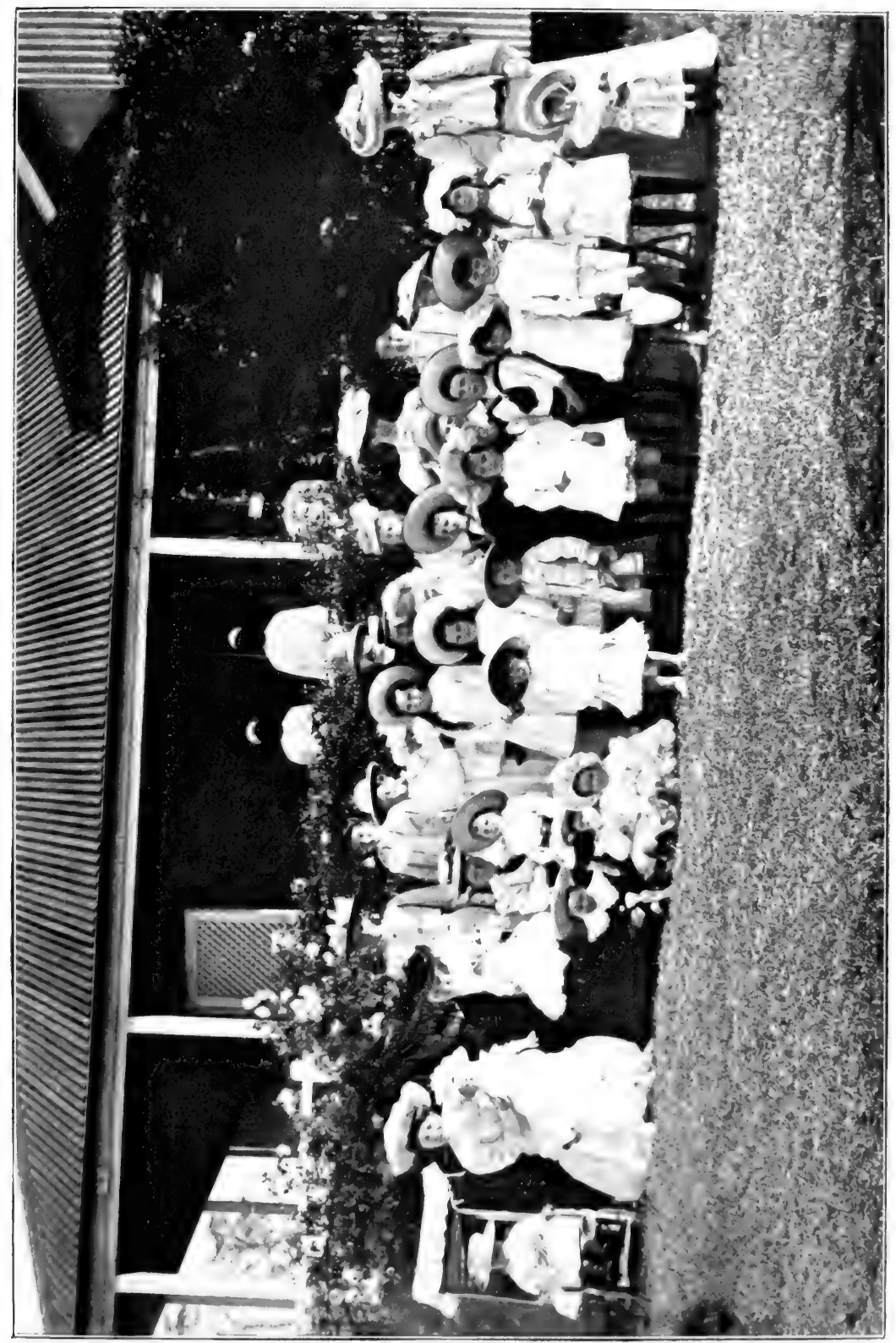



wonders. The class-rooms are light and airy, and sanitary arrangements of all kinds are as perfect as the situation and nature of the buildings will allow. It is to be regretted that they consist almost entirely of wood and iron, and consequently are apt to get very hot at mid-day. Important as it is to adults in the tropics to live in stone or wooden houses, it is doubly so in the case of children. We may feel pretty certain that as funds permit the alteration will gradually be made. The elementary education is in every way excellent, and at the present day more is hardly to be expected. Boarders are accepted, as far as space permits, at a very moderate fee. The food is good and plentiful, and the dormitories all that could be desired. Games and recreations are looked after, and the boys have a football team which could hold its own with most private schools in England. The children are periodically weighed, and judging by their appearance are a fairly substantial lot. In a tropical climate both sexes mature earlier than in England. This fact leads to the necessity of an early age limit being rigorously adhered to, and forms a further difficulty with regard to higher education. The age limit for boys is between twelve and thirteen, but in the case of backward pupils a separate boarding house accommodates them up to the age of fourteen.

The problem provided by Eurasians grows increasingly hard, and the difficulties are such as can hardly be adequately realised in England. There the colour question does not occur, and the great barrier between black and white does not exist. Coloured gentlemen go to our public schools and into our Universities, they play games with us and share our social intercourse. Rajahs' sons are courted by 
all and are even allowed freely to patronise our women who, hypnotised partly by their personal attractions, and partly by their jewels, submit with a wonderfully good grace. Sometimes even the marriage ceremony is entered on, though seldom without subsequent repentance as far as one may judge. East of Suez, as all the world knows, between the two colours a great gulf is fixed. There may be and very often is mutual admiration between high types of each race. Occasionally there is friendship; more there can never be. Whether this barrier be a good thing or a bad thing is capable of argument from every point of view, but one thing can hardly be denied and that is that without it there could have been no Empire of India. The stability of this Empire is threatened, ever so slightly, not by the pin-pricks of such men as Keir Hardie and the insignificant class of white and coloured idiots who listen to his babbling, but by the ever-growing numbers of Eurasians and the difficulties that they present. One cannot but feel that Nature made one of her few mistakes when she rendered fertile the cross between black and white, and so gave rise to all the trouble that this fertility has produced.

In the Protectorate we are faced with one slight ramification of the trouble in our schools. Europeans refuse to send their children to any school where they may associate with black or Eurasian children. On the other hand, the slightest touch of white blood causes the Eurasian to hold an intense scorn for the pure Indian. At present an attempt is made to face the problem by sending all children of Eurasian extraction to the Indian School, or rather by refusing them admission to the European school. This 
decision causes satisfaction to the European, intense dissatisfaction to the Eurasian, and an infinity of the most disagreeable work to the Education Board. It has been the onerous duty of the latter to judge of the pedigree of the various candidates for admission to the European school. As far as I know, the task has so far been carried out without bloodshed. The great hardship lies in the fact that refusal of admission brands a child for life, however white his skin. Many children of mixed origin are perfectly white, but may have a brother or sister very much the reverse. I recall an occasion when a furious and tearful lady brought three children to certain members of the Board with the indignant query, "How can you deny entry to your school of white angels like these?" There was, however, left behind another angel of distinctly murky appearance, or, to speak plainly, as black as one's hat.

A fair, reasonable, and satisfactory solution is hard, if not impossible to find. Many at home may say "solve the difficulty by sending them all to one school." They would not, however, find one per cent. of Europeans in Africa who would for one moment agree with them. Those Eurasians who have the chance might be well advised to stay west of Suez!

The schools for Indians and Eurasians are equally good of their kind. The younger children are taught in the vernacular, and though a good many people object to this practice with some show of reason, it undoubtedly not only saves time, but is almost essential with our present limited resources.

The education of the Dutch colony on the Uasin Guishu plateau has caused considerable difficulty. This colony are as a class miserably poor and ignorant, nor 
are they distinguished for their loyalty. There are those who contend that when they, or rather I should say when the majority of them, left South Africa and settled in the Protectorate the gain was South Africa's and the loss was our Protectorate's. Be that as it may, they are certainly too poor to pay the lowest boarding fees, nor will they consent to be taught otherwise than in the Taal. The general demand has been for a series of wandering Dutch teachers who will go round and expound in various districts. There is, however, also a small stationary school at the Government centre.

Again, there are some who say that they cannot see why British gold should be spent in teaching Dutch rebels in a foreign tongue. There are others who say that to educate the beast will raise his status, and that an educated Boer is more loyal and of more use than an uneducated one. Further, that to attain that object it is best and cheapest to start his education in the Taal. Perchance there is an element of truth in both arguments.

In I9I I it was thought desirable to impose a veneer of education on the sons of chiefs ; whereby it was felt that they would be bound the closer to us and would also acquire an added authority among the tribes. For this purpose a sum of $£ 800$ was voted. The method of their education, however, did, and still does, present considerable difficulty. The original idea, as promulgated by the Government, was that the sum should be subdivided in the nature of a bonus or grant among the Missions of various denominations, who should then grab as many sons of chiefs and headmen as evaded the clutches of their neighbouring rivals. It was pointed out by opponents of this scheme, firstly, that already the Missions were educating the son of every 
chief whom they could induce to consent to that process, and that therefore the cash bonus, though no doubt acceptable, would in reality effect no educational purpose. Secondly, that unless the Missions would consent not to proselytise the said youths, which consent they indignantly and not unnaturally refused, it would hardly lead to peace to impose with the aid of public money a denominational conflict on the unfortunate savage. Thirdly, that, perhaps inevitably but most unfortunately, the Mission-educated native does not bear a good name either among his fellow natives or among Europeans. It is, alas! a very generally accepted fact that one should beware of Mission servants, who almost invariably lie, drink, and steal. These arguments won the day and the education of future chiefs was not, generally speaking, entrusted to State-supported Missions. If an opinion may be ventured from an outside view, it is that for the present we might confine the main portion of our energies and our cash to giving the native the chance of a technical education. When funds permit, the formation of a school in Nairobi for the sons of chiefs would no doubt be an excellent idea. As in India, the opportunity of sending the future chief to such an institution would very shortly prove one of the most coveted privileges of each native ruler, and the boys trained therein would be, not a source of weakness, but of strength and loyalty.

The supply of teachers, especially of the lower grades, is rather limited. This difficulty is complicated by the supposed necessity of a six months' holiday after thirty months' service. This implies the necessity of the retention of a considerably larger staff than would be 
ordinarily sufficient. Instruction is given and classes are held by the headmaster in Nairobi to enable pupilteachers to obtain the required certificates. Up to the end of I $1 \mathrm{I}$ I, at all events, the great and ever-increasing stress of work prevented these classes being as successful as could be desired.

It is no unique principle which finds the education authorities, from the Director of Education down to the latest joined pupil-teacher, the target for abuse of all kinds. "Indignant Parent's," letters to the local Press are comparatively as numerous and as virulent as in England. There is nothing new or even strange in finding the parent of either sex show a marked partiality in favour of their own offspring, a partiality which tends to obscure broader issues. This trait is perhaps more marked on the maternal side. Yet if personal prejudices be left aside, it can hardly be denied that great advance has and is being made. It is for "Indignant Parent" to see that this advance goes on at an ever accelerated pace. 


\section{CHAPTER XXIV}

\section{BIG GAME SHOOTING}

So many and such excellent books have been written on this subject that there is little indeed that can be added. Moreover, even had I the ability, which is assuredly not the case, there is certainly not the scope in this work for anything very elaborate. It will be merely my aim to show, as far as I can, where and how the settler and visitor can get as much sport as possible out of the splendid list of game animals which inhabit the Protectorate, together with a few hints for those sportsmen who are at present novices in the art. There are, however, a few phases of the sport, past, present, and future, which may be dwelt on without disadvantage.

In the first days of shooting in the Protectorate, that is in the days before the completion of the railway and the establishment of the game licence, when such great sportsmen as Lord Delamere, Sir Robert Harvey, Sir John Willoughby, Messrs. F. J. Jackson, Hunter, and others came up or down, an expedition into the country was a vastly different undertaking from the same task nowadays. Such expeditions were embarked on, not only with the idea of sport for sport alone, but with the added and higher attractions of 
adventure, exploration, and research. Those who ventured on them had to be the possessors of really stout and determined hearts. They had hardships to face for certain, shortage of water, unpleasant food, and fever; moreover, they had the indefinite and exciting prospect of finding hostile natives and imperfectly known wild beasts whose mischievous propensities prove to have been considerably exaggerated. Against such dangers and privations to be faced there were balanced rewards of great worth : new territory to be visited, new, or at all events more or less unknown, tribes of doubtfully friendly natives to be encountered and studied, and almost certainly new animals or birds to be discovered. As to sport itself, the same comparison holds good, but here I would submit that, from a purely sporting point of view, there is an adverse balance against the older days. In many instances, such sportsmen as I have named struck virgin shooting ground ; the game was very numerous and tame and to slay a quantity of it was an uncommonly easy matter. Nor, indeed, judging by some published lists of bags, can excessive clemency be urged against the early comers. They had, too, the delightful and unrestricted feeling of really shooting Ferae Naturae, wild beasts which belonged to no man. With the coming of licences, schedules, fines, and undertakings to be good, absolutely necessary as they all are, this feeling has gone, never to return. The sportsman of to-day can, however, weigh against this the fact that the game is wilder and more difficult of approach, and the fact that though the quantity of game is no doubt considerably less than before the visitation of rinderpest in 1890 and subsequent years, the habitat of each species is so well known that it is a matter of infinitely greater ease 


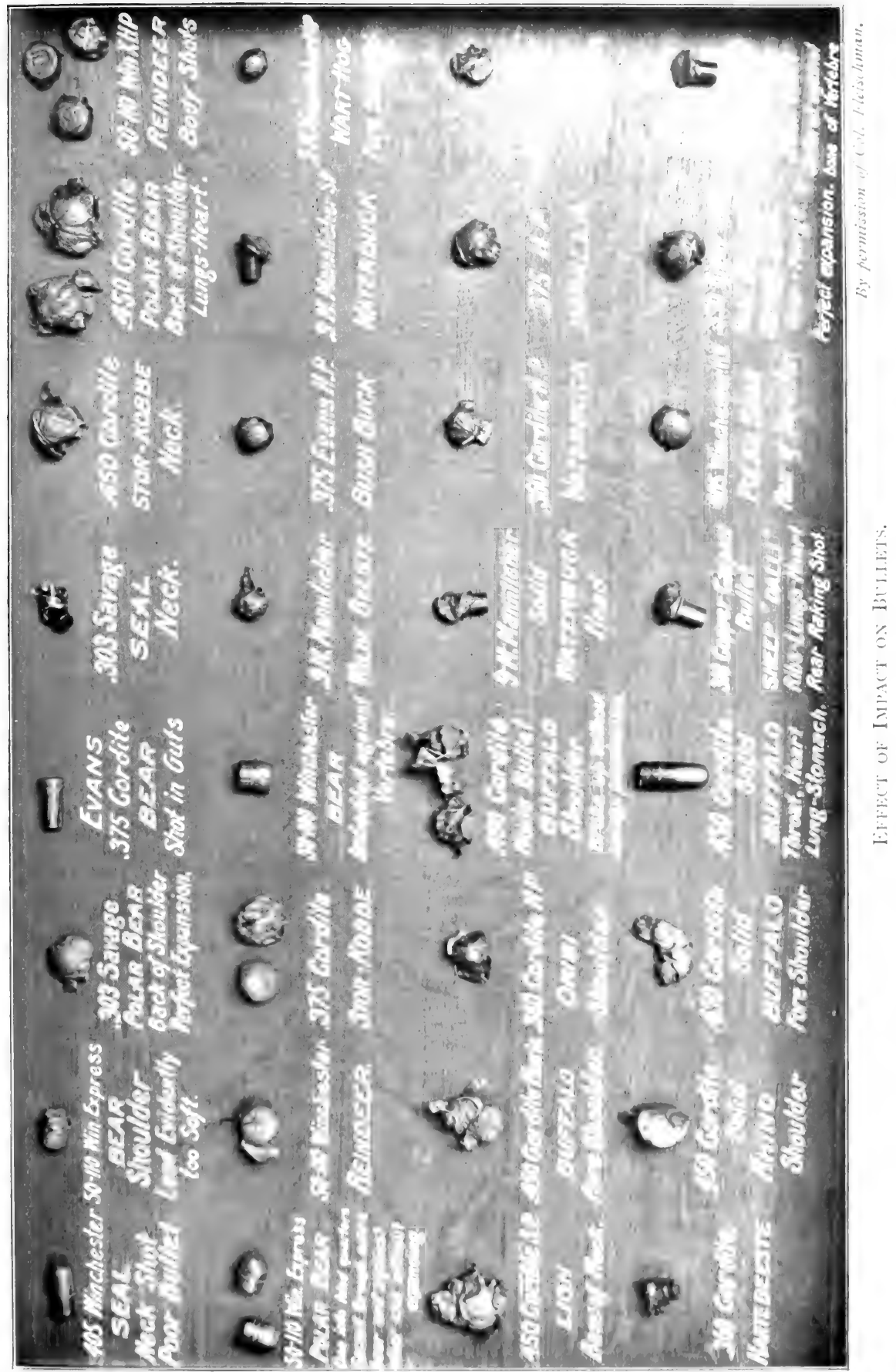



to get a representative bag than formerly. Again, although there are some, there must be very few sportsmen who would not rather indulge in their sport in reasonable comfort. $U p$ to the last year, as each year has passed bags of game have got better, that is to say, variety greater and the average of heads better; while the difficulties, dangers and discomforts have got less, till at the present time a lady of active habits and a tolerably straight eye, accompanied by one of the numerous class of white hunters, can in a couple of months obtain a bag altogether beyond the wildest dreams of the toughest and most adventurous of the old pioneers.

The present is the day of the sportsman, of the man of riches, of the "white hunter," and of the record breaker whom we can generally identify with the American. The sportsman may include, and often does, all the rest, but more often than not he is unaccompanied by wealth, white hunters, or the desire to break records. The Protectorate is now very largely known and explored, and the game is, as I shall show, very widely distributed ; but certain well-known routes still hold by far the largest numbers and variety of game, and it is all along these that naturally the white hunter usually takes his clients. Among such routes are : along the Thika river till it joins the Tana, and then along the Tana to the new Embu Bridge, across Likipia to Rumunuti and so along the N. Guaso Nyero river, up to and around Embu, in the neighbourhood of Simba and Makindu, across the Uasin Guishu plateau and along the Nzoia river, through the Loieta plains to the Amala river and the German boundary, or along the S. Guaso Nyero. Along these routes the white hunters hurry their employers, 
and if some of the spirit of adventure is a little dimmed by the continual passing of old camps and the tripping against empty jam tins, the sport is still firstclass and nearly if not quite as good as ever it was. The white hunter himself is an institution of the last three or four years. The usual type speaks Swahili, the language of the Safari, acts as go-between to porters, servants, gun-bearers, and their masters, oversees all the detail and routine of the camp, and finally draws a very considerable salary. He in fact smooths the way and is an immense convenience to the shooting tourists, to whom he also secures at least double the bag which they would otherwise obtain. There are, moreover, many who are, in addition, both sportsmen and naturalists, and whom, if they will consent to go, it is a pleasure and privilege to accompany. The record-breaker is an unpleasant feature of the present day; he is, I regret and say with due reluctance, usually an American, and his object is to go one better than his neighbour, or perhaps, rather, than his compatriot, either in the numbers of his bag, or in the variety of it, or in the peculiar way in which it was obtained. An example of the first is such a one as has, more than once, been observed browning a herd of Impalla or Hartebeeste, leaving the heads and carcasses on the ground and giving as an excuse that his time was nearly up and that he had not completed the totals allowed on his licence. The second, whose record is to be variety, accomplishes his object by including among the slain such species of game as giraffe, baboons, monkeys, snakes, crocodiles, jackals, cats, rats, etc. While in the third class may be found the man who procures his game with a lassoo, a trap or from a balloon. I would not have it thought that I 


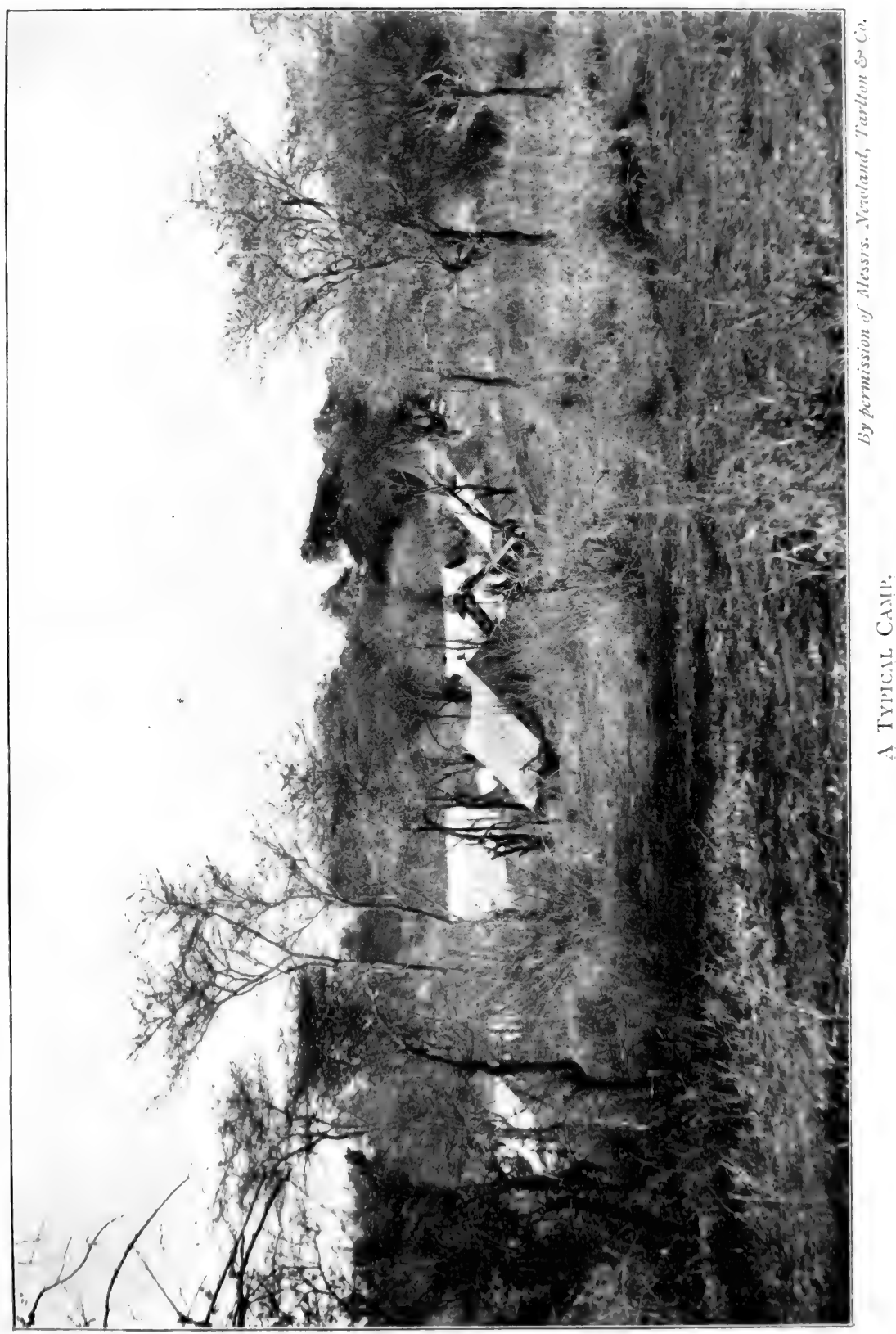



would imply that the day of the sportsman in East Africa is over; on the contrary, probably more real genuine sportsmen visit the Protectorate than ever before, among whom, indeed, many of the very best are Americans; but merely that the diminution of discomfort has caused a far greater admixture than was the case even four or five years ago. There still remain, however, two classes of shooters whose name is almost synonymous with sportsmen; one, of course, is the British officer and the other is the Austrian. It is, perhaps, a pity that all our sporting visitors are not made after the same model.

What, however, of the future of the sport? It must be obvious that so grand and fertile a country as this Protectorate cannot long remain a sportsman's paradise in the sense that it is now. Indeed, signs are not wanting that the zenith is already past. For many years the pastoralist and agriculturist has been steadily occupying areas which were formerly given over to game alone. Till recently it is true that new tracts were opened to the sportsmen as fast as, if not faster than, the encroachment on his former haunts. Thus as the Athi plains were taken up for settlement and to a great extent shot out, Likipia was opened up; as the same thing happened to Likipia, the Uasin Guishu plateau, abounding in elephant, waterbuck, reedbuck, and black-maned lions, was discovered. When again this tract was given up as a settlement for indigent Boers, pioneer sportsmen crossed the waterless tract to the West of the Kedong Valley and another splendid virgin shooting ground on the Loieta and Lemmik plains was disclosed. But now, alas! the day of new and most delightful surprises has gone by. To the north of the Guaso Nyero river or at

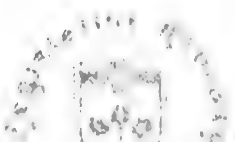


all events of Marsabit is desert right up to the Abyssinian frontier, to the west and south-west lie the borders of Uganda and German East Africa, while to the coast and south-east lies a stretch of country much of which holds plenty of game, but which is at the same time nearly all full of thorns, fever, and discomfort. In the existing areas where shooting may be enjoyed in health and comfort, where even an invalid accompanied by his wife and daughters can share the sport, the game is slowly but surely disappearing. People look round with wonder and search for the cause. Need they look further than the fact that for the last two or three years some thirty or forty parties of sportsmen have in this small area accounted for 300 head each? There are many who talk largely of thousands or tens of thousands of head in a herd of game. Let them climb to the top of a knoll and try conscientiously to count such a herd. They will be astonished no longer at the numbers but rather at the sparseness of a herd they had thought uncountable. It is true that a great proportion of this slaughter is of common game and is to a certain extent counterbalanced by the killing of vermin such as lions and leopards, which would of itself have been responsible for much destruction; still the rarer varieties suffer as well, and with regard to them it is perhaps worth noting the devastation that is done in the name of or on behalf of museums. Do those nine white rhinoceros ever cause ex-President Roosevelt a pang of conscience, or a restless night? I for one venture to hope so. It is unfortunate that we have no close season either enforced or natural. But the former is almost impossible, as calving time is never constant, but varies both 
according to locality and different species of game. Nor does the grass ever grow long enough to enforce a natural close season as it does in British Central Africa, Uganda, and other countries. Still, diminishing though the game undoubtedly is, it would probably stand in quite sufficient numbers for many years to come. There is one factor, however, which will end the present phase of big game shooting long before that period; this is the settler, who in the next two or three years will have reclaimed and occupied the whole of the present and healthy part of the game country which is not otherwise specially reserved.

Let us therefore look ahead and try to sum up what portion of this great sport is likely to be indefinitely preserved to us. In the first place, the settlers themselves are likely to preserve a great deal of game. Not certainly, except in rare instances, the huge herds of zebra and hartebeeste which are responsible for nine-tenths of the damage and for ninety-nine-hundredths of the outcry against preservation of game; indeed this would be unreasonable to expect, but with the further exception of the rhinoceros and the large carnivora, distinctly undesirable residents on a farm, we may, I think, calculate on the preservation of all other species. The present farmers have, indeed, already shown a strong tendency this way, even to their own disadvantage, as witness the entire preservation of hippo in Lake Naivasha, and of eland throughout the Rift Valley. Assuredly in the future we may look to the presence on many farms of eland, waterbuck, wildebeeste, impalla, bushbuck, Thomson's gazelle, reedbuck, etc., which will afford the owner and his guests both excellent sport and welcome change of food. Of course, from such pleasant anticipations our 
brother Boer must be excepted; for, save in the rarest instances, he will first clear his farm of every living thing and then proceed, if possible, to repeat the process on that of his neighbour. There are also likely, in suitable situations, to be private game reserves with shooting lodges built on them which may be hired and where sport as sport is likely for very many years to come to be as good as it was even in the earliest days. Such spots will, of course, be rare and only on such areas where the method forms the most profitable means of utilising the ground. At present there exist at least two such Reserves, and the number is likely to be augmented in the near future. Then there are the native Reserves, but from them I venture to think that we cannot expect much. There used to be a pleasing theory that game would always be thick in the Masai Reserves because this tribe are not hunters of game. It is perfectly true that the Masai do not hunt game for food; they have but one thought and that is cattle and sheep, but as surely as the game interfere with the grazing for their enormous herds of cattle and sheep, so surely will the game be banished. To this fact anyone who has trekked across Likipia of late years can bear eloquent testimony. There are also the Forest Reserves and areas, and here there is great hope of sport for many generations. The forests are full of splendid game : elephant, rhino, buffalo, bongo, bushbuck, leopards, the giant hog and other pigs; this game does good rather than harm in that it eats the grass and other undergrowth and considerably lessens the danger of forest fires; its enemies in the shape of hunting tribes should be easily kept in check, and finally hunting and shooting in bush and forest is probably finer sport 
than any form of plain hunting. Lastly, there remain the hot, inhospitable, waterless, and unhealthy portions of the Protectorate, areas which are unlikely for very many years to be taken up and settled and which form a very considerable proportion of the whole Protectorate. Here among the thorns and sand many such species as elephant, rhino, giraffe, eland, oryx, gerenuk, Grant's gazelle and kudu will indefinitely afford sport for those who are prepared to pay the price in work, sweat, and discomfort. Here, too, will be the last stronghold of the noblest of them all, the lion.

It is generally considered advisable to insert a paragraph or two as to the danger attendant on and considered an integral part of the sport of big game shooting. I must confess to not being in agreement with the theory that danger is such an essential element of the sport. It is true that it adds an additional spice to the pleasure of those who enjoy it, and also a very agreeable method of impressing the ignorant around the smoking-room fire. If, however, the danger forms the essence of the sport, why go further than a meadow where there is a herd of cattle, polled for choice, and an impracticable fence; then, having locked the gate, proceed to compass the death of the bull with a small bore rifle. More 'sport' could be guaranteed than from any beast in the Protectorate. Being of a cautious nature, I can affirm, even from my small experience, that the amount of necessary danger has been very greatly exaggerated. It is, I suggest, considerably less than in hunting and infinitely so than in driving partridges over a low fence between two jealous shots who have lunched not wisely but too well. I should imagine 
that by far the greatest danger occurs in attempting to secure a bull elephant out of a herd of cows either in thick thorn bush or bamboos, possibly, however, this opinion is based on the theory of omne ignotum pro horrifico. Onehint may be ventured on to other cautious members : that is to get as close as possible to dangerous game before firing the initial shot; this in case of the elephant, rhino, or buffalo should be usually inside of forty yards, especially of the first two, asserting repeatedly to one's quaking heart that not one animal in a thousand bears you any ill-will until you start on his molestation. 


\section{CHAPTER XXV}

THE GAME ANIMALS OF THE PROTECTORATE

In considering the principal varieties of the larger wild fauna of the Protectorate it is proposed to do so, as far as possible, mainly from the settler's point of view.

Wherever the newcomer may elect to settle he is absolutely certain to become intimately acquainted with Big Game. Even if he is a townsman he cannot fail to be provided with a topic of conversation, a topic so universal and inexhaustible that unless he be a naturalist or sportsman he stands a more than fair chance of being thoroughly bored by the subject. If, however, he be a farmer he will come tc be on even more intimate terms with the wild animals. Certain species will provide him with sport. Certain species will provide him with food or hides which will prove useful and be utilised for ropes and harness. Others will harass his stock and sheep; and yet others will destroy at intervals his crops and fences. While with others, again, he will only become acquainted if sport or work takes him into the uncivilised portions of the Protectorate.

Although many animals will be seen to come equally within two or more of these categories, it is on these general lines that we propose to treat them. 
The following list constitutes what are generally held to be the game animals of the Protectorate :-

(I) The elephant.

(2) Rhinoceros.

(3) Hippopotamus.

(4) Buffalo.

(5) Lion.

(6) Leopard.

(7) Cheetah.

(8) Bongo.

(9) Greater Kudu.

(Io) Lesser Kudu.

(i ) Sable antelope.

(i2) Roan antelope.

(i3) Waterbuck (defassa).

(I4) Waterbuck (ellipsiprymnus).

(15) Wildebeeste.

(I6) Sitatunga (Speke's Tragelaphus).

(I 7) Bushbuck.

(I8) Bushbuck (Haywood's).

(19) Common oryx (Beisa).

(20) Fringe-eared oryx.

(2I) Waller's gazelle or gerenuk.

(22) Grant's gazelle (Typica).

(23) Grant's gazelle (Notata).

(24) Robert's gazelle.

(25) Bright's gazelle.
(26) Peter's gazelle.

(2i) Soemmerring's gazelle.

(28) Thomson's gazelle.

(29) Eland.

(30) Klipspringer.

(3I) Common zebra.

(32) Grevy's zebra.

(33) Hunter's antelope.

(34) Ward's reedbuck.

(35) Chanler's reedbuck.

(36) Common oribi.

(37) Oribi (Kenyaensis).

(38) Common duiker.

(39) Harvey's duiker.

(40) Steinbuck.

(4I) Dik-dik (Guenther's).

(42) " (Kirk's).

(43) " (Hinde's).

(44) Topi.

(45) Impala.

(46) Hartebeeste (Coke's).

(47) "' (Jackson's).

(48) " (Neuman's).

(49) Suni.

(50) Thomas' cob.

(51) Wart hog.

(52) Giant hog.

(53) Bush pig.

(54) Common giraffe.

(55) Giraffe (reticulata).

(56) Lynx.

To these varieties others are occasionally added, more especially by those who wish to establish a record in varieties slain :- 
The wild dog.

The spotted hyæna.

The striped hyæna.

The crocodile.

The serval.
Jackal.

Pythons and other snakes.

Baboon.

Collobus monkeys.

Marabout storks.

Wild cats of various kinds. Blue and other monkeys.

There is nothing laid down; and what is or is not a game animal is a matter for individual taste.

It is by no means certain that all the larger mammals of the Protectorate have yet been identified. Indeed, the probability is rather the other way. If such animals remain for discovery, their habitat is almost certainly the greater forests. Some years ago the writer was convinced in his own mind that he saw at close quarters, about sunset in forest, a very large pig with a perfectly white mane. The story was received with much incredulity, ridicule, and hints of bibulous visions, but the existence of such an animal has since received corroboration.

Natives report the existence in the great Mau forest, not only of a huge ape, but of what is apparently a bear! Moreover, they are confident of the presence of a very fearsome beast, to wit the gu-gu. This animal is of huge size, very fierce, and apparently of the monkey tribe. All accounts are agreed that he has but one eye and a huge spike at the end of one arm. The following story will prove that this animal is not without European confirmation.

A certain settler lived with his wife on rather an out-of-the-way farm on the edge of a huge forest. Business forced him to absent himself, leaving his wife alone to manage the farm. The poor woman had not been left alone a week when the head boy came in and 
reported that the safety of the homestead was menaced by the arrival of a gu-gu. After describing the malignant propensities of the beast, the native invited the lady's attention to the garden. There, clearly imprinted in the flower-beds and in the dust, was the spoor of some large and curious animal. Inspection proved that the beast had approached and possibly scaled the house during the night, but had retired towards some thick jungle during the day. In a frenzy of terror the settler's wife inquired how the immediate danger might be averted. Luckily the head boy knew. He informed her that if she would place one pound of sugar and five pounds of rice on the floor of an outhouse the gu-gu would be attracted by these, would eat them and do no harm to the human inmates. The boy proved right. In the morning the tracks led plainly to and from the hut and the rice and sugar were gone. Truly thankful for the scientific knowledge of her boy, the lady nightly placed the sugar and rice in the outhouse and all went well. The food was always taken, and not a hair of either the lady or her children was injured. Curiously enough, though the state of fear kept the unfortunate lady drawn and thin, her head boy grew more rotund of stomach daily; a fact which proves how differently human nature is constituted. On the day the master came back a strange thing happened. The head boy disappeared, never to be seen again, and from that day no further trace of the gu-gu was seen near the farm. One can only suppose that the gu-gu, satiated with its orgy on the unfortunate boy, had retired once more to the depths of the primeval forest.

To revert to the more generally known fauna with which the settler may become acquainted. The following beasts are those which may be regarded as likely to provide sport :- 
Lion.

Leopard.

Cheetah.

Buffalo.

Bushbuck.

Warthog.
Impala.

Lesser Kudu.

Chanler's Reedbuck.

Klipspringer.

Duiker and other smaller buck.

The following will provide excellent meat, useful hides or both :-

Eland.

Waterbuck.

Wildebeeste.

Hartebeeste.

Topi.
Grant's gazelle.

Thomson's gazelle.

All the smaller buck such as duiker and dik-dik.

Young pigs.

Certain varieties will do him nothing but harm, though some are interesting, and as a naturalist many a settler is prepared to stand the loss rather than risk their extermination. Such are :

Rhinoceros,

Hippopotamus,
Zebra,

Reedbuck,

Bush pig,

and apart from the question of food hartebeeste and topi.

The following varieties are not likely to affect the resident farmer, since they are mainly to be found either in forest or beyond the confines of civilisation :-

The elephant.

Bongo.

Greater Kudu.

Sable.

Roan.

Sitatunga.

Oryx.

Gerenuk.

Grant's notata and brightii Lynx.
Hunter's antelope.

Soemmering's gazelle.

Peter's gazelle.

Grevy's zebra.

The giant hog.

Hunter's antelope.

Giraffe.

Thomas' cob. 
Still, many a settler will be prone to spend a holiday after many of these species, some of which are capable of providing excellent sport, more especially elephant, greater kudu, bongo, and sable.

Towards various species, therefore, the average settler will have mixed feelings. Thus he will have the utmost admiration and respect for the lion on account of the great amount of sport which the latter is capable of providing. The same beast he will detest and abhor when it stampedes his bullocks or decimates his sheep or ostriches. The buffalo, again, will give many a sporting moment, and, in addition, provides a hide which is extremely useful on the farm. The species labours, however, under the taint of giving encouragement to the tsetse-fly, and that suspicion even is not a desirable adjunct to a farm. Again, he will dislike and probably clamour for the extermination of the hartebeeste when he finds a broken fence or a trampled field of corn; but he should bear in mind the almost innumerable days on which a leg or steak of "kongoni" has stood between him and starvation, not to mention the many uses to which he has put its hide. Certain animals seem to stand beyond the pale and to be, speaking plainly, an unmitigated nuisance. Such are the rhinoceros and the common zebra. They provide no sport and they provide no food. No ordinary fencing will stop a single rhino or a herd of zebra ; moreover, the former are apt to be troublesome if not a distinct danger. The only useful end I know which the living rhinoceros affords lies in the hair-breadth escapes with which he provides every touring sportsman, and even these thrills are treated with more scepticism than of yore. His carcase, however, forms the best of all lion baits. A herd of zebra in the sunlight form a lovely 
picture, and those who ought to know say that pigs will eat their flesh. Further than this in their praise I cannot go.

Every settler who comes out to the Protectorate will wish for one or more rifles in addition to a shot gun. Whatever calibre or description of rifle he brings out, it may be certain that he will wish that he had made a different choice. Confident that that will be the case, I nevertheless recommend that if one rifle be brought it should be a magazine 375 or 360 ; while if two are brought I would suggest a $\cdot 256$ and a double $\cdot 400-450$. A $\cdot 375$ is rather too big for the smaller antelope and hardly powerful enough for dangerous game. It can, however, be made to serve for both. If a third be added, possibly by an indulgent relative, let it be a double 360 , the gun par excellence for lion shooting.

In dealing with the various animals I shall confine my attention first to those animals which are likely to provide the settler with sport. And among these the lion undoubtedly heads the list. 


\section{CHAPTER XXVI}

ANIMALS WHICH PROVIDE SPORT

The Lion.-Lions are distributed in greater or lesser quantities throughout every portion of the Protectorate, civilised and uncivilised. He may be heard on the mainland from the island of Mombasa. $\mathrm{He}$ wanders round the shores of the Great Lake. $\mathrm{He}$ lives in great numbers on the barren deserts to the north. He still invades, not only the golf-course which adjoins Nairobi, but even during a severe drought the very town itself. Everyone sees at least one lion from the windows of the first train that takes him into the country. No one sees him from the train that takes him out. And what we should do without him in the bars and clubs and other places where drink and gossip abound I shudder to think.

One of the most curious of the many curious facts about the lion is the way in which his numbers are kept up, if not actually increased. In 1905 about forty lions were killed; a number far in advance of any previous total. We were told that his extermination was at hand; and big game shooters were advised to hurry up and make the most of their chance, since a year or two would see the lion a rara avis indeed.

In I9IO and I9II no less than 795 lions were 248 
accounted for, and the cry is still they come. Moreover, this total makes no account of the large numbers which creep away to die from poison and other causes. It may be anticipated that as long as there is game about the lion will always be with us. $\mathrm{He}$ is a very prolific beast and also a very hungry one. The probability is that a great many more lions die from hunger while young than from any other cause. Therefore, up to a certain point, the more that are killed will only mean that a greater proportion will survive in the ordinary struggle for existence. Many authorities say that each lion kills on the average a beast once in four, three, or even two days. It seems to me that this must be an exaggeration, when one considers the great quantities of lions that exist in certain districts where troops of a dozen and over are quite common. If it were true there would not be enough, or nearly enough, animals in existence to supply their appetites. I would suggest that the shortest average interval between the kill of each adult lion is at least ten days. There is a possibility that a moderate amount of shooting actually increases the stock, as is the case with partridges. The large parties are divided up and a greater proportion of old males are killed off.

Lions are mostly obtained by the following methods : -(I) Chance. (2) Riding down on horseback. (3) Tracking the spoor till the beast is marked down in a gully or clump of bushes from which it may be driven. (4) Laying out kills and visiting them at daybreak. (5) Sitting up over water or over a kill at night. (6) Spearing them, as is done by the Masai and Nandi. (7) Baying them with trained dogs. (8) Traps. (9) Poison. 
Of these methods the last three are the most effective, and, where it is desirable that the vicinity should be rid of vermin which are doing damage to stock or sheep, must be resorted to. There is the additional advantage that practically no danger attaches to any of these methods. The use of strychnine, unfortunately, almost invariably destroys the skin, by causing the hair to become loose, and thereby lessens its commercial value. The palm for sport must be awarded to the traditional method of the Masai and Nandi, who run the lion down on foot and despatch him with their long-bladed spears. The blades of these spears are often more than 3 feet long, and a warrior can hurl them with such force that they will completely transfix a lion and stand out a foot on the far side. Fatal accidents are far fewer than might be imagined. When the beast charges he is met by a phalanx of locked shields, and his end comes before he has time to do much damage. The chief danger is caused by the eagerness of young warriors to get the first spear in, and thereby to become the possessor of a lion's mane head-dress, the desideratum of every young man.

The most sporting methods for Europeans are riding down and tracking. The modus operandi of the former method is as follows. Having come to an open portion of country which is known to be the habitat of lions, four or five horsemen line up at the very crack of dawn at intervals of some 200 yards. When the quarry is sighted he is pursued by the nearest horseman, the others joining in on the flanks and attract the beast's attention should he attempt to turn on his nearest pursuer, which is seldom the case. Except for the first few bounds a comparatively slow pony has 
the heels of a lion. After about a mile the lion isb lown and takes refuge, facing his pursuers, under the nearest bush. The gun whose turn it is to shoot if more than one be armed, then dismounts and advances for the shot. Nice judgment is now required, as it is desirable to get near enough to make a pretty certain shot, yet not so near as to excite a premature charge. Experts put the crucial distance at from forty to fifty yards. There can be no question as to the grandness of this sport. It is unfortunate that the portions of the Protectorate suited for galloping, always limited, are getting denuded of lions, which are retiring more and more to bush or rocky country. Tracking up lions is an equally fine sport, but is not so general as it might be in the Protectorate, owing to the great inferiority of the native trackers, who can only spoor in desert sandy country or in long grass after heavy rain. The excitement of the sportsman may be imagined who has followed the mighty spoor for mile after mile over sand, through gullies and open bush till it disappears in a small dense clump of jungle, and the most careful search detects no mark of exit. It was by this method that Lord Delamere, the prince of lionshooters, made the greater proportion of his bag. Single-handed, he has accounted for close on seventy lions, more than twice as many as stand to the credit of any other sportsman. He holds a far more wonderful record still. Of the first forty-nine lions at which he fired and wounded he did not lose a single one! Next to Lord Delamere, the most famous lion-hunters in East Africa are the brothers Hill, ostrich farmers on the verge of the Athi plains, and Mr. A. B. Percival, the game-ranger. These splendid and unassuming sportmen have obtained most of their large totals by 
the riding method, and by their unique knowledge of the habits and haunts of lion.

Lions are very conservative in their selection of homes. Once a lion has chosen his lair, by no means the most obvious in the neighbourhood, he will stick very closely to it. What is more, if his lair be driven and the occupants killed, it is not improbable that their place will almost immediately be taken by others. When, therefore, a real lion expert discovers traces of lions, in a locality with which he is acquainted, either by hearing them at night or seeing their spoor, he will say at once that they are lying either in such and such a gully or on such and such a hill-side.

Perhaps to the ordinary settler chance still affords the most usual method through which he may become the possessor of a lion skin. It may be that one evening, when returning from the pursuit of his dinner, he will turn the corner round a bush and find himself face to face with the quarry for which he has longed so earnestly, but for whose closer aquaintance he now feels suddenly somewhat less disposed. Or, again, one morning when about to set out the day's work a native will stroll in to say that he has just seen a nice party of lions take refuge in a gully. While it is said with more or less truth that every lionhunter will in the end be mauled if he persists long enough in the sport, a larger percentage of accidents takes place among irresponsible and inexperienced shooters, more especially when several such spirits are banded together. Two is, perhaps, the best number of guns to shoot a lion, though it is run close by one; beyond two every gun adds to the chance of an accident. This is partly so because each man is apt to vie with his neighbour in daring, not to say 
foolhardiness; partly because each gun is apt to place reliance on the other guns instead of mainly on himself.

As to the best weapon for this purpose, each man has his own fancy. There used to be many who averred that a ${ }^{2} 5^{6}$ Mannlicher was as good as a large bore, but the growing list of fatalities has convinced all but the most obstinate that a heavier weapon, and a doublebarrelled one at that, is essential for a modicum of safety. There are good sportsmen who declare that a shot gun is the acme of safety for a charging lion. Maybe it is, if the shot be held till the beast is within three or four yards. The sportsman therefore, would be well advised to be assured that his nerves are in first-rate order before trusting implicitly to such a weapon.

A full-maned lion is a splendid trophy, whether he be black or tawny. The manes on some lions turn black at an earlier age than those of others ; but probably the mane of every lion turns black eventually if time be given it. The higher and colder the altitude the thicker and finer the general average of manes; though by far the finest lion ever seen by the writer was down by Lake Natron where the heat is intense. Lions inhabiting bush and forest country have practically no manes. Some say that they are of a different variety. Others that the manes are pulled out through contact with the thorns. As to size, there seems little variation. Ten feet from nose to the tip of the tail for a lion and 9 feet for a lioness would be quite exceptional measurements. It is doubtful whether ro feet 6 inches has ever been reached. Stretching the skin will do wonders, and at least an extra two to three feet can be attained. Those of us who like large skins-and 
who does not?-are well advised if we stretch the skin for breadth as well as length, thereby preserving a better proportion and exciting less suspicion.

Both lion bites and lion scratches give rise to bloodpoisoning. In the case of claw marks, it is easy to understand, since the concave surface of the claw is often filled with decaying flesh. The case of bites is different since the teeth present an appearance of polished cleanliness. Every settler should have on his farm a syringe and a bottle of glycerine and carbolic. This he should have handy when travelling through lion-country. He need not think because he hears no lions by night that there are necessarily none about; lions, where much hunted, roar seldom, if at all. If every tooth or claw mark be thoroughly cleaned and syringed out with the antiseptic in question-a cruelly painful process - the chance of blood-poisoning ensuing with fatal results is reduced to a minimum.

Lions are most plentiful in the following portions of the Protectorate. Both Games Reserves, the Athi, Kapiti and Yatta plains, all thick bush country, along the banks of the Thika, Tana, North Guaso Nyero, South Guaso Nyero and Amala rivers and the desert country round Lake Marsabit.

Nearly every sportsman-settler, official, or visitormust have a soft spot in his heart for the lion, if only for his magnificent sporting qualities. Elusive to bring to bay, he is a gallant foe when cornered. I think that there are very few in the Protectorate who would not feel that we should be the poorer for the extermination of the lion, and on his behalf I would put in a little plea. There is no manner of doubt that where lions are a menace to the possible safety or prosperity of settlers, they must be banished, and to that end there can be 
no means too unsporting or too drastic. There are, however, large tracts of country far from the haunt of man where the lion does no harm and effects no worse purpose than to keep the balance of nature exact. Is there any reason why in such districts he should still be the victim of ruthless slaughter, and to no other end than that another American should hold yet another record? I submit that it could do no harm if in such out-districts the lion were put on the same footing as other, and in some cases less desirable, game animals, and that the number obtainable on each sportsman's licence be limited. The advantage to the Protectorate would not be merely sentimental, but also pecuniary. With this short notice we must leave a fascinating subject, expressing the hope that it may be many a long year before the grunt of the lion may be heard no longer over the barren tracts of the Protectorate.

The Buffalo.-Next to the lion, the buffalo provides the most general sport to settlers, and a trophy even grander than the former. Buffalo haunt the verge of a considerable number of farms and are within a week-end journey of the majority. They were formerly to a great extent plain dwellers, and quite one of the most common species in the country. The rinderpest at the end of the last century played havoc with them; so much so, indeed, that it was feared that they were absolutely exterminated. Three or four small herds did actually survive, and these have multiplied so wonderfully that buffalo now exist in thousands. In 1910 and I9I more than 700 were killed. Very wisely, however, they have never resumed their plain-loving habits, but are mainly to be found in thick bush or forest. The only places where 
there is now a reasonable chance of finding buffalo in the open are in the large swamp where the South Guaso Nyero disappears, and along the Tana and in the Ithanga hills around the shooting box belonging to Sisal, Ltd.

Tracking buffalo in forest or thick bush must always be intensely exciting and somewhat risky work. Unless single solitary bulls be followed, it is extremely difficult to be certain of the sex of a great dark body which suddenly crashes away. Solitary bulls, moreover, bear an evil reputation, and natives are very averse to following them into thick cover. They are quite capable of making an unprovoked attack, while herds of mixed bulls, cows, and calves will invariably stampede. If a buffalo charges, he probably does so in a very determined fashion, and it is worth bearing in mind that it is next door to impossible to give him an immediate fatal blow as he comes. The safest method is to jump aside, and fire behind his shoulder as he passes, if he does pass. A better way is to avoid tracking up single bulls in thick bush altogether. There will usually be found some small glade or similar spot where the herd come out to graze during the early mornings or late in the evening. When this has been discovered a fine head may be selected with fair ease. Following wounded buffalo is most dangerous, and should be avoided as far as possible by ensuring that the first shot is correctly placed, which, with many of us, can only be done by firing within, say, 40 yards as a maximum. Horns run very large in the Protectorate-far larger than in South Africa or along the Nile. The system of measurement in vogue, i.e. to take the greatest breadth of the outside edges of the horns, is most unreasonable, 
and is no real test of the merits of a head. Thus I saw a head shot in r910 by Lord Wodehouse, which officially measured 44 inches, but which was i 3 inches longer than a 50-inch head shot about the same time had the two heads been measured in the same way that antelopes' or goats' horns are measured. The sportsman may be well satisfied with anything over 40 inches provided that they give evidence of belonging to an old bull. To my mind there is no grander trophy, and the old Adam dies so hard that I venture to think that it must be some time yet before the sentimental ideal is realised and we return as happy with a mere photo obtained by the most skilful of stalks as with the actual trophy.

Buffalo are common in the following localities : all thick bush along the coast in the neighbourhood of water, the Tana, the South Guaso Nyero and Lake Natron-here they exist in thousands but the general average of heads is not very high, the Mau forest and the Ithanga hills-which two places probably hold the best heads of any, Lake Marsabit, the N'Gong hills, the Aberdare mountains, and North Guaso Nyero river. But these by no means exhaust the localities where the animal may be found.

Most of its haunts are such that it inflicts little if any damage on the settler. There is one charge, however, under which the buffalo is a suspected person. $\mathrm{He}$ is vehemently accused, and as vehemently defended, of the charge of bringing and being responsible for the presence of the tsetse-fly (Glossina longipennis or Glossina morsitans) so fatal to cattle or horses. It has further been definitely proved within the last few months that Glossina morsitans is capable of transmitting sleeping sickness. Since enthusiasts on both sides wax 
so hot on this question, it may be presumed that the evidence is by no means conclusive. In this Protectorate, however, the balance of probability seems to be in favour of innocence, and for the following reasons : there are very many districts in which there are tsetse-fly and no buffalo, and others again in which there are buffalo and no tsetse-fly. This argument seems to me a pretty strong one, though I must confess to being prejudiced. There is a commission now sitting to weigh the evidence on both sides. All good sportsmen must hope that the verdict will be favourable to the buffalo, since not only is he a glorious animal, but he seems one which may exist in the great forests and swamps even under the closest of white settlement.

The Leopard and possibly the Cheetah are capable of providing sport to the settler, and both of them form highly prized trophies. The leopard, unfortunately, can only be classed as a most mischievous vermin. Not strong enough to tackle cattle, he is a scourge to both sheep and ostriches, and no means are too unsporting to banish him from their vicinity. Probably poison is the most effective way, but a box trap is generally successful, and has the additional advantage that the skin is thereby preserved. In his wild state a leopard's staple food is formed by duiker, small buck and guineafowl, and where these exist in large numbers one may be pretty sure of his presence. Larger specimens are very partial to impala, and will even pull down hartebeeste. They are extremely powerful and will carry off a ram impala or bushbuck of near $200 \mathrm{lb}$. a great distance, and occasionally right up a tree. Even greater caution should be used in following a wounded leopard than a lion, since they are so much quicker in attack, and are also capable of leaping down on the 
hunter from the branch of a tree. They may be obtained by laying out a kill and visiting it in the early morning. Also there is a good chance where they are numerous of coming across one by creeping round the edges of forest at dawn or sunset. Anything over 7 feet is a fine leopard, and about 8 feet would represent the maximum growth, while full grown specimens are often less than 5 feet. There is hardly a corner of the Protectorate where they do not exist. Perhaps they are more numerous than anywhere along the Athi below that point which most closely adjoins the Thika.

The Cheetah is widely distributed wherever there are plains. Yet, although it has always no doubt been common, the first specimen killed by a European was obtained, I believe, by Sir Robert Harvey in 1905. Now probably at least thirty or forty are bagged yearly. It is usually held that the cheetah is the fastest sprinter amongst all animals. Such an estimate is based purely on hypothesis, and while having every respect for the powers of the former, I do not believe for a moment that a cheetah could cover 200 yards in the same time as a good greyhound or even whippet, i.e. about 6 seconds. The cheetah lives on Thomas' gazelle and smaller buck, and no doubt takes his toll of sheep, though I have never heard personally of one being actually caught fagrante delictu. Writers in the early days of big game shooting in South Africa describe the cheetah as killing kudu, a feat one would have thought beyond the power of his teeth or claws. Certainly he attempts no such strenuous work in East Africa. The writer had the pleasure of witnessing the successful chase of a Thomas' gazelle on the part of a cheetah. The 
former had a start of about 200 yards, but was pulled down in approximately half a mile. The length of this chase is far in advance of the average course of tame cheetahs in India. There 300 yards is an unusually long course, and after that, if unsuccessful, the pursuer will stop, retire in disgust, and sulk. Although we were not more than a hundred yards from the death-scene, it was difficult to see what had actually happened when the quarry was overtaken. All was over in a flash, but the impression of an upraised striking paw was left, perhaps wrongly, in my mind. Death was instantaneous, but although I skinned the victim, a fine male, I was unable to discover a single claw puncture; nor, as far as one could tell, was the neck dislocated. This animal stands in grave danger of extermination in the Protectorate, and on a sportsman's licence, at all events, might well be to a certain measure protected. A male cheetah varies in length from 7 feet to slightly more than 8 feet.

The Bushbuck and Lesser Kudu are animals which provide pretty bush stalking and also furnish a really lovely trophy. The former is better known to farmers, since he is ubiquitous wherever there is bush cover, and also water. The latter requires arid country. Nearly all settlers are able to have an occasional shot at a bushbuck, and although he is certainly destructive to young crops, much is forgiven him for his beauty. Where not much molested, they feed in the open well into the day, but soon learn that with the dawn comes danger. The bushbuck runs very large in the Protectorate-a fine buck weighing well over $200 \mathrm{lb}$. The horns are proportionately good, and have been known to exceed 20 inches. The sportsman, however, may be satisfied with anything above 14 inches. It is 

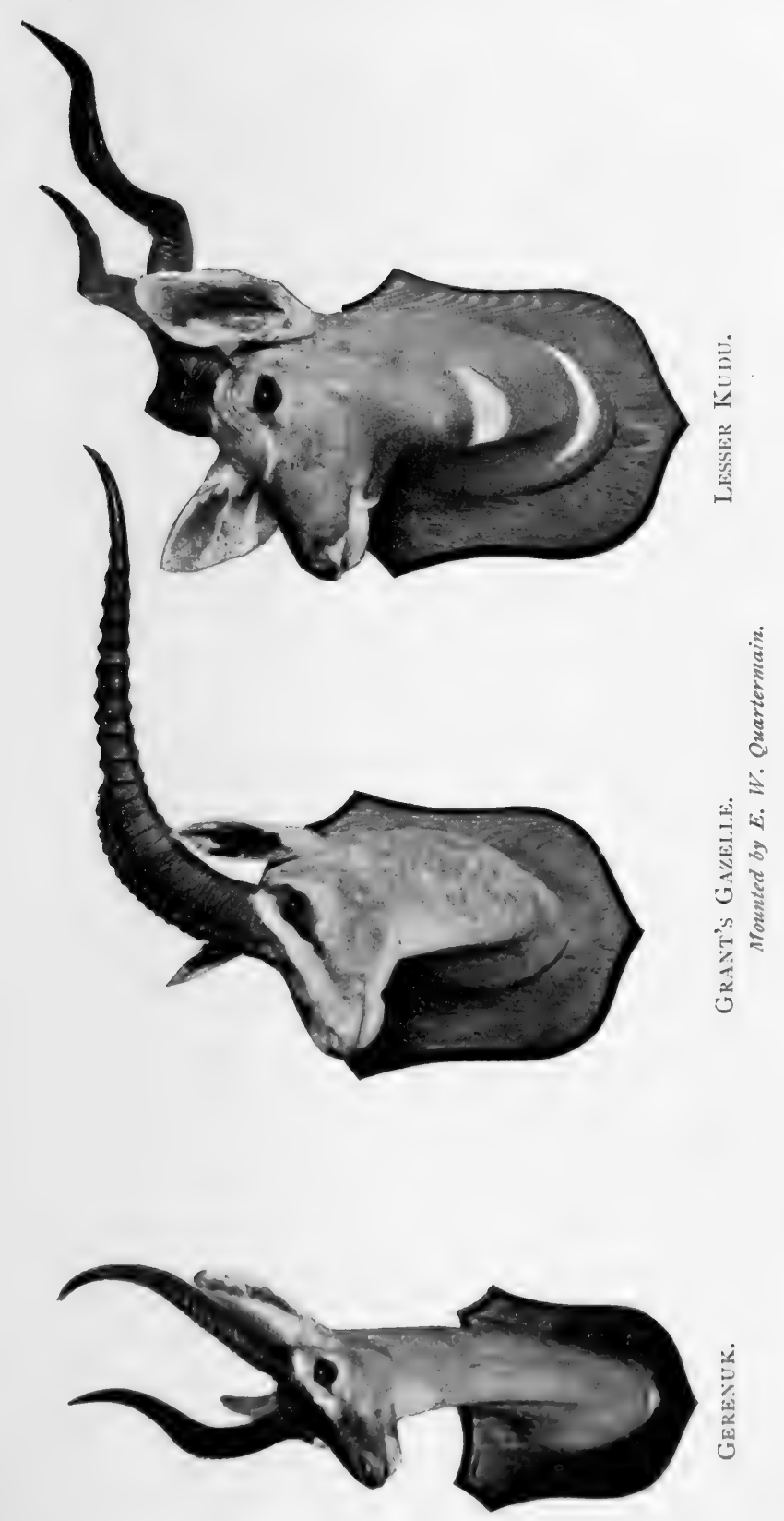

well to remember that a wounded buck has serviceable horns, and it is by no means loath to use them. The species is very widely distributed, but is especially numerous and fine-horned round the Mau and Kenya forests and in the gullies that intersect the Ithanga hills and the slopes of Ngong. They may be obtained with ease and certainty by driving, but stalking them round the edge of forest like roe-deer is to obtain the maximum of sport they can afford. Does and young bucks furnish about the best meat of any antelope.

The Lesser $K u d u$ gives a splendid excuse for an enjoyable outing. Nor need the sportsman go very far afield. Until the last four or five years his habitat was little known, and he was held to be a rare and notable prize. Luckily, investigation has proved the species to be both numerous and widely distributed. Unless very much disturbed, Lesser Kudu feed in the open till about nine or ten in the morning, coming out again after five. Between these hours it is quite useless to look for them. In hunting them the very greatest caution must be observed. If the hunter be observed before the hunted the result is a shrill whistle and the glimpse of a white scut. There is something especially fascinating about the chase of this animal. Not only is the trophy very beautiful, but its habitat is always wild, unpopulated country. The meat, which is rather tough, is said by some natives to produce stricture, a result which, I am glad to say, I have not experienced. A fine pair of horns would be anything over 30 inches round the curves, an average pair about 28 inches. The species exist in the following localities, the list being by no means comprehensive. M'toto Andei, Tsavo, Kenani and Voi, all on the railway line. The lower Tana, round 
Marsabit, along the German border. In all the bush country round Mumone. On the Serengati plains and round Taveta. The Shimba Hills. Parts of the coast and the Turkana country. It may be confidently looked for wherever sansiveria fibre abounds.

The Impala are beautiful animals which require extremely accurate stalking wherever they are at all molested. They do very little damage, and most settlers would welcome the presence of a herd, but somehow they do not seem to go well with civilisation and have a habit of disappearing. In places where they are little shot at they are occasionally extraordinarily tame, and those who only know them at such times look on them as the easiest of victims. The bucks often consort in parties of twenty or thirty, leaving the does accompanied by one or two bucks apart. It is hard to understand what qualities fit these latter for their onerous, if delightful, task. The bucks that run with the females are usually good, but not pre-eminent specimens. One can only guess that they are selected by the females for some qualities we wot not of. An impala is the best kill to leave out for a leopard. The size of horns vary very much in different localities. The largest specimens are found along the North Guaso Nyero towards the Lorian Swamp, where they have been known to run to over $3 \mathrm{I}$ inches. Anything over 27 inches is a good specimen. Anything over 29 inches a fine one. Impala are found along all decent streams, but must have shade during the heat of the day. It is seldom, if ever, found more than two miles from water.

I have included the Wart-hog in the list of sportproviding animals for the one reason that he can be speared. Indeed, he can give most excellent runs, 


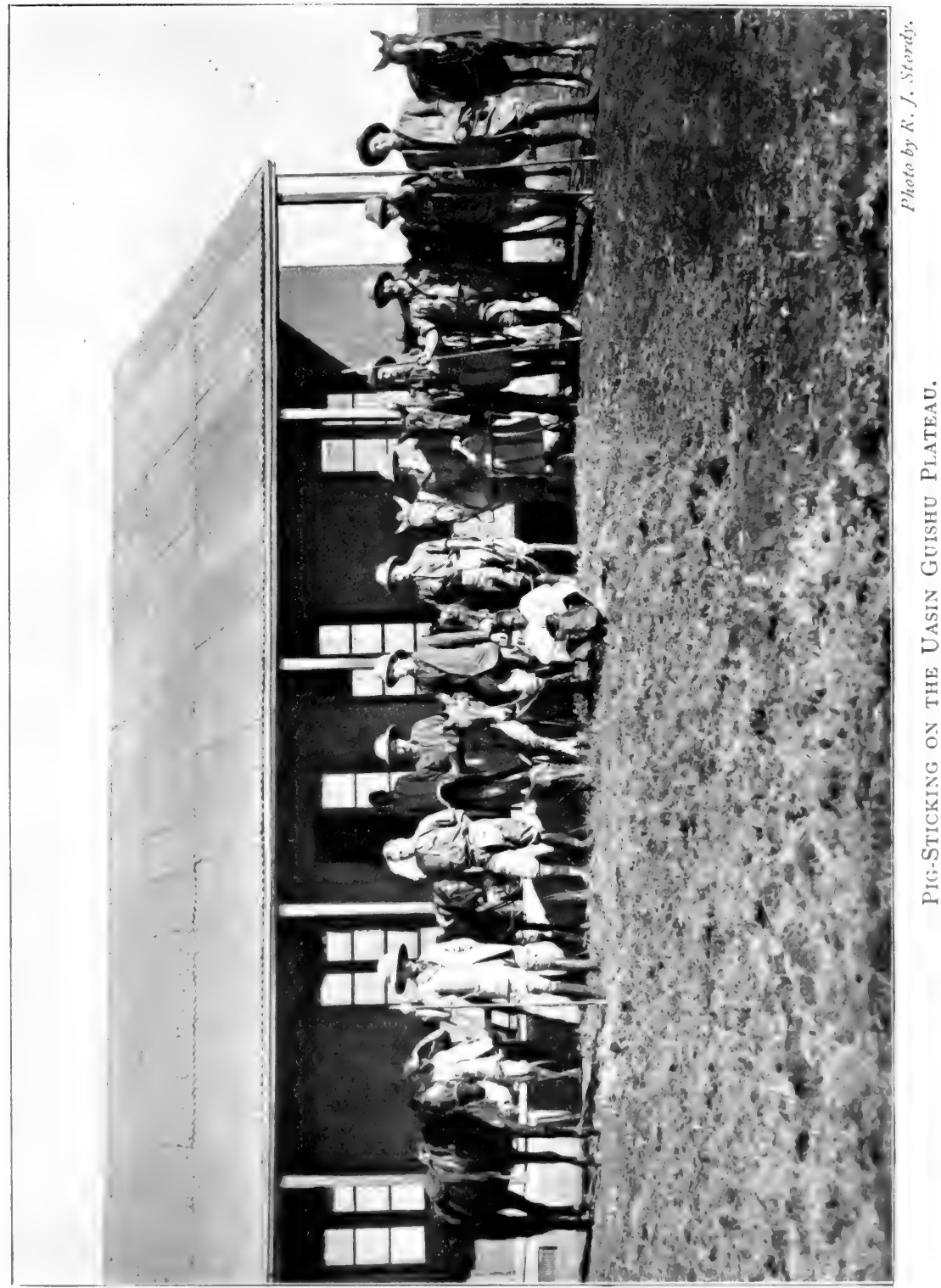



and also turn at bay to at least as good purpose as his cousin in India. There used to be a tent club in Nairobi, which has, unfortunately, lapsed for the present, chiefly, I think, because it became too expensive in ponies. Up at Njoro, Lord Delamere's estate, the sport used also to be indulged in, and another tent club has recently been formed on the Uasin Guishu Plateau. The Wart-hog is a fierce, determined animal, by no means belying his appearance. When it is borne in mind that a fine specimen has tusks 9 or 10 inches outside the mouth, it can be realised that he is no mean antagonist. $\mathrm{He}$ is rather a comic looking brute, and one of his curious habits is to enter the hole in which he spends the heat of the day hind legs first. Wart-hogs are well distributed throughout the Highlands, more especially on plains which are bordered by forest. They should provide much sport for future generations.

Chanler's Reedbuck, which are found on nearly every grassy hill of any size, provide pretty sport. They can be spied at a considerable distance and stalked. They are by no means confidential, and considerable pains must be taken to get within Ioo yards, as should be done. They are specially numerous on Ngong and through the Ithanga hills. A decent buck carries horns of between 6 and 7 inches.

The Klipspringer, the Duiker, the Sternbok, and the numerous species of Dik-diks provide sport in varying degrees. The Klipspringer is a very pretty little rock jumper. Wherever are found rocky, precipitous cliffs, he may be seen poised on the most perilous points, or leaping up or down seemingly impossible precipices. Like other rock jumpers the Klipspringer has an appreciation of his own hide, and 
as he is a small mark, forms rather a fascinating object to pursue. A point with regard to the species which has not been generally noted is that both male and female bear horns. In South Africa it is with rare exceptions only the males which are so distinguished. Duiker and steinbok are most mischievous little brutes, and for their size do more harm to young crops than any other animals, with the possible exception of baboons. Much, however, is forgiven them by the sporting farmer on account of the fine scent they provide. Both the Masara Hounds and several bobbery packs in various portions of the Highlands chase such small buck as an alternative to jackal, and of the two, most people hold that the former provide the better runs. It takes, however, a good pack, a good scent, and a long chase to pull one down. It is for this reason that I include what many might consider merely a nuisance in this list. The flesh of all small buck is excellent. Duiker especially make delightful pets, and run in and out of the house in the friendliest manner. It is almost impossible, however, to keep them away from rose buds. The leaves of rose bushes they are partial to, but the flower is their special delight, and they will bolt a full-blown rose like a pill. Harvey's Duiker, though somewhat local, is quite common in the Ngong forest and in any thick bush as far north as Kijabe. 


\section{CHAPTER XXVII}

ANIMALS WHICH PROVIDE MEAT OR HIDES

OF those animals to which the settler looks for meat or hides, rather than for sport, the Eland takes pride of place. This magnificent animal suffered almost as badly as did the buffalo in the rinderpest outbreak, and has made almost as satisfactory a recovery. $\mathrm{Mr}$. Edward North Buxton describes, in "Two African Trips," how he made great efforts, withoutavail, to obtain a trophy. Luckily, he would have no such difficulty now. The eland is the only antelope which carries fat, this being more especially the case with old bulls, which are sometimes very heavy. Such old fellows are extraordinarily easily galloped down, even by a slow pony. At a fast trot they are apparently able to go all day, but directly they are pressed into a gallop they begin to puff. On foot, however, it is no easy matter to stalk a bull, more especially if he has cows with him. Not only are the cows very vigilant, but the whole herd are nearly always on the move. Therefore, though not included as an animal likely to afford a settler with sport, he is not incapable of its production. I am far from being one of those who assert that there is no sport or skill in hunting on the plains, though I must confess that it is a sport apt to pall 
rather soon on all but the very keenest. No one who has seen that splendid sportsman, Mr. Jackson, stalking, or has known of what wonderful feats he has been capable, such as getting to within 30 yards of a Coke's hartebeeste on the plain, can doubt that skill, not to say endurance, of a very high order indeed is required.

Eland are both common nowadays and well distributed throughout the Highlands, though in 1909-10 there was a rather large mortality from gastro-enteritis, more especially towards the German border. They are numerous in both Game Reserves, on the Yatta plains, the Serengati plains, the Ithanga hills, all along the Tana and round Baringo. Old bulls are naturally less plentiful than a few years back; the Serengati plains probably alone hold big bulls in any large quantity. Eland run small in the Protectorate, comparatively speaking. A fine old bull in good condition might weigh I,600 lb. In South Africa he would weigh $2,000 \mathrm{lb}$. A fair bull would have 25 -inch horns. Anything over 27 inches would be very good. The oldest bulls have more massive but shorter horns, since in old age the points are almost invariably shortened by rubbing. An attempt has been made to establish a sub-species (pattersonii) of the northern individuals. Such subdivision is very far-fetched. Eland are migratory, and, in fact, always changing their ground. Thus, although, as I have said, they are very common, I know of no farm where a herd is domiciled. If news of eland is brought in one evening, their whereabouts on the morrow is quite uncertain; it is, however, certain that it will be many miles distant. Settlers have always looked with a kindly eye on the eland, the Rift Valley farmers, a most 


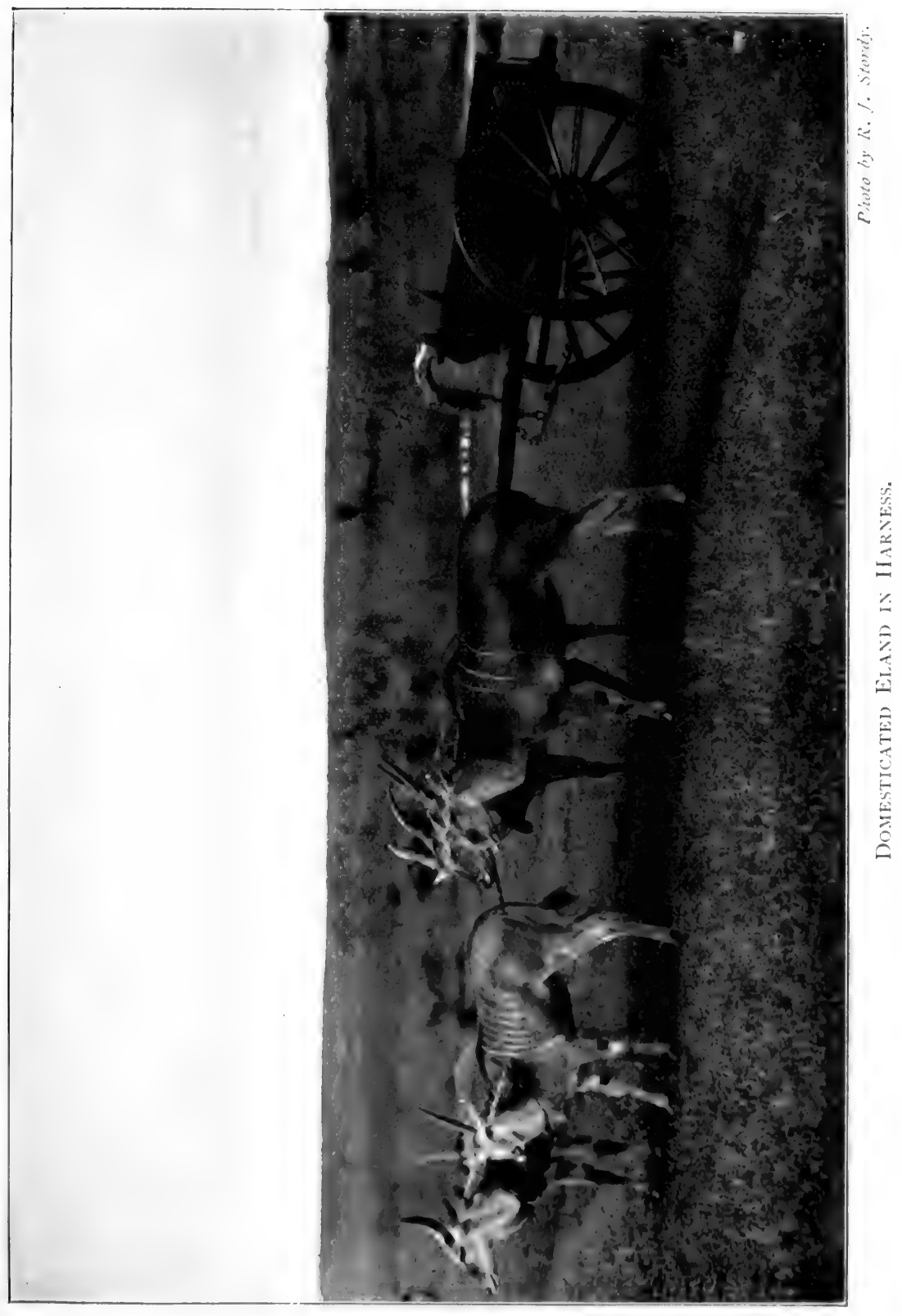



sporting lot, having even prohibited his slaughter in their neighbourhood. Attempts have been made, with moderate success, to utilise his great strength for transport, under the idea, sound in itself, that the domesticity of the eland might solve the problem of such work in tsetse-fly districts. It is to be feared that the experiment is likely to be more expensive than useful.

Waterbuck in British East Africa are of two kinds, Ellipsiprymnus and Defassa. Though the difference between the two is not very great, it is quite distinct, and as far as I know there is no recorded instance of the two species intermingling or interbreeding. The Defassa is somewhat larger, of a redder colour, and has a whole white rump, while that of the Ellipsiprymnus has an elliptical white marking. Roughly speaking, it may be said that to the east of the Kikuyu escarpment is the habitat of the Ellipsiprymnus, to the west of the Defassa. In the eyes of settlers the waterbuck's merits consist of his beauty and the toughness of his hide; the latter provides the strongest and best "reims" of any antelope. To my mind, with the possible and doubtful exception of the Greater Kudu, the waterbuck is the most handsome of all our bucks ; and unlike the kudu, the waterbuck is by no means averse to displaying his charms. His gait and carriage are singularly stag-like and majestic, and the sight of a herd of, say, a dozen does and two fine bulls amidst a grove of sweet-smelling mimosa trees fringing a stream, cannot fail to thrill the onlooker with an intense pleasure. There is, unfortunately, a great diminution of shootable bulls in the Protectorate, due doubtless to the fact that, not only is the trophy exceedingly handsome, but it is very easily obtained. 
Consequently, nowadays huge bands of does are seen in company with a half-grown bull or two. It is possible that the number allowed to be shot on a licence might be reduced, and farmers who appreciate the presence of this very harmless antelope would be well advised to obtain their " reims" from old does in preference to bulls in the prime of life. Waterbuck meat is so exceptionally nasty that porters have been known to refrain from eating more than a certain amount, and actually not to finish the entire carcase, incredible as it may sound. A fair pair of Ellipsiprymnus horns would be 25 inches, and 27 inches might be considered fine. In Defassa the similar measurements might be 27 inches and 29 inches. In Uganda, of course, specimens run very much bigger. Nearly all streams and lakes with wooded banks have waterbuck within two miles. They used to be especially numerous and fine on the Uasin Guishu plateau, but the Dutch population have altered all that and have exterminated or driven across the Nzoia the great majority.

The Wildebeeste or White-bearded Brindled Gnu has a useful hide and furnishes fairly savoury meat, the tongue and tail being the best portions. Now that the Loieta plains have become a portion of the Masai Reserve, comparatively few farmers are in direct contact with the animal. Such would be those who are resident on or adjoin the Athi or Kapiti plains. There are, moreover, two domiciled or resident herds, one on Mr. McMillan's farm and the other on that of Messrs. D. Seth Smith and M. Ridley. These two herds have remained on the same ground for many years though the old bulls are systematically and regularly shot. Their numbers are inclined to increase and they 
certainly refute the argument that the periodical migration is necessary for the preservation of the species. Wildebeeste used to be excessively numerous in certain seasons on the Athi plains. Mr. Buxton saw in 1900 a herd some miles long and containing many thousands. Now there are but a few hundred. It is difficult to know what has happened to them. They have not suffered from disease, and have certainly not been shot in our territory. It is to be hoped, though one cannot be very sanguine, that they have merely retired into the back regions of German East Africa. The horns are measured in the same way as buffalo; a fair specimen would measure in this way 27 inches and a fine one 29 inches. In addition to the localities already mentioned there are a good many wildebeeste on the Loieta plains and beyond to the German border ; also on the Kapiti plains and at Simba.

The Hartebeeste (Coke's, Jackson's and Neumann's) is ubiquitous and is generally held in such detestation that one must feel very doubtful of putting him in this category as being of any use to the average settler. $\mathrm{My}$ reason for doing so is the consideration that without his carcase a large proportion of settlers would so very frequently have gone hungry. Also his hide is undoubtedly tough and useful. Coke's hartebeeste is the variety that occurs south and east of the Rift valley. It is considerably smaller than Jackson's, weighing about $300 \mathrm{lb}$. as against more than $400 \mathrm{lb}$., and is also of a lighter shade of khaki. Jackson's is found north and west of the Rift valley. Neumann's is a very local and intermediate variety, and no doubt originated by the interbreeding of the two distinct species. It occurs around Lake Solai, and in size, colour, and shape of horns divides the characteristics 
CHAP.

of Coke's and Jackson's. The one quality that distinguishes the appearance of all varieties of hartebeeste is a look of almost preternatural stupidity, an appearance to which his every action gives the lie direct. Nearly every newcomer says to himself as he takes his new rifle from its case: "I will go and shoot a couple of those foolish-looking animals which are lolling about some 400 or 500 yards distant from the camp. The meat will be useful, and I want to try a couple of shots from this gun." He strolls off, intending to walk within I5O yards, sit down and bag his brace. As he strolls in their direction they stroll off at the same pace. The novice then gets down on his stomach and taking advantage of every blade of cover, as he thinks, crawls perspiring but triumphant to an ant-hill which he has marked as being well within range of the herd. Cautiously he lifts his head to choose his unsuspecting victim at Ioo yards. Instead he sees at the same unvarying distance of some 500 yards the whole herd gazing fixedly in his direction. It ends by the angry and fruitless emptying of his magazine and the return to camp of a tired, angry, but wiser individual. At 500 yards' distance the herd resume grazing. At one time only is it possible, and indeed more than possible, to get within 50 yards of one of these foolish-looking animals. When some nobler quarry, such as an eland, is being stalked, one or more hartebeeste will cross the plain and plant themselves some 40 yards or so from the stalker, to whom they will shout opprobrious remarks, at the same time warning the eland of the approach of danger. In speed he is equally deceptive. Ungainly, not to say clumsy, in gait, he is fleet and untirable. Indeed, when the American lassooer, Mr. 
"Buffalo" Jones, came to the Protectorate with a novel method of slaughtering its inhabitants, I believe that the "Kongoni" alone proved absolutely beyond his powers to capture. There can be no question as to the destructive powers and propensities of this beast. In huge herds he breaks fences and ravages crops, thereby winning for himself no slight measure of opprobrium. Everyone's hand is against him, and on the occupied portions of the Protectorate he is fast decreasing. Yet the first comer and those who even now live on the outskirts of civilisation should and generally do remember the stomachs that have been filled, and the traces and shafts that have been mended through the agency of the despised "Kongoni." An average pair of Coke's hartebeeste horns measure about 19 inches on the front curve, and generally speaking every big game shooter breaks the recorded record, which gives pleasure to him and does no harm to anyone. An average pair belonging to a Jackson bull would be 23 inches, and 25 inches would be unusually large. Neumann's variety might measure 22 inches.

The Topi, in certain parts of the Protectorate, takes the place of the hartebeeste, to which species he is allied. A much more handsome animal, with his dark chestnut coat, and more compact and neat head, he possesses many of the same characteristics, and has the same propensities for evil. In those parts of the Highlands already in white occupation he is only found in the neighbourhood of Londiani and round Muhoroni. Elsewhere topi are very plentiful in Jubaland, east and north of Lake Rudolf, and from the Loieta plains to the German frontier. A good pair of horns would measure 19 inches. 
Grant's Gazelle and its various sub-species have provided the settler with many a dinner, while as its horns are extremely handsome and more easily obtained than those of any other animal they form an adornment on the walls of most farms. This gazelle varies slightly in different portions of the Protectorate in the prominence or otherwise of the dark bands which mark its flanks, and considerably in the shape and size of horns, and at least four sub-species have been enumerated. Thus (a) Gazella granti typica as found on the Athi, Kapiti and Serengati plains, has practically no flank markings when adult. The horns are long and lyrate, but the spread between the horns seldom exceeds $\mathrm{I} 4$ inches. A big ram weighs $\mathrm{I} 60 \mathrm{lb}$. (b) Going south-west from the Kedong valley, the flank marks remain invisible, but the spread of the horns increases markedly and very greatly even up to 27 inches or 28 inches. The gazelle grows very large here up to at least I $70 \mathrm{lb}$. Here a sub-species has been named Robertsi. (c) Going north to Likipia and round Lake Baringo, the dark flank bands become prominent, and the horns run close together. The animal itself also is small, a full-grown ram not exceeding I $25 \mathrm{lb}$. A sub-species is formed here and termed Gazella granti notata. (d) Proceeding northwards again into the Northern Game Reserve and right on the border and into Abyssinian Boran, we find further differences. The animal becomes bigger again, up to 140 lb. A large white patch runs from the rump on to the back, and there are very marked hairy tufts on the knees. The face markings are also very distinct and the horns more massive than anywhere else. This is, I believe, the animal that Mr. Stigand terms the Haul and may possibly be what is known as Gazella 
granti brightii, though I rather fancy that that is another name for the notata. All these variations run into each other and merge so gradually that he would be a wise man indeed who could lay down any sharp subdivision. In the south of the Protectorate the gazelle hardly ever leaves the plains, but the northern varieties are often found in scattered bush. $\mathrm{He}$ is a confidential beast, and may be shot at and missed, followed and missed again, till he eventually succumbs, in this characteristic resembling the jack snipe. The meat is good, but it is just as well to refuse the liver, as it is more often than not infested by worms. A fair head of Granti typica or Robertsi would be 26 inches, though I have measured one of the former $3 \mathrm{I} \frac{1}{2}$ inches. The northern varieties run about 23 inches, the "haul" perhaps an inch longer.

Thomson's Gazelle forms the farmer's tit-bit, his flesh being the most succulent of any antelope. Tommies, as they are usually termed, are, however, unfortunately very destructive to young crops, more especially young wheat, and this bump of destructiveness is leading to their very rapid reduction. Thus round the shores of Lake Naivasha there used to be many thousands, now it is doubtful if there are as many hundreds. Thomson's gazelle are widely distributed throughout the plains of the Highlands wherever there is decent grazing of short, sweet grass. They are not found where the grass is very long and rank, nor yet in dry barren regions far from water, where some form of Grant's gazelle is almost certain to exist. An average weight of a ram would be $55 \mathrm{lb}$., but, curiously, they increase in stature and attain at least $70 \mathrm{lb}$. around and north of Rumuruti, at which spot Grant's gazelle achieve their smallest development. In the same 
district, Thomson's gazelle grows horns up to i6 inches, at least an inch longer than is attained further south. On one day they will prove quite tame and easily approached, while the next they may be most elusive.

All the lesser buck provide good eating, and the varieties to which the settler will help himself in different localities are duiker, steinbok, Kirk's dik-dik, common oribi-especially numerous near Londiani and on the Uasin Guishu plateau-and the Kenia oribi, which last, extremely local, is getting very scarce. 


\section{CHAPTER XXVIII}

THE BLACK LIST

THERE remains another category of animals with which the settler is only too well acquainted. This list comprises those which have much to condemn them, but provide nothing through which these disadvantages may be counterbalanced. As a lover of animals it has been my aim to make this list as short as possible, and animals have been included in worthier lists which would by the majority of settlers have been placed in this, the Black List.

Of all the suspects, least can be urged in favour of the Rhinoceros. It is to be feared that, from a settler's point of view, he has nothing whatever to recommend him. He is destructive, and no fence has yet been erected which will withstand his onslaught. He offers no kind of sport whatever himself, and at the same time may be a very considerable nuisance when the pursuit of some worthier trophy is in process. His hide, it is true, makes excellent riding whips and most odoriferous table-tops, but his whole skin is usually too bulky to be removed, and one could hardly shoot such an enormous brute for the sake of half-a-dozen riding whips. As to the comestible properties of his flesh, it can only be said, as Nebuchadnezzar, when on 
a grass diet, is reported to have remarked, "on tasting the unwonted food: 'it may be eaten, but it isn't good.'" The only real use of the rhino is to provide thrills for big-game hunters and episodes with which to harrow the feelings and compel the admiration of friends in England. It is the very rarest of exceptions for a "safari" to return from a shooting expedition without a rhinoceros having provided a hairbreadth escape to some member of the party, black or white. It may be of some consolation to the intending voyager to know that the breadth of the hair will practically always be on the right side. During all the years of big-game shooting in British East Africa, and after all the many hundreds of specimens which have been slain-707 were accounted for in I9 Io and I9I I alone-the fatal or even serious accidents can be counted on the fingers of one hand. The rhinoceros is large, the rhinoceros is blind, he looks very fierce, and he has got to go somewhere when disturbed, which, like most animals, is almost invariably up wind. The consequence of these facts is that a horrid great monster, sleeping under a tree, gets the wind of a caravan and naturally rushes up wind towards and through it, and no one can deny that he looks most objectionable. As a proof, however, that he is not really vicious lies the fact that it is the rarest of occasions on which he retraces his steps; almost invariably his initial rush goes straight on. $\mathrm{Mr}$. Stigand, in a very carefully reasoned argument, comes to the conclusion that one in every 250 rhino charges with vicious intent. In common with everyone who has passed much time travelling about the Protectorate, I have seen a good many hundred rhinosceros, but only once have I seen a rhino-or in this case a pair of them- 
who showed an apparent wish for my extermination. This was in the Southern Game Reserve, and after the pair had made three charges at increasing proximity, I thought it advisable to conclude my observations from the branches of an exceedingly thorny tree. The wind at the time was very shifty and my opinion is that it was uncertainty as to the safest mode of escape that influenced their actions. However, I most certainly felt that a tree, even a thorny one, was to be preferred to the ground. The conduct of the animal when disturbed is one over which every sportsman can dogmatise to his heart's content. As Mr. Dugmore in his excellent book points out, one is too much inclined to judge by personal experience. One man comes out, sees half-a-dozen rhinos, shoots two, and says that they are quite tame and easily obtainable. His friend comes next season, sees three or four, of which a couple run through his caravan and one puts his foot through his camera. He doesn't shoot a specimen. This man reports that they are very vicious, and not too easy to obtain. I hold one belief, possibly rather far-fetched, that certain sportsmen, greatly affected by exertion in the sun, give out a considerably more pungent odour than others, and that this odour invites a determined charge. In short, that those who sweat the most are charged the most. One thing is absolutely certain, and that is that the species is a nuisance to the sportsman and impossible to the farmer. A kudu or buffalo is being pursued through thick bush; suddenly there is a horrid snort, and a huge dark body bursts through the trees and dashes by in a manner which is ruin to the nerve and to the steady hand. This is bad enough, but if the animal's course be directed towards one's 'shamba' it is 
worse! Luckily, they are not slow to take the hint that their room is preferable to their company, and are very easily banished. Thus practically all the open plain in the Highlands used to be infested with rhino, and notably all the open country round Nairobi. Nowadays it is quite the exception to come across rhino in the open, though the surrounding bushland may be full of them. Rhino are usually found singly, in which case it is probably a bull ; or in pairs, in which case they are generally a cow and calf ; or in threes, a bull, a cow, and a calf. Larger parties are sometimes seen, but I cannot personally recall more than five standing together. Their favourite food is young mimosa thorn coming up in the grass, or boughs taken from trees of the same variety. They do not care for grass, of which they eat but little. Those who aver that they have seen rhinoceros browsing vigorously off grass on the plain would very often find on examination that it is the young thorns amongst the grass that have suffered. The mother suckles its young for three years, and one can accordingly understand how long-lived and therefore easily exterminated the race is. To the great satisfaction of all concerned, each year sees less rhinoceros on the more traversed routes. There need be no fear whatever for his absolute extermination, as there are large tracts of forest and almost impenetrable bush in which he can exist and where to hunt him will be a sport dangerous and genuine enough for anyone. Large horns are very rare nowadays, or at all events hard to obtain. The longest are nearly always possessed by cows, those of the males being the more massive. Outside thick cover it is to-day hard to obtain a horn of more than 22 or 23 inches. 
Rhino are especially numerous in the following localities : round Lake Marsabit, the Yatta plains, the northern Guaso Nyero, the South Guaso Nyero, the Tana and Thika rivers, especially towards the junction of the two; in this neighbourhood a few years back I counted sixty in one day, the Tsavo river, and all bush country where there is any water, more especially the large tract lying between Kitui and the lower waters of the Tana, the Ithanga hills, and the country all round Lake Baringo. There remains one female with an exceptionally long horn, at least 36 inches, in the Ngong forest.

Next to the rhinoceros the common Zebra is the most unmitigated pest to farmers in the Protectorate. $\mathrm{He}$ is almost ubiquitous throughout the Highlands, and is found, not only on the plain, but through the bush and even on hills of considerable height. Zebra nearly always congregate in herds, which herds constitute the favourite prey of the lion. Most travellers through the country know the zebra's note of alarm, like the bark of a terrier dog, followed by the clatter of a hundred hoofs which tells of the stampede of a herd from a real or imagined attack. It is these stampedes that no ordinary fence can withstand and which render the presence of zebra so absolutely fatal in the proximity of agriculture. The beast, moreover, has no advantages to compensate ever so slightly for the damage he inflicts. The meat has the same nasty sweet taste as horse, and one must be hungry indeed to eat it with any relish. Natives, however, prefer it to any other and it enables them to perform astonishing digestive feats. Also those who should know say that pigs will eat it with avidity. The hide is soft and of little local value. It is sometimes used for the backs 
and seat of chairs, and when so prepared may be given with a sense of pleasure to one's best enemy on his marriage. Several attempts have been made and a good deal of money-most of it, luckily, Germanexpended with the object of breaking in zebra as beasts of burden. Such attempts have all ended in failure; chiefly owing to the lack of heart shown by the animal; the moment the work goes at all against the collar it is chucked. $\mathrm{He}$ is also savage as well as delicate in captivity. In German East Africa attempts have also been made to cross zebra with a stallion. The result, a zebroid, is a beautiful and more satisfactory animal, but the proceeding is hardly likely to prove a commercial success. Zebra are showing a marked and satisfactory decrease throughout the inhabited portions of the Highlands.

Hippopotamus should be really included in this class, because while he provides nothing useful or sporting, he is absolutely ruinous to any cultivation. At the present moment there is very little European agricultural farming near his haunts, but as soon as that time comes the "hippo" in the vicinity will be given short shrift. $\mathrm{He}$ is, of course, no danger to stock farmers, and being a most interesting and inoffensive beast will be probably preserved in streams and lakes in their neighbourhood. Thus the farmers round Lake Naivasha preserve the species there, where he is a most peaceable inmate for the most part, though capable of having a disturbing influence on a boating party. The finest specimens are found in Lake Victoria or in the Tana, but most rivers or lakes of any size contain hippo in greater or smaller quantities. Among such, I recall the Naivasha, Nakuru and Rudolf 


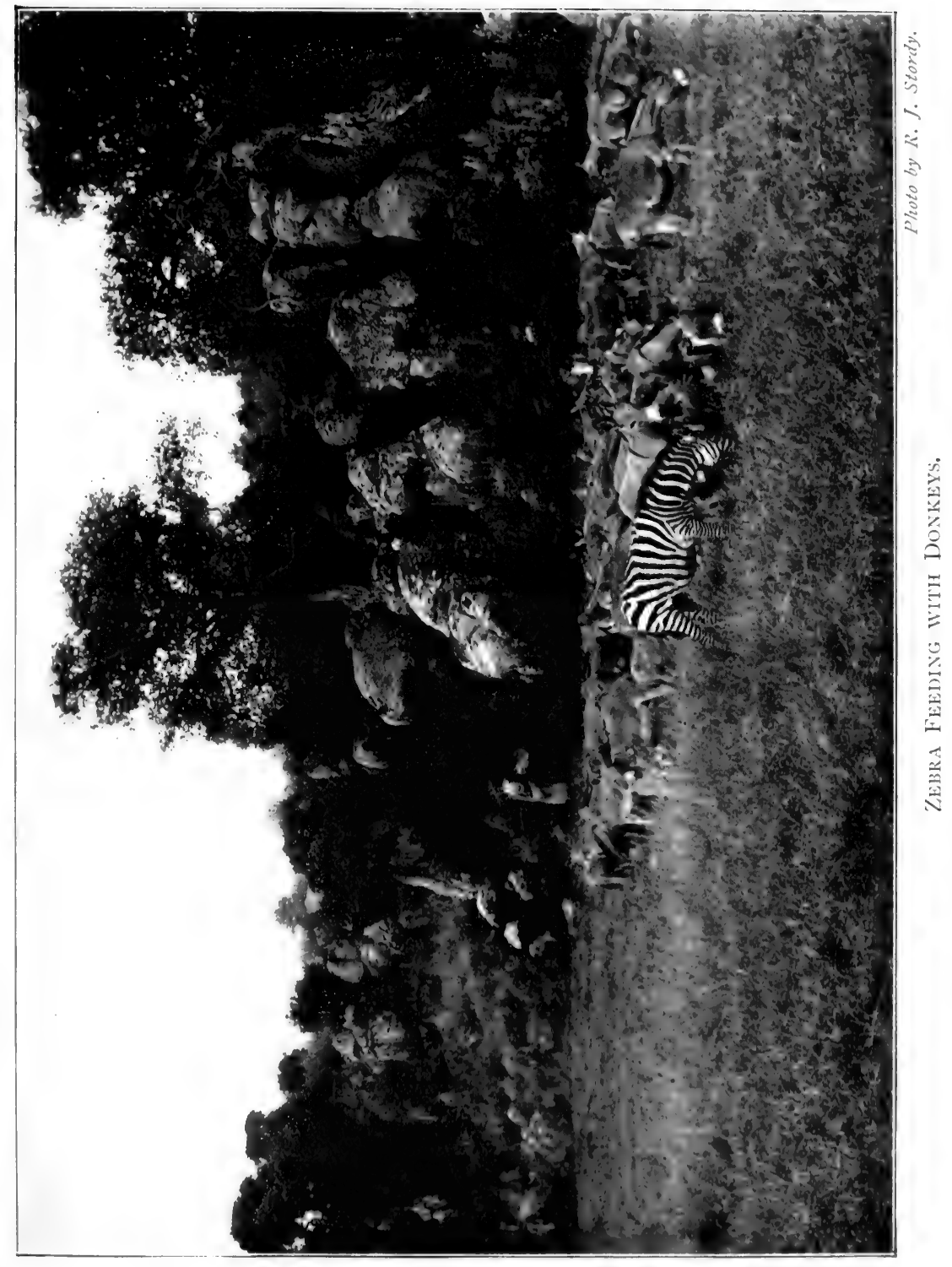



lakes, the Thika, the Athi and Tana rivers, the Lorian, Olbolossat and other big swamps.

The Baboon should be destroyed or driven away wherever he exists. Not only does he destroy gardens, fruit trees, and "shambas," but he has a horrid partiality for young lambs. The latter he kills more for the pleasure of killing than to eat, his method being to rip the bowels open with the thumb. I have not heard as yet of much damage inflicted in the Protectorate, but South Africa has experienced the same in abundance. A big male baboon is an awkward looking customer and a match for any dog. They appear to have little respect for man, and there are tales of attacks on women and children, but I do not know of any authenticated instances.

The Bush-pig completes a list drawn to its smallest confines. He is a nocturnal feeder and therefore comparatively seldom seen, but for all that is common all round the edge of forest and where there is any thick cover. The great and outstanding crime of the bushpig lies in the fact that he is, almost without the shadow of a doubt, the carrier of swine-fever, and therefore most inimicable to all pig breeders. $\mathrm{He}$ is also destructive to farms and gardens, and no means can be too drastic for his destruction. Young bush-pig are fairly toothsome. 


\section{CHAPTER XXIX}

\section{ANIMALS OF THE BACK BLOCKS}

WE come finally to the category of those animals with which the ordinary settler, or farmer, but rarely comes into direct contact. He cannot fail, however, to hear of many of them from big game shooters and others, and it is not improbable that he may, either during leave or on some trading or cattle-buying expedition, have opportunities of obtaining a specimen of many of the more interesting species. On this account, therefore, a brief notice of the chief varieties is here appended.

The Elephant formed at one time the main source from which the early pioneers could refill their defleted coffers. When most other more legitimate enterprises were experimental, the elephant was in a position to supply in person or through the teeth of his ancestors the sinews of war for such experiments. Until the advent of the railway and all that it stood for-such as game licences, fines and export duties-large herds of elephants containing many magnificent tuskers roamed through the forests and bush and over the plains of the Highlands and were plentiful round Nairobi and in the Ngong forest. Nowadays, the numbers are hardly if

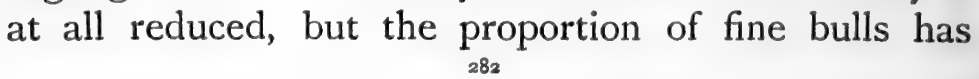




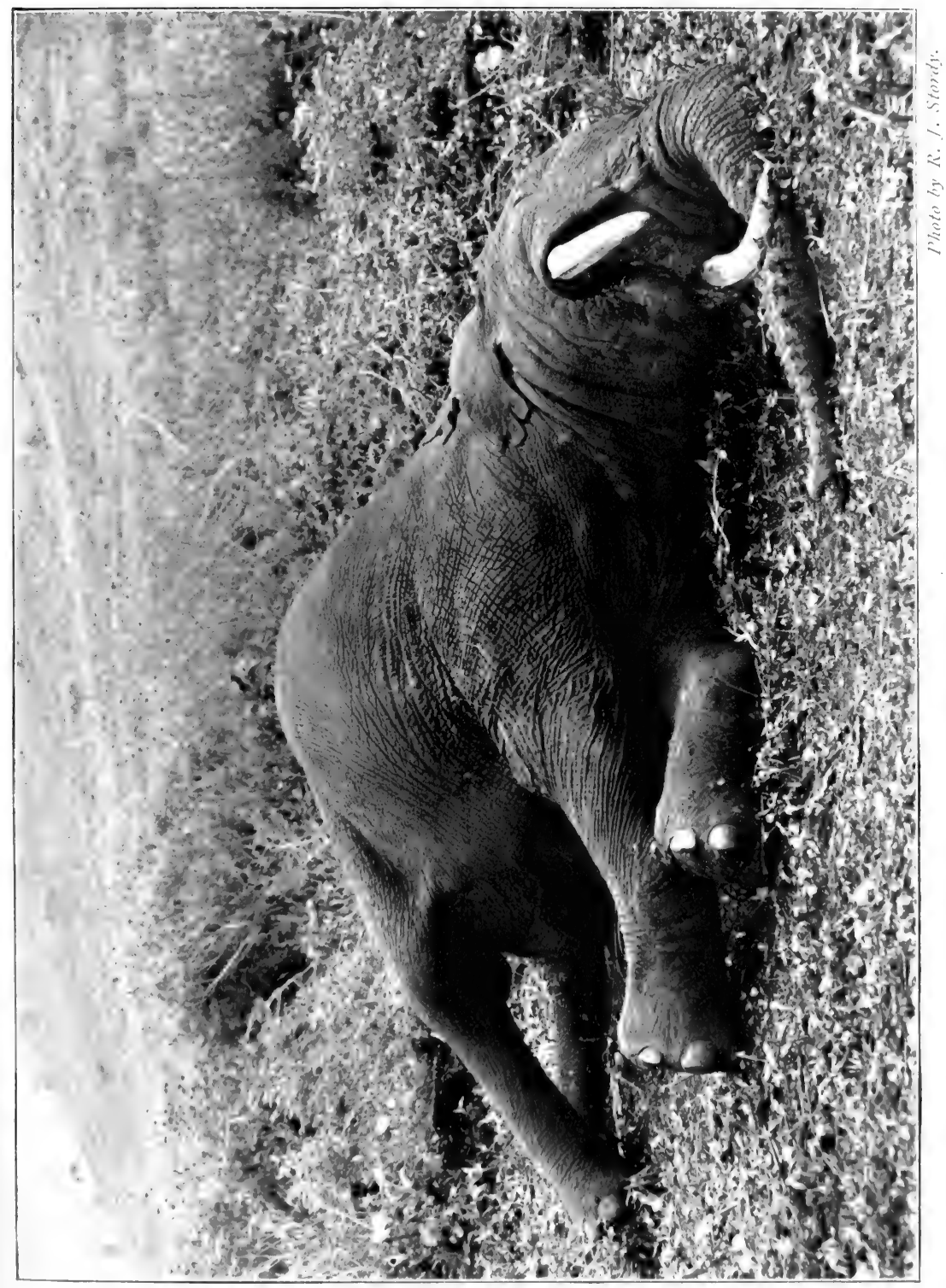


$\therefore$

$\therefore \quad \%$

. 40 
decreased to a minimum; further, it is only in the more remote corners of the Protectorate that elephant can be found elsewhere than in thick bush or in forest. Again, many of the herds of cows, having been much persecuted, are getting exceeding savage and prone to charge at sight or rather at scent. All these reasons combine to prevent its being worth the settler's while, except in rare instances, to take out a licence with the view of getting a little surplus cash. There can, I think, be little doubt nowadays as to the danger of elephant shooting, and none as to its excitement. Both elements are greatly increased in the Protectorate since the days of that great hunter, the late Mr. Neumann. In his day, the unprovoked attack of a herd was practically unknown, and also nearly all the shooting was done in fairly open country. Thus Neumann says that he has never known a charging elephant which would not turn if a bullet was placed in its chest-though it must be borne in mind that he himself was nearly killed by the charge of a wounded cow. Also that after a day or two of hunting in the bamboo forests of Kenia nothing on earth would induce him to do so again. The most desirable place to encounter elephants would be open forest with big trees and little undergrowth. After that, open plain. Next, thin bush. Last of all would be selected elephant grass, thick thorn bush and bamboo. Elephant hunting is a sport which involves the necessity of a cool head coupled with great activity and endurance, and is held by some, such as Stigand, to be the finest of all African hunting. There is no doubt in my own mind that it is the hardest and most dangerous form, but possibly it requires less of that desirable element which 
consists in matching the intelligence and knowledge of the hunter against the instinct and cunning of the quarry. No very great quantity of elephants are killed nowadays in the Protectorate-in I9IO and I9I I it was forty-six-but nearly all these are old bulls. Indeed the real veterans are by now mainly exterminated, and hunters are turning their attention to the breeding bulls. It is as hard to-day to get a $70 \mathrm{lb}$. tusker as three or four years back it was to get a hundred pounder. In view of the huge herds of cows which exist, it is a question whether, instead of the second bull, two cows might not be placed on the licence.

In addition to those animals killed and accounted for on licence, the elephant has the following enemies to contend with in the Protectorate. The Wandorobo and Wakamba hunter kill a small and decreasing number yearly; Somalis kill all that they can in the neighbourhood of the Lorian swamp; Abyssinian hunters from over the border make periodical and at times very destructive raids into our territory. Indian traders are always ready to buy undersized bull and cow ivory and to ask no questions. It is satisfactory to know that on all these depredations the Game Department is keeping a vigilant eye.

Herds of elephant are found in the following localities among others-it being borne in mind that they are by nature very migratory: The Mau forest, Kenia forest, the Aberdares and especially round Thompson's Falls, Lake Marsabit and its neighbourhood, where there are hundreds of cows, but very few bulls; Mohoroni and Kisii, where the cows are apt to charge at sight; the lower waters of the Tana and all 
the thick bush country up to Kitui ; the slopes of Elgon and the trans-Nzoia country, where again they consist mostly of cows ; the thick bush round the Tsavo river, where there are some good bulls existent ; the Mumoni Hills, the Lorian swamp, both Game Reserves, though much more numerous in the northern, near and about Lake Rudolf, and in the thorn scrub of the neighbourhood, at certain seasons, between Mombasa and Malindi.

The best shots are the brain shot, at a spot between the eye and ear-hole, and naturally varying and becoming lower as the beast is more closely approached, and the heart shot, at a spot behind and beneath the shoulder, approximately where the lowest point of the ear would come if lain back and against the side. The heart comes very low down, and the shooter is unlikely to aim below it. On the whole most of the more experienced hunters prefer the latter if they have a choice. The heart is much the larger mark, being roughly about the size of a stable bucket, and there is also an excellent chance of missing the heart and piercing the lungs. A head shot, if not immediately fatal, does no harm whatever. Occasionally a leg shot or one at the backbone may be useful in disabling a wounded animal.

The Bongo is one of those elusive forest animals which for so long baffled the skill and energy of our best hunters. Very large in bulk-being exceeded therein among antelopes only by the eland, and possibly by the kudu-and comparatively common, it was only in recent times that his presence and locality were definitely ascertained. Mr. F. J. Jackson, for instance, though for many years aware of its existence, spent long and arduous hunts with- 
out actually, in person, securing a specimen, and where he failed it is natural that failure was general. The existence of the species was established by skins and horns brought in by native hunters (Wanderobo), but no European secured a specimen until that fine hunter, Mr. Stigand, killed a young bull, and since then not half-a-dozen Europeans have obtained one. Nor can any hunter yet claim a trophy through his own unaided efforts. Of those who have studied the habits of the bongo, Lord Delamere and Mr. Berkeley Cole, whose estates adjoin a portion of the Mau forest, have the best first-hand information. During the bulk of the year the bongo lies hid in the huge patches of bamboo that occur above a certain elevation. When, however, the rainy season occurs, and the forest is also more quiet, they descend lower down the spurs. At such times they will feed up to 9 a.m. right down to the verge of the forest, retiring after that hour to the most impenetrable jungle they can find, in which they lie perfectly safe during the heat of the day. They must, therefore, in all probability, be shot quite early if they are to be obtained. The only successful method so far has been to get on fresh tracks at daybreak and to follow them up in the hope of coming on the animal before he returns to rest. In the soft earth in the forest the track is easy to follow ; but the best white hunter in the world would be forced to acquire the services of a native guide, since to retrace one's steps and to emerge from the dense thicket is a matter of extreme difficulty and accurate knowledge; so difficult indeed that the Wandorobo, who have an almost uncanny prescience of direction, admit that they each know but a very small segment of forest. 
The bongo is in certain localities quite common, and if the ground is undisturbed the probability is in favour of getting on fresh spoor within an hour. When Mr. Roosevelt and his son Kermit visited British East Africa the best ground was especially rested for their benefit, with the result that bongo were quite numerous therein. Mr. Kermit Roosevelt was led up at once to two good bulls, which, unfortunately, eluded his eyesight in the open jungle, where their colouring is most distinctly protective. Proceeding further, a herd numbering at least thirty or forty were encountered ; the sight of so many of such a rare species grouped in his proximity not unnaturally so excited the young sportsman that his shooting became somewhat erratic. Luckily, the bongo shared his bewilderment, and remained until he eventually obtained a cow and calf, prizes which he richly deserved, if only for the earnestness with which, after his first failure, he had gone in pursuit. Lord Delamere, one of the keenest of observers, had hoped that he had devised a scheme whereby the ex-President might be equally successful. Colonel Roosevelt's bulk and conversational powers somewhat precluded him from tracking, since the utmost caution and lack of noise are essential. Lord Delamere, however, found that, where a deep stream flowed down the hillside, there were only certain passages which the bongo, when alarmed, would take. Selecting such a spot with three "passes," he placed Mr. Roosevelt in the most likely crossing, stood himself in another, and stationed a native armed with a bow to turn the bongo back if he came to the third, and most unlikely, pass. Beaters were then sent some miles round. Alas! two fine bulls came to the crossing at which the 
bowman stood, passing within two yards of him! The British East African bongo carries horns in both sexes, the male, of course, having much the more massive and handsome. Any bongo may be shot, but over 30 inches would be a nice bull. Although not often seen, bongo undoubtedly do cross open glades; I have seen their fresh tracks over an opening for at least a mile. Natives often obtain specimens with packs of dogs, which follow the game, bay it, and hold it up till despatched with spears and arrows. European dogs, however, tend to become awed and demoralised by the huge size, silence, and loneliness of the forest, and after the first day or so will not hunt. I am at a loss to understand why, for so long, the Game Department have winked at the sale by natives of skins and horns belonging to this magnificent and harmless antelope. $\mathrm{He}$ is found only in the thickest forest and is reported from several localities. I have only myself seen his spoor or heard definite report of his capture from the Mau forest, the Aberdares, and the Kenia forest.

The Greater Kudu, unluckily for himself, is provided by nature with the finest horns of any known antelope ; luckily, she has also provided him with a due sense of their value, and no beast takes greater care of himself. Thus, although the species is fairly widely distributed, and probably much more common than is generally supposed, very few specimens are killed annually. Unfortunately, Kudu of both species seem very liable to disease; during the last ten years there have been at least two outbreaks of gastro-enteritis or some similar disease, which have severely affected all the known herds in the Protectorate. From his size, stately bearing, and the magnificence of his horns, one imagines the Kudu as lording it among glades and park-like 


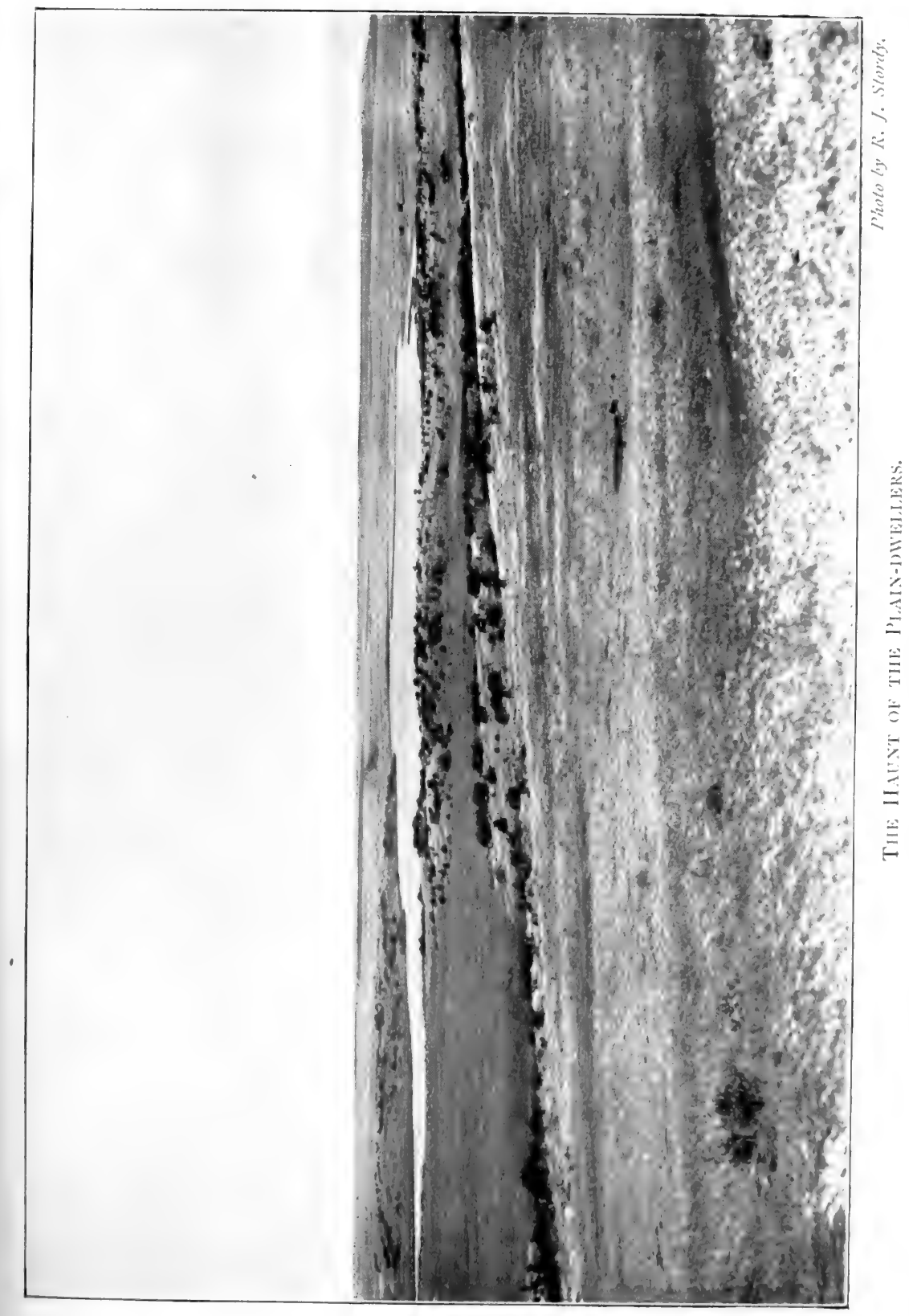



grounds, whereas really he is somewhat of a skulker. His favourite habitat is formed by the rocky and densely-wooded slopes of hills, and water is a very secondary consideration with him. He also penetrates a considerable way into dense forest and through thickets where at first sight one would never have imagined that the old bulls could have forced their horns. However, throwing his head back so that the sharp nose is pointed forward and upward and his horns lie flat against his flanks, he forces his way through a regular jungle, like a gigantic snow-plough. Kudu certainly exist in the following places-round Marsabit, the hills on the south shores of Rudolf, and plentifully in the northern Game Reserve, in the southern Game Reserve, in the wooded hills beyond the southern Guaso Nyero to the German border, and in the Baringo district. Also, I am credibly informed, on the hills round Meru, on the Mumoni hills and bush land adjoining, behind the Voi Hills, to the south-west of the railway line at Kenani, in the thick bush between Mazeras and the Shimba hills. Anything over 47 inches is a fair head, and over 54 inches would be good.

The Sable Antelope is rare and extremely local. He exists in British East Africa only in the Shimba hills and in the land running from there to the coast. It is doubtful if the species numbers 200 in all. Fortunately, the country is in their favour, or they would have been exterminated long ere the present day. Horns run small, by far the finest pair obtained measuring just over 4I inches, were shot by Capt. J. Murray, late A.D.C. to the Governor. Their further protection might at an early date be reconsidered, as they are by nature plain dwellers, and consequently 
less able to look after themselves than forest and bush animals.

The Roan Antelope is also local and comparatively uncommon. They are found near Muhoroni, where there may be 150 , in the Ithanga hills, where there are about 50 ; there are one or two small herds northeast of the railway line from Ulu and Simba, also on the southern extremity of the Uasin Guishu plateau, and they exist in considerable numbers along the German border from Lake Natron, mostly, however, on the German side. Horns run small, 25 inches being fair and anything over 27 inches unusual.

Oryx beisa is the common antelope of the northern deserts, though he does not penetrate as far into the waterless stretches as gerenuk or Grant's gazelle. In the flesh he is a handsome beast with his distinct markings and long, rapier-like horns. The mounted head, however, forms a somewhat disappointing trophy. Oryx are first met with to the north of Likipia, and become very common along the Northern Guaso Nyero and again round Lake Marsabit. Shooters along the North Guaso Nyero probably get an exaggerated idea of the numbers of this antelope, since in all probability they are on its banks considerably more than half the whole total of beisa in the Protectorate, a total which I doubt exceeds Io,ooo. Oryx meat is good, being like eland, though somewhat tougher. The hide is very thick and tough, being at least an inch in depth over the shoulders, and is prized accordingly by native warriors. After giraffe and buffalo, it forms the best material for shields. Where molested oryx are very shy, but occasionally they appear extraordinarily tame. The further north one goes the greater length the general average of horns attain. 
Indeed, at Marsabit a female has been shot with horns measuring 40 inches. A fair average head would be anything over 32 inches. The bulls have horns on an average rather shorter but more massive than the cows. It is difficult to distinguish the two sexes, but a solitary animal or an outlying sentinel is pretty certain to be a bull.

The Fringe-eared Oryx (Callotis) is somewhat smaller and has less distinct colouring. The ears are larger and more pendant and the tips are decorated by a tuft of dark hair. Any oryx found south of the Athi is of this species. Fringe-ears are found round Simba and Makindu and in all the bush country to the south, in all the bush country round Kitui, at intervals throughout the Taru desert and very plentifully on the Serengati plains and in the southern Game Reserve. As one approaches Lake Natron the characteristics of the species get less marked, and notably the ears are smaller and less fringed. The average horns of the Callotis would measure two inches less than those of the Beisa.

Waller's Gazelle or the Gerenuk is certain to be found in the most sandy and arid portions of the Protectorate, wherever there is bush with any approach to green foliage. His long neck and long legs enable him to reach high up any bush, and to acquire any succulent tit-bit he stands on his hind legs, placing his forelegs on a convenient bough. The gerenuk is very shy or rather perhaps his long neck and legs, small head and dull, monotonous colouring nearly always enable him to see the hunter before the latter sees him. After a short glimpse he seems to fade away between the bushes with head carried straight in front of him. $\mathrm{He}$ is common in the Serengati plains and the 
northern deserts, carrying in the latter districts the better horns. An average specimen would be 14 inches, anything over 16 inches being very good.

Giraffe.-There are two varieties in the Protectorate. The common variety, found in the southern and inhabited portions, and the northern variety (reticulata), occurring anywhere north of Likipia and being especially numerous in the northern Game Reserve. The southern variety has increased considerably in the last ten years and is very numerous in certain localities. I have seen as many as thirty in a herd both in the Ithanga hills and on the southern Guaso Nyero, and once more than seventy on the Serengati plains. Giraffe are most interesting and delightful beasts, and even those who have the most rooted antipathy to wild animals have yet to find a particular reason for the extermination of this species. Nature has cursed the giraffe with a skin which forms the most beautiful whip-lashes for bullocks in existence, and is valuable accordingly. No Dutchman can be trusted within miles of a herd, and will clear out any district with great celerity. If the species carried in addition horns to attract the sportsman and tusks to attract the trader he would long ago have been as extinct as the dodo, for he is easily ridden down and killed and has no means of defence. The Borana and also Somalis kill giraffe to make pots and buckets and, more especially in the case of the Borana, for the sake of his tail, the hairs of which they fashion into much prized necklacesanother instance of the sacrifice of a lovely creature to satisfy the vanity of the human species. The Abyssinians have exterminated their own giraffe some years back, and are now starting on those in the Protectorate. All giraffe have the rudiments of five 
horns, though with the reticulata they are more marked. This fact is not very generally known, and indeed one sportsman who camped within sight of a farmhouse, and shot a practically tame giraffe thereon, wrote to the Field newspaper and claimed that the results of his prowess in unexploited portions of Darkest Africa had resulted in the discovery of a new species of giraffe, as instanced by the fact that it possessed five rudimentary horns! There seems to be no reason why giraffe should not yet wander for centuries over certain portions of the Protectorate.

The Situtunga, or Speke's Tragelophus, is a very curious, swamp-inhabiting animal. He spends the bulk of his time in large papyrus swamps either swimming or clambering from tussock to tussock. He is provided with curiously elongated hoofs, which serve him both as paddles and give him a precarious footing on boggy surfaces. $\mathrm{He}$ is found in all the swamps which fringe Lake Victoria, and has also been shot by Mr. Philip Percival in a swamp on the Uasin Guishu plateau. Possibly they are far more widely distributed than we know at present. Even where common they are difficult to obtain, since they are very reluctant to leave their fastnesses. The best method to get a shot at a specimen is as follows. Finding a swamp which they are known to frequent, select any projecting arm which has any narrow passage leading to the main portion. Here cut the papyrus down, leaving a gap between the two banks of, say, 30 or 40 yards. Station native hunters will each morning examine the passage till they report the spoor of a bull entering the arm which is cut off by the gap and not returning. The animal is then located and when driven must return across the open space which has been 
cut. Anything over 20 inches makes a nice pair of horns.

Hunter's Antelope forms a connecting link between the hartebeeste and the impalla. $\mathrm{He}$ is very local and found only along the lower waters of the Tana. Anything over 20 inches is a fair pair of horns.

Soemmering's Gazelle is said to occur in the northeast corner of the British Boran.

Thomas' Kob or the Uganda Kob are found along the Nzoia river and from thence up to the Uganda border wherever the conditions are suitable. There used to be two or three small herds in the neighbourhood of Kipigori and Kibos stations, but these herds were most conveniently situated for shooters anxious to add another variety to their collection, and it is doubtful whether now there are more than two or three specimens left. Certain modifications in size and colour nearly earned for these herds the honour of a subspecies. Any over 20 inches are shootable horns.

Grevy's Zebra replaces the common variety in the northern deserts. Herds of both varieties may be seen together, but never mingling, in the neighbourhood of Archer's post on the northern Guaso Nyero. Once the river is crossed, Grevy's zebra entirely replaces the other species. This zebra is at least a hand the taller of the two, and stands about fourteen hands. The stripes are narrower and much closer together. Instead of barking, it emits a sound much more like a donkey's bray. It has been suggested that this species might be domesticated, but, apart from the difficulty of collecting live specimens in any quantity, there is no real reason to suppose that it would prove any more satisfactory than Chapman's variety.

Peter's Gazelle.-A much smaller and distinct 
variety of Grant's gazelle, only found on the coastal regions. So far as I know, only Mr. Jackson of late years has collected specimens of this gazelle. Several of us, however, partly through ignorance and partly through a desire to go one better than our neighbour, have at times so described ordinary Grant's Gazelle from the Serengati plain or some such locality.

Reedbuck in the Protectorate differ considerably both in size and shape of horns. I do not know whether the question is yet decided as to the existence of one or two varieties in addition to Chanler's. From Muhoroni to the Lake reedbuck are certainly very small, and an adult male would weigh little more than half as much as would be the case on the Uasin Guishu plateau. Mr. Stigand calls the former Ward's reedbuck and the latter the Bohor reedbuck. The more usual method is to admit but one variety, Ward's Bohor reedbuck. Reedbuck are very destructive to young crops, though otherwise an attractive adjunct to a farm.

The Giant Hog, though for some years regarded as a mythical beast, is in reality quite a common inhabitant of thick forest, where his spoor is everywhere abundant. He is black in colour, with comparatively short tusks, and weighs up to at least $600 \mathrm{lb}$. The native hunters have brought in plenty of skins, but not more than two or three Europeans, among whom is Lord Delamere, have secured specimens. Mr. Dugmore had the great luck, as well as skill, to photograph a living specimen in thick bush on the northern Guaso Nyero. Giant Hog are common in the Mau forest and the Kenia forest, especially in the neighbourhood of the Embu Station.

The Lynx is a recent discovery in British East Africa, but is possibly not very uncommon. I have 
only seen lynx on one occasion, near Lake Natron.

Wild Dogs are, unfortunately, fairly numerous, and apparently not decreasing, though man's hand is everywhere against them. There appear to be two varieties, one brindled and one black and white. Wild dogs hunt in packs; one after the other taking up the trail as the leader gets exhausted. Once on the trail, their quarry never escapes, and they will clear a district of game with great celerity. They kill their prey by disembowelling it, and a single dog is said to be able to accomplish this on even a large animal like a waterbuck, with a single tear. Lions are said to fear them, but I imagine that it would be a famished and bold pack indeed that ventured within the sweep of a lion's tremendous paws. They show little fear of man, and will often wait snarling in a semi-circle till several of their number have fallen before the rifle. There is, I believe, however, no authenticated instance of their attacking human beings; though no man, however armed, would have a chance against a pack.

Hyanas are of two varieties: the common, or spotted, and the striped. The former are ubiquitous, and the latter much more numerous than supposed. It may be remembered that the presence of the striped variety in the Protectorate was debated, but the question was set at rest by Mr. Schillings, who trapped, to prove his point, about I2O, mostly in the northern deserts. I have also seen striped hyæna in the Ithanga hills, and round Lake Natron. The spotted hyæna is extremely numerous, and is a most useful scavenger. Certain native tribes employ him exclusively as an undertaker. When hungry he becomes very bold and is quite capable of snatching a trophy resting against 
one's tent, or even under the fly. Occasionally, cases occur of the taking of native children by hyænas. They are very powerful, both in jaw and body; a single hyæna can carry off a donkey, or with one single wrench pull a dead zebra completely round. On the whole, it is decidedly fortunate that they are such arrant cowards.

Crocodile occur in the Tana, Athi, Thika, and Juba rivers and in Lakes Baringo, Rudolf, and Victoria Nyanza. In the Juba, they have an especially bad reputation, and natives are afraid to approach any part of the river to draw water, except when there is a steep bank. In Lake Baringo, on the other hand, natives paddle about among them with disdain and impunity. Hardly any animal is too large for a crocodile to tackle. Mr. Fleischman, the celebrated American.sportsman, told me how he and two other white witnesses saw a rhinoceros in the Jana river apparently held by the leg, and which eventually, in spite of the most frantic struggles, disappeared. It is difficult to conceive of any other explanation save that a crocodile had seized his foot, and, having curled its tail round a rock, had, with assistance, eventually pulled him in. The only objection to this conclusion seems to lie in the question why, if they can capture a rhinoceros, crocodiles do not equally batten on the hippopotamus which share their haunts. The length of crocodiles is frequently discussed, and people talk glibly of crocodiles of 25 feet. I know of no authenticated instance in Africa of a crocodile exceeding 16 feet. If a larger one exists he probably exists beneath the Merchiston Falls, where crocodiles lie in almost incredible numbers. 


\section{CHAPTER XXX}

GAME BIRDS FOR SPORT AND FOR THE POT

Although big game shooting may provide the finer sport, and is, of course, the great inducement which attracts travellers and tourist sportsmen to the Protectorate, perhaps bird-shooting gives to the farmer and settler a more continuous pleasure. The shooting of the commoner plain-dwelling antelope soon tends to become more pain than pleasure, while the shooting of the more dangerous kinds of game is too exciting and too strenuous to give the relaxation required for a short holiday from hard work. British East Africa is very well off as regards variety of game-birds and fairly so as regards quantity. Unfortunately, the quality of the sport that they provide is not quite so great as might be wished. The following are the varieties which for our purpose may be described as gamebirds: Bustards, guinea-fowl, francolin-usually called, though quite incorrectly, partridge-quail, snipe, ducks, sand-grouse, and pigeons.

Of these the ducks, snipe, and bustards perhaps provide the best food, and the sandgrouse and pigeons the best sport.

Of sandgrouse we have four varieties : the pintailed, the bridled, the chestnut-vented, and the close-barred, 


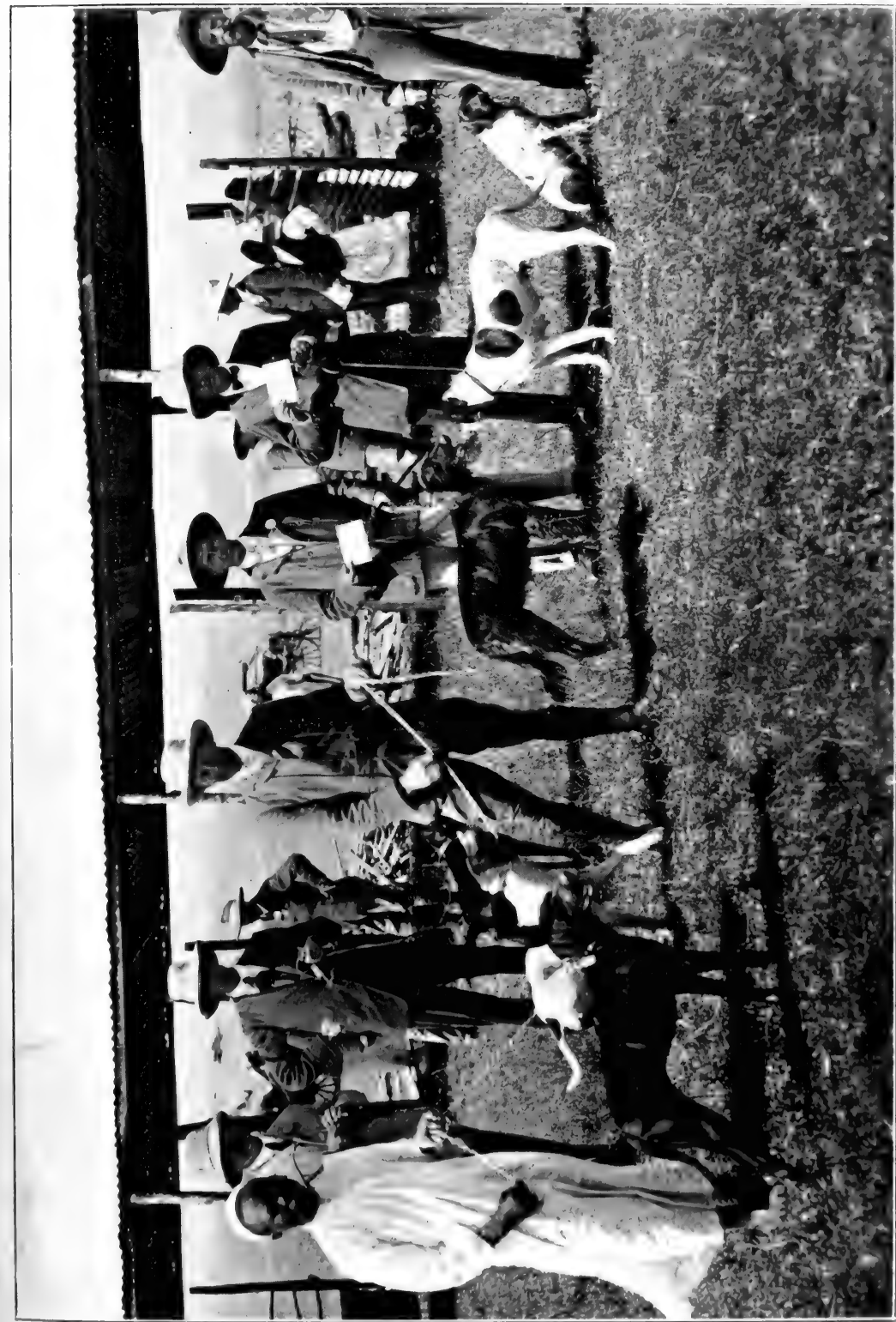

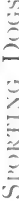



The first of these is the most common, and is found to the north and north-east of Kilma-njaro, on all the sandy hills and plains between Lake Magadi and the southern Guaso Nyiro river, also in Juba-land and on the northern Guaso Nyiro.

Sandgrouse may be shot walking up, and for the pot this is a very telling way, as a couple of barrels, one on the ground and one as they rise, may very likely produce a dozen birds. But for sport they must be shot as they flight down to water, which they do every day, either morning or evening. The morning flight, which commences about an hour after sunrise, is always much the best, but sometimes there is a good flight just before it gets dark. Never shall I forget a morning's sport which a friend and I enjoyed on the South Guaso Nyiro river. This river, which forms the west boundary of the dry and lava-strewn plains of the South Game Reserve, flows for nearly its whole course through a thick jungle of trees or between precipitous banks. At one spot, however, a belt of tall trees stands some fifty yards back from the river and a stretch of sand slopes gradually down from them to the sluggish stream which here ripples over a pebbly beach. Through this belt of trees the wild beasts of the Reserve come nightly to drink-antelopes, zebra, buffalo, and lion-and indeed I was attracted to the spot by having the pleasure of watching from the opposite bank by far the largest lion that I have ever seen strolling majestically down at mid-day. Beginning at about 6.30 a.m., it seemed as if every sandgrouse in the area east of Lake Magadi came to drink at this lovely spot. We had taken up our positions on the sandy stretch at about six o'clock on a sweetly cool morning, and a glorious sunrise heralded 
a scorching day. After about half an hour, which seemed to fly, so much of bird and animal life was there around to rivet the attention, the first musical cry of the flighting grouse was heard and a couple of birds circled once and then shot like plummets towards the water. As they reached the top of the belt they saw us and swerved, but too late, and three little corpses fell on to the smooth sand. Five minutes later came the first flock, some fifty strong, flying perhaps forty yards up and shooting straight at the high tree tops. As they topped these they broke in every direction like a covey of partridges in November and for my gun, at all events, proved altogether too difficult. In another quarter of an hour there was one continual stream whirling over the trees and circling and calling all round. I feel quite convinced that had we been so desirous we could have killed 500 brace of as difficult and sporting birds as anyone could possibly desire. We soon had all that we wanted for ourselves and porters, but could not refrain from staying and watching the wonderful sight presented. After a time, if we kept quite still, the birds would cease to mind our presence and would settle down in hundreds at the water's edge, where they seemed to take two sips and then make off. I do not think that the time occupied by each flock was more than half a minute. It seemed a poor repast to come, say, twenty miles for!

After watching for a couple of hours we went through the belt of trees to cross to our camp, and as we emerged a strange sight greeted us. We thought that the bulk of the birds had finished drinking, but it appeared that it was only the bolder spirits which had not resented our presence. For some hundreds of yards the sandy ground outside the trees was brown 
with birds which were sitting side by side in hundreds of thousands. As we emerged the whole ground seemed to rise with one roar and plunge towards the stream. The morning will ever remain to me a very vivid recollection.

The bridled sandgrouse is smaller than the lastnamed, to which its habitat appears somewhat similar; though I do not know that this variety exists in Jubaland, and it also extends further towards the north.

I have had twenty minutes or so very pretty sport with these birds at Larsamis and also at Merille in the desert country towards Marsabit. They appeared suddenly in thousands just as it was getting dark, and in the dusk were very difficult to account for.

The chestnut-vented sandgrouse is much larger than the other varieties, being about as large as an English partridge. According to Mr. F. J. Jackson, by far the most eminent ornithologist who has ever been in the Protectorate, the species range from Kilima-njaro northwards to Nairobi. I recall pretty sport with this bird on the Tana river in 1906.

The close-barred sandgrouse is very rare south of the Turkwell river, where it is common.

In addition to the splendid sport they afford the sandgrouse is excellent for the table, though, from its dryness, apt to pall after a while. Native porters, more especially Wanyamwezi, eat them with avidity. It is unfortunate that, for the most part, their favourite haunts are rather remote from civilisation.

The Pigeon, though not technically a game bird, is, like his cousin in England, capable of providing excellent sport. There are a considerable number of varieties, but the two which are usually bagged are the green pigeon and the large spotted variety with a 
yellow beak. Both kinds migrate in search of food, and if they can be caught on the line of flight will cause the expenditure of all the cartridges that one is likely to have in stock. The spotted pigeon is essentially a woodland bird and at times comes to the Mau Forest in huge numbers in search of a particular berry. Large bags are then occasionally made by the farmers in the neighbourhood and the sport is very fascinating. The green pigeon is more often to be met with on the belts of trees which edge most streams, and in scattered clumps. When the fruit of the wild fig trees is ripe the presence of the green pigeon is pretty certain, and a bag can be made. When flushed it dives off the tree like lightning and affords pretty shooting. A larger bag, however, can usually be made by lying in wait near a favourite tree and sending natives round to disturb the birds feeding in neighbouring woods. Green pigeons are good to eat but bad to digest.

Snipe are a migrant, and one which, unfortunately, has not been too plentiful of late years. There are at least three varieties : the double, the painted, and the common. Snipe may be found at certain seasons in the year in nearly all swampy grounds and round the edges of lakes and marshes. There is a small piece of boggy ground at the back of the military lines in Nairobi which is a pretty sure find after the rains. Londiani used to have a very good reputation for snipe, but lately this has not been sustained. As is well known, the warmer the climate or weather the straighter and easier snipe fly, and this rule holds good in the various parts of the Protectorate. As a comestible, however, the snipe never fails. The largest bag I can trace is about thirty couple. 
Bustards vary from the great bustard or pauw down to various varieties of Koorhaun. None are capable of providing much sport, but all are prized for the pot. The great bustard is a magnificent bird, and apparently knows it. An old cock will weigh 35 to $40 \mathrm{lb}$. -some people, indeed, put them much higher; and when two or three are strutting about on a bare plain, they have an appearance of conceit beside which the peacock is almost modest. When molested at all they are very shy, and can only be obtained with a rifle. Distributed over all the great plains, the species used to be especially common on the great Athi ; I am sorry to see lately a great diminution. Perhaps at the present day there are more along the plains which border the western slopes of Kenia than anywhere else in the Protectorate.

Francolin are present in great variety, and it is to them and to the guinea-fowl that the settler usually looks for his Sunday's sport and his week-day's dinner.

The following francolins are found, and the list is probably not yet complete: Jackson's, Gedge's, Coqui, Hubbard's, Grant's, Kirk's, Uluensis, Streptophorus, Elgonensis, Kikuyuensis, Hildebrandt's, Schuett's, Humboldt's, Pternistes cranchi, Pternistes boehmi, and the Spurfowl.

This is a long list, but for actual purposes it may be reduced to the ubiquitous spurfowl, of which perhaps twenty are killed to one of all the other varieties put together. This fine bird, which may be distinguished by his bare yellow throat and his upright carriage, is widely distributed throughout the Protectorate. Wherever there is cultivation, along the edges of streams or swamps, or in low scrub along a forest, you 
may be pretty sure of him. Like all the francolins, he lies very close during the heat of the day, but during the early mornings, especially after rain, and in the evenings, he gets very busy. I have seen the greatest quantity in the Kikuyu fields towards Fort Hall, along the Issiala river running into the northern Guaso Nyiro, and at Lugga, a pool in the northern desert; at either of the latter I feel sure that I could easily have obtained a hundred brace. The usual method of obtaining spurfowl is to walk them up in line, when they usually rise rather wild, go down with a charge of shot in their tails, and require help from an active dog. If the birds can be headed, pretty driven shots may be obtained, and the best method of doing this is by half-mooning. The best bag I have actually heard of is about forty brace.

It is rather sad to see the way in which spurfowl have decreased in the neighbourhood of a white settlement, and undoubtedly both this bird, guinea-fowl and duck are in need of a close season. It is said to be difficult to provide a satisfactory close time, owing to the fact that nearly all game birds breed twice a year in the Protectorate, and that at different times in different places. Probably, however, if it were illegal to kill or expose for sale spurfowl during July, August, and September, this species would obtain all the protection it requires.

Though most of the other francolins are common, the only variety which I have seen in numbers sufficient to afford a bag is Grant's francolin. He is a cheery little fellow, and in the bush-country which he frequents may be heard calling in every direction in the early morning. He gives much better sport than the spurfowl, as he flies much quicker and usually 
round the corner of a bush. Also, he is delicious to eat. The species is extremely common at the northern extremity of Lake Natron.

There are quite half a dozen varieties of guinea-fowl in British East Africa, several of which, though common, are forest dwellers. The settler, however, usually knows but two: the common guinea-fowl, which he shoots in the neighbourhood of his farm (either Reichenow's guinea-fowl or the Abyssinian helmeted guinea-fowl), and the vulturine guinea-fowl, which he may meet on his travels. The former can hardly ever be induced to provide a sporting shot at all, and trusts mainly to his pedestrian powers-wherein he is quite right, as the power of his legs is infinitely superior to that of his wings. To acquire his carcase, I would recommend allowing a dog to chase him into a tree, from which position he can be blown off at leisure. It is as well to make certain that the article at which you are aiming is a bird, and not a beehive. The writer made the mistake once, but will not repeat it.

The beautiful vulturine guinea-fowl loves desert sandy country, and is almost certain to be found there in the neighbourhood of water. He is a far finer flier than his relative; indeed, I have seen a flock of vulturines rise and come rocketing over on the wind almost out of shot. On the ground they can be easily distinguished by their long tails.

The Quail is sometimes very plentiful, and of course affords good sport. The objection to him is that he is easy to shoot, hard to pick up, a small mouthful when cooked, and won't keep long. The varieties in the Protectorate are: Delegorgue's, the common, and the button quail. Of these the first named is much the 
most numerous and widely distributed. I have met him nearly everywhere throughout the Highlands, but only once in exceptionally large numbers, that being on the Yatta plains in I9I I.

Wildfowl are rich in variety in the Protectorate, but unfortunately they cannot be seriously regarded from a sporting point of view.

Seven or eight years ago the duck shooting in Lake Naivasha was quite good; Sir Donald Stewart, Mr. R. J. Stordy, and two more guns on one occasion certainly killed more than 150 . Year by year since then the number of ducks on the lake has decreased and their shyness has increased, till now it is a lucky gunner who gets more than half a dozen. The other large lakes, the rivers, and especially the small reedlocked pieces of water, all contain duck, and generally a goose or two; but I know nowhere where by flighting or any other method a large bag can be obtained. During the last six or seven years the rainfall throughout the Protectorate has probably been a good deal below normal, and certainly not only have the greater lakes sunk considerably but many smaller pieces of water have dried up altogether. This circumstance very likely to a great extent accounts for the diminution of wildfowl, a diminution which, it may be hoped, is only temporary.

For all species of bird-shooting a dog is generally essential and always desirable. He may be either a pointer, retriever, or spaniel. Unless bred in the country, the last two feel the heat a good deal, but those born in the Protectorate seem pretty well inured. Mr. Archer, District Commissioner of the desert country round Marsabit, breeds a race of liver and white spaniels which are indefatigable on the hottest 
day-some say too indefatigable. The owner of sporting dogs cannot be too careful in having the ticks removed from their bodies every day, and should never fail to check the accuracy with which this task is accomplished. Insufficient attention to this operation accounts for most of the deaths from tick fever. 


\section{CHAPTER XXXI}

GAME RESERVES

Opinions with regard to the extent and character of the means by which the game animals of the Protectorate should be preserved are many and various, and the subject is periodically discussed with considerable heat. The poles of such opinions are represented on the one hand by those who would exterminate at once, without distinction, all the larger fauna with the view, at some distant and visionary date, of filling their place with the settlers' flocks and herds; and on the other by those who would make the country nothing but one vast playground and game preserve, regardless of the progress and growing congestion of the human race. Between these poles range ideas and suggestions of every kind. Perhaps, however, the collective opinion is, as it should be, sober and reasonable; certainly a sporting community such as form the bulk of the population will be averse to authorising greater destruction than is absolutely justifiable.

Summarised, popular opinion runs somewhat on these lines: the prime consideration must be the benefit accruing to the human race, whether black or white. Where the presence of game at all or in excessive quantities is deleterious to the actual well- 
being, happiness, or prosperity of the bulk of the population, then that game must be banished.

Short of this, it is admitted that we owe a certain duty to the actual wild denizens of the country. When we took upon ourselves the privileges which attach to our great Empire, we also assumed certain responsibilities. One of these responsibilities, a minor one perhaps, but still very real, is to see to it that none of the splendid and beautiful forms of animal life contained in that Empire should be ruthlessly or needlessly exterminated. This is the second consideration; and on these two considerations I believe that the large bulk of our population, both settler and official, would be agreed.

It is as to the best means to effect this end, i.e., to preserve the maximum amount of game at the minimum amount of inconvenience, that opinions mostly differ. It has been asserted by some that it a close season were imposed the farmers and settlers themselves might be safely entrusted with the task of preserving what amount of game they desired, while the Government could see to it, through their gamerangers, that no species came in danger of extermination. Those who hold this opinion are aware, of course, of the fact that wherever you pick the area to be reserved for game it is sure to be a Naboth's vineyard to someone, and hold that game is likely to get a worse name through this supposed usurpation than if such land were actually thrown open for settlement. Against this view those who advocate Game Reserves argue, "By all means let us have a close season; but that is not enough. We believe, certainly, that a large proportion of the farming occupiers will, if only for the sake of sport, do 
their best to preserve an adequate supply of game animals. Unfortunately, from our point of view, there are very many who, either because they are averse to the presence of game or because they lack the capital to develop their holdings, and so must live as best they can, will destroy every head of game that they can lay hands on. This large proportion may at any time cause the extinction of some lovely and harmless antelope. Again, there are at the present time certain animals, such as the eland and buffalo, which are under a taint of suspicion as bringing in their train tsetse-fly or other obnoxious parasites, and therefore are inimical to stock raising. Should this suspicion develop into certainty, these species must disappear from all distinct lands, and therefore, if they have no settled sanctuary two of the most glorious types of game animals will disappear from our midst. Further, we have here a virgin country, a country which has changed in no essential from time immemorial, a country over which native and game alike have wandered happily and freely since the Flood. Granted that you could preserve intact representatives of every genus and species over the various farms and other artificial divisions into which the country is now being divided, you cannot preserve the natural conditions and type of country under and over which the game flourished."

One may take it that it was such or similar arguments which led here, as in America, Canada, and South Africa, to the formation of Game Reserves.

At the present moment in British East Africa there are in existence two large Reserves, one of which shelters the more southerly varieties of game found in the Protectorate and one the more northerly. 
The Northern Game Reserve occupies some 14,000 miles, consisting mostly of desert country, and is at present beyond the furthest limits of colonisation. The southern boundary of this large tract is the north Guaso Nyiro river, and the sanctuary forms a square block to the north of this line artificially bounded on the other three sides. Although, as I have said, the area comprised is mostly arid and sandy, certain

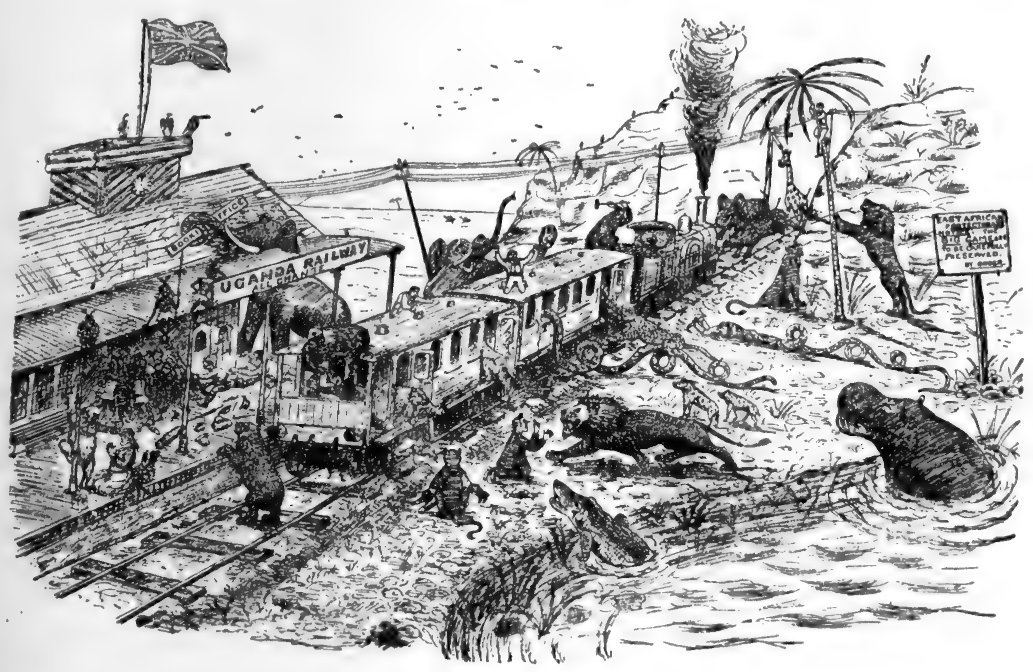

Through the Reserve.

(By permission of the Manager of the Uganda Railway.)

portions are probably fitted for white settlement, and in the course of time its area is likely to be curtailed.

There is no great variety, or indeed number, of animals in the Northern Reserve; shortage and poverty of grazing are responsible for that ; but of the species included some, at all events, are not found in the Southern Reserve. Among its inmates are elephant, of which there are undoubtedly several thousand, rhinoceros, buffalo, giraffe (reticulata), 
eland, Greater and Lesser Kudu, impala, Waller's gazelle, oryx (Beisa), Grevy's zebra, waterbuck (defassa), and the two northern forms of Grant's gazelle, besides the smaller buck. It is probable that, finally, this Reserve will be one of the last strongholds of the elephant, and a means of ensuring the preservation of Greater Kudu, Oryx (Beisa) and Grevy's zebra.

It is to the Southern Game Reserve that most attention is directed. The tract of country set aside here runs parallel to the railway line from Nairobi down to Tsavo, and contains about Io,ooo square miles. The land comprised in the area varies considerably, but a very large proportion of it is quite unfit for white settlement. With the exception of a small swamp or two and a few waterholes, the only permanent water is that of the Tsavo and Southern Guaso Nyiro rivers, which form the southern and western boundaries, and also the head waters of the Athi. Certain portions might possibly be suitable for sheep, one to ten acres, and a smaller portion might perhaps grow cereals if carefully cultivated on the dry-farming principle; as a whole, however, it may be said to be agriculturally valueless.

Travellers on the Uganda Railway are apt to get a somewhat erroneous idea both as to the nature of the land comprised in this Reserve and of the amount of game contained therein. Heading northwards, the line cuts the Athi plains, which it traverses for some thirty miles, and to the west may be seen great stretches of fairish grazing, extending apparently as far as the eye can reach and covered with huge herds of zebra, wildebeeste, antelope, and gazelle. One is apt to say, "If I can see so many thousand head of game in so small a section of this large district, what an incredible amount of game the whole Reserve must 
contain." Such an idea would be entirely mistaken. At certain seasons of the year, at all events, probably more than half the total head of game in the Reserve can be seen from the train. The small section of the Athi plains cut off to the west of the Railway contains the only good piece of grazing in the whole Reserve, and the game which is concentrated on it is able to drink at the upper waters of the Athi. The fact that this good strip of grazing runs parallel to the line is productive of both good and bad. It is, on the one hand, eminently desirable that the animals sheltered in a sanctuary should minister as far as possible to the pleasure of the public; and it cannot be denied that the glorious vista of animal life seen from the train windows yearly affords gratification to thousands of those who travel on the Uganda Railway. Moreover, its presence adds materially to the revenue of both the railway and the Protectorate. On the other hand, the false impression created that a large tract of fine grazing and agricultural country is being held up in the interests of game is the cause of curious and envious eyes being cast on a region that is really most undesirable.

In the Southern Game Reserve are included some fair herds of elephant, an increasing number of buffalo, plenty of rhinoceros, perhaps fifty Greater Kudu of both sexes, a fair amount of eland, and waterbuck, and an abundance of Lesser Kudu, giraffe (common), Oryx callotis, common zebra, gerenuk, wildebeeste, impala, Grant's gazelle, Thomson's gazelle, reedbuck, and Coke's hartebeeste.

As I have said, the railway line forms the eastern boundary of the Reserve, and to the east of the line comes a settled area. The farmers in this area con- 
tinually bring complaints, and very natural complaints, of the damage they incur through the inroads both of the game in the Reserve and of the lions which follow that game. These farmers are, as a whole, a most sporting lot, and have never yet collectively made any suggestions for limiting either the size of the Reserve, or of the quantity of animals contained in it. What they do ask, however, is that they should be afforded some protection ; this protection, they suggest, would be adequately afforded by a game-proof fence running along the line for a distance of some thirty miles.

Now it may be asserted, and with an element of truth, that the farmers in question have not a very substantial grievance. A considerable proportion of them took up their farms, not only aware of the presence of great herds of game on their land, but in some cases actually because of its very presence. Furthermore, that the money and energy expended on the whole area in question is very small; too small altogether to demand the expenditure of some six or eight thousand pounds of Government funds. Admitting both these arguments, I venture to say that the real point is obscured. We have here in our Southern Reserve a national asset-an asset which most of us hope will delight naturalists and nature-lovers for centuries to come. As owners of that asset, I venture to assert that it is our duty to see that its presence inflicts, not only the minimum of inconvenience on those who may at the present moment be affected by living in proximity to it, but also on those who by purchase or otherwise may be affected by it to-morrow or in the immediate future.

As to the fence in question, the Government have 
admitted themselves to be in sympathy with the idea, but plead a shortage of funds. A suggestion was put forward that the financial help of the Society for the Preservation of the Fauna of the Empire should be invoked. This society, which is better known to its friends under the title of "The Fauna," and to its enemies as "The Penitent Butchers," has always been most active in the past to prevent needless and excessive destruction of both beasts and birds. It has admittedly done a great deal of good work, even if, as its detractors aver, it has occasionally erred in being somewhat officious; an accusation which, as a "Penitent Butcher" myself, I must strenuously rebut. It must be confessed, however, that it is hard to see how such a society can reasonably be expected to expend a large sum of money to protect the property of others. It must be borne in mind that not only has the game been a source of revenue to the Protectorate in the past, but that at the present day the Game Department has, in licences and fines alone, a sufficient surplus income in one year to meet most of the expenditure in question.

The object of a Game Reserve, it may be presumed, is, in addition to the moral obligation to the game itself which I have adduced, to provide the maximum amount of pleasure to the large and increasing class of those persons who are interested in wild animal life. A further object is to provide an area within which scientific observation and experiment may be carried out, and by this means to provide both benefit and gratification to many who will never be able in person to visit the sanctuary. To attain these ends, it obviously is not desirable to close up the Reserve and allow the entrance only of game rangers and privileged persons.

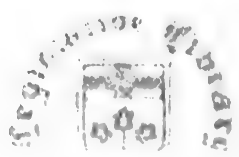


On the contrary, sight-seers, naturalists, and men of science should, and no doubt will, be encouraged. As the country gets more and more settled up and the game moves back into the unhealthy and barren areas, one conceives that bungalows or rest-houses will be erected at suitable places in the Reserve. Visitors and scientific expeditions will hire the same, and, armed with the camera, will still enjoy the sport of the pioneer. Possibly, also, specimens will be captured to supply periodically both zoological gardens and museums. A considerable source of revenue will by these means be added to the Protectorate.

Rather a vexed question is raised by the carnivora in the Reserve, and more especially by the lions. Some settlers would have all carnivora destroyed, others would have them kept in check, and others, again, would have them entirely preserved. Personally, I would put in a strong plea for the lion, at all events within certain limits. Not only is he, to my mind, the grandest beast in Africa, but his habits are intensely interesting, and unless provoked it is the very rarest thing, if not absolutely unknown, for him to molest human beings. In the whole history of the Protectorate there may be authentic cases of a dozen maneaters; and many of these, no doubt, had been at some previous date molested or wounded. If, however, it be held necessary from time to time to reduce the number of lions, it is a task that should be entrusted solely to the officers in charge of the Reserve. On no account should privileged persons be allowed, as has occurred too often in the past, to enter the sanctuary ostensibly to kill superfluous lions. I would go further, and say that the only method by which carnivora should be killed therein is by the unsporting but most deadly 
method of all, poison. Except for the actual purpose of self-defence, the rifle should be unknown in a game reserve. It is a matter of intense gratification to all settlers that we have in the person of the chief gameranger, Mr. Woosnam, and of his second in command, Mr. Percival, who is more especially responsible for the Northern Game Reserve, two such eminently conscientious and unbiassed officials. Both are first-class sportsmen and well-known naturalists ; men, moreover, who, though "loving the big game like a brother," do so in no fanatic spirit, but rather with a just and reasonable appreciation of the additional interests of the human population, both white and black. 


\section{CHAPTER XXXII}

FISHING

THere are probably few countries where a greater variety of sport can be obtained than in British East Africa, and of all these branches none has been so little exploited or is so little known as the ancient sport of angling.

Up to the present time little or nothing has been heard of the prospects of angling in this Protectorate, because the majority of sportsmen leave England thinking only of shooting, and bring no fishing tackle with them while those who are fishermen, and bring their tackle, generally fail to obtain any trustworthy information as to where and when to fish and what to fish with; or they are unlucky in visiting rivers at the wrong season, or rivers in which good fishing is never to be had. Thus the angling possibilities of the country have been left almost untouched, and the fact that there is most excellent fly-fishing to be had in many of the smaller streams, when they are low and comparatively clear, remains practically unknown.

In addition to this, there are probably few places in the world where such magnificent sea fishing can be obtained as at and near Mombasa, and other ports on the coast, particularly Malindi. Here, again, still less 


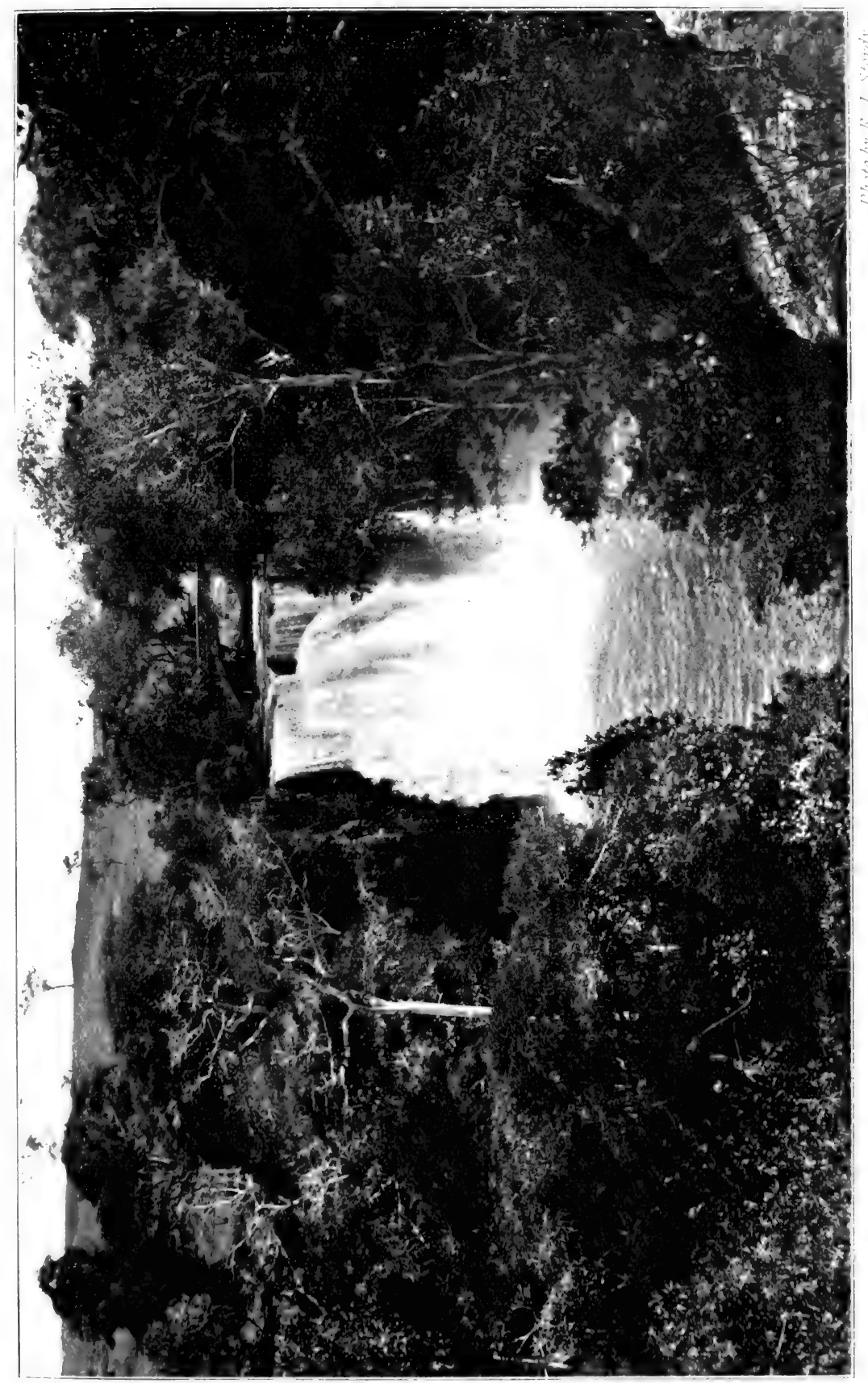



is known of the fishing, except that the fish are there, and will afford excellent sport to the man who knows something of the game.

Most important of all is the fact that the prospects of successfully acclimatising trout in the high altitude cool streams are most encouraging. They are already doing well in the few streams in the Aberdare mountains into which they have been introduced, and the fish rise freely to a fly and have already been caught weighing as much as $6 \frac{1}{4} \mathrm{lb}$. Fishing in these streams is at present prohibited until they are thoroughly stocked, and it is intended during the next eighteen months to stock all the cold, clear streams flowing from Mount Kenia, and, if possible, any other streams in the country which may prove to be suitable. If these experiments are successful, and there is now little doubt that they will ultimately be so, the trout fishing in British East Africa will be some of the best obtainable in the world. The lucky angler will find himself camped among the most delightful surroundings. Semi-tropical and Alpine vegetation mingle in wonderful variety and luxuriance, and will delight him if he is also a botanist; vast areas of cedar, juniper, and podocarpus forests, and undulating ridges of giant heather and open moorland, intersected by numerous rushing mountain streams, clear as crystal and cold as ice, flowing from the wonderful equatorial snows. The zoologist angler also will find much that will delight him and send the blood tingling through his veins, for in British East Africa it will not be a case of "here and there a trout, and here and there a grayling," but "here and there a trout and here and there a rhinoceros or an elephant or a buffalo," and the sportsman will be able to combine a fishing ex- 
pedition with some of the best big game shooting in the world.

An attempt will now be made to give some detailed information of the fishing to be obtained in British East Africa.

Firstly, the trout fishing is something to look forward to in the near future, and this will be in the cool high altitude streams at 6,00o feet and above. At present there are no fish of any kind in these mountain streams, although there is an abundance of food, including fresh water crabs, which it has been found the trout feed upon readily and which are probably largely responsible for the rapid growth and brilliant colouring of the trout already in the streams in the Aberdare mountains, but which, fortunately, do not prevent them rising to a fly. The possibility of trout doing well on the Equator was naturally thought remote in the beginning, even when account was taken of the perfect appearance, food, and temperature of many of the streams in the Protectorate. That the experiment of putting trout into these streams was made is to the credit of $\mathrm{Mr}$. F. S. Jackson, Mr. S. L. Hinde, and Mr. Grogan. The success of their experiment looks like being a source of lasting satisfaction to these gentlemen. If this success continues, as now appears almost certain -in Africa the word "almost" must never be left out -an asset of great value will be added to the country. All fishermen will note the prospects of the Protectorate with pleasure, and must feel delighted that these prospects are being furthered by $\mathrm{Mr}$. Woosnam, who unites his knowledge as a naturalist to his skill as an angler.

Secondly, in almost all the East African rivers below 5,000 feet there are several species of a large sealed 


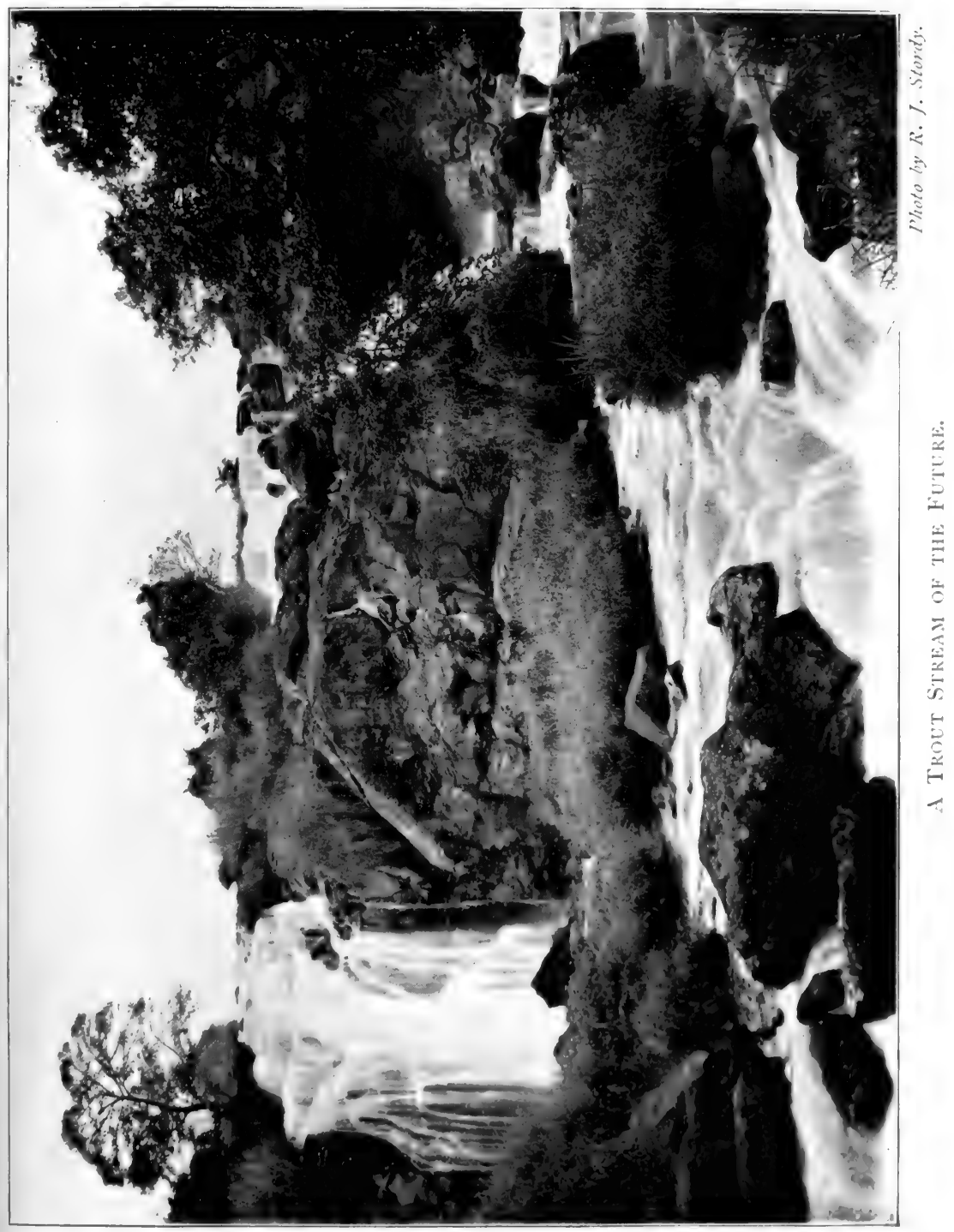



barbel which grow to a size of about 15 to $201 \mathrm{lb}$. This is a fish which will rise freely to a fly and will also take a spoon bait or minnow, but only when the water is comparatively clear. This is a very important point, and the lower and clearer the water is, the better will be the sport obtained. It is almost useless fishing with a fly or spoon bait in rivers which are thick and muddy, and it is unfortunate that almost all the larger rivers in British East Africa are muddy all the year round, although running swiftly. However, sport can be obtained even in these larger muddy streams with a bait such as meat, or dough, and considerable catches are often obtained and very large fish landed. With such baits large siluroid fishes are also to be caught in numbers. The fisherman must therefore seek the smaller clear streams which are tributaries of the larger rivers if he wishes for sport with fly or spoon. In these streams sport is not always to be obtained, and East African fish, like their European relatives, will not rise to a fly every day. But when a comparatively clear stream is found running into a larger and muddy river, excellent sport with a fly or small spoon may confidently be expected at some time in the day, generally in the afternoon, but on some occasions the present writer has found fish rise best during the heat of the day. These barbel, which are caught on a fly or spoon, generally run from a pound up to four pounds, and fight well when hooked. The largest fish known to have been killed on a fly was one of Io lb., killed on a salmon fly in the Athi river when it was comparatively low and clear.

A catch of twenty-one fish on a small red spinner with a light 9 -foot cane rod was made by Mr. R. B. Woosnam, the game warden, on the Nairobi river 
between 4 p.m. and sunset, the fish running from a pound to four pounds.

There is also excellent fishing to be had in Lake Victoria and some of the rivers flowing into the lake. Probably the best sport is to be obtained at Jinga, where the water from the lake finds an outlet to the Nile. Here some astonishing catches have been made with spoon and minnow, and there seems an unlimited supply of fish running from two or three pounds up to twenty. In December a resident sportsman landed fifty-one fish in three days, the best catch being sixteen before breakfast averaging ro $\mathrm{lb}$., the largest fish weighing $2 \mathrm{I} \mathrm{lb}$. On another occasion he landed during three days' fishing forty fish weighing together $405 \mathrm{lb}$.

Of the sea fishing so little is known that it is impossible to give any precise details. There are many species of raptorial fishes running up to over roo lb., as well as small sharks which give extraordinary sport on a suitable rod. Certain stages of the tide appear of importance, and a bait which spins does not appear to be so effective as one which swims steadily in the water.

Mr. Woosnam tells me that fishing from the landing steps at Mombasa with an artificial sand-eel and small trout rod, he hooked a fish estimated to be about $70 \mathrm{lb}$. weight and resembling a tarpon in appearance. However, his acquaintance with this fish only lasted during the time it took to run out 30 yards of line (about four seconds), and he has never had an opportunity of investigating the sea fishing of British East Africa since, nor any suitable tackle, but there is little doubt that great possibilities await the expert who is properly equipped. 
Each settler who is also a fisherman should accordingly not neglect to bring with him his fishing tackle. For the trout and also for the coarse fish which rise so well in many small clear streams, a light trout rod, landing net, flies, etc., will be wanted. For this purpose one of those rods which screw into 2 foot lengths and is accordingly easily packed and less liable to be broken is desirable. For heavy coarse fish a pike rod, reel, and line are requisite. Even should the settler have no fishing on or in the immediate neighbourhood of his farm, he is sure to be able to get to a stream in a day or two, and as is well known, there is no better distraction to the mind than a holiday spent in this way. Nor should sea-tackle be omitted. It is as sure as anything can be that when once the nature and habits of our sea fish become known, we shall have sport at our doors in no way inferior to that enjoyed along the shores of Florida or elsewhere. 


\section{CHAPTER XXXIII}

\section{HORSE RACING, HUNTING AND POLO}

As may be imagined, in a Colony where the principal industry is farming in one form or another, any sport connected with horses is not likely to be neglected. Ever since there were 100 resident Europeans in the Protectorate Nairobi has had its race-meetings. At first, of course, such meetings were very informal, though by no means the less pleasant on that account. Everyone who had a horse with four temporarily sound legs meant having a ride ; and many such a horse after pulling his master, wife, and friends up to the course came from between the shafts and for one brief crowded hour became a racehorse, to resume in the evening his less ambitious rôle. All that is now altered. Nairobi has a very pretty race-course and three properly managed and conducted meetings are held a year. Not only are such meetings most enjoyable in themselves, but they form the object for a general meeting of farmers, prospectors, and planters. The three weeks are therefore crowded with affairs of business, affairs of politics, and social pleasures of all sorts. At these times the planter from Malindi or from the Lake, the sheep farmer from Naivasha, the horse-breeder from Kenia, and 
the hunter and prospector from the back of beyond, shake out their exceedingly creased blue suits and still more unused dress clothes and meet once more their old friends. These weeks form the chance of a lifetime for the unmarried girl. The settler from the back blocks has very likely not met a white lady since his last race meeting and is ready to see beauty in the most meagre charms. She must be an unattractive damsel indeed who cannot, if so desirous, bring at least one eligible bachelor to her feet during the time at her disposal.

As I have said, the week is devoted as much to business as pleasure. Thus Brownsmith treks in, a three days' journey, perhaps, from his farm; he proposes for himself the following programme: Two days' racing, at least one dance, a meeting called to discuss the labour problem, quarantine, or whatever may be the burning question of the hour, a meeting possibly at which the Governor will take the opportunity of giving some statement of policy, a new oil engine to be bought, a wagon and three ploughs to be repaired, a game of polo, a cricket or golf match, some produce to be sold, advice, which probably he won't follow, to be obtained from the Agricultural Department, stores and whiskey for the farm to be bought, and last, but by no means least, the inevitable interview with the Land Office.

The town assumes an air of revelry during the week, and to the accompaniment of song and dance, with perchance a certain amount of horse-play, a very fair quantity of spirituous liquors is consumed. Boisterous spirits are certainly in evidence; but those worthy citizens who write regularly to the papers to complain of the disturbance to their ordered lives 
should remember that what they call excess represents merely the small pleasures omitted for six months but now concentrated in some five days.

Although it cannot be denied that in certain parts horse-sickness occurs periodically, yet it is pretty certain that British East Africa, for its size, is likely to take quite a high place among horse-breeding countries. The insect which carries horse-sickness in its two forms is not yet known, but it is certain that it is nocturnal, and in all probability some form or other of mosquito. Those horse-owners who see that their animals are shut up by nightfall in a decently constructed stable are likely to suffer very few losses. If the locality bears a bad name for the disease, a good preventive is to rub the horse over every evening with a cloth damped in kerosine. Another precaution where stables are of bamboo or communicate internally is to have a small fire of greenwood in the windward box whence the smoke can permeate throughout the whole stable. Some stables are made mosquito-proof, a safeguard of somewhat doubtful benefit, since, while they cannot effectually keep out mosquitos, they will to a certain extent help to retain any that make their entrance through the door. Boxes should be separated by partitions extending right up to the roof. It must occasionally happen that a horse is out at night, and if the box is isolated the opening of the one door affects one horse alone. Again, if one horse be infected the carrier of the contagion cannot communicate the disease to the adjoining boxes. Apart from horse-sickness, which, after all, is very far from widespread, and is certainly on the decrease, horses do splendidly in the Protectorate. There are great stretches of short, sweet grass, abundantly watered, 
with a most suitable climate. The portions of the Protectorate which for the present seem more especially suitable for horse breeding are perhaps western Kenia, parts of the Uasin Guishu plateau, and Likipia.

There are almost as many types of horse in the country as there are types of settler. We have English horses, walers, Africans, Basutos, Arabs of both types, Indian country-breds, Somalis, Abyssinians and Boran, and, best of all, a rapidly growing and improving class of country-breds. All do well, and there are customers for every class. The animal the ordinary resident farmer wants for the most part is, perhaps, a small, strong and hardy animal. Small, because he is easy to get on to and will not eat so much. Strong, because he will be wanted to be ridden over the farm all day and every day. Hardy, because, though usually he will be kept well, he will at times be wanted for long journeys where he will have to pick up what grazing he can find and sleep cold at night. To produce such an animal a likely cross would be a good class Arab stallion with the best Abyssinian mares obtainable. Abyssinia is full of horses of very varying excellence. While the majority of ponies seen in the south and in the weekly horsemarket at Adis Ababa are small and not too well shaped, there are some extremely useful animals to the north, more especially in the Walla country. It would mean a great deal to the Protectorate if a hundred of the best of these mares could be imported. During I9IO and I9I some fourteen or fifteen hundred horses from the Boran country were driven down into the Protectorate by Somalis, the majority of them being run across the Abyssinian frontier. 
This influx of very small, poor and none too healthy ponies is by no means an unmixed benefit. Certainly it enables the settler to have a mount-it can hardly be called a pony, still less a horse-at a reasonable figure. That is to the good; but it must never be forgotten that British East Africa is a small country, and as such must be distinguished by the excellence rather than by the bulk of its productions. I cannot think that even the sight of so many animals of the poorest class is likely to improve the name or prospects of the horse-breeders of East Africa. For export purposes, and more especially for the production of an animal suitable for Army remounts, such as is required in the Indian Army for instance, a larger and superior sire is required. In this direction Mr. Berkeley Cole has very courageously led the way by importing that fine stallion, Bobrinski, who will be remembered as an early favourite for the Derby won by Pretty Polly, but who subsequently failed thoroughly to fulfil his early promise. Size, shape, temperament, and breeding cause this horse to be especially suited to the requirements of the Protectorate.

This variety of horses and ponies is naturally responsible for a great variety of races. Thus we have three classes, separated by a great gap in the weights ; differing, moreover, so greatly in quality that the weight allowance is year by year increasingly insufficient. These three classes are: English, South African and Australian horses; Arabs, East Indian and country-bred; and lowest in the scale Somalis and Abyssinians. These have each their own races, both on the flat and over jumps, and attempts are also made to bring two classes together. It may, however, be accepted that it would take much more than the 
accepted allowance of $2 \mathrm{I} \mathrm{lb}$. to bring the best Somali and the best Arab together over any distance. With Abyssinians the case is somewhat different, since there exist in Abyssinia without doubt ponies with much good Arab blood in them and occasionally with something better. It goes without saying that no weight could bring the best Arab ever foaled within hail of an English thoroughbred of decent class. The East African breds form another problem, since every year they improve in quality, and before long no doubt will have to take their place in the highest class.

A sample of a possible programme for a two days' meeting might be :

First Day.

First Race. An Arab handicap over say 5 furlongs.

Second Race. A Steeplechase for all horses over I $\frac{1}{4}$ miles.

Third Race. The Produce Stakes of British East Africa for all 2 and 3 year old horses got and foaled in the Protectorate. Weight for age, sex, and inches allowance.

This race is the local Derby, being the most valuable as well as naturally the most interesting race of the year. At present it is confined to horses I4.2 and under. This restriction, however, will probably be removed in the near future, as the tendency is for East African breds to increase in size yearly. In the course of a year or two the race is likely to be run in two classes, the one under this height, and the other unrestricted.

The Fourth Race.-For horses the bona fide property of resident farmers-12.7. No rider to have ridden six winners in the Protectorate. Distance 6 furlongs. 
Fifth Race.-The King's African Rifles Cup for ponies owned by officers serving with the King's African Rifles, I 4.2 and under. Catch weights I 2 stone.

This used to be a popular event, bringing forth considerable competition. The reduction and dispersal of the force has unfortunately destroyed much of its interest.

Sixth Race.-A hack race or polo scurry. Distance, say, 4 furlongs.

Seventh Race.-A selling race for Somalis and Abyssinians.

The programme for the second day might run : First Race. - A hurdle race for Somalis and Abyssinians. Distance 5 furlongs.

Second Race.-A handicap for all horses. $\mathrm{I} \frac{1}{4}$ miles. Third Race.-An Arab steeplechase over $1 \frac{1}{2}$ miles. Fourth Race.-The Safari race for Somali and Abyssinian ponies which have never won a race. I I.7. Distance $2 \frac{1}{2}$ miles. No rider to have ridden six winners in the Protectorate.

Such a race is designed to please both the public and all resident sportsmen. Entries are numerous and many of the jockeys as well as the quadrupeds exhibit eccentricities of the most pleasing character. The hardy little ponies usually get round in their own time fairly comfortably, but many of the riders are much distressed at the finish.

Fifth Race.-A handicap for all horses got and foaled in the Protectorate. Distance 6 furlongs.

The Sixth Race might be a match.

The Seventh Race.-A selling race for the Arab class.

The programme has to be drawn up with a due regard to the various types of animal engaged; and 
further with a due regard to the types of owner who wish to race. The task is therefore one of considerable magnitude and naturally the stewards invariably fail to please more than a certain proportion of those for whom they cater.

The East African Turf Club have a nice course at Nairobi, where, usually speaking, the going is good. There are many fine challenge cups and, generally speaking, it may be said that the club is in a prosperous condition. Like most other institutions and industries in the country, the club owes its greatest debt of gratitude to Lord Delamere, but much is also due to the past and present secretaries, Messrs. Eastwood and H. F. Ward, as also to Lord Cardross, for many years handicapper to the Club. The best jockeys on the flat in the Protectorate are Messrs. H. Tarlton, C. B. Clutterbuck, and F. Greswolde Williams; while over jumps Mr. R. B. Cole is perhaps the premier performer.

There is also a yearly meeting at Nakuru, which usually takes place after the Agricultural Show. This is a most sporting up-country meeting, where many more farmers find the courage to ride their own horses ; and if the class both of horses and riders be somewhat lower than in Nairobi the sport is none the worse on that account.

Polo is almost certain to have a big future in a country where horses do well, where the making of a first-class ground is everywhere a matter of ease, and where the climate is suitable to the pastime nearly the whole year round. At present the only centre for regular play is Nairobi, but there is also a club on the Uasin Guishu plateau and play occasionally takes place in the neighbourhood of Nakuru. The ponies in use 
are of all breeds and varieties with Arabs predominating. Although the price of Arabs has increased considerably of late years, yet even now decent untrained ponies may be shipped either from Port Sudan or Bombay and landed at Nairobi at an inclusive cost of little more than forty pounds. These have up to the present formed the best sources for obtaining polo ponies, though good ponies have also been imported from South Africa. In a year or two, if not already, there will be no necessity to import, since the produce of the Protectorate itself is at least up to Arab form.

Up to 1909 polo in Nairobi carried on a somewhat fitful existence, chiefly under the auspices of the King's African Rifles. In that year, at the instigation of Mr. Berkeley Cole, the Club was reformed on a proper basis, Mr. Cole being the first Secretary. On Mr. Cole's retirement Captains O'Brien and Murray together took on the secretaryship, and to their unremitting efforts the present position of the club is almost entirely owing. The ground belonging to the club is a really first-rate one on the high land overlooking the town to the west; there is also a private ground belonging to Government House, to which H.E. the Governor often kindly invites the club. This latter ground is of hard mud and very fast, even faster than that belonging to the Club. The only drawback attaching to it is the dust, which at certain seasons of the year is rather bad, though not worse than is the case on many similar grounds in India. Polo takes place three times a week and chukkas are of very varying quality and quantity. Thus one day not only will most of the best local players be in Nairobi, but some keen players will be passing through on their way to shoot. There will be eight or nine 
chukkas and many of them of good quality. Another week there may be but ten players, and those of the most indifferent or inexperienced kind, and only three or four chukkas may be played. Though not exhilarating to the spectators, the players themselves get at least as much enjoyment out of the game as their more skilled brethren. Many a man who on Monday is the weaker vessel and the butt of his fellow-players finds himself on Friday, on the principle that among the blind the one-eyed is king, a veritable Buckmaster.

There are two regular tournaments held yearly. The Connaught Cup is played for in June or July. This is a contest open for any team in the Protectorate for a cup presented by his Highness the Duke of Connaught, and is the principal event in the year. There is also a handicap tournament in the early months. The club is represented by some very fair teams from time to time. A more than useful one in 1909 consisted of: Capt. Gepp, Capt. O'Brien, Capt. Soames, and Mr. J. Fraser. Possibly the best side that could take the field at the present day would consist of : Major Tuson, the Hon. R. B. Cole, Capt. O'Brien, and Mr. F. Greswolde Williams. Such a side would be up to average regimental form.

Like polo, Hunting is a regular institution in Nairobi, while irregular hunting of a most enjoyable kind is carried on at various centres throughout the Protectorate. The Masara Hounds, the Nairobi pack, owe nearly everything of their present excellence to the unremitting efforts of $\mathrm{Mr}$. James Elkington, and to a slightly lesser degree of Capt. Riddell. Hunting of a sort there has been at Nairobi for many years, and that good sportsman Mr. Goldfinch, a former master of the Hamilton Harriers, used to provide great 
entertainment for all lovers of the chase. When, however, Mr. Elkington and Capt. Riddell, as joint masters, took over the pack in 1908 the hunt was first placed on a definite basis. The old bobbery pack, though eminently serviceable, was dispersed and drafts of first-rate hounds obtained from home, mainly owing to the kindness of Lord Leconfield and Mr. Greswolde Williams. Fine airy stone kennels were built and a suitable stud of hunt horses provided.

The pack is a subscription pack-though it is to be feared that the joint masters have often to dip somewhat deeply into their own pockets-consisting of some fifteen to twenty couples, and hunt twice a week throughout the two seasons, which are formed by the two rainy periods and as long afterwards as the state of ground and scent allow. The usual hour of the meet is 6.30 a.m., at which early hour scent naturally is best, and Sunday morning gives the largest attendance, since it is on that day only that Government servants and business men can regularly afford the time. Jackal and duiker are hunted and provide first-rate sport, perhaps the latter more particularly. The country consists mainly of rolling downs and plains interspersed with cultivation and patches of trees and bush, though occasionally hounds run right into the Ngong forest. A handy pony is the right mount, as there is not a great deal of jumping, but a good deal of clambering up and down dongas and nullahs. He must not be slow, however, as from time to time hounds run uncommonly fast and there are few if any fences to check their speed. The hounds on the whole do fairly well, but naturally require more attention than at home. Tick fever is the great evil with which they have to contend, and a good many valuable hounds 


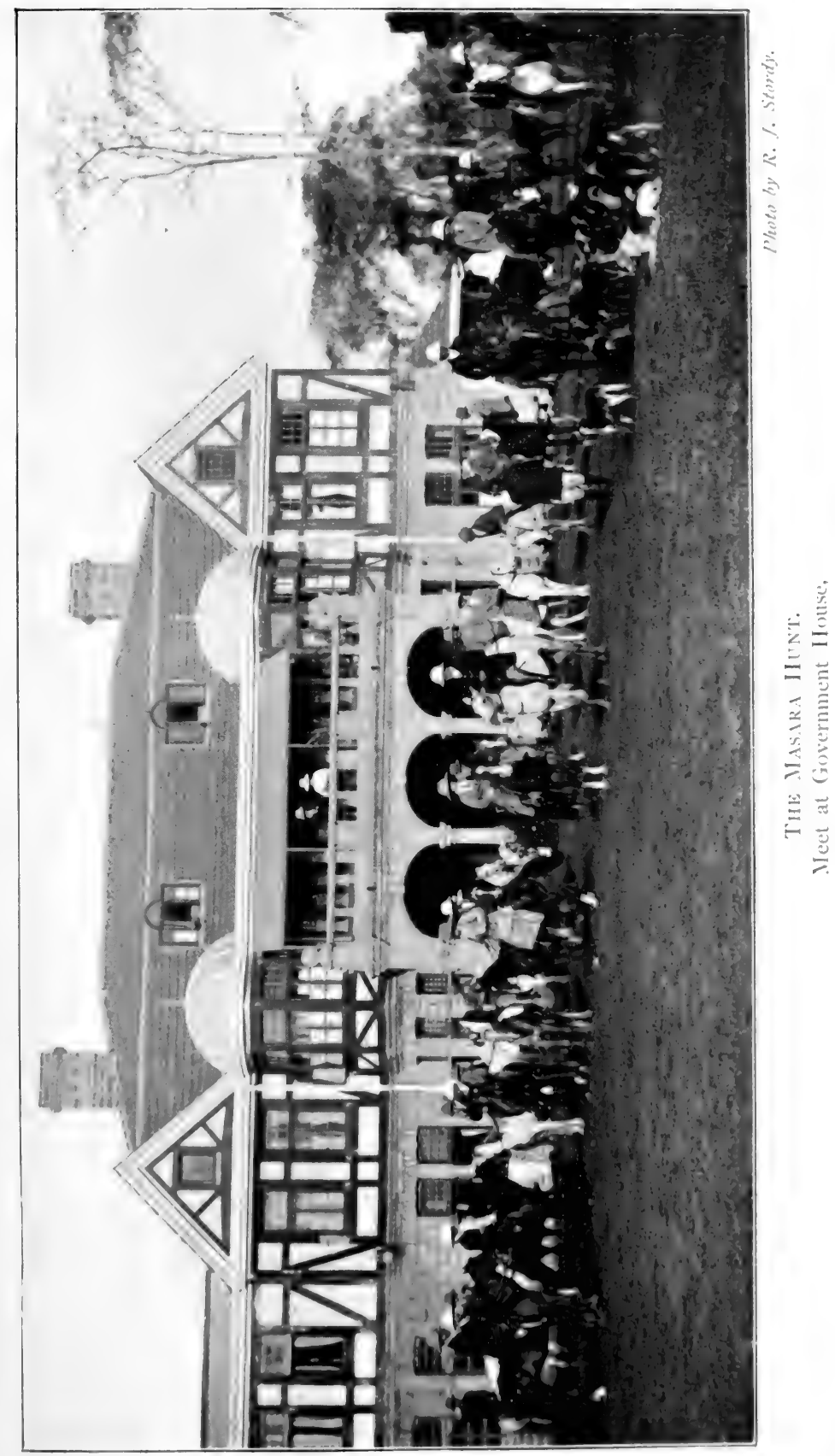



have been lost from this cause. Luckily the Veterinary department is getting master to a certain extent of this curse, and is always ready in the most generous spirit to devote time and attention to the interests of the pack.

In addition to the Masara hounds, there are several packs of irregular constitution which afford the keenest delight to those who follow them, and more especially to those who hunt them. Perhaps chief among such is that of Mr. Goldfinch up at Nakuru, which consists of hounds of his own breeding, mostly $\frac{3}{4}$ or $\frac{7}{8}$ harrier. These hounds have extraordinary scenting powers, powers which their master claims, and to great extent justifies, are not equalled by any imported hounds. Other packs are those owned by Mr. Martin Seth Smith on the Fort Hall road and by Mr. Mervyn Ridley at Makuyu. There is no reason why most large farmers should not keep a few hounds if their inclination lies that way. They are easily housed and fed, and it is not a difficult task to find a fairly efficient native boy to exercise and look after them. They certainly tend to give an added zest to Sunday morning. 


\section{CHAPTER XXXIV}

CRICKET, FOOTBALL, LAWN-TENNIS, GOLF, AND

HOCKEY

WhiLE cricket cannot be said to be extremely popular in the Protectorate, there is a good deal played during the two seasons in the year, that of July to October being the principal. The reason of the comparative unpopularity is simple. In a young country where everyone is hustling for a living at the present and a fortune in the future, it is hard to find time for a game which lasts at least the whole of one day. Still the keen cricketer can be quite sure of a game once a week in the capital. In Nairobi the principal clubs are-The Gymkhana, Parklands, the Railway, and the Indian team, the first-named being usually the strongest, while other clubs are Port Florence, Nakuru and Mombasa, which vary greatly in strength from time to time. The principal match of the year is Officials versus Settlers, taking place during race week, and competition for places in the two teams is very keen.

The wickets are of matting with the outfielding of grass, and this fact, added to the beautiful light, which is almost perfect, being neither dull nor glaring, renders the batsman's task comparatively easy. 
However steady, the ordinary medium pace bowler who relies on his length and an off-break is quite innocuous to batsmen of any real class. His break is diminished and the ball comes along off the matting at such a uniform pace that everything but a real long hop can be played forward to. The most successful bowlers are the really fast, the googly and those who are for ever varying their pace, length, and break. Something, probably the beautiful climate, tends to increase a player's powers, and as in South Africa many returning home after two or three years' absence do so as vastly improved players. The standard of cricket is fairly high, and probably a team selected from the following would be more than a match for most, if not all, second-class counties :

Messrs. Lushington, Pelham Burn, Thomas, A. Lambert, F. O. B. Wilson, H. D. Stanning, Pickwood, Pickering, Kemp, Stone, Long Innes, Jackson, R. Smith, Gower.

All the above are good class bats, with perhaps the first six and Mr. Gower the pick, and Mr. Stone is a most capable wicket-keeper, while Messrs. Thomas, Pickwood, Wilson, Pickering, Jackson, and Lambert would provide an attack of ample variety if somewhat lacking in steadiness.

The Protectorate is one of the few corners of the Empire which has not as yet been visited by any touring team. It would appear that the time has almost come when this omission might be remedied. Although the most popular season for the game is July to October, the months of January, February, and March are almost equally pleasant ; this season would naturally commend itself in preference to the visitors. Possibly the cricket played would be deemed hardly 
worthy of so long a journey, but it might easily be fitted in with a match or two elsewhere and certainly the team could indulge in other sport to their hearts' content. A suggested programme might be:

Ist match $v$. Mombasa at Mombasa.

2nd match $v$. The Gymkhana at Nairobi.

$3 r d$ match $v$. Parklands at Nairobi.

4th match $v$. British East Africa at Nairobi.

$5^{\text {th }}$ match $v$. Nakuru at Nakuru.

6th match $v$. Uganda at Entebbe.

7th match $v$. British East Africa at Nairobi.

The programme over, the tourists would be at liberty to put away the cricket bat and get out the rifle. At this game we could provide men who would teach them in return as much about this sport as they had taught us about cricket.

I have little doubt that the trip would be most enjoyable; one thing can be counted on, and this is a right good welcome!

Football, both with regard to the number of those who play the game and the spectators whom it attracts, easily holds pride of place. There are occasional games of Rugby, but the usual code in practice is Association. There are two competitions-the Dobbie Shield and the Girouard Cup. The former is a League competition, the holders of which, at the moment of writing, are the Parklands F.C. Former holders and competitors include Gymkhana, Caledonians, the Town, Railway and Y.M.C.A. The Girouard Cup is a knock-out competition for a cup presented by the late Governor. In this the competitors in the League Competition are strengthened by the addition of out-country teams such as Londiani, Nakuru, Mombasa, etc. Both competitions 
are fought on the keenest and most modern principles, and if I venture to think that such principles detract a little from the old-time sportsmanship of the game, the fault is most probably with my conservative spirit. At all events there can be no question of the keenness, pluck and energy displayed.

Golf is a modern introduction to the country, and that it has caught on there can be no question. Four years ago the game was unknown to us, now there are at least six courses and an annual championship. It is a game especially suitable to those who are working in the capital. The official or business man usually leaves his work about 4, and has just comfortable time for a cup of tea and a round of golf amid beautiful air and surroundings.

The courses in the Protectorate are Nairobi, Kisumu, Naivasha, Mombasa, Nyeri, and Mweru. Of these Kisumu, Naivasha, and Mombasa are noteworthy as tributes to the perseverance and keenness of the local golfers, and as evidence of the fact that golf is possible, and even enjoyable, under the most unpropitious circumstances. That at Kisumu has a further and most noteworthy distinction. At one time Kisumu or Port Florence had the reputation of being the most unhealthy station in the Protectorate. The thick jungle which surrounded the houses was the haunt and breeding-place of millions of malaria-carrying mosquitos. When Mr. John Ainsworth was appointed Provincial Commissioner of the Nyanza Province, he, with his customary indefatigable energy, started cutting down the surrounding jungle, and though having a horror of the game, in laying out a golf-course in its place chiefly with the idea of keeping down the vegetation. To-day both mosquitos and fever have 
diminished almost to a vanishing point in the station. Alas! Mr. Ainsworth, while gaining so signal a victory over fever, fell a victim himself to the insidious disease of golf, and its devotees now include no firmer adherent. The game itself, therefore, enjoyed a double triumph. The courses at Nyeri and Mweru are at present somewhat rough, and being situated in what are still somewhat unfrequented districts suffer from lack of funds and players. They possess, however, an asset in which they need fear comparison with no course in Africa, their turf. This is of the most splendid description, short, thick, and crisp, and when we add to this the magnificent scenery of mountains, forest, and river amid which they are situated, also the splendid air coming straight from the snows of Kenia, one can have little doubt that not only is their future assured, but that it will be most prosperous.

There remains Nairobi, the principal course in the country, on which the championship is now annually decided. It owed its conception to the energy of the late Mr. Bell, who formed the club and laid out the original course in 1907. Naturally it has been gradually improved from year to year, and its present excellence is undoubtedly due to the great care and perseverance of the present secretary, Mr. A. E. Gardner. It must be confessed that the course represents, as in most African courses, the triumph of the game over natural obstacles. The soil is mostly clay and the grass somewhat sparse and rank; but, as elsewhere, regular play is rapidly improving it, and as year after year it is fed down by sheep the turf gets shorter, crisper, and thicker. The greens are of sand-covered earth, very true but naturally forming a very difficult space on which to remain. (There can be no question 
here as to the merits of run-up or pitch.) It is hoped gradually to replace them by grass. Nothing could be finer than the situation. A bird's-eye view of the town is obtained on one side and the N'gong forest skirts the other, while on a clear day Kilima-njaro to the south-west and Kenia to the east reveal their snowclad peaks. It gives an added thrill to the visitor to know that both lion and leopard still haunt the N'gong forest. Within the last two years an officer in the King's African Rifles came on a party of lions, and was badly mauled, if not, as is usually stated, actually on the course, little more than a long drive distant. There are a few snakes in the long grass and "rough " bounding the course. These form an extra incentive to keeping straight !

The championship of British East Africa was started in 1910 , and the first champion was Mr. A. E. Gardner, the popular secretary of the Nairobi Club. The winner in I9I I was Mr. Figgis, formerly a semi-finalist in the Irish Championship, and other notable players include Messrs. Anderson, Crawley-Boevey, C. Hirtzell, Tanner, and Evans.

Lawn tennis is the game most generally played throughout the Protectorate, as is natural owing to the limited amount of space and time that it demands. Practically every station in the Protectorate has at least one court, and from Mombasa to Port Florence, from Kitui to Moyale the native wonders at the madness of the Englishman and incidentally retrieves his balls. And not only the stations but many of the larger farms are similarly equipped.

The courts are all hard, artificial ones, which if not so pleasant under foot as good springy turf, undoubtedly provide a faster and more scientific game. 
There are a good many tournaments throughout the country, the principal naturally being at Nairobi. The best players in the country are probably Messrs. E. D. Rutherford and G. Lushington, past and present champions.

Hockey, though not so generally popular as football, has a busy season in Nairobi, and there is a League competition for a shield presented by the merchants of the town. The winners in I9I I were the Gymkhana H.C. who were a very fine side and did not lose a game. Probably the standard of play provided by this team was comparatively superior to anything provided by the football clubs. 
APPENDICES 



\section{APPENDIX A.}

\section{Steamer fares to British East Africa.}

\begin{tabular}{|c|c|c|c|}
\hline $\begin{array}{c}\text { Southampton } \\
\text { or } \\
\text { London. }\end{array}$ & to $\begin{array}{c}\text { Kilindini } \\
\text { or } \\
\text { Mombasa. }\end{array}$ & Marseilles & $\begin{array}{l}\text { Kilindini } \\
\text { to } \begin{array}{c}\text { or } \\
\text { Mombasa. }\end{array}\end{array}$ \\
\hline Ist Class. & 2nd Class. & Ist Class. & 2nd Class. \\
\hline$£$ s. d. & $£$ s. d. & $£$ s. d. & $£$ s. d. \\
\hline $\begin{array}{lll}46 & 4 & 0\end{array}$ & $\begin{array}{lll}32 & 6 & 9\end{array}$ & $\begin{array}{lll}40 & 8 & 6\end{array}$ & $\begin{array}{lll}28 & 17 & 6\end{array}$ \\
\hline 46 I5 0 & $\begin{array}{lll}3 I & \text { I } 5 & 0\end{array}$ & $4 \mathrm{I}$ & 2900 \\
\hline
\end{tabular}

3. P. \& O. and British

India S. S. Co. (Tran-

ship at Aden)

$$
\cdots \quad 4^{8} \circ 0 \quad 3000
$$

$\begin{array}{llllll}4 I & 5 & 0 & 28 & 0 & 0\end{array}$

4. Messageries-Maritimes* - $\quad-\quad 4 \quad 4400030$

* From London by rail via Marseilles :-

$$
\begin{array}{llll}
£ 48 & 8 \text { s. } & \ldots & \text { Ist Class. } \\
£ 32 & 45 . & \ldots & \text { 2nd Class. }
\end{array}
$$

\section{Railway Fares :}

London to Marseilles

Ditto with sleeper from $\dddot{P}$ aris to Marseilles...
Ist Class.

$6 \quad 152$

$\begin{array}{lll}8 & \text { I3 } & 4\end{array}$ 2nd Class.

412 II

None.

N.B. - The above Steamer fares are for one berth in an ordinary cabin. Special rates can be quoted for the sole use of a double cabin, a cabin de luxe or a single cabin, should this accommodation be available.

Every information and also tickets by any line can be obtained from Messrs. Newland \& Tarlton, 166, Piccadilly. 


\section{APPENDIX B.}

Rainfall throughout the Protectorate

FOR I9IO-II.

\begin{tabular}{|c|c|c|c|c|c|c|c|c|c|}
\hline \multirow{2}{*}{ Athi river } & \multicolumn{3}{|c|}{ Station. } & \multirow{2}{*}{$\begin{array}{l}\text { Inches. } \\
22 \cdot 16\end{array}$} & \multicolumn{3}{|c|}{ Station. } & \multicolumn{2}{|r|}{ Inches. } \\
\hline & $\ldots$ & & $\ldots$ & & Mazeras Statio & & $\cdots$ & & $37 \cdot 57$ \\
\hline Athi plains ( & Kilim & Mboga) & $\ldots$ & $32 \cdot 53$ & Meru $\quad .$. & $\ldots$ & & & 44.42 \\
\hline Chania (R. F & Hende & on) & ... & $20 \%$ & Molo Station & ... & ... & ... & 63.76 \\
\hline Fort Hall & $\ldots$ & $\ldots$ & $\ldots$ & 39.53 & Mombasa & $\ldots$ & $\ldots$ & $\ldots$ & $37 \cdot 40$ \\
\hline Kericho... & $\ldots$ & $\ldots$ & $\ldots$ & $72 \cdot 81$ & Muhoroni Stat & ion & $\ldots$ & $\ldots$ & $58 \cdot 22$ \\
\hline Kiambu... & $\ldots$ & $\ldots$ & $\ldots$ & $26 \cdot 45$ & Nairobi Statio & & $\ldots$ & $\ldots$ & $28 \cdot 68$ \\
\hline Kibos (Gover & rnmen & Farm) & $\ldots$ & $38 \cdot 77$ & Naivasha Stati & & $\ldots$ & $\ldots$ & IO 39 \\
\hline Kismayu & $\ldots$ & $\ldots$ & $\ldots$ & 18.00 & Nakuru Statior & & $\ldots$ & $\ldots$ & $27 \cdot 21$ \\
\hline Kisumu & $\ldots$ & $\ldots$ & $\ldots$ & 32.71 & Nandi ... & $\ldots$ & $\ldots$ & $\ldots$ & 65.68 \\
\hline Kiu Station & $\ldots$ & $\ldots$ & $\ldots$ & $15 \%$ & Njoro ... & $\ldots$ & $\ldots$ & $\ldots$ & $31 \cdot 12$ \\
\hline Lim & $\ldots$ & $\ldots$ & $\ldots$ & $35 \cdot 66$ & Nyeri ... & $\ldots$ & $\ldots$ & $\ldots$ & 29.43 \\
\hline Londiani & $\ldots$ & & $\ldots$ & $4 I \cdot 54$ & Uasin Guishu & & $\ldots$ & & $52 \cdot 11$ \\
\hline Lumbwa & $\ldots$ & $\ldots$ & $\ldots$ & $52 \cdot 44$ & Uasin Guishu & (Chap & man) & & $28 \cdot 42$ \\
\hline Machakos & $\ldots$ & $\ldots$ & $\ldots$ & 27.45 & Voi Station & ... & $\ldots$ & $\ldots$ & 13.72 \\
\hline Makindu Sta & ation & $\ldots$ & $\ldots$ & 16.20 & & & & & \\
\hline
\end{tabular}

\section{APPENDIX C.}

What ThE SETtLER SHOULD TAKE OUT.

What the settler should take out especially :Saddlery.

Rifles.

Rods and fishing tackle.

Old shooting clothes.

Boots.

What the settler should not especially take out :Everything else. 


\section{APPENDIX D.}

\section{Game Regulations for the Settler.}

\section{A landowner's licence costs $£_{3}$.}

The holder of this licence or his employee may shoot :-

(a) On his own land.

(b) With the leave of the owner or occupier on any private land-anything except :-

(I) Elephant.

(2) Giraffe.

(3) Greater Kudu cow (or bull in the Baringo district).

(4) Cow buffalo.

(5) Neumann's hartebeest.

(6) Eland in certain areas.

(7) Female roan.

(8) Female sable.

(9) Hippopotamus in lakes Naivasha, Nakuru, and Elmenteita.

(IO) Vultures, owls, fish eagles.

A resident's licence costs $£ \mathrm{IO}$.

It enables the licencee to shoot on Government ground:-

\begin{tabular}{|c|c|c|c|c|c|c|c|c|}
\hline \multicolumn{3}{|c|}{ Kind. } & $\begin{array}{l}\text { Number } \\
\text { allowed. }\end{array}$ & \multicolumn{3}{|c|}{ Kind. } & \multicolumn{2}{|r|}{$\begin{array}{l}\text { Number } \\
\text { allowed. }\end{array}$} \\
\hline I. & Bull buffalo & $\cdots$ & 2 & 20. & Thomas' cob & $\ldots$ & $\ldots$ & 4 \\
\hline 2. & Rhinoceros & $\ldots$ & 2 & 21. & Bongo ... & $\ldots$ & $\ldots$ & 2 \\
\hline 3. & Hippopotamus ... & $\ldots$ & 2 & 22. & Impalla ... & $\ldots$ & $\ldots$ & 4 \\
\hline & Eland $\quad \ldots \quad \ldots$ & $\ldots$ & I & 23. & Situtunga... & $\ldots$ & $\ldots$ & 4 \\
\hline & Grevy's zebra & $\ldots$ & 2 & 24. & Wildebeest & $\ldots$ & $\ldots$ & 3 \\
\hline & Common zebra ... & $\ldots$ & 20 & 25. & Grant's gazell & , 4 spec & cies; & \\
\hline & Oryx (Callotis) ... & $\ldots$ & 2 & & of each & $\ldots$ & $\ldots$ & 3 \\
\hline 8. & Oryx (Beisa) $\quad .$. & $\ldots$ & 4 & 26. & Gerenuk ... & & & 4 \\
\hline & $\begin{array}{c}\text { Waterbuck (of } \\
\text { species) }\end{array}$ & each & 2 & & $\begin{array}{l}\text { All species : } \\
\text { dik and ori }\end{array}$ & $\begin{array}{l}\text { uiker, } \\
\text { i ; of } e\end{array}$ & dik- & 10 \\
\hline & Sable antelope bull & $\ldots$ & I & 28. & Suni $\quad \ldots$ & ... & ... & 10 \\
\hline II. & Roan bull $\quad \ldots$ & $\ldots$ & I & 29. & Klipspringer & & $\ldots$ & Io \\
\hline & Greater Kudu bull & $\ldots$ & I & 30. & Ward's reedb & & $\ldots$ & ro \\
\hline 13. & Lesser Kudu $\quad .$. & $\ldots$ & 4 & 3 I. & Chanler's reed & buck & $\ldots$ & 10 \\
\hline 14. & Topi $\quad \ldots$ & $\ldots$ & 2 & 32. & Thomson's ga & elle & $\ldots$ & 10 \\
\hline & Topi (Jubaland, Ta & ana- & & & Peter's gazelle & & ... & 10 \\
\hline & land, Loieta Plains) & & 4 & 34. & Soemmering's & gazelle & $\ldots$ & 10 \\
\hline & Coke's hartebeest & & 20 & 35. & Bushbuck... & ... & $\ldots$ & 10 \\
\hline & Neumann's hartebeest & $\ldots$ & 2 & 36. & Collobus mon & reys & $\ldots$ & 6 \\
\hline & Jackson’s hartebeest & $\ldots$ & 4 & 37. & Marabout stor & ks... & $\ldots$ & 4 \\
\hline 19. & Hunter's antelope & $\ldots$ & 6 & 38. & Egret-each s & oecies & $\ldots$ & 4 \\
\hline
\end{tabular}


A licence to shoot one bull elephant (tusks over $30 \mathrm{lb}$. each) costs £io.

A licence to shoot two bull elephants (tusks over $30 \mathrm{lb}$. each) costs $£ 30$.

\section{APPENDIX E.}

\section{VETERINARY NOTES.}

By R. J. Stordy, Chief Veterinary Officer.

EAST AFRICA, like many new countries, has its fair share of stock diseases. Many of these diseases have been in existence for so long a time that their virulence has become attenuated, with the result that a large percentage of the animals born in the country are possessed of an immunity or resistance to them. The immunity exhibited by the native stock of East Africa is one of the Protectorate's greatest assets, and goes far to ensure the success of the stock raising industry for which large areas of the Protectorate are eminently suited.

To combat disease of stock, an up-to-date Veterinary Department has been formed by the Government, and during the past two years a pathological laboratory has been established for investigating the diseases of the country and for the manufacture of protective sera for the various diseases which affect stock in East Africa.

The chief veterinary officer has his headquarters at Nairobi, and veterinary officers are stationed at various centres throughout the Protectorate.

The veterinary officer at the ports of Mombasa and Kilindini examines all stock entering the Protectorate by sea, and a fly-proof stable is at the disposal of importers of stock at Kilindini in which to house their animals prior to their being entrained for up country. The railway authorities provide fly-proof vehicles for the conveyance of stock through the tsetse-fly belt which extends from the coast to Simba 
station, a distance of 225 miles, and to avoid the heat of the low-lying country, arrangements can be made with the traffic manager to rail stock from Mombasa during the night so that by morning animals. will have reached the cool atmosphere of the uplands.

The Veterinary Department enforces regulations under the authority of the Diseases of Animals Ordinance. The Ordinance demands that all cattle imported into East Africa shall be accompanied by a certificate, certifying that the animals have satisfactorily passed the tuberculin test, and that all horses imported have satisfactorily passed the mallein test for glanders. Dogs, other than those imported from England, Australia, St. Helena, New Zealand, the Azores, and the South African Colonies-Rhodesia excepted-are subject to a quarantine of three months.

The principal diseases affecting cattle are East Coast fever, rinderpest, and contagious pleuro-pneumonia.

East Coast fever is a disease caused by a minute parasite which is transmitted from sick to healthy by certain varieties of ticks. This disease has caused enormous mortality in South Africa, ninety-five per cent. of affected animals having succumbed. Mortality in some districts of East Africa has been considerable. Scientific investigation has proved, however, that the disease has been in existence for a number of years in various parts of the Protectorate, and that the native animal in these districts exhibits an immunity to the disease. In the Nairobi-Kyambu district, the mortality from this disease during the years 1907-8 was very high, and stringent quarantine regulations were imposed. Many of these restrictions have been either removed or greatly relaxed, and with the fencing of the dairy farms in the district and the introduction of Theiler's method of immunisation, it is hoped that in the near future it will be possible to facilitate the movement of cattle by raising the restrictions now imposed.

There are still many parts of the Protectorate which are free from East Coast fever, and it is the endeavour of the Veterinary Department to keep clean non-infected pasture 
lands. The removal of the Akikuyu and the Masai tribes, with their flocks and herds, into reservations will do much to prevent the spread of not only East Coast fever but other contagious diseases of stock. In all infected East Coast fever districts, farmers take great risks in running imported animals ; for they are highly susceptible to East Coast fever and the mortality among them is extremely high. There is, however, a wide field open to the farmers of East Africa in building up good native herds by judicious selection and systematic breeding.

Rinderpest has been very prevalent during the past two years in East Africa. The disease spread rapidly through the Masai herds on Laikipia and caused very heavy mortality among the cattle in the Kavirondo district. Large quantities of anti-rinderpest serum were produced at the veterinary laboratory near Nairobi, and its use has done much to suppress disease and prevent its spread. The disease in many districts is fast dying out, and with the exception of a small outbreak in the Nandi district, no new manifestations of the disease have been recorded.

The Veterinary Department has several thousand doses of serum in hand should further outbreaks occur.

Contagious Pleuro-Pneumonia.-In recent outbreaks the mortality from this disease has not been large. The old "lunger" makes the disease particularly difficult to eradicate, and there can be no doubt that there are many old lungers among the native herds. Tail inoculation has been carried out where the disease had appeared, but in some cases the results have not been satisfactory. The inoculation has the advantage of curtailing the course of the disease by shortening the period of incubation.

Texas Fever (Redwater).-This disease is fairly prevalent throughout the Protectorate. Mortality among native stock is small. Animals when young pass through an attack of the disease which confers an immunity. In animals imported from tick-free countries, the mortality has been high, but since the introduction of a system of inoculation, whereby an animal is made to pass through a mild attack of the disease, 
the loss among susceptible stock has been greatly reduced. All farmers importing cattle from England or other countries or districts where Texas fever is unknown should have their cattle immunised before sending them to the Protectorate.

The Chief Veterinary Officer of the Board of Agriculture, Mr. Stewart Stockman, is pleased at all times to give every assistance in this matter. There is no tuberculosis among East African cattle.

The principal diseases of sheep are sheep pox and scabies. Sheep pox, which is so fatal a disease in most countries, has become within recent years a benign disease in East Africa, due to the fact that the virus of the disease has become attenuated by its passage through successive generations of native sheep.

Vaccine is prepared at the Veterinary Laboratory for the vaccination of sheep.

Scabies is prevalent among the native flocks, and although the parasite of this disease does not do much damage to the hairy native sheep, its ravages among wool sheep are too well known to require repetition here. The dipping of trade sheep passing up and down the country at the Government dipping stations, the erection of private dipping plant on many of the sheep farms, and the removal of the native flocks to reserves, will materially assist the authorities in their endeavours to suppress the disease. Scabies is a great menace to the wool industry of any country, and the hearty co-operation of all sheep farmers in East Africa is necessary to enable everyone to keep their own and their neighbours' flocks clean.

Foot rot is found in some parts of the Protectorate, and Wostril Fly and Wire Worm require the careful attention of the flock master.

Horse sickness and contagious lymphangitis are the most important diseases of horses. Occasional cases of horse sickness occur annually, but no very bad season of this disease has been experienced since 1904 .

The better built stable, with its mosquito-proof windows and doors, careful stable management, and an increased intelligence on the part of the native syce, have done much to 
reduce the number of outbreaks. Horse owners should take the greatest care to smear their animals over with a little kerosene oil when using their animals after sunset. Theiler has met with great success in his immunisation of mules from this disease, and it is sincerely hoped that his endeavours to immunise horses will be crowned with success.

The Veterinary Department have been most active in their endeavours to suppress contagious lymphangitis, and have established a quarantine station for the reception of infected animals. The disease runs a slow course and does not yield readily to treatment. There is no glanders in East Africa.

A great menace to the pig industry of the country is a peculiar virulent form of swine fever. For some time past this disease has been under investigation and every endeavour is now being made to produce a serum with which to protect swine. Pigs do exceedingly well in East Africa, and probably there is no place in the world in which they can be reared so cheaply, for there is not only a good natural feed for them throughout the year, but grain is cheap and easily obtained.

Ostrich farming is advancing rapidly, but, as in South Africa, the greatest care must be taken of young birds, for in some districts of the Protectorate the Strongylus douglassi has been the cause of considerable mortality.

The death rate among imported dogs from tick fever ran to close on eighty-four per cent. With the discovery of the trypanblue treatment, by Nuttall, of Cambridge, this death rate has been reduced to about twenty per cent. Tubes of sterilised trypanblue can be obtained from the veterinary authorities, and all classes of dogs can now be imported without the grave risk which dog owners had to run before the introduction of this treatment. No case of rabies has been recorded in the Protectorate.

From time to time the veterinarians publish articles on the various diseases of stock either in the Agricultural Journal or in leaflet form, and it is proposed to arrange a course of lectures for farmers. 


\section{INDEX}

A

Aberdare mountains, 320

Absence of minerals, 5

Abyssinians, the, 210

Agricultural prospects, $104 \mathrm{et}$ seq.

Ainsworth, Mr. John, 27, 339, 340

Amala river, 254

Amalgamation between British East

Africa and Uganda, possibility of, 6

Anderson, Mr., 123, 341

Angling possibilities untouched, 318

Animals beyond the pale, 246

of the Back Blocks, 282

that provide meat or hides, 265 et seq.

Animals which provide $\triangleleft$ sport :

buffalo, 255

bushbuck, 260

Chanler's reedbuck, 263

cheetah, 259

duiker, 263

impala, 262

klipspringer, 263

leopard, 258

lesser Kudu, 26I

lion, 248

steinbok, 263

wart-hog, 262

Anti-rinderpest serum, $35^{\circ}$

Archer, Mr., 306

Area of farms, 98

Assets of Highlands, 4

Athi plains, 200, 254, 268, 269, 272

Atkinson, Mr., $15^{8}$

\section{B}

Baboon, 28I

Bahamas, 1 I 3

Barbel, 321
Baringo, Lake, 279

Big Game shooting, 231 et seq.

best routes for, 233

danger of, 239

Bird-shooting, dog essential for, 306

Black wattle, 115,120

drying and preparation of bark, II 9

suitable site for growing, 118

Blood poisoning through lion bites or scratches, remedy for, 254

Bobs, rust-resistant, 122

Boers, influx of, 82 ; a difficult pro. blem, 83

Bongo, 285

Boy Scouts, 21 3

Brandt, Mr. D. R., I 38

British Central Africa, 237

British East Africa, a game reserve for lions, 1

and Uganda, possibility of amalgam ation between, 6

its possibilities of colonisation, 2

most peculiar of his Majesty's Dominions, I

British East African Protectorate, extension of, I

Buffalo, 255 ; responsible for presence of tsetse-fly, 257

Burn, Mr. Pelham, 337

Bushbuck, 260

Bush-pig, 28I

Bustard, 303

Buxton, Mr. Edward North, 265, 269

C

Cardross, Lord, 33 I

Cattle, 134

diseases of, 137-139 
Cattle, list of pure bred imported animals, I 35

principal diseases affecting, 349

starting a herd, 136

Changamwe, I99

Chanler's reedbuck, 263

Cheetah, 259

Children, health and climate with regard to, 91

Climate and health, Io

Clutterbuck, Mr. C. B., 33 I

Coarse fish, tackle for, 323

Coffee growing, 126

disease non-existent, 129

picking and pulping, I 29

preparation of land for, 128

selection of land for, 127

Cole, the Hon. Mr. Berkeley, 43, 286, $328,33 \mathrm{I}-333$

Cole, the Hon. Mr. Galbraith, 43, 58 deportation of, 56

Colonial Office, difficulties of getting satisfactory answers from, 3, 4

Colonisation, possibilities of, 2

Colonists' Association, the, 218

Communication in the Protectorate, 5

Contagious pleuro-pneumonia, 350

Convention of Associations, 2 I 9

Cranworth, Lady, gives advice to women in British East Africa, 84 et seq.

Crawley-Boevey, Mr., 34I

Cricket, 336

selected team, 337

suggested programme, $33^{8}$

wicket of matting, 336

Crocodile, 297

Crops, seasonal and permanent, I06-I 1o

\section{D}

Death rate, I 8

Defassa, 267

Delamere, Lord, 43, 80, 105, I21, I34, 1 58, 2 1 $8,219,231,251,286,287$, 295, 33I

Dipping of sheep, 35I

Disease, inoculation for, 350

Diseases, 14 et seq.

affecting cattle, principal, 349

of cattle, 137-1 39

of sheep, I 52

stock, 348

Dog, essential for bird-shooting, 306

Dogs, subject to quarantine, 349

Domestic servants, native, 87,88

Drawbacks, 5
Duerdon, Prof. T. E., 139

Dugmore, Mr., 277, 295

Duiker, 263

Duke of Connaught's cup for polo, 333

\section{E}

East Africa, a generation ago, not even a name, $I$

East African Rifles, formation of, 208

East African Turf Club, the, 331

East Coast fever, 349

Eastwood, Mr., 33I

Education, 222 et seq.

cost of, 223

elementary, 225

Europeans and, 226

Mr. R. J. Orr director of, 223

problem, the Eurasian, 225

Educational facilities, lack of, 5

Eland, 265

Elephant, 282

localities where found, 284

Elgon slopes, 286

Eliot, Sir Charles, 33, 36, 194

resigns office, 37,38

Elkington, Mr. James, 333, 334

Ellipsiprymnus, 267

Embu, 30

Establishment for man and wife, 89

Eurasian education problem, the, 225

Eurasians and Indians, schools for, 224,226

European Board School, 224

Europeans and education, 226

Evans, Mr. G. W., 123, 34 I

F

Farms, area of, 98

Fauna likely to provide sport, list of, 245

"Fauna, The," society for the preservation of the fauna, 3I 5

Fever, East Coast, 349

swine, virulent form of, $35^{2}$

Figgis, Mr., 34I

Fishing, 318 et seq. tackle, 323

Fleischman, Mr., 297

Football, 338

Foot-rot, 35I

Forests, I 55 et seq.

Fort Hall, 49, I 16, I 76, I97 Road, 95 
Francolin, 303

Fraser, Mr. J., 333

Freuen, Mr. Moreton, 160

Fringe-eared Oryx (Callotis), 291

Frontiersmen, Legion of, 213

Fruit, seasonal, 107

\section{G}

Game animals of the Protectorate, $24 \mathrm{I}$ et seq.

list of, 242,243

Game birds for sport and for the pot, 298 et seq.

Game, inroads made by, 314

Game licence, cost of, 347

Game Regulations, 347

Game Reserves, 308 et seq.

Northern, 31 I

object of, 315

Gardening in East Africa, 89

Gardner, Mr. A. E., 340, 341

Gazella granti brightii, 272

Garella granti notata, 272

Gazella granti typica, 272

Gepp, Capt., 333

Gerenuk, 29I

German East Africa, I1 2, I13, I17, $236,269,280$

German East Africa, Sendeu selected as Chief of, 35

Giant hog, 295

Giraffe, 292

Girouard, Sir Percy, 6, 40, 193, 215 resigns Governorship, $215 n$.

Glanders, non-existent in East Africa, $35^{2}$

Gluyas, 122

Goldfinch, Mr., 333, 335

Golf, 339

Governor, 216

Gower, Mr., 337

Grant, Mr., $15^{8}$

Grant's gazelle, 272

Greater Kudu, 288

Grevy's zebra, 294

Grogan, Mr., 320

Guaso Narok, 38

Guaso Nyero river, 235

Guinea fowl, 305

"Gu-gu," the, 244

Guns, best for lions, 253

\section{$\mathbf{H}$}

Harcourt, Rt. Hon. Mr., deports the Hon. Mr. Galbraith Cole, 56 ; $5^{8}$
Hartebeeste, 269

Harvey, Sir Robert, 231, 259

Health and climate, 1o et seq. with regard to children, 9I

Herz, Mr. A. E., 178

Hides, animals that provide, 265

Highlands, assets of, 4

Hill, Brothers, 25I

Hill, Mr. J. K., I5I

Hinde, Mr. S. L., 320

Hints for a woman in British East Africa, $84 \mathrm{et} \mathrm{seq.}$

Hippopotamus, 280

Hirtzell, Mr. C., 34I

Hockey, 342

Horse racing, hunting and polo, 324 et seq.

Horse, types of, 327

Horse-sickness, 351 precautions against, 326

Hospitality of officials, 79

Hounds and tick fever, 334

How to keep fit, 19, 20

Humphrey, Mr., 78

Hunter, Mr., 231

Hunter's Antelope, 294

Hunting, 333

Hutchins, Mr. D. E., I16, 157, 159, 163

Hyæna, 296

I

Immigrants, variety of, 8I

Immunisation, Theiler's method of, $\mathbf{3 4 9}$

Imperial British East Africa Company, 208

Indian population, the, 6o et seq. origin of, 62

introduce burrowing flea, 64

Indians and Eurasians, schools for, 224, 226

Industries taught in prisons, 207

Infected animals, quarantine station for, $35^{2}$

Innes, Mr. Long, 337

Inoculation for disease, 350

Insect pests of wheat, 123

Insects and other plagues, seriousness of, 5

Ithanga hills, 263

\section{J}

Jackson, Mr. F. J., 34, 231, 266, 285, 294, 301, 320, 337

Jackson, Mr. W. B., II 7

"Jigger," burrowing flea, due to Indian, 64 
Jones, Mr. "Buffalo," 27I

Jorkins, Mr., I6I

Jubaland, 27 I

\section{K}

Kamasai tribe, 29

Kapiti plains, 254, 268, 269, 272

Karimojo sheep, I49

Kavirondo, the, 25 et seq.

Bantu, 26

Kedong valley, 83, 235, 272

Kemp, Mr., 337

Kenani river, 26I

Kenia forest, the, most valuable in the Protectorate, 159

Mount, 34

principal timbers in, 161 ; 295

West, 21, I47; province, 22, 197

Kiambu district, 8 I

Kikuyu, the, 24, 25, 45 et seq. ; 170 escarpment, 201, 267

Kilindini, 1 26, 198

King's African Rifles, the, 205, 207 history of, 208

strength of, 209; personnel, 209 ; conditions of service and rates of pay, 210,212

Kipigori, 29

Kisii, 284

Kitui district, 30 river, 279,285

Klipspringer, 263

Kyambu, 21, I 16

\section{L}

Labour, 165 et seq.

demand for, not regular, I68

plentiful and intelligent, 4

Lack of educational facilities, 5

Lake Baringo, 272

Rudolf, 27I, 280

Lambert, Mr. A., 337

Lament, a bitter and sarcastic, 144

Land and the land laws, 93 et seq.

annual rent of, 96

conditions for obtaining, 95

obtaining by fraudulent means, 98

speculator, unpopularity of, 80

surveyors, 102

surveyors, increase of desirable, 102

Landowners' Association, 220

Landowner's licence, cost of, 347

Lawn tennis, 34I

Leconfield, Lord, 334
Lectures for farmers, proposed course of, $35^{2}$

Legalishu, Masai Chief, 4I

Legion of Frontiersmen, 213

Legislative Council, 217

Lemmik plains, I4I, 235

Lenana, chief of the Masai, 35, 40 death of, $4 \mathrm{I}$

Leopard, $25^{8}$

first killed in British East Africa by Sir R. Harvey, 259

Lesser Kudu, 260, 26I

Levy, Mr. W. H., 178

Licence, game, cost of, 347

Likipia, 21, 38, 235, 272

Limoru, 1 16, 201

district, $8 \mathbf{I}$

Lingham and Grogan, Messrs., forests leased to, 158

Lion, the, 248

best guns for, 253

bites or scratches, remedy for, 254

size of, 253

tracking of, 251

List of fauna likely to provide sport, 245

of game animals, 242, 243

of pure bred animals, 135

I ivestock, 107

Local politics, 215 et seq:

Loieta plains, 39, 40, 141 , 269, 27 I

Londiani, 29, I I6, 202, 27I, 274

Lorian swamp, 262

Lumbwa, 2, 5, 202, 203

Lushington, Mr., 337, 342

Lymphangitis, endeavours to suppress, $35^{2}$

Lynx, 295

\section{M}

Macdonald, Mr. A. C., 126

McMillan, Mr., 268

Magadi, Lake, 177

Maize growing, 124

average crop, 125

local demand for, 125

Man and wife, establishment for, 89

Marsabit, Lake, 236, 254, 279, 284

Masai, the, 25, 33 et seq.

a nomad people, 35

average height of, 42

bravery of, 43,210

visited by famine, 34

Masara Hounds, 264, 333

Mau escarpment, the, $2 \mathrm{I}, 83$

forests, the, 157 
Maungu, 199

Mazeras, I99, 289

Mbatian, chief of the Masai, 34

Medical staff, I9, 9 I

Meru, 30

Military and Police Forces, 204 et seq. expenditure, 207

Minerals, 174 et seq. absence of, 5

Mission-educated natives untrustworthy, 229

Mohoroni, 284

Molo, 202

Mombasa, 134, 177, 197, 207

Montgomerie, Mr. E. R., I39

M'toto Andei, 26I

Muhoroni, 295

Mumias, 197

Mumoni, abandoned station, 31 hills, 285,289

Murray, Capt. J., 289, 332

\section{$\mathbf{N}$}

Naircbi, 90, 91, 108, 176, 178, 197, $200,207,211,223,224,324$

European hospital at, 19

Naivasha province, 22

Lake, $81,93,237,280$

Nakuru, 81, 202, 280

Nandi, the, 29, 30 escarpment, 21, 29, 210

Natal, 116, I17, 119

Native servants, 87,88

Natron, Lake, 172, 257, 295

N'darugu river, 116,176

Neumann, the late Mr., 283

Newland, Mr. V. M., 178

Ngoma, dancing ceremony, 49

N'gong mountains, 38 forest, $\mathbf{2 8 2}$

Njoro, 81, 116, 203, 263

North Guaso Nyero river, 254, 262, 279,294

Northern Game Reserve, inmates of, 3II

Nuttall, Mr., discoverer of trypanblue treatment for tick fever, $35^{2}$

Nyanza basin, 22

Nzoia river, 197, 268

\section{$\mathrm{O}$}

O'Brien, Capt., 332, 333

Officials, salaries of, insufficient, 78 , 79

hospitality of, 79
Orr, Mr. R. J., director of Education, 223

Oryx beisa, 290

Ostrich farming, 352

Ostriches, 139

area and how to start a farm, 14I

enemies of, 142

incubation of eggs, 142

Prof. T. E. Duerdon on, 139

rearing, etc., of birds, 142

Outfit for women, useful, 86,87

\section{$\mathbf{P}$}

"Penitent Butchers, The," 315

Percival, Mr. A. B., 25I, 317

Percival, Mr. Philip, 293

Peter's gazelle, 294

Pickering, Mr., 337

Pigeon, 301

Pigs, I3o

best varieties, I31

immune from disease, 133

pens and styes, 132

Plagues, insect and other, seriousness of, 5

Pleuro-pneumonia, contagious, 350

Police force, the, 204

cost of, $2 \mathrm{c} 6$

petty crimes in, 205

Polo, 33I

Duke of Connaught's cup for, 333

Population, heterogeneous, 21 et seq.

Port Florence, 203

Poultry farming, 89

Precautions against horse-sickness, 326

Price, Mr., 152

Prisons, 206

industries taught in, 207

Programme for a race meeting, 329

Prosser, Mr. E. J., I3I

\section{Q}

Quail, 305

Quarantine, dogs subject to, 349 station for infected animals, $35^{2}$

$\mathrm{R}$

Rabies unknown in Protectorate, 352

Race meetings, 324

sample programme for a two days', 329

Races and classes, 2I et seq. 
Rainfall throughout the Protectorate for 1910-11, 346 variation of, 109

Raptorial fishes, 322

"Rat Killers' Association," the, 219

Redwater (Texas fever), $35^{\circ}$

Reedbuck, 295

Regulations, game, 347

Reichenow's guinea fowl, 305

Remedy for lion bites or scratches, 254

Rent, revisal of, 99-10I

Resident's licence, cost of, 347

Revisal of rent, 99-10I

Rhinoceros, 275

Rhodesia, 169

Riddell, Capt., 178, 333, 334

Ridley, Mr. Mervyn, 268, 335

Rietti, rust-resistant, 122

Rifles recommended, 247

Rift valley, 201, 237, 269

Rinderpest, $35^{\circ}$

Roan antelope, 290

Roosevelt, ex-President, 91, 236, 287

Roosevelt, Mr. Kermit, 287

Routledge, Mr., 50

Rumuruti, 273

Rutherford, Mr. E. D., 342

See also Swift

Sable antelope, 289

Sadler, Sir James, 77

Salaries of officials insufficient, 78 , 79

Samuel, Messrs. M. and Co., 178

Sand grouse, 299

Scabies, 35I

Schillings, Mr., 296

Sea-fish, tackle for, 323

Seasonal crops, 106-1 10 fruit, 107

Sendeu, chief of German East Africa, 35

Serengati plains, 266, 272

Serum, anti-rinderpest, 350

Servants, native, 87,88

Settler, what he should take out, 346

Settlers and Officials, 75 et seq.

struggles between, 77

white, first arrival of, 35

Sheep, earliest experiments in farming, 147

diseases of, 152

suitable types, 149
Sheep-farmer, educational stage of 152

Sheep-pox, 351

Shelford, Capt., 178

Shimba hills, 262,289

Simba, 198

Sisal, Ltd., 173

Sisal hemp, III-I 15

suitable area for growing, 112

washing and decortication of fibre, II 4

Situtunga, 293

Smith, Mr. D. Seth, 268

Smith, Mr. Martin Seth, 335

Smith, Mr. R., 337

Snipe, 302

Soames, Capt., 333

Soda, crystalline, a valuable mineral, 178

Soemmerring's gazelle, 294

Solai, Lake, 269

Somali and Swahili, the, 66 et seq.

Sotik plains, the, 25, 141

Soudanese and the King's African Rifles, 209

fighting qualities of, 209

women, villainous temper of, 209

South Guaso Nyero river, 254, 256, 257,279

Southern Game Reserve, 312

a national asset, 3I4

inmates of, 3I 3

Speke's Tragelaphus, 293

Sporting dogs and ticks, 307

Stanning, Mr. H. D., 337

Steamer fares to British East Africa, 345

Steinbok, 263

Stewart, Sir Donald, 36, 38, 306

Stigand, Mr., 272, 275, 283, 286, 295

Stock diseases, 348

Stockman, Mr. Stewart, 35I

Stone, Mr., 337

Stordy, Mr. R. J., 306, 348

Strongylus douglassi, cause of mortality in ostriches, 352

Struggles between settlers and officials, 77

Suk, tribe, 30

valley, 149

Sultan Hamoud, 198

Surveyors, land, increase of desirable, 102

Swahili, 2 ro

and Somali, the, 66 et seq.

Swift, Mr. T. R., I 7 I

Swift and Rutherford, Messrs., 173

Swine fever, virulent form of, 352 


\section{$\mathrm{T}$}

Tana river, $254,261,279,280$

Tanner, Mr., 34 I

Tarlton, Mr. H., 33 I

Teachers, limited supply of, 229

Team, cricket, a selected, 337

Texas Fever (Redwater), $35^{\circ}$

The Black List, 275 et seq.

Theiler's method of immunisation, 349

Thika river, 254, 279

Thomas, Mr., 337

Thomas' kob, 294

Thompson's Falls, 284

Thomson's gazelle, 273

Tick fever, 334 trypanblue treatment for, 352

Ticks and sporting dogs, 307

Timber, principal variety of in Kenia forest, I6I

Topi, 27 I

Tracking up lions, $25 \mathrm{I}$

Transvaal, 1 16, I17, 125

Trobridge, Mr. A., I 78

Trout, possibility of acclimatising, 319

Trout-fishing in British East Africa, 319

Trypanblue treatment for tick fever, 352

Tsavo river, 26r, 285

Tsetse-fly, the, buffalo responsible for introduction of, 257

Tuberculosis, none among East African cattle, $35^{\mathrm{I}}$

Turkhana sheep, I49

tribe, 30

Turner, Mr., 224

Tuson, Major, 333

Type of settler required, I8o et seq.

Uasin Guishu plateau, 21, 29, 82, 83, I70, 197, 202, 263, 268, 274, 295

hinterland, 147, 235

Uganda, 127, I66, 236, 237, 268

and British East Africa, possibility of amalgamation, 6

kob, 294

Railway, the, 192 et seq.
Ukamba province, 22

Ulu, 200

\section{V}

Variation of rainfall, Iog

Veterinary department formed by Government, 348

notes, 348

Victoria, Lake, 203, 280

Victoria Nyanza, Lake, 26, 94

Voi river, I97, 26I

Volunteer movement, 2 I 3

W

Wa-Kamba, 24, 30 et seq.

Wakamba tribe, the, precocious, 2 I 2

Wa-Kikuyu, the, 24

Waller's gazelle, 29I

Ward, Mr. H. F., 178, 33I

Warwick, Lord, Kenia forest leased to, 160

Waterbuck, 267

What the settler should take out, 346

Wheat, chief growing centre of, $12 x$ insect pests of, 123

White-bearded brindled gnu, 268

White settlers, first arrival of, 35

Wickets, matting, 336

Wildbeeste, 268

Wild dogs, 295

Wildfowl, 306

Williams, Mr. F. Greswolde, 331, 333, 334

Willoughby, Sir John, 23 I

Wilson, Mr. F. O. B., 337

Wire worm, 35

Wodehouse, Lord, 257

Women in British East Africa, hints for, 84 et seq.

useful outfit for, 86,87

Woosnam, Mr. R. B., 317, 321, 322

Wostril fly, 35I

$\mathbf{Y}$

Yatta plains, I 4I, 254, 266, 279

Yucatan, 113

Zebra, 279

\section{Z}


Richard Clay and Sons, Limited,

BRUNSWICK STREET, STAMFORD STREET, S. E., AND BUNGAY, SUFFOLK. 


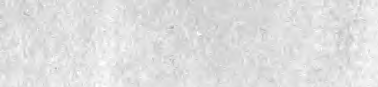

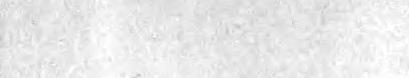




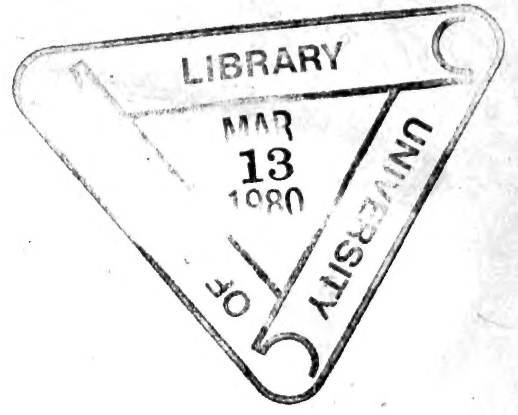




\section{PLEASE DO NOT REMOVE CARDS OR SLIPS FROM THIS POCKET}

\section{UNIVERSITY OF TORONTO LIBRARY}

DT

425

C88
Cranworth, Bertram Francis Gurdon, 2d baron A colony in the making 


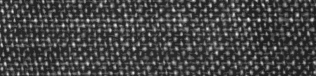

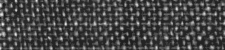

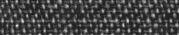

$+4$

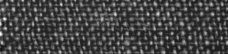

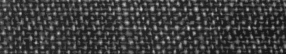

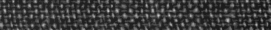

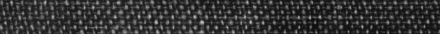

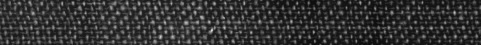

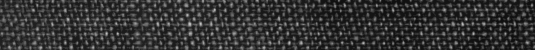

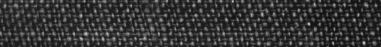

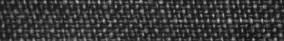

to

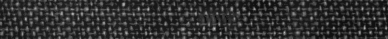

P P

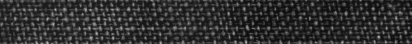

